\title{
Számítógéppel segített felfedeztetés-központú matematikaoktatás
}

\author{
Doktori értekezés
}

\author{
MÁder AtTila
}

Témavezetô:

Dr. KosztolÁnYi JózSEF

egyetemi docens

Matematika- és Számítástudományok Doktori Iskola

Szegedi Tudományegyetem

Természettudományi és Informatikai Kar

Bolyai Intézet 
„A matematika a természettudományok közeli rokona, a „kísérletezó tudományok" egyik típusa. A matematikában is eredményre vezethet megfigyelés és analógia. ... A jövố középiskoláiban - remélem - nem hanyagolják majd el annyira a matematikai felfedezés, a tudományos módszer és indukció szempontjait, mint a mai középiskolában." (PÓlYA GYÖRGY) 


\section{Tartalomjegyzék}

1. Bevezetés 1

1.1. Komplex matematikatanítási kísérlet . . . . . . . . . . . . . . 1

1.2. A magyar matematikaoktatás a nemzetközi mérések tükrében . . . . . 2

1.2.1. TIMSS . . . . . . . . . . . . . . . . 3

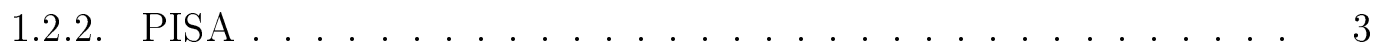

1.2.3. A TIMSS és PISA mérések eredményeinek összehasonlítása . . . 5

1.3. A kompetencia fogalma és szerepe az oktatásban . . . . . . . . . . . . . 6

1.3.1. A kompetencia fogalma . . . . . . . . . . . . . . . . . 6

1.3.2. A matematikai kompetencia . . . . . . . . . . . . . 8

1.3.3. Az Országos kompetenciamérés . . . . . . . . . . . . . . . . 9

1.4. Kiutak keresése: modellezés és valóságközeli matematika . . . . . . . 10

1.4.1. Matematikai modellezés . . . . . . . . . . . . . . . . . . 10

1.4.2. Valóságközeli vagy realisztikus matematika . . . . . . . . . . 12

1.5. A jelen helyzet és a jövő társadalmának elvárásai . . . . . . . . . . . 13

1.6. Összefoglalás . . . . . . . . . . . . . . . . . . . . 16

2. Felfedezések a matematikában $\quad 18$

2.1. Bevezetés . . . . . . . . . . . . . . . . . . . . . . . 18

2.2. Experimental Mathematics . . . . . . . . . . . . . . . . . 18

2.2.1. Kísérleti matematika . . . . . . . . . . . . . . . . 18

2.2.2. Rövid történeti áttekintés . . . . . . . . . . . . . . . . 20

2.3. A kísérleti matematika alkalmazása az oktatásban . . . . . . . . . . . . 22

2.3.1. Kísérletek és matematika . . . . . . . . . . . . . . . . . . . . 22

2.3.2. A jelenlegi helyzet áttekintése: a bizonyítások súlya a matematika érettségi vizsgán . . . . . . . . . . . . . . . 26 
2.3.3. Kísérletek és bizonyítások . . . . . . . . . . . . . . 26

3. Felfedezések a matematikaórán $\quad 29$

3.1. Felfedezések számítógép nélkül . . . . . . . . . . . . . . . . . . 30

3.1.1. Múveleti tulajdonságok . . . . . . . . . . . . . . . . . 30

3.1.2. Nevezetes azonosságok - egy példa . . . . . . . . . . . . . . 31

3.1.3. Nevezetes összegek - egy példa . . . . . . . . . . . . . . . . 32

3.1.4. Felfedezések a geometriában - mérés és szerkesztés . . . . . . . . 33

3.1.5. A háromszög belsố szögeinek összege I. . . . . . . . . . . . . . . 34

3.1.6. A háromszög belsô szögeinek összege II. . . . . . . . . . . . . . 35

3.1.7. A háromszög belsố szögeinek összege III. . . . . . . . . . . . . . 36

3.1.8. A Thalész-tétel . . . . . . . . . . . . . . . . . 37

3.1.9. Egy valószínúségi modell . . . . . . . . . . . . . . . . . 38

3.1.10. Módszertani összefoglaló . . . . . . . . . . . . . . . . . . . . . 39

3.2. A tanár megváltozott szerepe . . . . . . . . . . . . . . . . . . 40

3.2.1. IKT - Infokommunikációs technológiák az oktatásban . . . . . . 40

3.2.2. Digitális bennszülöttek és digitális bevándorlók . . . . . . . . . 42

3.2.3. E-learning . . . . . . . . . . . . . . . . . . 43

3.2.4. A tanár új szerepe . . . . . . . . . . . . . . . . . . . 44

3.3. Felfedezések a számítógép eszközszintû felhasználásával . . . . . . . . . 46

3.3.1. Bevezetés . . . . . . . . . . . . . . 4 46

3.3.2. Nevezetes összegek - egy példa ismét . . . . . . . . . . . . . 47

3.3.3. Halmazmúveletek tulajdonságai, halmazelméleti azonosságok . . 48

3.3.4. A háromszög belsô szögeinek összege IV . . . . . . . . . . . . . . 49

3.3.5. A Monty Hall-dilemma - a számítógép és az intuíció . . . . . . . 50

3.3.6. A lusta pénztáros - a számítógép és a sejtés . . . . . . . . . . 52

3.3.7. Módszertani összefoglaló . . . . . . . . . . . . . . . . . . 54

3.4. Felfedezések a számítógép alkotó jellegú felhasználásával . . . . . . . 54

3.4.1. Bevezetés . . . . . . . . . . . . . . . . . . 54

3.4.2. Komputer-algebrai rendszerek (CAS) . . . . . . . . . . 54

3.4.3. Szoftverek az oktatás szolgálatában . . . . . . . . . . . 55

3.4.4. A Thalész-tétel . . . . . . . . . . . . . . . . . 59

3.4.5. Trigonometrikus azonosságok . . . . . . . . . . . . 60 
3.4.6. Szintetikus geometria . . . . . . . . . . . . 61

3.4.7. Az integrál és a grafikon alatti terület . . . . . . . . . . . . 64

3.4.8. Honnan tudja a számológép, mennyi $\cos 30^{\circ}$ ? . . . . . . . . . . 66

3.4.9. Módszertani összefoglaló . . . . . . . . . . . . . . . . . . . 69

$\begin{array}{ll}\text { 4. Szigetek } & 70\end{array}$

4.1. Bevezetés . . . . . . . . . . . . . . . . . . 70

4.2. Történeti áttekintés . . . . . . . . . . . . . . . . . . . 70

4.3. A sziget fogalmának kialakítása . . . . . . . . . . . . . . . . . . . . . 72

4.3.1. Mi az a sziget? . . . . . . . . . . . . . . . . . 72

4.3.2. Keressünk szigeteket! . . . . . . . . . . . . . . . . . 74

4.3.3. Csináljunk szigeteket! . . . . . . . . . . . . . . . . . . . 78

4.3.4. Minimális magasságú szigetek, szigetek kanonikus reprezentációja 80

4.3.5. Ismerkedés a korlátos magasságú szigetekkel . . . . . . . . . . 85

4.3.6. A sziget fogalmának kialakulását segítő Mathematica animáció . 91

4.3.7. Módszertani összefoglaló . . . . . . . . . . . . . . . . . . . . . . 92

4.4. Szigetrendszerek szerkezete . . . . . . . . . . . . . . . . . . . 93

4.4.1. Metsző szigetek . . . . . . . . . . . . . . . . . . . . . . 94

4.4.2. Maximális és minimális szigetek . . . . . . . . . . . . . . . . 96

4.4.3. Szigetek és gráfok . . . . . . . . . . . . . . . . . . . 98

4.4.4. A szigetrendszerek szerkezetének felfedezését segítő Mathematica animáció ． . . . . . . . . . . . . . . . . . . . 104

4.4.5. Módszertani összefoglaló . . . . . . . . . . . . . . . . . . . . 104

4.5. Szigetek maximális száma . . . . . . . . . . . . . . . . 105

4.5.1. Bevezetés . . . . . . . . . . . . . . . 105

4.5.2. Szigetek az $1 \times n$-es rácson . . . . . . . . . . . . 105

4.5.3. Szigetek az $2 \times n$-es rácson . . . . . . . . . . . . . . 108

4.5.4. Szigetek az $3 \times n$-es rácson . . . . . . . . . . . . . . . . 112

4.5.5. Szigetek az $m \times n$-es rácson - egy alsó becslés . . . . . . . . 113

4.5.6. Szigetek az $m \times n$-es rácson - egy felső becslés . . . . . . . . . . 114

4.5.7. Szigetek az $m \times n$-es rácson . . . . . . . . . . . . . . . . 118

4.5.8. Módszertani összefoglaló . . . . . . . . . . . . . . . . . . . . . . 119

4.6. Szigetek korlátozott magassággal . . . . . . . . . . . . . . . . . . . . 119 
4.6.1. Bevezetés . . . . . . . . . . . . . . . . . 119

4.6.2. Már ismert eredmények, $h=1,2 \ldots \ldots$. . . . . . . . 120

4.6.3. Speciális esetek, az $1 \times n$-es rács . . . . . . . . . . . 120

4.6.4. Speciális esetek, a $2 \times n$-es rács . . . . . . . . . . . . 123

4.6.5. Speciális esetek, a $3 \times n$-es rács . . . . . . . . . . . 125

4.6.6. Speciális esetek, a $4 \times 4$-es rács problémája . . . . . . . . 127

4.6.7. Módszertani összefoglaló . . . . . . . . . . . . . . . . . . . . 128

$\begin{array}{lr}\text { Összefoglalás } & 129\end{array}$

$\begin{array}{ll}\text { Summary } & 133\end{array}$

$\begin{array}{ll}\text { Köszönetnyilvánítás } & 136\end{array}$

$\begin{array}{ll}\text { Tárgymutató } & 137\end{array}$

$\begin{array}{ll}\text { Ábrák jegyzéke } & 140\end{array}$

$\begin{array}{ll}\text { Irodalomjegyzék } & 144\end{array}$ 


\title{
1. fejezet
}

\section{Bevezetés - A magyar matematikaoktatás jelenlegi helyzete}

\author{
„A legnagyobb tanári múvészet, hogy az alkotás és felismerés örömét éb- \\ ressze." (AlBerT Einstein)
}

\subsection{Komplex matematikatanítási kísérlet}

A modern magyar matematikatanítás elsô nagy korszerúsítési törekvése 1963-ban indult (részben a Szputnyik-sokk hatására). Ekkor kezdődött meg egy budapesti általános iskola (a Váci u. 43. sz. alatt) két elsố osztályában Barabás Lajosné és Tiszai Zoltánné tanítók vezetésével, Varga Tamás komplex matematikatanítási kísérlete. A nemzetközi irodalomban New Math néven ismertté vált reformtörekvések sok országban elbuktak - nem úgy Magyarországon - mert túl hirtelen, túl sokat akartak, nem illeszkedtek például a tanulók életkori sajátosságaihoz sem [107, 61]. Korábban szó sem volt gondolkodtatásról, a matematikai gondolkodás elsajátíttatásáról. A matematika nem jelentett mást, mint ismeretek rutinszerú alkalmazása, eljárások begyakoroltatása kizárólag direkt tanári irányítás alatt. Az ún. komplex matematikatanítási módszert, illetve az ezen alapuló tantervet 1978-ban kötelezốn bevezették minden elsô osztályban [131]. (Ekkoriban, 1962-ben kezdődött meg a tagozatos matematikaoktatás a Fazekas Mihály Fơvárosi Gyakorló Általános Iskola és Gimnáziumban. Az iskola hírnevét megalapozó elsô legendás osztályba járt: Lovász László, Vesztergombi Katalin, Pósa Lajos, Berkes István, Laczkovich Miklós, Major Péter és Pelikán József is, tanáruk Rábai Imre volt. Mindezekrôl részletes összefoglalás olvasható a szerzô [107] cikkében.) Ez a magyar matematikatanításban olyan gyökeres fordulatot eredményezett, mely a mai napig érezteti hatását. Ilyen fellelhetô pont például a tananyag spirális felépítése. Ehhez szükséges volt, hogy a világ nagy matematikusai felismerjék, hogy a matematika szerepe az elkövetkezendő évtizedekben meg fog nôni, s ezért annak oktatását modernizálni kell. Ebben persze komoly szerepet játszott a hidegháború. A változások alapvetôen 
két irányban indultak el. Egyrészt bekerültek az oktatásba a modern - korábban kizárólag az egyetem hatáskörébe utalt - matematika elemei (halmazok, kombinatorika, logika, valószínúségszámítás, statisztika, valamint megjelent a transzformációszemlélet a geometriában és a függvénytanban), másrészt egyre nagyobb hangsúlyt fektettek a tanulók aktív részvételére. A reformtörekvés - mint minden változás - megosztotta az embereket. Sok szülő ellenezte, nem értették ugyanis, hogy miért kell gyermeküket „egyetemi szintû” ismeretekkel terhelni. A gyerekek többsége azonban szerette a játékos matematikát. A Varga Tamás-féle új matematikatanítás lényege éppen az volt, hogy cselekedve, illetve cselekedtetve a gyerekek maguk fedezzék fel azt az ismeretet, amit át akarunk nekik adni. A matematika tanulása a tanuló aktív részvételével az egész gondolkodást formáló folyamattá lett. Az irányított felfedeztetés biztosítja a tévedés szabadságát, ugyanakkor fejleszti a kreativitást és a problémamegoldó gondolkodást.

A tanulás, mint aktív folyamat

A tanulás aktív folyamat; csak akkor lehet sikeres, ha abban a tanuló aktív cselekvéssel részt vesz.

A legfontosabb alapelv a konkrét tevékenységre épülő tapasztalatszerzés, az eszközök használata, a játékok beillesztése. A megújítási törekvés legnagyobb eredménye az volt, hogy passzív befogadóból, aktív létrehozóvá léptette elő a tanulót. Az új tanterv szerint tanulók szemlélete, felkészültsége, problémaérzékenysége lényegesen jobb lett, fogalmaik tisztábbak, használhatóbbak lettek [26].

\subsection{A magyar matematikaoktatás a nemzetközi mé- rések tükrében}

A magyar matematikaoktatástól a huszonegyedik század által megkövetlet változásokról a Szárny és Teher: A magyar oktatás helyzetének elemzése címú háttéranyagban Szalay Balázs így ír [153]: „A huszadik század matematikai és természettudományi tanterveinek tartalmát jellemzően a felsőoktatás igényei szabták meg, és elsősorban az az ismeretanyag alkotta, amely a viszonylag kisszámú matematikus, tudós és mérnök képzésének alapjául szolgált. E tekintetben különösen a matematika tananyag járt élen, kiváló felépítésének köszönhetôen egy teljesen kompakt rendszert alkotott. A modern társadalmak mindennapjaiban megnôtt a természettudományok, a matematika és a technika szerepe, így a személyes érvényesülés, a munkavállalás és a társadalmi életben való teljes értékû részvétel valamennyi felnôttôl egyre nagyobb mértékben követeli meg - és nem pusztán azoktól, akik természettudománnyal összefüggố pályán dolgoznak - a matematikai, természettudományi és technikai múveltséget." Az azonban megítélés kérdése, hogy mit is értünk matematikai múveltségen. A fogalom egyáltalán nem jóldefiniált, így a tanulási folyamat minden résztvevője (diák, tanár, szülő, társa- 
dalom, munkáltató, állam) saját aktuális igényei mentén kérhet számon ezen a néven gyakorlatilag bármit.

\section{A tudás fogalmának átértékelódése}

A több információ nem jelent több tudást. Elônyhöz az jut, aki a számára gyakorlatilag korlátlan mennyiségben rendelkezésre álló információk között kapcsolatot képes teremteni. Az érték a rendszerbe foglalt tudás [38].

Magyarország 1995 óta vesz részt az átértékelődött tudást meghatározni, illetve mérni kívánó nemzetközi összehasonlításokban.

\subsubsection{TIMSS}

Az egyik ilyet, az 1995-ben indult és négyévente lebonyolított TIMSS-vizsgálatot (Trends in International Mathematics and Science Study) oktatásszakmai célok hívták életre. A Szárny és Teher: A magyar oktatás helyzetének elemzése címú háttéranyagban Szalay Balázs így ír [153]: „A mérés voltaképpeni célja, hogy a matematika- és a természettudományoktatás fejlesztése érdekében összehasonlító adatokat szolgáltasson a résztvevố országok oktatási teljesítményének aktuális állapotáról. A trendek követése mellett keresi az adott időszakban legsikeresebbnek, leghatékonyabbnak mutatkozó oktatási gyakorlatokat. A TIMSS-vizsgálat matematikatesztje a résztvevô országok tanterveinek metszetén méri a tanulók tudását, a tesztben szereplő feladatok többsége hasonló ahhoz, amilyenekkel a magyar diákok az iskolai oktatásban találkoznak. A magyar 4. és 8. évfolyamos tanulók a TIMSS matematikavizsgálatában a résztvevô országok 500 képességpontos átlagánál jobb eredményt értek el mind a négy mérési ciklusban. A 8. évfolyam esetében az 50 résztvevô ország közül mindössze öt távol-keleti állam tanulóinak teljesítménye volt szignifikánsan jobb a magyar diákokénál."

\subsubsection{PISA}

A másik, nemzetközi összehasonlításban mérvadó mérés, a PISA-mérés (Programme for International Student Assessment - Nemzetközi Diákértékelési Program), egy gazdasági irányultságú szervezet, az OECD megrendelésére készül. Szalay Balázs összefoglalásában [153]: „Ez az elsô olyan átfogó nemzetközi felmérés, amely következetesen szakított a tanterv alapú tematikával, és elsôsorban a mindennapi életben használható tudást vizsgálja. A mérés az iskolai tanulás során elsajátított ismeretekbool és készségekbôl felépülő, az adott tudományterületen érvényes tudásra összpontosít. A matematika esetében azt méri tehát, hogy milyen mértékben képesek a tanulók a valóságos problémákat felismerni, megérteni, értelmezni és megoldani azáltal, hogy azt elôször matematikai problémákká konvertálják, majd a matematikai megoldást értelmezik a 
valós probléma tükrében." A PISA-vizsgálat tehát a matematikai eszköztudás, a matematikai alkalmazás képességének mérését túzte ki célul. A matematikai eszköztudást a kutatási terv elkészítésére felkért szakértôi csoport a következôképpen határozta meg:

A matematikai (eszköz)tudás (PISA)

Az egyénnek az a képessége, hogy képes felismerni, megérteni, milyen szerepet játszik a matematika a bennünket körülvevô világban, és ennek tükrében képes megalapozott döntéseket hozni és cselekedni, hogy jelenlegi és késôbbi élete során alkotó és felelős ember legyen [38].

Mindenképpen érdemes ezt összevetni a Pólya György által adott korábbi értelmezéssel:

\section{A matematikai tudás fogalma (Pólya György)}

Matematikát tudni annyit jelent, mint képesnek lenni matematikát múvelni. Ez jelenti a szaknyelv folyékony használatát, problémamegoldásokat, argumentumok kritikai vizsgálatát, bizonyításokat, és talán a legfontosabb matematikai aktivitást, a matematikai elvek, koncepciók észrevételét adott, konkrét szituációban [135].

Most egy új, a modern társadalom által megkívánt, gazdasági szemléletú értelmezéssel élünk. A korábbiakban ez, mint lehetséges szemléleti mód fel sem merült:

\section{A matematika tudás fogalma (Richard Skemp)}

A matematikatanítás néhány újítója igyekszik a matematikát logikai fejlôdésében bemutatni. Bár ez a megközelítés dicséretes abból a szempontból, hogy igyekszik a matematikát értelmes, nem pedig önkényes konstrukcióként megismertetni, mégis két szempontból is hibásnak mondható. Elôször is összezavarja a kérdés logikai és pszichológiai megközelítését. Egy probléma logikai megközelítésének a fô célja mindig az, hogy meggyôzze a kétkedôket. A pszichológiai megközelítés fô célja ezzel szemben az, hogy elôsegítse a megértést. Másodszor, ez a fajta megközelítés csupán a matematikai felfedezések végső eredményét szolgáltatja, és nem ismerteti meg a tanulót a matematikai felfedezés módszerével. Matematikai gondolatokat tanít, matematikai gondolkodás helyett [145].

A teszt három dimenzióban mér:

(a) matematikai tartalom;

(b) megoldási folyamat; 
(c) szituációk (személyes - saját tevékenység, társadalmi - tágabb környezet, tudományos - elméleti probléma).

A PISA-vizsgálat matematikatesztjén a magyar diákok az OECD-tagországok 500 pontos átlagánál valamivel gyengébb eredményt értek el a vizsgálat mindhárom ciklusában. A PISA-mérésben megállapított 500 pontos OECD-átlag, amelyhez viszonyítva számítják ki az összes részt vevô ország eredményét, erôsebb oktatási rendszerekben tanuló diákok átlageredményéből származtatott érték [38].

1.1. Megjegyzés. A mérést végzô kutatók arra is gondot fordítottak, hogy kikérdezzék a diákokat szociális hátterükrôl. Ide tartozik például a szülők végzettsége illetve munkája, a saját szoba, testvérek száma, a számítógép. Megállapították, hogy a magyar tanulók szociális háttere gyengébb, mint az OECD-átlag, és nagyobbak a különbségek is. Ez utóbbi arra utal, hogy a magyar oktatási rendszer képtelen segíteni diákjainak kitörni a hátrányos helyzetból. A kutatók megállapították, hogy Magyarországon valamennyi OECD-ország közül a legerôsebb a családi szociális-kulturális háttér és az iskolai teljesítmény kapcsolata. Ha ez a kapcsolat erős, az azt jelenti, hogy a hátrányos helyzetú tanuló nem tud a képességeinek megfelelôen teljesíteni.

\subsubsection{A TIMSS és PISA mérések eredményeinek összehason- lítása}

A PISA-vizsgálatban a világ fejlett országainak többsége részt vett. A TIMSS-mérésból hiányzott Finnország, Svájc, Liechtenstein, Belgium, Észtország, Izland, Írország, Franciaország, Lengyelország, Luxemburg, Spanyolország, Horvátország, Portugália, Görögország. Ugyanakkor a TIMSS-mérés számos fejlődő ázsiai, közelkeleti és afrikai országra is kiterjedt [153]. A következô ábra a [153] tanulmányból származik.

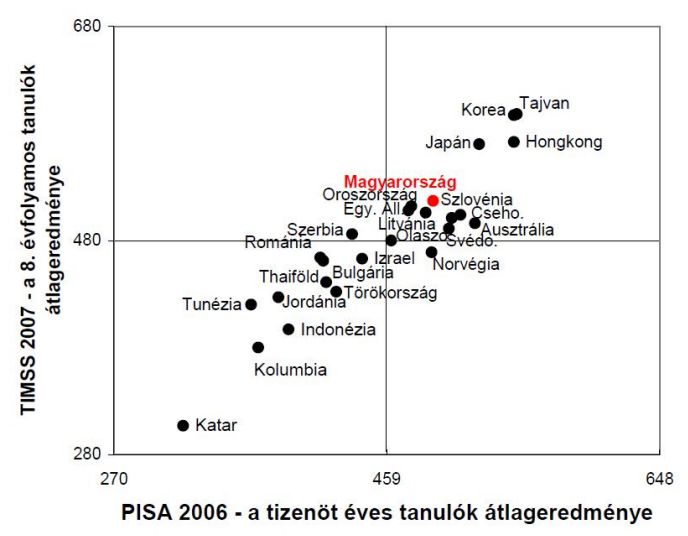

1.1. ábra. A PISA 2006 és a TIMSS 2007 eredményeinek összehasonlítása matematikából 
A tudás mérésének viszontagságai

A diákoktól semmi esetre sem szabad elvárni, hogy olyan problémákat oldjanak meg, amelyekre nem készítettük fel ôket, melyekkel nem találkoztak korábban a tanulmányaik során.

A PISA tesztek tulajdonképpen ilyenek voltak, hiszen:

(a) A feladatok sem tartalmukban, sem megfogalmazásukban nem illeszkedtek a magyar matematikatanítási kultúrába, hagyományokba. (Ellentétben a finn oktatáskultúrával mely hagyományosan gyakorlati jellegú és az élethez közeli, sok tanterven kívüli foglalkozással.)

(b) A számonkérés módja teszt jellegú volt, amely szintén idegen a magyar hagyományoktól. S mivel a teszt jellegú számonkérés nem jelenik meg a kimeneti mérésekben (nyolcadik oszályos felvételi, érettségi), ezért nem is készítjük fel a diákjainkat ilyen típusú feladatok megoldására. Itthon marginálisan, kizárólag versenyek (Zrínyi Ilona Matematikaverseny, Gordiusz Matematika Tesztverseny, Hajnal Imre Matematika Tesztverseny, Nemzetközi Kenguru Matematikaverseny (Franciaországból adaptálva), Bolyai János Matematikai Csapatverseny (részben), néhány internetes tesztverseny (pl. Mozaik Tanulmányi Verseny)) formájában jelenik meg, viszont Finnországban szokásos formája a számonkérésnek.

(c) A vizsgált populáció (15 évesek) választása a finn rendszernek kedvez, hiszen ott ez az életkor iskolai fokozatot zár, míg nálunk nem.

(d) A feladatsornak nem volt sem egyéni, sem közösségi tétje.

(e) A feladatsor hosszú volt, bonyolult, fejlett szövegértési készséget igényelt, melynek a magyar diákok szintén híján vannak. (A finn diákok szövegértése kiemelkedő.)

(f) A feladatok komplexek voltak, gyakorlati ismeretek összekapcsolását igényelték [82].

\subsection{A kompetencia fogalma és szerepe az oktatásban}

A XXI. században az ismeretelsajátítás szükségességét bizonyos kompetenciák megszerzésének fontossága váltotta fel. A nyolcvanas évek végén és a kilencvenes évek elején erre a változásra paradigmaváltással adott választ a mérési-értékelési szakma: a korábbi tantervi alapú, tartalmi elemekre összpontosító mérések mellett megjelentek a kompetencia alapú mérések is.

\subsubsection{A kompetencia fogalma}

Jelenleg az oktatásfejlesztés egyik legdinamikusabban fejlődő kutatási területe a kompetenciák vizsgálata. A kompetencia fogalma nem egységes, mást és mást jelent az 
élet különböző területein, de a fogalom oktatás területén betöltött jelentése is jelenleg még inkább csak kialakulóban van.

Az alábbiakban csak néhány megközelítést említünk.

\section{A kompetencia fogalma (Coolahan ${ }^{1}$ )}

A kompetenciát úgy kell tekinteni, mint olyan általános képességet, amely a tudáson, a tapasztalaton, az értékeken és a diszpozíciókon alapszik, és amelyet egy adott személy tanulás során fejleszt ki magában [161].

\section{A kompetencia fogalma (Nagy József)}

A kompetencia a személyiség alkomponensrendszere, mely további komponensekre bontható, úgy mint: képességek, egyszerú és komplex készségek, öröklött és tanult rutinok és ismeretek [122].

\section{A kompetencia fogalma (Halász Gábor)}

A kompetencia az a képességünk és hajlandóságunk, hogy a bennünk lévô tudást (ismereteket, készségeket és attitúdbeli jellemzóket) sikeres problémamegoldó cselekvéssé alakítsuk [66].

\section{A kompetencia fogalma (Felnôttképzési Törvény)}

A képzésben részt vett személy ismereteinek, készségeinek, képességeinek, magatartási, viselkedési jegyeinek összessége, amely által a személy képes lesz egy meghatározott feladat eredményes teljesítésére [48].

Az oktatás számára legfontosabbak az ún. kulcskompetenciák. Ez a kompetenciák azon szúkebb köre, amellyel minden embernek rendelkeznie kell. (Ezek azok a kompetenciák ugyanis, amelyek alapul szolgálnak pl. a funkcionális kompetenciák kialakulásához.) Az EU meghatározása e tárgykörben jelenleg a következô:

\section{A kulcskompetencia fogalma (EU)}

A kulcskompetenciák az ismeretek, készségek és attitűdök átvihető, többfunkciós készletét képviselik, melyre minden egyénnek szüksége van az önmegvalósításhoz és fejlődéshez, beilleszkedéshez és munkavállaláshoz. Ezeket a kötelezô iskolai oktatás vagy képzés befejezéséig ki kell fejleszteni, és az egész életen át tartó tanulás részeként a további tanulás alapjául kell szolgálniuk [45].

\footnotetext{
${ }^{1}$ John Coolahan, ír pedagógus, az Európai Tanács szakértóje
} 
Magyarországon a NAT [121] 2007-es módosításába került be a nyolc kompetenciát:

(1) anyanyelvi kommunikáció;

(2) idegen nyelvi kommunikáció;

(3) matematikai kompetencia,

(4) természettudományi és technológiai kompetencia;

(5) digitális kompetencia;

(6) a tanulás tanulása;

(7) személyközi (szociális) és állampolgári kompetencia;

(8) vállalkozói kompetencia;

(9) kulturális kompetencia.

tartalmazó keretrendszer.

Magyarországon a kompetencia alapú oktatás elterjesztésére irányuló projektek 2004 és 2007 között elsősorban a HEFOP (Humánerőforrás-fejlesztési Operatív Program), 2007-tôl pedig a TÁMOP 3.1.4 (Társadalmi Megújulás Operatív Program) keretein belül indultak el. A továbbiakban a matematikai kompetencia fogalmával foglalkozunk.

\subsubsection{A matematikai kompetencia}

A matematikai kompetenciákat először Mogens Niss dán kutató foglalta össze [119]:

(1) matematikai gondolkodás és következtetés;

(2) matematikai argumentáció;

(3) matematikai kommunikáció;

(4) modellezés;

(5) problémafelvetés és -megoldás;

(6) reprezentáció, ábrázolás;

(7) szimbolikus, formális, nyelvi, technikai múveletek alkalmazása;

(8) eszközhasználat.

A kompetenciákat az alábbi osztályokba sorolhatjuk:

(a) reproduktív osztály;

(b) integratív osztály;

(c) kreatív osztály.

Tartalmi szempontból a következô bázispontok köré építkezhetünk:

(i) tér és alakzat;

(ii) változások és relációk;

(iii) mennyiségek;

(iv) bizonytalanság.

Ezeket a késôbbiekben különbözô kutatások a saját vizsgálati modelljükben részben módosítottan kezelték [4]. 


\subsubsection{Az Országos kompetenciamérés}

Az Országos kompetenciamérés 2001-ben indult. A vizsgálat az iskolarendszer 4. évfolyamán tanuló diákok körében az alapkészségek, 6., 8. és 10. évfolyamon pedig a matematikai eszköztudás és a szövegértési képesség felmérésére terjed ki. Az ország összes iskolájának minden telephelyén minden 4., 6., 8. és 10. évfolyamos tanuló azonos idôpontban és azonos feltételek mellett írja meg a tesztet. A tesztek eredményeinek elemzésébốl megállapítható, hogy 6 . és 10. évfolyamos diákok matematika eredménye gyakorlatilag nem változott, míg a 8. évfolyamos diákoké csökkent 2003 és 2007 között [153].

A mérések fogadtatása nem volt egyöntetúen pozitív. A szakma a feladatsorokat hosszúnak, a feladatokat a magyar matematikaoktatási kultúrától és szokásoktól idegennek tartotta. Ezen utóbbi oknál fogva viszont nem is várható el, hogy a tanulók itt nyújtott teljesítményét kiértékelve alkossunk értékítéletet. Pedig sajnos ez történik. Az iskolákat ezen mérés eredményei alapján ítélik meg, s az ítélkezés olykor erôs hangvételú. Éppen ezért a fenntartó, s rajta keresztül az iskola vezetôsége igyekszik minél jobb eredmény elérésére ösztökélni diákjait, de elsôsorban tanárait. Így nem egyszer, nem egy iskolában adták utasításba a tanároknak, hogy a teszt megírása előtt készítsék fel erre diákjaikat. Ezen igényt kielégítendô, erre a célra feladatgyújtemények is jelentek, jelennek meg szép számban [10, 41, 100, 101, 127, 128, 149, 150]. Mindez ellentétes a kompetenciamérés elveivel, hiszen ezek szerint erre a mérésre nem lehet előre készülni! Másrészt teljesen megbontja a tananyag elôzetes, logikus felépítését, az érettségire való folyamatos, hosszú távú felkészülést, hiszen a mérésben található feladatok semmilyen formában nem egyeztethetốk össze a majdani kimeneti mérés feladataival. Külsố nyomásra a tanárok nem csak, hogy a tesztre kénytelenek elôre felkészíteni, hanem a teszt megíratása során(!) is sok esetben segíteniük kell tanítványaikat. Ez viszont jelentôs mértékben torzítja a mérés eredményét, irrelevánssá téve azt. Ráadásul a kompetenciamérésekre való pánikszerú felkészítés után minden visszatér a rendes kerékvágásba; a mérések tehát nem érik el egyik legfontosabb céljukat, a szemléletváltást. Nem is lenne szerencsés ha elérnék, egészen addig, amíg az nem jelenik meg a kimeneti mérésekben (8. osztályos felvételi, érettségi). Az idegenkedés másik oka a mérés megíratásának módja. A mérés egy teljes napra megakasztja az iskola életét. A lebonyolítás operatív része az iskola feladata. A megírás során a teszteket félig-meddig titkosítják. A megírt feladatlapokat elszállítják az iskolából, a tanárok nem értesülhetnek az egyes diákok teljesítményéről. Csupán egy, az egész iskolára levetített összesített eredményt kapnak, amely nem segít az esetleges hiányok, illetve ezek okainak, forrásának feltárásában, pedig ez lehetne az ilyen egységes mérések egyetlen közvetlen haszna. 


\subsection{Kiutak keresése: modellezés és valóságközeli ma- tematika}

\subsubsection{Matematikai modellezés}

A matematikai modellezés a XX. században alakult ki, elsősorban a kognitív pszichológia fejlődésének hatására. A modern matematikadidaktika sem kezeli már a matematikát a valóságtól teljesen elszakítva, hanem vallja, hogy a kapcsolatok kétoldalú bemutatásával együtt, elválaszthatatlan egységként érdemes őket kezelni [52]. Azóta a témában számos konferenciát tartottak, (az elsốt 1985-ben az ICTMA (International Conference of Teaching Mathematics Applications) szervezésében) illetve az EU a németországi University of Education koordinálásával számos ország részvételével (Franciaország, Németország, Magyarország, Ciprus, Spanyolország, Egyesült Királyság) LEMA (Learning and Education through Modelling and Applications) néven külön projektet is indított a témában, melybe 2006 szeptemberétól Magyarország is bekapcsolódott [91]. A projekt célja egy olyan tanítási segédanyag kidolgozása, melynek segítségével az Unió bármely országában az oktatás bármely szintjén megkönnyíti a matematikai modellezés oktatásba való integrálását.

Maga a modell, illetve a modellezés fogalma is jelentôs változásokon ment keresztül, jelenleg Blum értelmezése a legelterjedtebb.

A matematikai modellezés fogalma (Blum)

A matematikában általánossá vált a modellezés megnevezés alkalmazása arra a teljes folyamatra, amely magában foglalja a strukturálás, matematizálás, matematikai kidolgozás, és interpretálás/validálás (esetleges többszöri végrehajtását) a végső, elfogadható eredmény érdekében [15].

A modellezési ciklus jól használható modellje a PISA 2003 tanulmányban jelent meg [158].

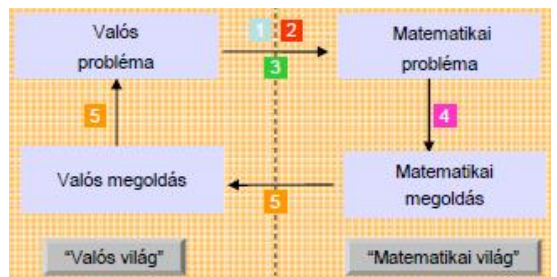

1.2. ábra. A modellezési ciklus (PISA 2003)

(1) Induljunk ki egy valós környezetben lévô problémából.

(2) Rendezzük el ezt a matematikai fogalmak szerint, valamint ismerjük fel az ide vonatkozó matematikai eljárásokat. 
(3) Fokozatosan vagdossuk le a valóság elemeit olyan folyamatok segítségével - mint például feltételezés, általánosítás és formalizálás - melyek előtérbe helyezik a szituáció matematikai vonásait és a valós problémát olyan matematikai problémává alakítják, amely hitelesen reprezentálja a szituációt.

(4) A matematikai probléma megoldása.

(5) Értelmezzük a megoldást a valós szituációra vonatkoztatva.

A fenti modell Blum munkássága nyomán egy fontos elemmel fejlődött; a szituáció megértése, a szituációból készített modell, külön lépésként jelenik meg. A továbbiakban a modellezés folyamatában csak a szituációs modell vesz részt, vagyis az a „valóság”, ahogyan a tényleges szituációt megértettük, értelmeztük [15]. Az alábbi ábra a [16] tanulmánykötetból származik.

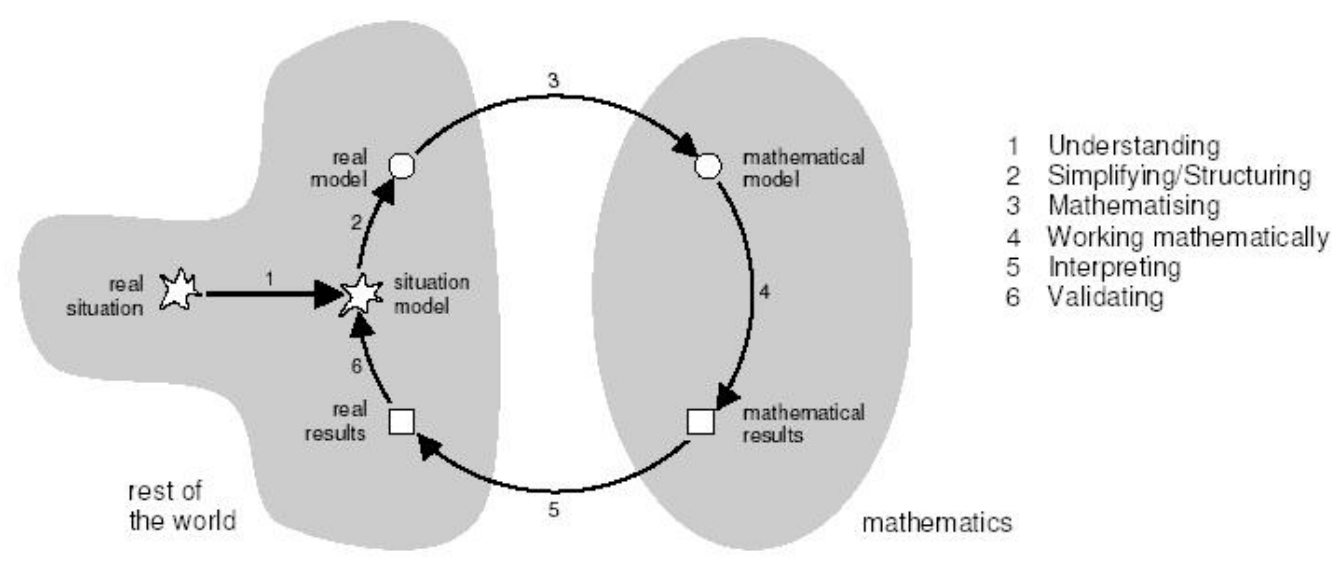

1.3. ábra. A Blum-modell

1.2. Megjegyzés. Ahogy látható, egyik modellból sincs „kilépés”. Ennek oka, hogy a hangsúly magán a folyamaton, és nem annak eredményén van.

Modellek használhatók egyrészt szituációk leírására, pl. alganövekedés, szerencsejátékok. Ezeket leíró modelleknek nevezik. Másrészt modellek készíthetôk bizonyos szándékok adott körülmények közötti megvalósítására, pl. választási eljárások, értékelési eljárások készítéséhez. Ez utóbbiak a normatív modellek.

A modellezési feladat megoldása során a hangsúly azon a folyamaton, eljáráso(ko)n van, amelyet a tanulónak kell megtalálnia és végrehajtania ahhoz, hogy egy matematikán kívüli probléma és valamely matematikai tartalom között megfelelő kapcsolatot teremtsen. Ilyen jellegú „fordítási eljárás” a matematikán belül is létezik, például amikor geometriai probléma kerül formalizálásra. Ebben az esetben matematikán belüli modellezésrôl beszélünk [4].

Ezeket a feladatokat a diákok rendszerint csapatmunkában kell, hogy megoldják (már csak a szerteágazó részfeladatok miatt is), mely teljesen idegen a magyar oktatási 
hagyományoktól. Erre még a tanárok sincsenek felkészülve, híján vannak pl. a fejlesztő kérdéseknek, melyekkel folyamatosan irányítaniuk kellene a csoportmunkát, illetve a diákok sem tudják, hogyan is értékeljék egymás által a csoportok munkáját. Arról nem is beszélve, hogy a modellezési feladatok matematikán kívüli ismereteket is igényelnek, melyek általában egyáltalán nem triviálisak, és amelyeknek sokszor még a legfelkészültebb tanárok sincsenek birtokában [159]. Ugyanakkor a módszer kétségkívül igazán alkalmas a tanulók komplex problémamegoldásának fejlesztésére.

\subsubsection{Valóságközeli vagy realisztikus matematika}

A XX. század végére a matematikai nevelés leglényegesebbnek tekinthetô kérdéseihez az előző évtizedek realisztikus matematikaoktatási irányzata visz közel. Elindítójának Hans Freudenthal ${ }^{2}$ tekinthetô. Munkásságát a nevét viselő matematikadidaktikai kutatásokkal fogalakozó intézet (Feudenthal Institute for Science and Mathematics Education $^{3}$ ) folytatja. (Az intézet által folytatott kutatások, illetve az általa képviselt szemlélet nagy mértékben összecseng Varga Tamás elképzeléseivel.) Az irányzat alapvető gondolata, hogy a tanulók nem készen kapott ismeretek befogadói a matematikatanítás során, hanem lehetôségük van nagyszámú, változatos környezetbôl vett probléma, különbözố szituációk vizsgálata alapján a matematikai fogalmak, koncepciók, tételek felfedezésére. A „realisztikus” jelzô azt fejezi ki, hogy a tanulók tapasztalatszerzését úgy kell megszervezni, hogy az általuk vizsgált problémák reálisak, elképzelhetőek, jelentéssel bírók legyenek a számukra. Ez jelentheti a valóságból vett jelenségeket, objektumokat éppúgy, mint a korábbi tapasztalatokból ismert matematikai kontextusokat. Tanulmányában Somfai Zsuzsa erről így ír [148]: „A problémából indított tapasztalatszerző folyamatban a tanulók szembesülhetnek különbözô megoldási módokkal. Így közben megtanulják, hogyan lehet saját álláspontjukat megvédeni, mások munkáját kritikusan meghallgatni, mérlegelni, a másik munkáját értékelni. Egy adott pillanatban bekövetkezik az absztrakció, az általánosítás, a formalizálás indokolttá válása, de nem minden tanulónál egyszerre. Ennek a matematikatanítási irányzatnak az érvényesülése megváltoztatja a tanár és a tanulók tradicionális szerepét a tanulási folyamatban. A tanár az abszolút tekintélyből a folyamatot irányító, segítô személyiséggé válik. A megfellebbezhetetlen közlések helyett a segítés, kérdezés, a tanulók gondolkodásának árnyalt követése lesznek a fô tanári tevékenységek. A tanulók passzív befogadó helyett aktív szereplőkké válnak."

Az MUED német matematikatanár-szervezet elôzetes munkájának köszönhetôen 2004-ben elindult DQME (Developing Quality in Mathematics Education) néven egy 3 éves uniós projekt, melynek célja, hogy a matematikát az akadémikus stílus helyett, egy valóságközeli, praktikus eszközként segítse kezelni [39]. Ezen projekt egyik fô célja az újságcikkeken, médiából vett szituációkon keresztül a diákok kritikai gondolkodásának fejlesztése, melyet az öntudatos EU polgár egyik legfontosabb erényének tartanak.

\footnotetext{
${ }^{2}$ Hans Freudenthal (1905-1990) német matematikus

${ }^{3}$ http: //www.fi.uu.nl/
} 
Emellett fontos a világ problémáinak megértése és megismerése. Továbbá nemzetközi felmérések azt bizonyítják, hogy azok a diákok válnak a matematika tudatos felhasználóivá, akik az iskolában is tanultak az alkalmazásokról [102].

\subsection{A jelen helyzet és a jövő társadalmának elvárásai}

A nevelési-oktatási rendszer újjáépítéséhez szükséges pedagógiai megújulás idevágó lényeges elemei a Szárny és Teher Konferencia alapján a következókben foglalhatók össze [38]:

(1) az erkölcsi és esztétikai, az olvasási-szövegértési készségek, a beszédkészség, az írás és az infokommunikációs készségek fejlesztése - össztantárgyi feladat;

(2) a kísérletezés - kulcspont a természettudományos oktatás megújulásában;

(3) az infokommunikációs módszertár - a pedagógia új eszköze.

A matematika kapcsán a legfontosabb elvárásokat a Kerettanterv [85] így fogalmazza meg:

(1) a modellalkotás, matematizálás jelentőségének növekedése;

(2) a matematika alkalmazási terének növekedése;

(3) egyensúly a matematika belsô struktúrájának kiépítése és a tanultaknak a mindennapi életben, más tárgyakban való felhasználása, eszközként való alkalmazása között;

(4) a modern oktatási, tanulási technológiák beépítése a mindennapi iskolai oktatási, nevelési tevékenységbe.

Ezzel szemben egy 2003-as felmérés szerint a tanárok óráikon szinte egyáltalán nem használnak informatikai eszközöket. Az alábbi táblázat 169 válaszolóra vonatkozó adatokat tartalmaz [147]. (A gyakoriságra vonatkozó adatok százalékban értendók.)

\begin{tabular}{|l||l|l|l|l|l|l|c|}
\hline Eszközök & $\begin{array}{l}\text { soha } \\
(1)\end{array}$ & $\begin{array}{l}\text { ritkán } \\
(2)\end{array}$ & $\begin{array}{l}\text { néha } \\
(3)\end{array}$ & $\begin{array}{l}\text { elég gyakran } \\
(4)\end{array}$ & gyakran (5) & átlag & szórás \\
\hline $\begin{array}{l}\text { kereskedelmi } \\
\text { forgalomban } \\
\text { vásárolt digitális } \\
\text { eszközök }\end{array}$ & 38,9 & 37,7 & 18,6 & 4,8 & 0 & 1,89 & 0,87 \\
\hline $\begin{array}{l}\text { házilag ké- } \\
\text { szült digitális } \\
\text { eszközzök }\end{array}$ & 59,6 & 27,0 & 8,6 & 4,3 & 0,6 & 1,60 & 0,87 \\
\hline $\begin{array}{l}\text { ingyenes multi- } \\
\text { média tananyag }\end{array}$ & 50,4 & 31,5 & 28,6 & 9,6 & 1,8 & 2,19 & 1,01 \\
\hline internet & 23,4 & 34,1 & 28,1 & 9,6 & 4,8 & 2,38 & 1,08 \\
\hline prezentációkészítố & 65,2 & 22,6 & 7,9 & 2,4 & 1,8 & 1,53 & 0,88 \\
\hline $\begin{array}{l}\text { szz̈vegszerkesztó, } \\
\text { táblázatkezelő }\end{array}$ & 23,1 & 22,5 & 23,1 & 16,0 & 15,4 & 2,78 & 1,37 \\
\hline
\end{tabular}

1.4. ábra. Informatikai eszközök használati gyakorisága a matematikaórákon 
Az objektív okok között feltétlenül szerepelnek a technikai problémák. Az iskolák többségében nem megoldott, hogy a tanár bármelyik órán külön szervezés nélkül számítógépet használjon. Ennek a körülménynek a hiányában esetleges és nagyon fáradságos, időigényes az olyan óra előkészítése, ahol elektronikus eszközt használhat a tanár. Kevesen vállalkoznak ilyen természetú, önállóan fejlesztett anyag készítésére [147]. A taneszközválaszték az elektronikus eszközök területén az elmúlt években robbanásszerú fejlődésnek indult. A ma tankönyvei DVD kiegészítésekkel jelennek meg, ismét készülnek tanári segédkönyvek, melyek szinte kizárólag ebben a formátumban férhetôk hozzá (nem egy esetben a feladatgyújtemények megoldásköteteivel egyetemben).

A fenti felmérés eredményei szerint a módszerek tekintetében sem jobb a helyzet [147]:

\begin{tabular}{|l||l|l|l|l|l|l|l|}
\hline Módszerek & $\begin{array}{l}\text { soha } \\
(1)\end{array}$ & $\begin{array}{l}\text { ritkán } \\
(2)\end{array}$ & $\begin{array}{l}\text { néha } \\
(3)\end{array}$ & $\begin{array}{l}\text { elég gyakran } \\
(4)\end{array}$ & gyakran (5) & átlag & szórás \\
\hline $\begin{array}{l}\text { tanári magya- } \\
\text { rázat }\end{array}$ & 0 & 0 & 3,6 & 32 & 64 & 4,61 & 0,56 \\
\hline $\begin{array}{l}\text { frontális } \\
\text { osztálymunka }\end{array}$ & 0 & 1,7 & 8,1 & 45,3 & 44,8 & 4,33 & 0,70 \\
\hline $\begin{array}{l}\text { önálló tanulói } \\
\text { munka }\end{array}$ & 0 & 5,2 & 15,1 & 56,4 & 23,3 & 3,98 & 0,77 \\
\hline differenciálás & 1,2 & 11,6 & 37,2 & 41,9 & 8,1 & 3,44 & 0,85 \\
\hline csoportmunka & 5,2 & 31,4 & 35,5 & 20,3 & 7,6 & 2,94 & 1,02 \\
\hline pármunka & 23,4 & 42,7 & 22,8 & 10,5 & 0,6 & 2,22 & 0,94 \\
\hline projektmódszer & 41,1 & 36,1 & 19,0 & 3,8 & 0 & 1,85 & 0,86 \\
\hline terepmunka & 77,8 & 18,0 & 3,6 & 0,6 & 0 & 1,28 & 0,59 \\
\hline
\end{tabular}

1.5. ábra. Tanulásszervezési formák gyakorisága a matematikaórákon

A tanári magyarázat, a frontális osztálymunka, az önálló tanulói munka, illeszkedik a magyar matematikaoktatás hagyományos módszerei közé, illetve ki is meríti azt. A differenciálás megléte, vagy hiánya nem a tanáron múlik. Az anyagi, illetve szervezési lehetőségek korlátai szabják meg azt, hogy van-e rá lehetôség. Az idézett tanulmány ([147]) szerint az osztályok kevesebb, mint 30 \%-ában van szintek szerinti csoportbontás, az is fóleg csak a felsô két évfolyamon jellemző, ahol ezt már az érettségire való felkészítés megkívánja. A differenciálás ezen esetben sem a tanulók valódi, hanem a választott (elérni kívánt) tudásszintjéhez igazodik. A csoportmunka idegen a magyar oktatási hagyományoktól; nem is múködtethetô 35-38 fős osztályokban. A terepmunka idegenül hathat a matematikaóra kapcsán, viszont Angliában, illetve az USA-ban ennek komoly hagyományai vannak. Célja a közvetlen tapasztalatszerzés (mérés, megfigyelés, adatgyưjités, kísérletezés). A projektmódszer múködtetéséhez sem hagyományaink sem segédeszközeink nem nyújtanak segítséget, ezen felül nagymértékú kreativitást, idôráfordítást igényel.

A PISA, illetve a kompetenciamérések fogadtatása meglehetôsen vegyes volt. A mérések tartalma szakmai vita tárgyát képezte és képezi jelenleg is. Vitatói elsôsor- 
ban azt nehezményezik, hogy a mérések feladatai szellemükben és tartalmukban nem igazodnak a tantervekhez és az iskolai matematikaórák gyakorlatához. Néhányan bírálták a mérések feladatainak szakmai hitelességét is. A mérések tartalmával szimpatizáló szakemberek általában úgy vélik, szükség van az alkalmazásképes tudás mérésére, mert ez az oktatási rendszer hatékonyságának egyik fontos mutatója. A tanárokat nem kiképezték, hanem kényszerítették az új szemléletú oktatásra, az iskolákat is részben a kompetenciamérések eredményei alapján ítélik meg. A méréseknek a tanárok kizárólag elszenvedôi, nem aktív részesei. Ugyanakkor elvárás a tanárral szemben a diákok kompetenciáinak fejlesztése, az új számonkérési módszerekre való felkészítés.

A középiskolai (matematika)oktatás présben helyezkedik el. Alulról az általános iskolai óraszámcsökkentés hatására van nyomás alatt. Az elmúlt években az általános iskola felsố tagozatán a matematika óraszáma heti négyrôl háromra csökkent. Ez a 25\%-os csökkentés olyan, mintha a négy év tankönyvei közül egyet kiválasztva azt egyszerúen kidobtuk volna. A hasonlat egyáltalán nem túlzó, viszont több szempontból is fals, legfóképpen azért, mert az óraszámcsökkentés egyáltalán nem állt arányban a tananyagcsökkentéssel. Így a középiskolába többségében bizonytalan, formális ismeretekkel rendelkezô diákok kerülnek, akik nincsenek a szükséges készségek, képességek birtokában. Ezek kialakítására a középiskolának nincs lehetôsége. Ezek egyrészt az általános iskolai életkorhoz kötöttek, másrészt rendkívül időigényesek. A prés felsô lapját a tankötelezettség megemelése, valamint a tömegek felsőoktatásba irányítása jelenti. A tankötelezettség 18 évre emelésével rengeteg motiválatlan, a korábbinál jóval kevésbé felkészült gyerek ül a középiskolában. Óket nem csak, hogy az érettségiig, de a sikeres felsőoktatási felvételihez is el kell juttatnia a középiskolának, ami szinte lehetetlen vállalkozás.

A tanárral szembeni közvetlen szülői, illetve társadalmi elvárás is kettős és ellentmondásos. A matematikai ismeretek alkalmazását, alkalmazható tudást várna el egyre inkább a társadalom, a nemzetközi mérések is ezt mérik, s nem a tantervi tudást. Ugyanakkor a tanárral szemben a társadalom elvárása a kimeneti mérésnek való megfeleltetés, az érettségire való felkészítés is. A legfontosabb még mindig az érettségihez szükséges tárgyi ismeretek átadása, mely nem hogy a fentiekkel, de sokszor még a felsôoktatás elvárásaival sincs szinkronban. Számos hazai felmérés bizonyítja ugyanis, hogy a múszaki, matematikai, informatikai szakterületen egyetemre, főiskolára járó diákok elsô évben, elsôsorban a bevezetô jellegú matematikai kurzusokon mutatott teljesítménye nem korrelál sem a középiskolai, sem az érettségi eredményekkel (az érettségi választott szintjétól függetlenül). Kimutatható kapcsolat mindössze a versenyeredményekkel van [117].

A probléma mindezektôl függetlenül valahol nagyon mélyen gyökeredzik. Megdöbbentő adat, de a középiskolát végzettek $90 \%$-a az érettségi utáni 3 éven belül elveszíti a megszerzett matematikai ismeretei 90\%-át. E vizsgálat szerint az Amerikában és Magyarországon érettségizô diákok tudása között a különbség három és félszeres a magyar diák javára. Tíz év múlva viszont az amerikai több mint kétszer annyit tud. Az amerikai még mindig tudja a hetvenöt százalékát annak, amit megtanult; a magyar 
mindössze tíz százalékra emlékszik [50].

Jelen pillanatban is zajlik a közoktatási és a felsôoktatási törvény vitája. A törvények nyithatnak új utakat, teret engedhetnek új elképzeléseknek, s ezzel egyszerre természetesen új kihívások elé állíthatják a tanárokat. A fố kérdés persze az, hogy a folytonos reformok által felörölt, a társadalmi megbecsülés alacsony szintjén álló tanártársadalom képes lesz-e megfelelni az állandóan változó, különbözô fórumok által különbözôképpen interpretált elvárásoknak. „A versenyre és a szolidaritásra kell felkészíteni a diákokat, s ennek az új közoktatási törvényben is meg kell jelennie [116]." (PÁlinkás JózSEF, a Magyar Tudományos Akadémia elnöke)

\section{6. Összefoglalás}

A múszaki-tudományos változásoknak, ezen belül is elsôsorban az informatika és kommunikáció fejlődésének, a huszadik század történelmét alapvetően meghatározó információrobbanásnak igen jelentôs hatása volt az oktatásra is. Ez határozta meg az oktatási-nevelési célok változását, az oktatás tartalmának jelentős módosulását, eszközállományának teljes modernizálódását, a tanításban alkalmazott módszerek megváltoztatására való törekvéseket, a mérések tartalmát és módszereit [80]. A globalizáció által motivált legfóbb elvárás az oktatás felé az volt, hogy gyorsan mobilizálható ismeretet nyújtson alacsony ráfordítással.

Az információrobbanás hatására tehát a tudás, s azon belül a matematikai tudás (múveltség) fogalma átértékelődött. A releváns mérések a tanulói teljesítményt integrált módon kísérlik meg felmérni, ahelyett, hogy a tárgyi tudás különálló elmeire fókuszálnának. Elvész a lexikális tudás nimbusza. (Furcsa paradoxon, hogy becslések szerint a NAT bevezetése óta, annak deklarált célja ellenére, megduplázódott a 6-10 évesek számára készült tankönyvekben, munkafüzetekben stb. az ismeretanyag mennyisége. Ez feszítettebb tempót diktál, s kevesebb idő jut az ismeretek kulcsfontosságú tapasztalati előkészítésére, az alapkészségek rutinjainak kidolgozására, a tanultak gyakorlati felhasználására. Nem kedvez ez a felfedezés örömének, a tévedések felismerhetôségének, kijavításának [155].)

Az újraértelmezett matematikatudásban fontos szerepet játszik az, hogy a matematikát különbözô helyzetekben alkalmazzuk. Szemponttá lépett elô, hogy olyan problémákat, feladatokat és végsố soron olyan tankönyveket adjunk a gyerekeknek, amelyekból megértik, hogy a mai világ nem létezik matematika nélkül. Gyakorlatiasabb matematikára van hát napjainkban szükség. Ez a tanulók többségét érdekli, s így komoly motivációs tényezô [50].

A változás - különösen a magyar matematikaoktatás tekintetében - nagyobb mértékú és mélyebb, mint azt elôzetesen gondolnánk. A magyar matematikaoktatás ugyanis inkább elméleti és problémamegoldó, és nem gyakorlati problémák formális megoldását célozta. A tananyag felépítése a másutt szokásosnál jobban építi a tudomány belsô logikájára, és kevésbé a gyors alkalmazhatóságra. A matematika érettségi 
nálunk mindig is megkövetelte az elmélet megfogalmazását, tételek bizonyítását. A nemzetközi kritika szerint túlzottan akadémikus tudást adnak a magyar iskolák. A diákok öt százalékának, akikból értelmiségi lesz, ez kétségtelenül hatalmas elônyt jelent. De csak nekik. Azaz olyan oktatási rendszerünk van, amely a tehetséges tanulóknak kedvez. Magyarországon abszolút elit oktatás alakult ki és nem olyan, amely a tömegekre is kiterjedt volna, a gyengéket is igyekezett volna felemelni és nivellálni [50].

Sajnos jellemző, hogy még nem tudunk elszakadni a porosz típusú pedagógusi attitûdtốl. Pedig az oktatással szemben támasztott elvárásokat többé nem a felsôoktatás, hanem a társadalom folyamatosan változó igényei szabják meg, s ez meg kell, hogy mutatkozzon a módszerekben is. Többé már nem a tanár a tanuló elsôdleges információforrása. (Bár talán a matematika az egyik olyan terület, ahol ez még vitatható.) A tanárnak nem az információ átadása, hanem az információtengerben való eligazodás segítése, a megszerzett tudás alkalmazásának bemutatása a fô feladata. Éppen ezért (uniós) elvárás az infokommunikációs technológiák (IKT) használata, a projektmódszer, illetve a kutatásközpontú oktatási módszerek (IBL/T - Inquiry-based learning/teaching, kutatásalapú tanulás/tanítás) alkalmazása - biztató hazai példa az Út a tudományhoz és a KUTDIÁK program - az oktatásban a számítógépek alkotó jellegú felhasználása mellett. 


\section{2. fejezet}

\section{Felfedezések a matematikában}

„A számitógép már érezteti hatását a matematikában éppúgy, mint annak idején a távcsố és a mikroszkóp a csillagászatban és a biológiában." (DORON ZEILBERGER)

\subsection{Bevezetés}

Ebben a fejezetben röviden bemutatjuk a matematika egy új szemléleti lehetôségét, a kísérleti matematikát (experimental mathematics), illetve ennek az oktatásban való, a dolgozaton végigvonuló alkalmazását készítjük elô, didaktizáljuk. Összekapcsoljuk kísérleti matematikánkat a heurisztikával, a problémamegoldó gondolkodással, illetve megvizsgáljuk a módszer lehetséges hatásait. Röviden kitérünk a bizonyítások tanításának jelenlegi problémáira, valamint lehetôséget mutatunk arra, hogyan lehet ezen problémákat módszerünk segítségével orvosolni.

\subsection{Experimental Mathematics}

\subsubsection{Kísérleti matematika}

A matematikát a formális természete és a deduktív érvelési rendszere választja el a természettudományoktól. Bár a matematika története a felfedezések története, mégis a diákok szemszögéból nézve a kísérletek eddig látszólag nem játszottak jelentôs szerepet a matematikában. A kísérletezés, a felfedeztetés legfóképp az idóhiány miatt az elmúlt években jelentôsen háttérbeszorult. Pedig a formalizmus csak a rendszerezésben, a bizonyosság növelésében, a tudás megszilárdításában segít; az új tudás mindig megfigyelés és kísérletezés útján keletkezik, a matematikában is. A kísérletek mellett a 
számítógépek is háttérbe szorítottak voltak. A számítógépek matematikai paradoxona, hogy bár a matematikából fejlődtek ki, információs forradalmat indítottak el, a matematikán kívül használják is óket megszületésük pillanatától; a matematikán belüli, alkotó jellegú felhasználásuk egyre csak váratott magára.

A számítógépek fejlődésével és elterjedésével lehetôvé vált azonban kísérletek nagy számú, gyors és hatékony elvégzése, azonnali kiértékelése; teret nyitva egy új matematikai szemlélet kialakulásának. Egyáltalán nem számítógéppel segített matematikáról van szó, sokkal inkább a számítógéppel megalkotott matematikáról. Az alkotás persze továbbra is a tanár feladata, de amint a számítógépekkel segített kísérletek az órai felfedezés organikus részévé lesznek, a kettô nehezen különíthető el, fóleg a diákok szemével nézve. Maga a problémafelvetés, és ezen át a definíciók, tételek, bizonyítások megalkotása mind-mind ezzel történik. A természettudományokban a kísérletek célja mindig is az elmélet igazolása volt, míg a matematikában eleddig csak a sejtések megszületésére vonatkozóan ismerték el szerepüket.

A számítógépes kísérleti matematika módszertana a következôkben foglalható Össze $[17,21]$.

(a) A rálátás és az intuíció segítése.

(b) Kapcsolatok és minták felismerése.

(c) A matematikai tartalom kézzelfoghatóvá tétele a grafikus megjelenítés lehetôségeinek kihasználásával.

(d) Sejtések megerôsítése és cáfolása.

(e) A bizonyításra érdemes gondolatok kiválogatása.

(f) Segítség az alkalmas bizonyítási módszerek megtalálásában.

(g) Számítások elvégzése.

(h) Analitikusan származtatott eredmények megerôsítése.

A fentiekben tulajdonképpen a matematikai alkotás folyamatát láthatjuk, lépésekre bontva, oly módon, hogy azok a számítógépes kísérletekkel elérhetók legyenek. Az elsô három pont ((a)-(c)) az intuíció, a következô kettő ((d)-(e)) a sejtés, az utolsó három ((f)-(h)) pedig a bizonyítás segítése. 
A következôkben bemutatunk egy, a kísérletek szerepét leíró modellt [17].

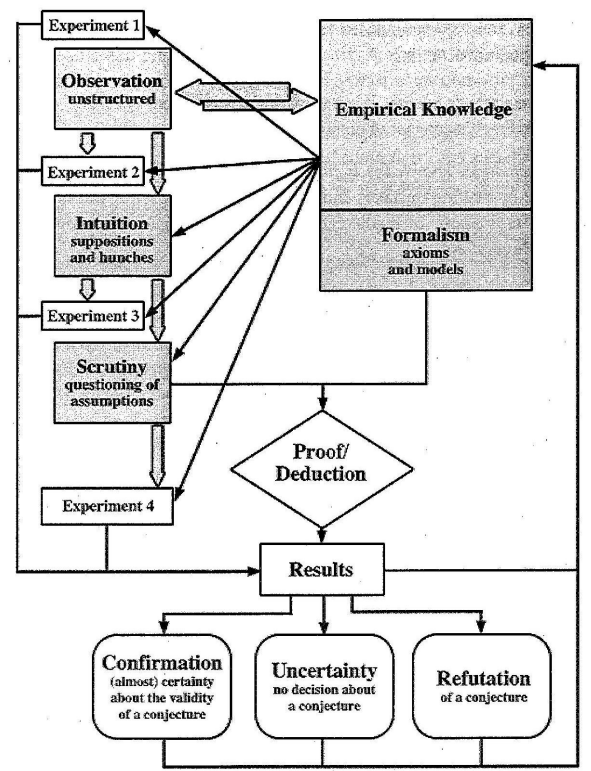

2.1. ábra. A kísérletek szerepe a tudományos felfedezésekben

A tapasztalati tudást szolgáló, és azt felépítő kísérletekbôl megfigyelések származnak, melyekból újabb kísérletek hatására intuitív feltevések lesznek. Ezekból a további, folyamatos kísérletezés hatására, az igazság monoton növelésével, sejtések alakulnak ki. Ezen sejtések további vizsgálata során, eljuthatunk a majdnembiztos megerôsítésig, illetve a sejtés bizonyításáig, esetleg cáfolásáig. A kísérletek a modell minden szintjével kapcsolatban vannak, így segítségükkel a köztes fázisok kihagyásával, a modell késôbbi szintjeire ugorhatunk. A deduktív bizonyítás a modellbôl kiemelhetô (elhagyható). Már meglévő tapasztalati tudásunk pedig felhasználható az új kísérleti eredményeink értékeléséhez, szintén segítve a modellben való elôrelépést. Ezen modellben leírtak játszódnak le tulajdonképpen mindenki fejében, amikor (matematikai) vizsgálatokat végez egy probléma megoldása érdekében.

Vizsgálataink során számos példán keresztül igyekszünk majd megmutatni ezen modell múködését, számítógéppel katalizálván kísérleteinket.

\subsubsection{Rövid történeti áttekintés}

A matematikai alkotás 2500 éves paradigmája, hogy az ember definiál egy fogalmat, megalkot egy vele kapcsolatos tételt, majd bebizonyítja azt [98]. Mára ez jelentôsen megváltozott, bár a kezdet kezdetén még úgy tûnt, nincs túl sok értelme kísérleteknek nevezni a számításokat vagy a képi ábrázolást. Mára azonban új megközelítések, új módszerek, új tudományágak alakultak ki hatásukra. A számítógépek számítási, tárolási, reprezentációs kapacitásának ugrásszerú megnövekedésével megváltozott ez a 
nézôpont is. A számítógépes kísérletek beférkőztek a „tiszta matematika” (pure mathematics) világába is, megváltoztatva ezzel a matematika egészéhez való hozzáállásunkat.

A terület az 1990-es években került a szélesebb körú érdeklődés középpontjába akkor, amikor az Amerikai Matematikai Társaság (AMS) a Notices of the AMS címú kiadványában egy rovatot indított Computers and Mathematics címmel. A rovatvezető kezdetben Jon Barwise majd Keith Devlin volt. Mindkettôjük célja az volt, hogy meggyốzzék a matematikus társadalmat arról, hogy a számítógép egy fontos és hasznos kutatási eszköz lehet. (A matematikusok többsége saját bevallásuk szerint is csak levelezésre és szövegszerkesztésre használta az annál sokkal többre hivatott számítógépét.) A kialakult vitában nem csak a számítógépben rejlő óriási számítási és reprezentációs potenciál került megvitatásra, de felmerültek az annak megbízhatatlanságával és ellenőrizhetetlenségével, valamint a logika kikezdhetetlen elvein alapuló bizonyítások szigorának és megkérdôjelezhetetlenségének fellazulásával kapcsolatos aggályok is. A vita egyik csúcspontjaként, 1993-ban Arthur Jaffe és Frank Quinn közzétették vélekedésüket, miszerint a matematikusokat, akárcsak a fizikusokat, ezentúl két csoportra, az elméleti és a kísérleti matematikusok csoportjára kell különíteni [151]. Ha nem is ennyire radikálisan, de a matematikusok többsége egyetértett abban, hogy befogadónak kell lenni a számítógépekkel, még akkor is, ha alkotó jellegú használatuk a matematikában a bizonyítás fogalmának, és ezen keresztül az egész matematikai filozófiának az újraértelmezésével jár. 1992-ben David Epstein, Silvio Levy és Klaus Peters, megalapította az Experimental Mathematics címú tudományos folyóiratot. (Experimental Mathematics, kiadja az A K Peters, Ltd, főszerkesztô Yuri Tschinkel.) A folyóirat mottója szerint az elmélet és a kísérlet elválaszthatatlanok. 1993 novemberében pedig Jonathan Borwein vezetésével megalapították Centre for Experimental and Constructive Mathematics (CECM) kutatóintézetet Kanadában, a Simon Fraser University berkein belül. Azóta számos összefoglaló mú [17, 18, 19] és a filozófiát terjesztô cikk [9, 21, 151, 83] jelent meg. A felderítô felfedezés (exploratory experiment) a fogalomalkotás elfogadott módjává vált, éppúgy mint a tény, hogy a számítógépek adják azt a kísérleti háttérországot a matematikának, amely a természettudományok esetében már évezredek óta megvolt.

Mára a számítógépek alkotó jellegú felhasználásának elfogadása elkerülhetetlenné vált tehát a „hagyománytisztelô”" matematikusok körében is. Az elsố nagy lépés e tekintetben a négyszín sejtés bizonyítása volt. Appel és Haken bizonyítása inkább csak számítógéppel segített volt, (computer-assisted proof) de a matematikusoknak el kellett fogadniuk, hogy nem minden bizonyítás olyan, mint egy költemény, néha meg kell elégednünk egy-egy telefonkönyvvel ${ }^{1}$ is. Az utolsó, döntő tény pedig talán Thomas Hale bizonyítása Kepler gömbpakolási problémájára. Hale a bizonyítást, mely a többszáz írott oldal mellett gigantikus hosszúságú számítógépes programot és számítást tartalmazott, 1998-ban nyújtotta be az Annals of Mathematics címú folyóiratnak. A folyóirat 2003-ban fogadta el a cikket (Thomas C. Hales. A proof of the Kepler con-

\footnotetext{
${ }^{1}$ Appel és Haken bizonyításával szemben nem csak a számítógép megbízhatatlansága volt a kritika, de az is, hogy a bizonyításuk olyan, mint egy telefonkönyv, holott, egy matematikai bizonyításnak minden esetben olyannak kellene lennie, mint egy költemény.
} 
jecture, Annals of Mathematics, 162(3), 2005), a bíráló bizottság vezetôjének, Fejes Tóth Gábornak azon megállapítása ellenére, miszerint a „bizonyítás 99\%-ban helyes”, de az összes számítógépes számítás helyességét nem garantálhatják [88]. Beteljesült tehát Doron Zielberger 1994-es jóslata, miszerint fennáll a lehetősége, hogy elfogadunk egy majdnem biztos állítást, ha az hozzáférhetô (pl. költségét tekintve); amennyiben tudjuk, hogy a teljes, szigorú bizonyítás megfizethetetlen költségekkel bírna [163].

\subsection{A kísérleti matematika alkalmazása az oktatás- ban}

„A nagy felfedezések nagy feladatokat oldanak meg, de nincs olyan feladat, amelynek megoldásához ne volna szükség valami kis felfedezésre." (PÓLYA GYÖRGY)

\subsubsection{Kísérletek és matematika}

A tanár, valamilyen érthetetlen oknál fogva ragaszkodik ahhoz, hogy diákjainak valami teljeset, kikezdhetetlent, véglegeset adjon. Az ismereteket ilyen, akadémikus jelleggel tárgyalva diákjainkat nem kíméljük meg ugyan a kudarcoktól, viszont megfosztjuk óket a felfedezés lehetőségétől, izgalmától. Pedig a felfedezés öröm.

\section{A feladat és a felfedezés (Pólya)}

Bármilyen apró, ... matematikai feladat megoldása erôfeszítést kíván és a felfedezés örömét adja [138].

Néhány év matematikatanítás után elérjük, hogy a diákok biztosak legyenek abban, hogy ốk a matematikában semmit sem képesek alkotni, elérjük, hogy diákjaink ne csak hogy ne értsék, ne is lássák értelmét, sôt ne is szeressék a matematikát; s hogy ezt a szemléletet adják tovább gyermekeiknek is. Dienes Zoltán szerint a gyerekek többsége sohasem jut el odáig, hogy megértse, mit is jelentenek azok a matematikai fogalmak, amiket használ.

A kísérletek szerepének alátámasztására elegendő csak Euler nevét említenünk. Ô volt az, aki rengeteg felfedezést tett a matematikában az indukció, azaz a megfigyelés, a merész sejtés és a briliáns igazolás segítségével. Ugyanakkor a tudományt gazdagító felfedezéseit csak akkor érezte teljesnek, ha ôszintén feltárta a hozzájuk elvezető gondolatokat is [137]. Azt pedig, hogy a kísérleteknek megkerülhetetlen szerepük van a heurisztika segítésében, Pólya és Lakatos óta tudjuk. Pólya szerint is a kísérletek jelentik a matematikai tudás legfóbb forrását, a kísérletek azok, melyek a megfelelő irányba terelik az intuíciót. 
A találgatás szerepe (Pólya)

A matematikus alkotó munkájának eredménye bizonyító okoskodás, egy bizonyítás, de ezt a bizonyítást plauzíbilis okoskodással, találgatással fedezik fel. Ha a matematikatanulás kicsit is tükrözi a matematikai felfedezést, akkor helyet kell kapjon benne a találgatás, a plauzíbilis következtetés [138].

Mindezen ismereteknek a kísérleti matematikával való összekapcsolása azonban eddig váratott magára. Éppen ezen kapcsolat feltárása, bemutatása ennek a dolgozatnak a célja. A számítógépek fejlődésével és elterjedésével lehetôvé vált kísérletek nagy számú elvégzése, nagy mennyiségú adat feldolgozása, adathalmazok manipulálása, valós idejû számítások elvégzése, animációk vizsgálata, melyek egyébként is elidegeníthetetlen részét képezik a tanulási folyamatnak. Most mindezek a XXI. század társadalmi elvárásainak megfelelő környezetben jelenhetnek meg. Valljuk, hogy kísérleteink segítségével integrálható egymásba a tradicionálisan külön kezelt felfedezés és igazolás.

Felfedezés és igazolás (Pólya)

Amint meggyôződtél arról, hogy a tétel igaz, kezdd el a bizonyítást [138]!

Pólya munkásságának egyik legfontosabb mondanivalója is éppen az, hogy a matematika nem azonos formális elméleteknek egy csoportjával, hanem elválaszthatatlan attól az emberi tevékenységtól, amellyel mi magunk hozzuk létre a matematikai vizsgálódás tárgyát. Ugyanakkor a számítógépek fejlődésével és elterjedésével lehetôségünk nyílik nagymennyiségú számítás, valamint kísérlet gyors és pontos elvégzésére, illetve ezek eredményeinek kiértékelésére, következtetések levonására. A számítógépek ezen, innovatív módon történô, alkotó jellegú felhasználásával, a Borwein által elindított kutatási módszer oktatásra való adaptálásával, a Pólya György által szorgalmazott heurisztika és kísérletezés végre a megérdemelt mértékú szerepéhez juthat a tanításban. A (közép)iskolások számára kitûzött, természetesen felmerülô, de ugyanakkor kutató jellegú problémák vizsgálata során a számítógép nem csak a szemléltetésben, de a problémafelvetésben, a fogalmak kialakításában, a sejtések megfogalmazásán és tesztelésén keresztül pedig a matematikai alkotás teljes folyamatában is segítségünkre lehet. A kísérlet és az elmélet elválaszthatatlanok. A tanulók maguk is felfedezôvé válhatnak és ez az egyik legfontosabb központi gondolat.

\section{Az intuíció szerepe (Pólya)}

Az intuíció sokkal hamarabb és kevesebb külső befolyásra jelentkezik, mint a formális érvelés. Ez utóbbit csak akkor értjük meg igazán, ha már a logikai csiszoltság viszonylag magas szintjére jutottunk el. Ezért a középiskolában jóval előbb kell hangsúlyoznunk az intuitív belátást, mint a következtetést [135]. 
Pólya szerint a tudományos módszer: kitalálás és ellenôrzés. („Tanítsuk meg a találgatást!") A gép mindkettőben segít. Lehetőséget ad arra, hogy a diák részt vegyen a probléma kitûzésében is. A Pólya-féle egymást követô fázisok elvében a felfedezés fázisa megelôzi a szavakba foglalást és a fogalomalkotást; módszerünkkel fogalmakat is alkothatunk, sôt segithet a szavakba öntésben is. A megfigyelés, sejtés, induktív érvelés hármasán keresztül segíti a plauzíbilis következtetést. A tanár tôkét kovácsolhat az órán keletkezett spontán felfedezésekból. A fentiek nem csak Pólya György, de Lakatos Imre, a bizonyítás és a cáfolat párhuzamos keresésén, a lokális és globális ellenpéldák vizsgálatán, az ún. torzszülöttek kizárásán alapuló heurisztika modelljét is modern köntösben teszik alkalmazhatóvá.

\section{Az intuíció szerepe (Lakatos)}

A fejlődô elméletben az intuíció járatlan, botladozik és hibázik. Nincs olyan elmélet, ami ne ment volna keresztül a fejlôdés ilyen szakaszán, sôt történeti szempontból ez a legizgalmasabb szakasz, s az oktatásban is ennek kellene a legfontosabbnak lennie. Euklidész ezért ... mind a kezdő fokú, mind a kreatív szintú matematikaoktatásnak a rossz szelleme [90].

Módszerünk spirális használatával nem csak a fogalmak kialakítására, de azok megerôsítésére, absztrahálására; esetleges cáfolatára is mód kínálkozik, mely tulajdonképpen nem más, mint Lakatos azon gondolatának, miszerint a matematikai fogalmak ugyanúgy fejlődnek, mint a természettudományok fogalmai, az oktatásban végre megjelenô hatékony alkalmazása.

A rigorózus, többség által korábban is inkább csak tudomásul vett, mintsem megértett bizonyítások háttérbe szorításával, de a bizonyítási igény megôrzésével és a magyar matematikaoktatás tradicionális erényeinek kiaknázásával (pl. problémamegoldó gondolkodásra nevelés) a problémák újfajta megközelítési és feldolgozási módjának lehetősége tárul fel.

A következôkben összefoglaljuk, hogy a kísérleti matematika elôzô pontban (2.2.1. fejezet) részletezett módszertana míly módon adaptálható az oktatásba. (A további fejezetek javarészt ezek részletes kifejtésérôl szólnak.)

A tanár a tanulásszervezés operatív szempontjai tekintetében például a következóképpen és a következô formákban használhatja ki a kísérleti matematika által nyújtott lehetôségeket. Lehetôvé, illetve könnyebben kivitelezhetôvé válik a
(a) csoportmunka;
(b) projektmunka;
(c) differenciálás;
(d) aktív tanulói részvétel;
(e) játékalapú tanulás;
(f) kutatás alapú tanulás.

Módszertani hasznok: 
(1) (nyílt végú) feladatok dinamikus létrehozása;

(2) ellenőrzési lehetôség;

(3) a matematika alkalmazási lehetôségeinek bemutatása;

(4) kollektív tapasztalatszerzés lehetôvé tétele;

(5) dinamizálás didaktikai lehetôségeinek kihasználása;

(6) problémaérzékenység növelése;

(7) bizonyítási igény kialakítása;

(8) eddig megközelíthetetlen problémák tárgyalásának lehetôsége;

(9) matematikai eszközigény csökkentése;

(10) gyengébb képességúek felzárkóztatása, bevonása;

(11) a matematika szórakoztatóvá tétele;

(12) folyamatos kérdésfelvetés segítése;

(13) társadalmi elvárás kielégítése;

(14) induktív, deduktív, kritikai és problémamegoldó gondolkodás segítése;

(15) a problémamegoldási ciklus (minden megoldott probléma szabállyá válik, amely késôbb más problémák megoldására szolgál) segítése;

(16) megoldás folyamatos próbálgatással, szukcesszív approximáció módszere.

A problémamegoldás, az órai matematikai felfedezés következô elemeinél nyújt segítséget módszerünk:

(i) fogalmak megalkotása;

(ii) fogalmaink megszilárdítása;

(iii) fogalmaink absztrahálása;

(iv) modellalkotás;

(v) megfigyelés;

(vi) analógia;

(vii) mintafelismerés: teljes indukció;

(viii) mintafelismerés: proof without words;

(ix) stratégiák kialakítása;

(x) bizonyossági szint növelése az igazság monoton növelésével;

(xi) indoklás megfogalmazása;

(xii) hibás bizonyítások kreálása;

(xiii) példák és ellenpéldák együttes hatása;

(xiv) bizonyítási módszer megtalálása;

(xv) bizonyítás lépéseinek megalkotása;

(xvi) ellenôrzés.

A dolgozatban példákat láthatunk az utolsó két felsorolás létjogosultságára vonatkozóan is. 


\subsubsection{A jelenlegi helyzet áttekintése: a bizonyítások súlya a matematika érettségi vizsgán}

A magyar matematikaoktatás hagyományosan problémaorientált, ugyanakkor elméletközpontú. A tételek ellenőrzése inkább történt bizonyításaik számonkérésével, mintsem alkalmazásuk ismeretének tesztelésével. A bizonyítások számonkérése mindig is része volt a matematika érettséginek. (Gondoljunk csak a „Zöld könyv” - Összefoglaló feladatgyújtemény matematikából I. fejezetére [126].) (Az persze más kérdés, hogy a tanulók hány százaléka értette meg ezeket a bizonyításokat, s hányan voltak azok, akik csak bemagolták azokat, a biztos pontok reményében.) Mára azonban, részben az 1. fejezetben elemzett paradigmaváltásnak köszönhetôen, a hangsúly az alkalmazások irányába tolódott. A középszintû érettségin nem kérünk számon bizonyítást. Ennek egyenes következménye, hogy a legtöbb iskolában (középszinten) nem is tanítanak bizonyítást, sôt van olyan, ahol ez egyenesen tilos(!). A 2010. május-júniusi érettségi idôszakban a matematikából érettségizóknek mindössze a 2,7\%-a választotta az emelt szintû érettségit (89889 vizsgázóból 2467), így mindössze ők adtak számot bizonyítási ismereteikből [115]. (Külön megemlítendő, hogy az összes tantárgyat tekintve, ezen alacsony arány ellenére is a matematikát választják a legtöbben emelt szinten.) Már amennyiben igényt tarottak az érettségi 150 pontjából az ezért (a tétel helyes kimondásáért és bizonyításáért együttesen) járó 6 pontra. (Ez az emelt szintú matematika érettségi összpontszámának 4\%-a.)

\subsubsection{Kísérletek és bizonyítások}

A legtöbb tanár úgy érezheti, hiába tanítjuk a bizonyításokat a szokásos deduktív módon, a diákok többsége nem jegyzi meg azokat, de még ha meg is jegyzi, meg nem érti. S ez nem csak a középiskolában van így. Ha valami megmarad, azok az általános iskolából származó aritmetikai ismeretek mellett, a legtöbbet használt összefüggések, tételek. Nem tartozik ide azonban a tételek érvényességi köre, s fóleg nem a bizonyításuk. Személyes tapasztalat, hogy egy nagyváros „elit” gimnáziumának informatika tagozatos, s az érettségi után is informatikai területen továbbtanuló diákja, alig egy évvel az érettségi után már nem tudta elkülöníteni egymástól a koszinusztételt, és a koszinusz szögfüggvény definícióját. Mindezek azt mutatják, hogy iskolai szinten még mindig rosszul állunk a bizonyítás fogalmához, annak tanításához, illetve a bizonyításokkal kapcsolatos elvárások megállapításához.

Felmerül hát a kérdés, nem lenne-e elég a (közép)iskolában - az átlagos képességú és nem feltétlenül már a kezdet-kezdetén a matematika iránt elkötelezett - diákok számára egy deduktív, a saját szerkezetéból adódóan (teljes mértékben) befogadhatatlan szemlélet helyett, egy kísérletezésen alapuló, induktív szemléletú matematikát átadni, még ha ezzel nem is jutunk el a logikusok által is elfogadott bizonyításig, csak a majdnembiztos állításokig, esetleg a bizonyosság kívánt szintjéig?

A kérdés elsôre talán eretneknek hat, de mégsem az, legalább is addig, amíg nem tisztázzuk egész pontosan a bizonyítás fogalmát, illetve azt, hogy mit is várhatunk el 
egy adott korú gyerektôl, az életkori sajátosságai, érdeklődési területe stb. figyelembevételével, bizonyítás címén. Mindezen elvárásokat persze szigorúan össze kell hangolni a kimeneti elvárásokkal (érettségi, felvételi, kompetenciamérés), mert ezek között jelenleg éles ellentét feszül.

A fenti kérdések megválaszolása rendkívül bonyolult, hosszadalmas, s nem is célja jelen dolgozatnak, éppen ezért itt csak néhány kapcsolódó, gondolatébresztô megállapítást teszünk. A szerzô véleménye szerint a probléma szinte megoldhatatlan, hiszen mire megnyugtató álláspontra jutnánk a kérdésben, ami a rajta dolgozók sokféle, egymásét még csak hírbôl sem ismerô nézôpontja miatt eleve kizárt, addigra az elvárások oly mértékben megváltoznak, hogy a kidolgozott válasz irrelevánssá lesz. A bizonyítás iskolai keretek közé is beilleszthetô fogalmáról, szerepérôl számos, átgondolásra érdemes álláspont létezik.

\section{A bizonyítás fogalma (Hardy)}

Olyan, hogy matematikai bizonyítás, nem létezik; végül is nem tehetünk mást, csak kiemelünk; ... a bizonyítások ... dagályos szóvirágok, céljuk a lélektani hatás, szemléltetô ábrák az oktatásban, eszközök a diákok képzeletének serkentésére [67].

A bizonyítás fogalma (Wilder)

A bizonyítás intuitív sugallataink ellenôrzésére használt eljárás [164].

\section{A bizonyítás fogalma (Pólya)}

A bizonyítások kapcsolatokat teremtenek a matematikai tények között, s elősegítik, hogy emlékezetünkben megőrizzük őket [135].

Azt, hogy egy fogalom definíciója függ a befogadók életkori sajátosságaitól, érdeklődési körüktôl, a szükséges szinttôl, azaz az elvárásoktól, teljesen elfogadott. Ez az, amit sok más összetevôvel együtt spirális felépítésnek nevezünk. Gondoljunk csak például a hatványozás fogalmára. A hatvány bevezetésekor, az általános iskola 7. osztályában nem más, mint egy azonos tényezókból álló szorzat rövidítésére használt eljárás, jelölés. Láthatjuk, hogy bizonyos múveletek egyszerúen elvégezhetôk a kitevôk segítségével, melyek ekkor még pozitív egészek. Ezek után a középiskola kilencedik osztályában kerül elő a nulla kitevô a $0^{0}$ problematikájával. Itt már szükségünk van bizonyos „megállapodásokra”. A nulla kitevôs hatvány mellett bevezetjük a negatív egész kitevôs hatvány fogalmát is; a korábban megismert azonosságokat nem firtatjuk, rábízzuk a permanencia-elvre. (Szerencsésebb persze, ha mi magunk fedeztetjük fel az új hatványfogalmat, mint az egyetlen logikus, és lehetséges kiterjesztést, épp a fenti, nem feltétlenül néven nevezett teljesen természetes elvárás szem előtt tartásával.) Utána látszólag nem foglalkozunk hatványokkal, tizedik osztályban ismét elókerül 
a nyolcadik osztályos definíció, és a kilencedik osztályos függvény után a négyzetgyök fogalma. Ezúttal már tárgyaljuk az azonosságokat, sôt kiterjesztjük a gyökvonás fogalmát, jön az $n$-edik gyök. Tizenegyedik osztályban elôször bevezetjük a racionális törtkitevôs hatvány fogalmát, majd ezt összekapcsoljuk az n-edik gyök fogalmával. Kiderül, a gyökvonás tulajdonképpen hatványozás. Az exponenciális függvény tárgyalásakor, szintén a permanencia-elv és a kétoldali közelítés segítségével vezetjük be a valós kitevôs hatványt, hallgatólagosan. Korrekt bevezetése a folytonosság tárgyalásáig várat magára, s a szerző matematika szakos és másodéves volt, amikor a komplex kitevôs hatvány fogalmát megismerte.

A fentiek mondanivalója az, hogy ha megkérdezünk valakit a hatvány, vagy a gyök fogalmáról, akkor életkorától függóen más és más választ fogunk kapni. Egy-egy tétel bizonyítása esetében ugyanezt azonban a matematikus társadalom nem fogadná el (a tanár társadalom már annál inkább); talán félnek, hogy összedól a matematika építménye Euklidész szigorú bizonyítása nélkül. Az új szemlélet terjedése szerencsére már tetten érhetô.

\section{A bizonyítás relativitása (William P. Thruston)}

Drámaian világosan látom, hogy a bizonyítás mily mértékben relatív: mindig egy speciális közegben bizonyítunk, egy speciális közönség számára [88].

\section{A bizonyítás relativitása (René Thom) ${ }^{2}$}

Hiszem, hogy a bizonyítás szigora relatív, sohasem teljes. Függ az olvasó előismereteitôl és elvárásaitól [88].

A kérdést tovább árnyalja a számítógépek elterjedése, számolási határaik, sebességük, reprezentációs lehetőségeik robbanásszerú fejlődése, valamint (az alkotó jellegû) használatukra vonatkozó elvárások beépülése a társadalmi elvárások közé.

Szintén elgondolkodtató a szerzô következô, személyes tapasztalata. A dolgozathoz kapcsolódó cikkek $([72,110])$ publikálása során a folyóiratok (The College Mathematical Journal, International Journal of Computers for Mathematical Learning) szerkesztőitôl rendre az a kérés érkezett, hogy töröljük a cikkből a bizonyításokat, de legalább is azokat csupán vázlatos formában, pusztán a főbb ötletek vázolásával tegyük közzé.

A fentiekben leírtak a dolgozatban többször elő fognak kerülni. Az ismétlés azonban nem öncélú. Szerepe a hangsúlyozás, a kiemelés, a figyelem felhívása arra, hogy módszerünk használata, vagy akár csak szemléletünk apró megváltoztatása mennyire más színben láttathatja a matematikai megismerés egy-egy problémáját.

\footnotetext{
${ }^{2}$ René Thom (1923-2002), francia Fields-érmes (1959) matematikus
} 


\title{
3. fejezet
}

\section{Felfedezések a matematikaórán}

\author{
„Úgy irtam, hogy az olvasó mindig észrevehesse a tanultak belsô inditékait, \\ sốt lássa a felfedezés forrásait is, és úgy érthessen meg mindent, mintha \\ azt saját maga fedezte volna fel." (G. W. LEIBNIZ)
}

Mai szemmel nézve Leibniz gondolatai utópisztikusnak hatnak. Manapság a matematikai cikkek deduktív felépítésú erôdítmények, melyek még csak véletlenül sem engednek választ találni arra a kérdésre, hogy az adott eredmény hogyan született. Mintha a matematikusok titkolni akarnák azt. A cikkek olvasóinak maguknak kell rájönniük arra, amit a cikk írója felfedezett. Az olvasó gyakorlatilag újra kénytelen megalkotni az eredményt. Sajnos a tankönyvek többsége is ilyen, tiszta matematika (pure mathematics), tehát sokkal inkább tudomány, mintsem tantárgy, felfedezésre váró érdekes ismeretlen módjára láttatja a matematikát. Jól megmutatkozik ez abban is, hogy a felfedeztetô jellegú feladatok száma az iskola 5. osztálya után a tankönyvekben elenyészô. A tankönyvek mellett az órákon is sokkal inkább kellene támaszkodni az intuícióra, s ezt minden lehetséges eszközzel támogatni, mintsem megpróbálni felépíteni a matematikát az üreshalmazból.

Azt azonban, hogy a diákjaink is mindenre maguktól jöjjenek rá, nem várhatjuk el tôlük. A felfedezéseket és a kísérleteket a tanárnak kell irányítania. A tanár az információ (frontális) forrásából a felfedezéseket segítô társsá lép elô.

Az alábbiakban erre, a tanulók aktív, alkotó részvételével kivitelezhetô matematikai felfedezésekre mutatunk néhány példát; egyelőre számítógépek használata nélkül. 


\subsection{Felfedezések számítógép nélkül}

„Már régóta megvannak az eredményeim, csak még nem tudom, hogyan jussak hozzájuk." (GAUSS)

\subsubsection{Müveleti tulajdonságok}

Ötödik osztályban kerülnek elő elôször absztrakt formájukban az algebrai kifejezések. A tanulók absztrakciós készsége ebben a korban még nem minden esetben van olyan szinten, hogy az $(a+b) c=a c+b c$ típusú azonosságokat (múveleti tulajdonságokat) a maguk absztrakt formájában el tudják sajátítani. A sokszor minden áron kizárólag absztrakt formában elsajátíttatni, és ezáltal elsajátítani kívánt azonosságok tanulási nehézségei, illetve gyakran kudarca után nem csoda, hogy sokaknál késóbb is gondot okoz a hasonló kifejezések kezelése. Segítségül hívva azonban egy egyszerú geometriai modellt - a téglalap eddigre már mindenki által ismert területszámítását - a megértést segíthetjük egy ábrával, például a következô módon.

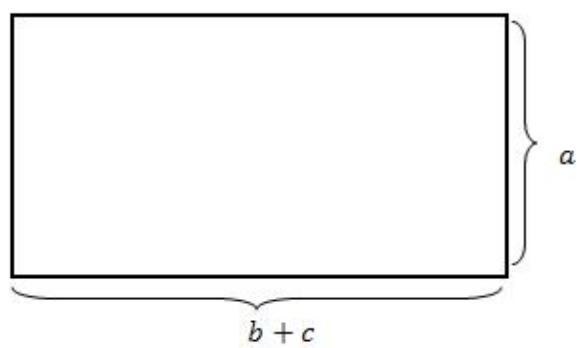

(a)

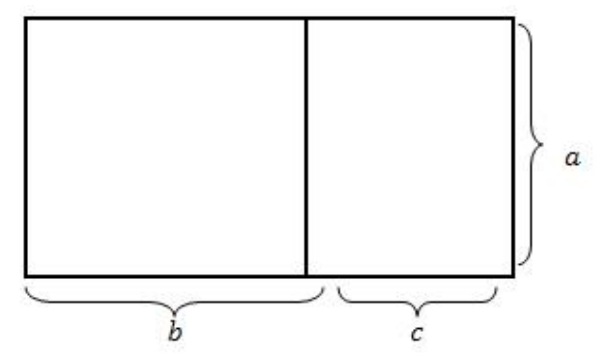

(b)

3.1. ábra. Múveleti tulajdonságok: $(b+c) a=b a+c a$

A bal oldali ábrán egy téglalap látható, mely oldalainak hossza $b+c$ illetve $a$, így területe $t=(b+c) a$. Vágjuk fel téglalapunkat a jobb oldali ábrán látható módon két téglalapra. Így két téglalapot kaptunk, melynek oldalai $a$ és $b$, illetve $a$ és $c$ hosszúságúak. A két rész ${ }^{1}$ területének összege megegyezik az eredeti téglalap területével, vagyis: $(b+c) a=b a+c a$.

3.1. Megjegyzés. Az ilyen és hasonló ábrák hasznosságát szélesebb körben való alkalmazhatóságuk is dicséri. A fenti ábra átjelölésével például az $(a \pm b)(c \pm d)$ típusú összefüggések mindegyike tárgyalható.

3.2. Megjegyzés. Érdekes kérdés, és ez tulajdonképpen a dolgozat további részén is végigvonul, hogy elfogadjuk-e ezt bizonyításnak? Igényel-e egyáltalán bizonyítást,

\footnotetext{
${ }^{1}$ Általában fontos persze, hogy mérhetô részekre vágjunk, gondoljunk csak a (Hausdorff)-BanachTarski paradoxonra.
} 
fôleg ebben az életkorban bármi is, ami ilyen könnyen „igazolható” az intuitív belátás útján? Miért is bizonyítjuk, ha a fenti összefüggés szerepel a valós számok múveleti axiómái között? Elfogadhatjuk-e, hogy a diákok eddigre már ismerik a téglalap területszámítását? A problémát tovább árnyalja az a tény, hogy ezt, és a többi múveleti tulajdonságot jóval korábban, már a kezdet kezdetén, az (írásbeli) összeadás, szorzás tanítása/tanulása során intuitív módon, aktívan használjuk [145].

\subsubsection{Nevezetes azonosságok - egy példa}

A kilencedik osztályos tananyag jelentôs része a nevezetes szorzatokkal, a szorzattá alakítás különbözô módszereivel, az algebrai törtekkel való múveletekkel foglalkozik. Ezen ismeretek eszközszintú birtoklása elengedhetetlen feltétele a továbbhaladásnak, tanulásuk viszont nehéz. Ennek egyik oka, hogy tanításuk, az alkalmazásokat is beleértve, az előzőekhez hasonlóan, teljesen formális.

Az elôzô, általános iskolában használható ábrák apró módosításával középiskolában is jól használható segítséget kaphatunk, fenntartva ezzel a tanításban rendkívül fontos folytonosságot.

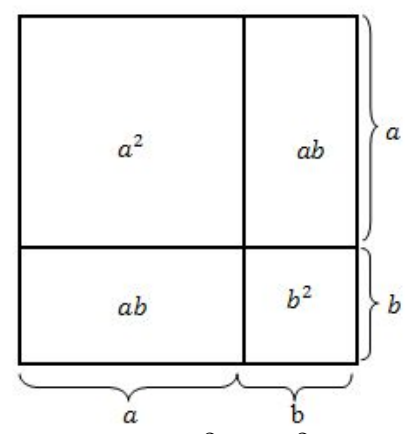

3.2. ábra. $(a+b)^{2}=a^{2}+2 a b+b^{2}$

Az ábrán látható négyzet területének kétféle módon történô felírásával az

$$
(a+b)^{2}=a^{2}+2 a b+b^{2}
$$

azonossághoz jutunk.

A fenti módszer, az ún. kétoldali közelítés, illetve összeszámlálás módszere eredményesen használható a matematika szinte bármely területén [109].

3.3. Megjegyzés. Elegendő hát ennyi, vagy feltétlenül szükséges a „minden tagot minden taggal" formalizmusa? Mivel a bizonyítás fogalma különösen a számítógépes módszerek elterjedésével nem csak az iskolában (az iskolai matematikában) de a tudományban is tisztázásra vár, meg kell elégednünk annyival, hogy a választ minden esetben a kimenet elvárásai, igényei, illetve az aktuális tanulócsoport sajátosságai, 
lehetôségei adják meg. Másrészrôl viszont ismert, hogy a tanulók egy részének gondolkodása inkább vizuális, míg másoké inkább formális, így az oktatásban mindkét megközelítés párhuzamos használata javasolt.

\subsubsection{Nevezetes összegek - egy példa}

Az elsô $n$ pozitív egész szám összegének zárt alakjára vonatkozó Gausstól származó szép bizonyítást szinte mindenki ismeri. Sokan úgy gondolják, hogy míg Gauss osztálytársai kiszámolták, addig Gauss bebizonyította a kérdéses összefüggést.

Ezt tanulmányozva, a (teljes indukciós) bizonyítás ellenére is felmerülhet diákjainkban a miért, egész pontosan a miért éppen ez kérdése. A kérdés, és általában az ilyen típusú kérdések megválaszolhatók, s ezáltal az összefüggés lényege, a formula mögötti valódi matematika(i tartalom) is megvilágítható. A megvilágítás még élesebb képet ad abban az esetben, ha az összefüggést maguk a diákok fedezik fel, aktívan megalkotva saját matematikájukat. Piaget szerint is a diákok jobban megértik a cselekvést, mint a szavakat.

Az elsố $n$ pozitív egész szám összege természetes módon szemléltethetô a következô módon. Helyezzünk el kavicsokat (egységnyi területû négyzeteket) az alábbi ábrán látható módon.

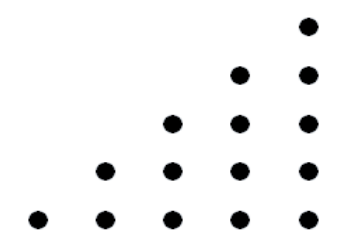

(a)

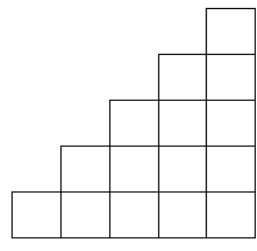

(b)

3.3. ábra. $1+2+3+\ldots$

Amit kaptunk, az egy $n \times(n+1)$-es téglalap fele.

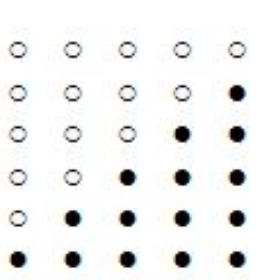

(a)

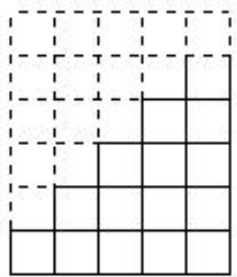

(b)

3.4. ábra. Felfedezés: A pozitív egészek összege és a téglalap fele 
A fenti elrendezés kavicsainak száma (a síkidom területe) kétféle módon is meghatározható. A kavicsokat (a négyzetek területét) oszloponként összegezve a kavicsok száma (a terület): $1+2+\ldots+n$. A kavicsokat (a négyzetek területét) egyszerre, a fél téglalap segítségével összeszámolva $\frac{n(n+1)}{2}$ számú kavicsot (nagyságú területet) kapunk. Így a kavicsok számának (a síkidom területének) kétféle módon történô meghatározásával kapjuk:

$$
1+2+\ldots+n=\frac{n(n+1)}{2} .
$$

3.4. Megjegyzés. Magának a fenti ábrának, illetve ezáltal a mögöttes összefüggésnek a megközelítése is apró lépésekben, induktív módon javasolt. Rajzoljuk fel elôször az 1, $1+2,1+2+3, \ldots$ összegnek megfelelő ábrákat, s hagyjuk, hogy a diákok maguk fedezzék fel az összefüggést. (Itt tulajdonképpen a bizonyítást adó formális teljes indukció absztrakt voltának megszüntetése történik azáltal, hogy szabad teret engedünk az intuíció szárnyalásának.) Ha elakadnak, jelen helyzetben a tanár feladata nem az információ közlése, hanem a felfedezés segítése. Ez történhet például egy jó kérdéssel: Mi történik, ha két szomszédos ábrát ügyesen egymásra fordítunk?

3.5. Megjegyzés. A fenti módszer lehetôséget kínál arra is, hogy szakítsunk a rugalmatlan, a tanulókat lekötni, illetve a társadalmi elvárásoknak megfelelni egyre inkább képtelen, frontális tanítási módszerrel. A diákok kisebb csoportokban is dolgozhatnak a problémán, a csoporton belül egymás munkáját segítve, de lehetôségünk van arra is, hogy megfelelő előkészítés után projekt jellegú, nagyobb lélegzetvételü otthoni feladattá konvertáljuk a problémát.

3.6. Megjegyzés. A fenti ábrák elforgatásával bevezethetô a háromszögszám fogalma, s tárgyalható jónéhány kapcsolódó tulajdonság, azonosság is.

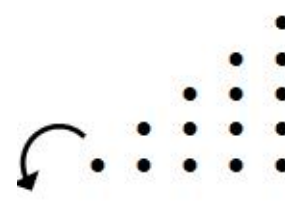

(a)

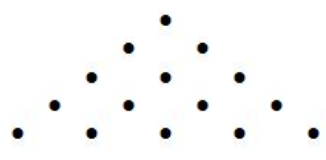

(b)

3.5. ábra. Felfedezés: A pozitív egészek összege és a háromszögszámok

\subsubsection{Felfedezések a geometriában - mérés és szerkesztés}

Az elemi geometriában, gyakorlatilag az életkori sajátosságoktól függetlenül, nincs meggyôzőbb a diákok számára, mint a mérés és a szerkesztés. Valójában a koordinátageometria sem tesz mást, mint ezek pontatlanságát és esetlegességét helyettesíti (a 
pontos) számolással. Saját, többszörös megerősítést nyert tapasztalat, hogy a középiskolai elemi síkgeometria tanításának végén, 10. osztályban, 15-16 éves korban is, még mindig egy-egy jó ábra, szerkesztés, tehát jelen környezetben az intuitív belátás után képtelenség a deduktív következtetés logikáján alapuló bizonyítást magát, vagy akárcsak annak szükségességét elfogadtatni. Ez az a terület, ahol a személyes tapasztalatok által szerzett bizonyosság elválaszthatatlan a bizonyítástól, tanulói szemmel nézve szükségtelenné téve azt.

A következôkben arra mutatunk néhány példát, hogyan lehet mégis, az összefüggések felfedezése által a bizonyosság kívánt szintjére eljutni, megalapozván, sôt esetleg észrevétlenül létre is hozva a bizonyítást.

\subsubsection{A háromszög belsô szögeinek összege I.}

A következô ábrák egy, a háromszöggel végzett kísérlet kulcsfontosságú pillanatképei [60].

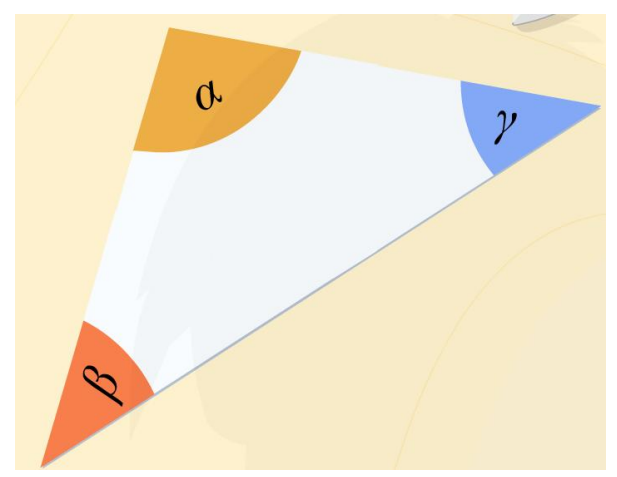

(a)

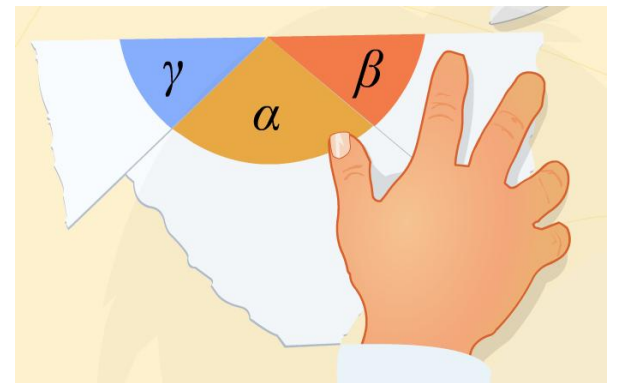

(c)

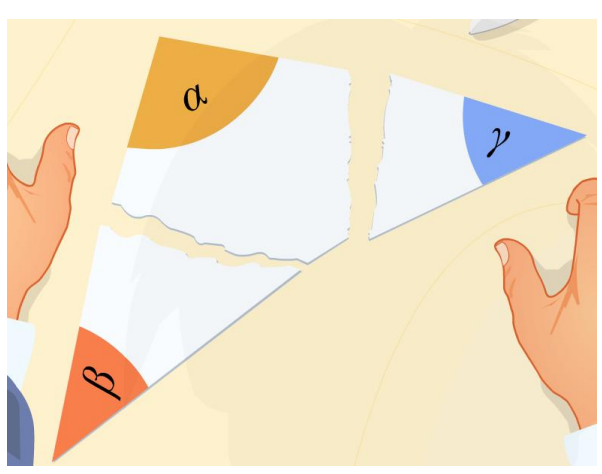

(b)

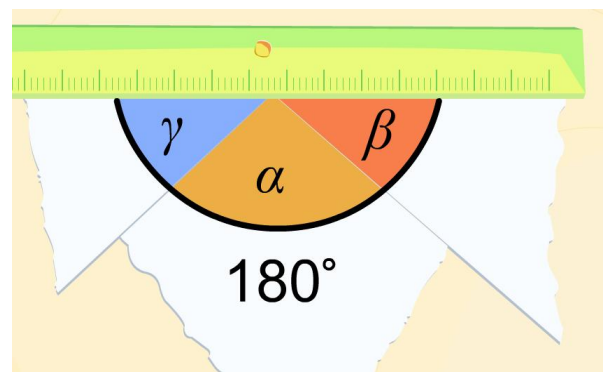

(d)

3.6. ábra. Bizonyítás(?) - A háromszög belsố szögeinek összege I.

A fenti megközelítés (bizonyítás?) jelentőségét az adja, hogy a tanulók aktív, alkotó jellegú részvételével jön létre. Lehetőséget ad a cselekedtetésre; a Tépd szét!, Illeszd össze!, Mit tapasztalsz?, s végül de nem utolsó sorban a Miért ezt kaptuk? jellegú megközelítésre, egy deduktív szemléletû felépítés helyett. 
3.7. Megjegyzés. Ebben a konkrét esetben, és hasonló esetekben szintén, sokkal hatékonyabb, ha a tanulók maguk vágnak ki háromszögeket. Így lesz aki hegyesszögú, derékszögû illetve tompaszögû háromszöggel dolgozik. Akad majd a kivágott és széttépett háromszögek között egyenlő szárú, sőt szabályos is. Így segíthetjük az önálló tapasztalatszerzésen alapuló belátást. A számos kísérlet azonos eredménye vezethet el a felfedezéshez. Az önálló felfedezés izgalma segítheti a bizonyítási igény kialakulását is. Akár ezzel az egyszerú példával is jól szemléltethető, hogy a matematikai alkotás egyik leghatékonyabb módja az aktív cselekvésen alapuló tapasztalatszerzés.

\subsubsection{A háromszög belsố szögeinek összege II.}

A következô ábrákon bemutatott kísérlet szintén bármiféle formalizmus nélkül alkalmas a fenti összefüggés bizonyítására. Külön előnye, az előzôhöz hasonlóan, hogy nem kell elôre megmondanunk, mit is szeretnénk a kísérlettel bebizonyítani, így a felfedezés öröme teljes maradhat. Jelen esetben a háromszög oldalai mentén eltolt, s csúcsainál elforgatott gyufaszál fejének állása adja a bizonyítást, egyállású és váltószögek fogalmának használata nélkül [60].

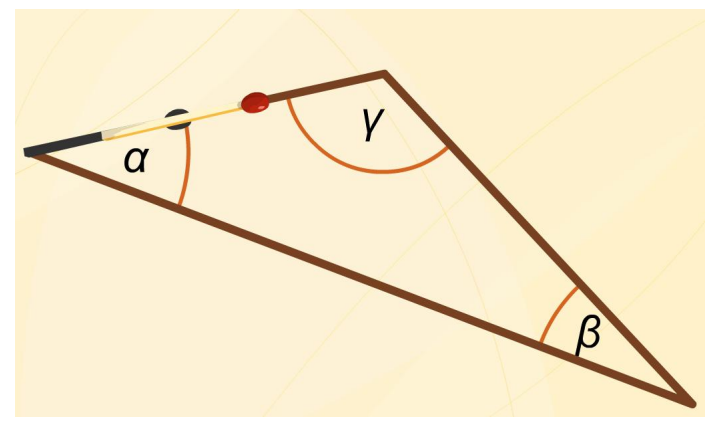

(a)

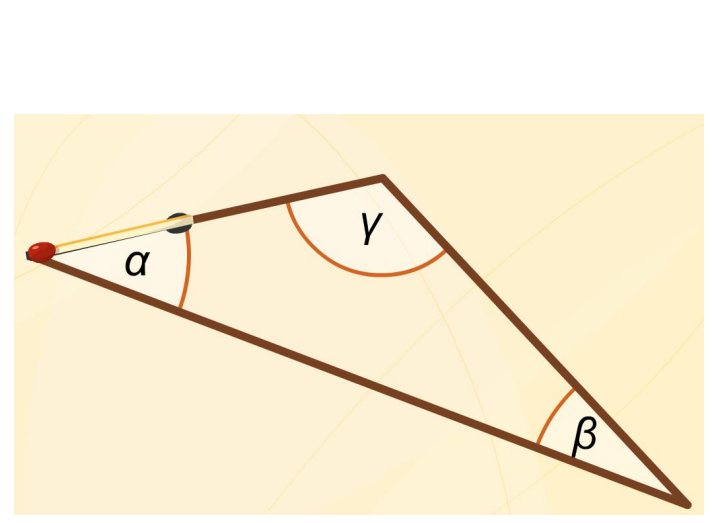

(c)

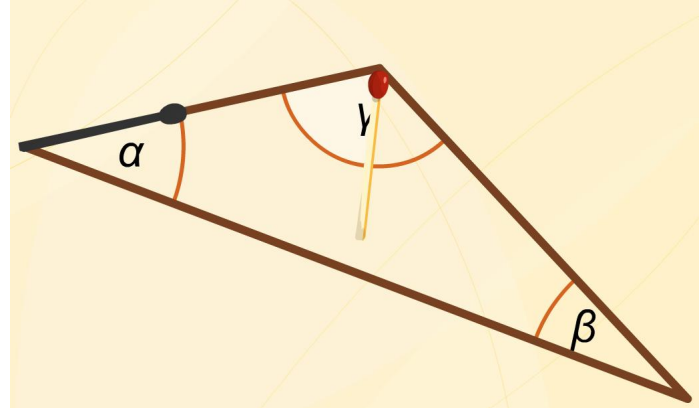

(b)

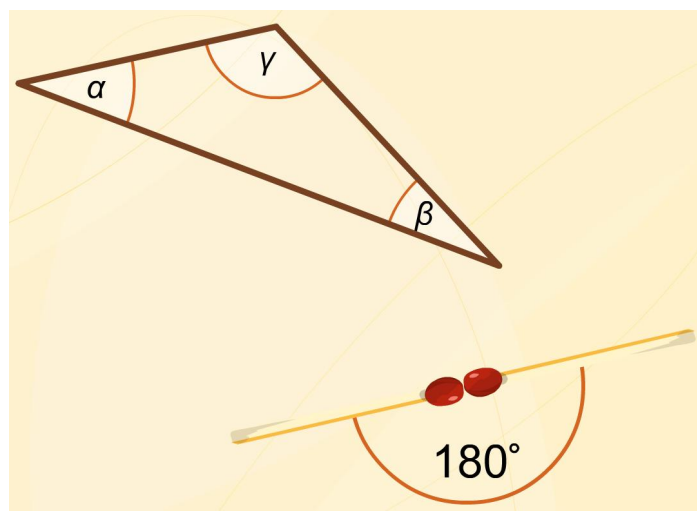

(d)

3.7. ábra. Bizonyítás(?) - A háromszög belsô szögeinek összege II. 


\subsubsection{A háromszög belsô szögeinek összege III.}

A következô ábrák szintén egy szemléletes bizonyítást adó sajátkezúleg is kivitelezhetô kísérlet pillanatképei. Az alábbi ábra képei a Mathematica programcsomag segítségével készültek [169]. A kísérlet kivitelezéséhez számítógép természetesen nem szükséges, esetleges használatának elônyeirôl a (3.3.4.) fejezetben lesz szó.

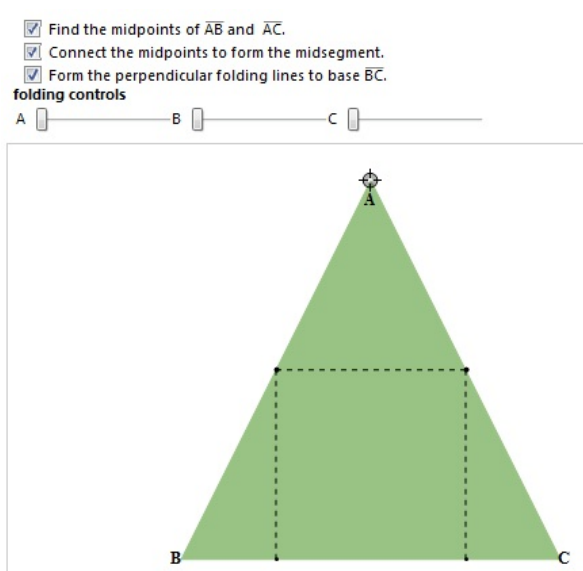

(a)

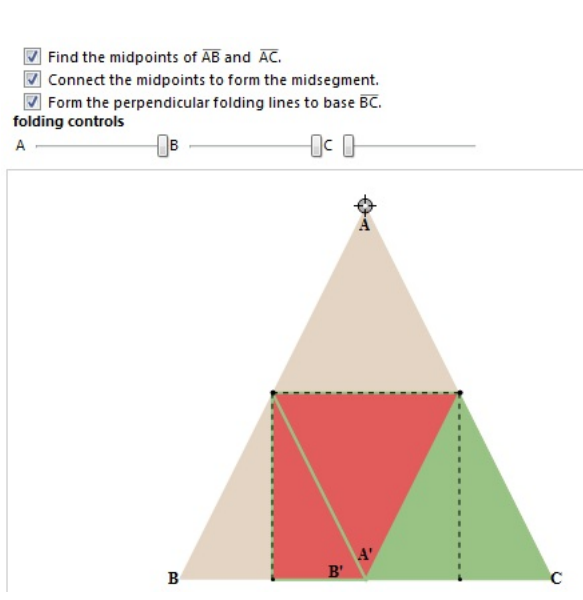

(c)

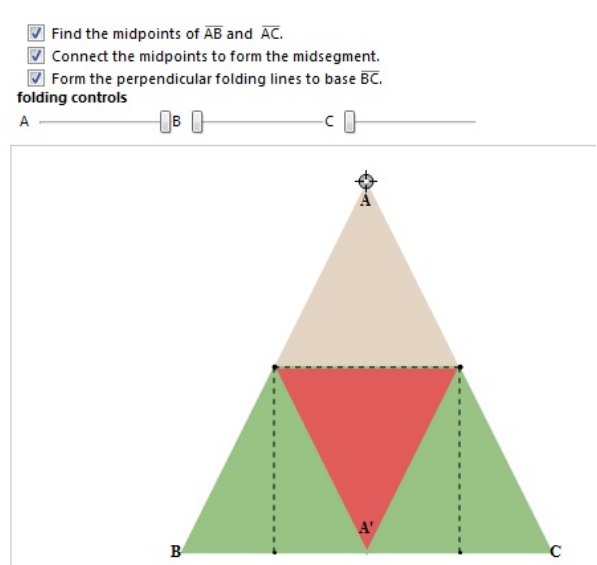

(b)

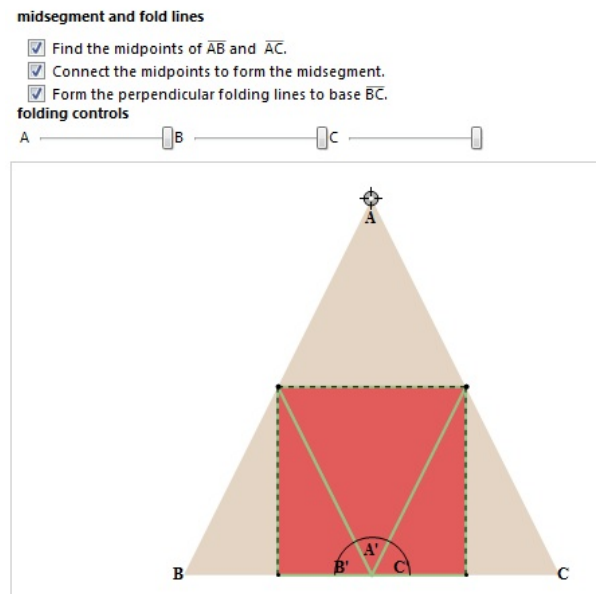

(d)

3.8. ábra. Bizonyítás(?) - A háromszög belsô szögeinek összege III.

3.8. Megjegyzés. A fenti bizonyítással bevezethetô a háromszög középvonalának fogalma is. 


\subsubsection{A Thalész-tétel}

A diákok számára tökéletesen meggyôzô, s ezáltal a többségük számára a további bizonyítást szükségtelenné és értelmetlenné tevő bizonyítási módszer Thalész tételére is néhány, saját kézzel kivitelezett szerkesztés és mérés. Egy körben egy átmérôt behúzva, annak két végpontját a körvonal több, szabadon választott pontjával összekötve, a keletkezett kerületi szögeket szögmérô segítségével lemérve azonban, fôleg a fellépó pontatlanságok okán, nem tudunk eljutni a bizonyosság szinte megdönthetetlen szintjére. A kérdés nyitott marad, vajon tényleg bármely kerületi pont jó választás, vagy csak mi voltunk szerencsések? Jó példa ez hát arra, hogy a kívánt bizonyossági szint eléréséhez itt már érdemes a számítógépek segítségét igénybe venni (3.4.4. fejezet).

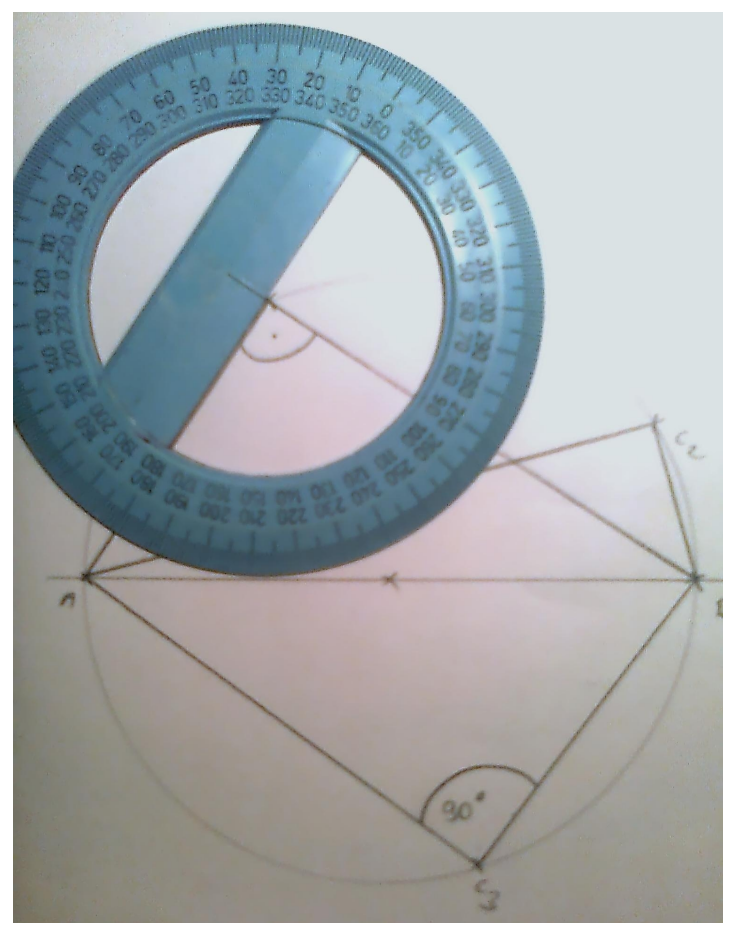

3.9. ábra. Thalész-tétel - Bizonyosság vagy bizonyítás?

A mérés és megfigyelés, a kísérleteken keresztüli tapasztalatszerzés nem csak a geometria, de a valószínúségszámítás területén is segíthet, sokszor még formálisan nehezen megközelíthetô problémák esetében is. Az alábbiakban erre láthatunk egy példát. 


\subsubsection{Egy valószínüségi modell}

Tekintsük a következô feladatot:

3.9. Feladat. Két játékos, Anna és Balázs, a továbbiakban A és B egy szabályos dobókockával játszik. A játékot A kezdi és a kockát felváltva egyszer-egyszer feldobva az nyer, aki először dob hatost. Mi a valószínúsége annak, hogy A nyer?

Tekintsünk először egy „hagyományos ” megoldást:

Megoldás. Jelölje $A$ azt az eseményt, hogy A nyer. Keressük $P(A)$ értékét. Vezessük be a $P\left(A_{n}\right)$ jelölést, mely jelentse azt, hogy $\mathrm{A}$ az $n .\left(n \in \mathbb{N}^{+}\right)$lépésben nyer. Ekkor $P(A)=\sum_{n=1}^{\infty} P\left(A_{n}\right)$. Könnyen látható, hogy $n$ csak páratlan szám lehet, hiszen $\mathrm{A}$ csak páratlanadik dobásra nyerhet. Legyen $n=2 k+1(k \in \mathbb{N})$. Ekkor $P\left(A_{1}\right)=\frac{1}{6}$, $P\left(A_{3}\right)=\frac{1}{6}\left(\frac{5}{6}\right)^{2}$, hiszen ahhoz, hogy A a 3 . dobásra nyerjen annak kell teljesülnie, hogy az általa dobott elsố, és a B által dobott második dobás ne legyen hatos, míg az A által dobott 3. dobás éppen hatos legyen. Hasonló meggondolásokkal adódik, hogy $P\left(A_{n}\right)=\frac{1}{6}\left(\frac{5}{6}\right)^{n-1}$. Így a keresett valószínúséget a következő összeg formájában tudjuk felírni:

$$
\sum_{n=1}^{\infty} P\left(A_{n}\right)=\sum_{k=0}^{\infty} P\left(A_{2 k+1}\right)=\sum_{k=0}^{\infty} \frac{1}{6}\left(\frac{5}{6}\right)^{2 k}=\frac{6}{11} .
$$

3.10. Megjegyzés. A fenti megoldásban használtuk (kénytelenek voltunk használni) a végtelen mértani sor fogalmát, mely a jelenleg életben lévố hivatalos tananyagot tekintve csak emelt szinten kerül tárgyalásra 11. osztályban. Ezzel ki is zártuk a tanulók 96-98\%-át a megértésből.

Éljünk most egy más megközelítéssel.

Megoldás. Tekintsük a következô ábrát.

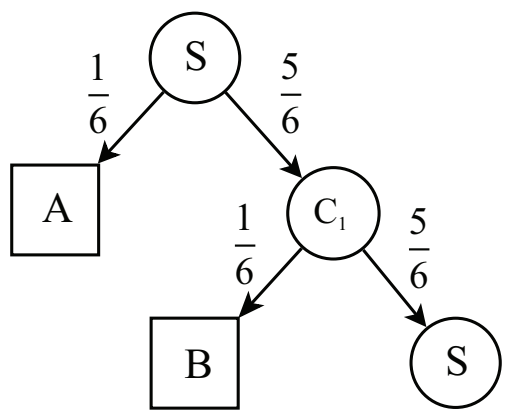

3.10. ábra. Dobás az elsô hatosig 
Itt $S$ jelöli a start állapotot, innen A dob, aki $\frac{1}{6}$ valószínúséggel dob hatost, így jutunk a bal oldali $\mathrm{A}$, azaz $A$ nyert állapotba, illetve $\frac{5}{6}$ valószínúséggel nem hatost dob, így a jobb oldali $C_{1}$ állapotba jutunk, ahonnan $\mathrm{B}$ dob. Ha hatost dob, nyert (B állapot), ennek valószínúsége most is $\frac{1}{6}$, ha pedig nem hatost dob, akkor ismét $\mathrm{A}$ következik, visszajutottunk tehát az $S$ állapotba. Most tulajdonképpen A-nak a start állapotból való nyerésének valószínúségét keressük, jelölje ezt $P_{S}(A)$. Analóg módon jelöléseket bevezetve a többi állapotra is, a következő egyenletrendszerhez juthatunk.

$$
\begin{aligned}
P_{S}(A) & =\frac{1}{6}+\frac{5}{6} P_{C_{1}}(A) \\
P_{C_{1}}(A) & =\frac{5}{6} P_{S}(A)
\end{aligned}
$$

ahonnan $P_{S}(A)=\frac{6}{11}$ adódik [104].

A második módszer elônye nem csak az, hogy nem használja például a végtelen sor fogalmát, s ezáltal szélesebb kör (akár általános iskolások) számára megközelíthetôvé teszi a megoldást, hanem elsôsorban a megközelítés kézzelfogható jellege. A valószínúségi probléma lényegét ragadja meg az ábra, a játékot ténylegesen követhetôvé, játszhatóvá teszi. A játék során a gyerekek maguk találhatják meg az egyes átmeneti valószínúségeket, elsôsorban tapasztalati úton. Maguk jöhetnek rá az egyes állapotok egymáshoz, s a kérdéses valószínûséghez való viszonyára, sôt tulajdonképpen számos játékon keresztül szerzett tapasztalataik után ők maguk rajzolhatják fel a fenti folyamatábrát.

3.11. Megjegyzés. A fenti két módszer ötvözésével, a kétoldali közelítés módszerét használva a végtelen mértani sorok elméletének ismerete nélkül is meg tudjuk határozni a fenti sor összegét. Sôt, a paraméterek változtatásával más mértani sorok is összegezhetôk, így akár azok összegének általános alakja is felfedezhetô. Lehetôségünk van például a lépések számának várható értékének hasonlóan egyszerú meghatározására. Számos, a fentiekhez hasonló probléma, s az ide kapcsolódó részletes módszertani elemzés megtalálható a szerző [104] cikkében (Attila Máder. Heads or Tails Gambling - What Can Be Learned about Probability?, Teaching Mathematics and Computer Science, 6(1), 15-41, 2008.).

\subsubsection{Módszertani összefoglaló}

A fejezetben bemutattunk néhány példát a tanulói felfedezések számítógép felhasználása nélküli támogatási lehetôségeire. Az ismert problémák szokásostól eltérô tárgyalási módja új lehetőségeket vet fel. Egy-egy ábra felrajzolása (3.1.2.), illetve közös létrehozása, vagy a szokásos tanári kérdések megváltoztatása ösztönzóleg hathat diákjainkra. Láthattuk, hogy egy kis ötletességgel az itt bemutatott módszerek is alkalmasak nem csak egy adott probléma, de akár egy egész témakör tárgyalására (3.1.3.). A felfedezések alkalmasak lehetnek egy-egy új terület automatikus, természetes bevezetésére 
is (3.6. megjegyzés). A tanári irányítással végzett tömeges tanulói kísérletek segítségével lehetôvé válik a kollektív tapasztalatszerzés (3.1.5.-3.1.8.). A kísérletek segítésével bevezethetünk új fogalmakat (3.8. megjegyzés), de akár el is kerülhetjük azok halmozását (3.1.6.). A tömeges tanulói kísérletek kiválóan álcázhatók játéknak is (3.1.9.), így alkalmasak a játékos formában történő ismeretszerzés minden előnyének kihasználására.

\subsection{A tanár megváltozott szerepe}

Az információrobbanás oktatásra gyakorolt legfontosabb hatása a tudás fogalmának átértékelődése volt. A lexikális tudás értékét vesztette, helyette az információs tengerben való eligazodás, a rendelkezésre álló információk felkutatása, összekapcsolása és hasznosítása bír értékkel. Többé már nem a tanár az egyetlen, sốt nem is az elsôdleges információforrás.

\subsubsection{IKT - Infokommunikációs technológiák az oktatásban}

„Az olyan ember, aki nem ért a számitógéphez a XXI. században analfabétának fog számítani." (TELLER EDE)

A XXI. század tanárával szemben természetes elvárás, hogy ismerje és használja a kor követelményeinek megfelelően az új infokommunikációs technológiákat (IKT (ICT)). A legtöbb esetben az ezekhez szükséges továbbképzések a tanárok többsége számára nehezen elérhetô, elsôsorban anyagi okok miatt. A kötelezô tanórák magas száma, az iskolák technikai felkészületlensége csak súlyosbít a helyzeten.

A múveltség egyik új fokmérôje a digitális írástudás, ami a tradicionális tudás, a számítógépes, valamint az információs múveltség szintézise. Napjaink egyik legfontosabb, legtöbbet emlegetett kérdése, hogy a modern információs és kommunikációs technológiák hogyan, mennyire terjedtek el, illetve, hogy ezeket az eszközöket milyen mértékben tudja a lakosság alkalmazni, hasznosítani, valamint az, hogy ezen eszközök milyen mértékben váltak a hétköznapi élet, a kultúra elfogadott elemeivé.

Mindezek tekintetében ugyan az elmúlt években a magyar adatok javultak, azonban európai összehasonlításban ez még csak elegendônek sem mondható. Egy 2007-es, az Európai Unió 25 tagállamát vizsgáló Eurostat felmérés szerint Magyarország az egyik legrosszabbul teljesítô ország ezen a területen. Az IKT kompetenciák és digitális írásképesség mérésére kifejlesztett - a teljes lakosságot vizsgáló - összesített digitális írástudás index $\left(\mathrm{COQS}^{2}\right)$ alapján Magyarország Lengyelországgal együtt az utolsók

\footnotetext{
${ }^{2}$ Communicating with others (by e-mail and other online methods);

Obtaining (or downloading) and installing software on a computer;

Questioning the source of information on the Internet;

Searching for the required information using search engines.
} 
között szerepel. E tekintetben az EU(15) átlaga 0,81, míg Magyarországé 0,3. De nem csak a teljes lakosság, hanem a fiatalok digitális írástudása is jelentôsen elmarad az uniós átlagtól [113]. A következô ábra egy SIBIS (Statistical Indicators Benchmarking the Information Society) GPS 2002 felmérésból származik [143].

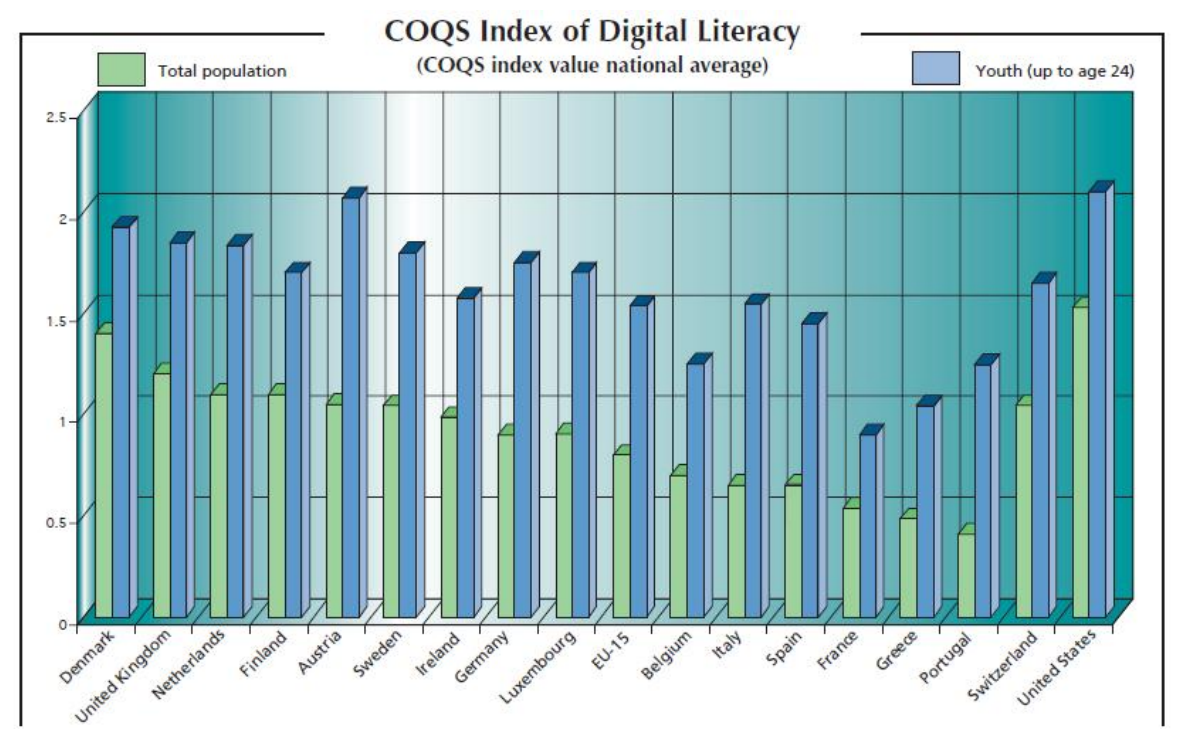

3.11. ábra. Digitális írástudás - COQS index

A jövôképet tovább rontja, hogy Magyarországon az információs technológiai kiadás mindössze a GDP 2,4 \%-a; míg például Ausztriában, Csehországban vagy Észtországban ez az érték meghaladja a 3\%-ot [113].

Az információs társadalomba való bekapcsolódás szempontjából meghatározó az oktatás szerepe. Ezért is kiemelkedően fontos az iskolák digitális felszereltsége, a tanárok infokommunikációs ismerete, illetve az új technológiák alkalmazásának igénye, valamint lehetôsége a tantermekben. Hazánk helyzete a 100 diákra jutó internettel rendelkezô számítógépek tekintetében európai szinten megfelelô. A kedvezô iskolai eszközellátottságunkat azonban beárnyékolja, hogy nagyon alacsony az elmúlt években az oktatás során számítógépet használó tanárok aránya, különösen az általános iskolában. Magyarország az uniós a sereghajtók között szerepel az IKT és digitális írástudás területén. Mindössze az iskolákkal, oktatással kapcsolatos felméréseknél érjük el az uniós átlag színvonalat. Az elmúlt évek pozitív hazai tendenciái ellenére változatlanul az alapinfrastruktúrákról, hozzáférési problémákról lehet beszélni, miközben az Európai Unió 2006-os direktívái már a digitális írástudás, az „intelligens” e-szolgáltatások, a befogadó információs társadalom témaköreit emelik ki [69]. 


\title{
3.2.2. Digitális bennszülöttek és digitális bevándorlók
}

\author{
„Amikor a fiadat oktatod, a fiad fiát is oktatod.” (ỐSI BÖLCSESSÉG)
}

Felnövốben van a sokak által csak digitális bennszülöttnek ${ }^{3}$ emlegetett generáció. Ôk azok, akik életében már végig jelen volt a számítógép, az internet, így a legnagyobb természetességgel nyúlnak a digitális eszközökhöz, azok használatát organikus folyamatként élik meg, legyen az egy PC, laptop, telefon, vagy valamely, csak virtuálisan elérhetô forrás. Az óket nevelô generáció tagjai, akik nem születettek bele a digitális eszközök világába, a digitális bevándorlók. Nekik mindössze arra volt (van) lehetôségük, hogy bizonyos szintig megtanulják ezen eszközök használatát, s így mint olyanok, nem is szolgálhatnak mintául a digitális bennszülöttek számára, hiszen mindaz ami a bennszülötteknek természetes, a bevándorlóknak kemény munkával tanult új kihívás. Nemhogy mintául nem szolgálhatnak számukra, de még a tempót is nehezen veszik fel velük. Legalábbis számos erre vonatkozó oktatásszociológiai felmérés ezt mutatta ki. A digitális bennszülöttek jellemzô tulajdonsága, hogy gyorsak, s ennek következtében türelmetlenek. Nem értik például, miért is kell bizonyos információkat, adatokat megtanulni, amikor azokhoz egyetlen kattintással hozzá lehet jutni. A generáció tagjai mire elvégzik az egyetemet átlagban 10000 órát töltenek videojátékokkal, 20000 órát tévénézéssel, s mindössze 5 000(!) órát olvasással [139]. Ennek következtében szövegértési képességük rossz, értő olvasásra egyre kevésbé képesek. (Hasonló negatív hatás figyelhetô meg a redukált elektronikus kommunikáció hatására a helyesírás esetében is.) Előnyben részesítik az ábrákat a szöveggel szemben, ugyanakkor egyetlen dologra nem tudnak hosszú távon koncentrálni, hiszen szeretik párhuzamosan feldolgozni az információkat. Éppen ezért esetükben nem határolódik el a tanulás és a szórakozás, s szintézisükből kialakult a szórakoztató tanulás (edutainment). Marc Prensky abból kiindulva, hogy egy magára valamit is adó digitális bennszülött soha nem olvasná el egyetlen program felhasználói kézikönyvét sem, helyette inkább a program használata közben tanulja meg annak használatát, egyenesen azt gondolja, hogy a leghatékonyabban számítógépes játékokon keresztül lehet a digitális bennszülötteket tanítani (digital-game based learning (DGBL)), ez a játékalapú tanulás. Számukra az információ minden esetben változatos formában: képben, hangban, videóban, szövegben érkezik. Ezzel a bevándorlók a legtöbb esetben egyszerúen nem tudnak mit kezdeni. Ök a hagyományos, lineáris elvú tanítás hívei, nem hiszik, hogy a véletlen elérés, a gyorsan váltakozó rövid ideig tartó impulzusok hatékonyak lehetnének a tanulásban.

Az infokommunikációs lehetôségek térnyerése jelentôsen megváltoztatta a diákok iskolával szemben alkotott elvárásait is; ezek a diákok tehát már nem azok, akikre a jelen oktatási rendszert tervezték. Sôt, nem pusztán arról van szó, hogy a digitális bennszülöttek másképp gondolkodnának, hanem a legújabb neurobiológiai kutatások szerint agyuk szerkezete is másképp alakult. Gondolkodásuk nem lineáris, hanem hypertext alapú, szökellő. Figyelmük nem folyamatos, hanem lökésszerú és megosztott.

\footnotetext{
${ }^{3}$ A fogalmat Marc Prensky használta először. Közkedvelt elnevezés még a screenagers, illetve a $\mathrm{N}($ et)-generáció (Generation N) is [139].
} 
Oktatásunk egyik legnagyobb problémája éppen ez, hogy a digitális világ nyelvét csak akcentussal bíró tanárok fáradoznak azon, hogy a nyelvet anyanyelvi szinten beszélôket valamire megtanítsák [139]. Néhány éve még például szenzációnak számított egy-egy színes ábrákkal teli, anyanyelvúek által írt nyelvkönyv. Manapság pedig szinte kifogástalanul meg lehet tanulni egy nyelvet pusztán az internet segítségével. Az információkkal telezsúfolt statikus CD-k pedig olvasatlanul végzik a fiók mélyén [140].

A digitális bevándorlók és bennszülöttek közötti folyamatosan növekvô különbség nagyságrendi voltát mutatja, hogy míg a digitális bevándorlók épp csak tanulgatják az internet használatát, addig a digitális bennszülöttek már réges régen az Internet of Things (IoT) rendszerében élnek. Az IoT világában gyakorlatilag bármely „dolog” képes bármely másikkal kapcsolódni. A hatféle B (bármivel, bárkivel, bármikor, bárhol, bármilyen szolgáltatással, bármilyen hálózaton keresztül) korlátlan lehetôséget kínál felhasználói számára.

A számítógéppel, illetve a számítógépes játékokon keresztül kialakult, fejlesztett gondolkodási képességeik közé tartoznak például a megfigyelések, a gyors alkalmazkodás képessége, a szabályok gyorsabb kikövetkeztetése, a hipotézisek megfogalmazásának képessége, illetve az, hogy a diákok azokat a folyamatokat részesítik elônyben, melyek aktív cselekvéssel járnak. Éppen ezeket próbáljuk meg kihasználni a felfedezések előtérbe állításával. A fentiekben vázolt szakadék áthidalására lehet segítségünkre példul az e-learning néven ismertté váló keretrendszer, módszertani fogásként pedig a felfedezések előtérbe helyezése, az önálló kutatás (játékokon keresztül történô) órai szintú szimulálása. Ez utóbbi felépítése során bátran támaszkodhatunk a kutatás-alapú tanulás/tanítás módszereire, elôzményeire.

\subsubsection{E-learning}

A diákok (digitális bennszülöttek) jórésze kifogásolja is, hogy tanárai nem, vagy csak érdektelen módon használják az internetet. (Magyarországon a 14-17 évesek 94 százaléka internethasználó, míg az óket tanító 30-60 éves korosztálynak mindössze a 45 százaléka használ internetet. A legfóbb különbség azonban a használat aktivitásában van [146].) Az internetben rejlő oktatási lehetôségek egy megvalósulása az e-learning. Bár magára az e-learning-re általánosan elfogadott definíció eddig nem született, hatásait máris érzékelhetjük. Elônye a hagyományos oktatással szemben többek között a földrajzi távolságok áthidalása. A diákoknak nem kell órákat utazni egy-egy óra miatt, s ezzel nem csak az ökológiai lábnyomuk mérete csökkenthetô, de az órák térben és idôben szabadabban szervezhetók. Nem állhatja útjukat még egy-egy járvány sem [87]. Középiskolákban is vannak már ennek kezdetleges jelei, illetve egyre több egyetem használ egyelôre még csak kiegészítésként VLE-rendszert (Virtual Learning Environment). Ilyen például a Moodle, vagy a Szegedi Tudományegyetem által használt CooSpace. Az amerikai egyetemek oldalain barangolva pedig egyre gyakrabban botlunk bele komplett kurzusok elektronikusan is elérhető anyagaiba, s akár teljes előadássorozatok videó anyagait is megnézhetjük, esetenként a videóhoz csatolt magyarázó 
szövegekkel, ábrákkal. Találkozhatunk továbbá például Skype-on tartott konferenciákkal, előadásokkal is.

Az online módszereknek számos előnye van. A segédanyagok mindegyike elektronikus úton előállított, így gond nélkül, környezetbarát módon sokszorosítható, a kurzusok anyaga könnyen rögzíthetô. A digitális bennszülöttek párhuzamos tanulási módszereinek kedvez, hogy egyszerre több téma tárgyalásába is be lehet kapcsolódni. (Az e-learning alapú oktatás egyik formája az aszinkron tanulás, mely során a tanuló a tananyagot a saját tempójában dolgozza fel, szemben a szinkron tanulással, melyben a képzés egy meghatározott idóben zajlik, bár a tanulóknak itt sem kell feltétlenül egyazon helyen tartózkodniuk. A saját ritmusban való haladás lehetôsége szintén a hatékonyságot növelheti.) A kurzus résztvevôinek száma tetszôlegesen nagy lehet, a mindennapi kommunikációban megszokott online közösség a tanulásban is egymás segítségére lehet. A gyengébb képességűek kevéssé érzik magukat frusztrálva; a tanulási folyamat részesei egyenrangú félként vehetnek részt a foglalkozásokon. Az online módszerek egyik hátránya viszont épp a fizikai távolság meglétéból ered. A tanár nem tudja metakommunikatív eszközeit érvényesíteni, a személyes jelenlétébôl eredő előnyöket kihasználni, s a diákok ezt kihasználván könnyebben figyelmen kívül tudják hagyni az instrukciókat is. (Egy szigorú következetességgel múködő rendszerben ennek hatását azonban minimálisra lehet csökkenteni.) Meg kell még említenünk, hogy a villámgyors reakciókat igénylő kontakthelyzetek kezelésére a tanár csak személyes jelenlét esetén képes. A munka értékelése szinte kizárólag csak írásban történhet, ami csökkenti az azonnali, szóbeli dicséret motiváló erejét [63].

3.12. Megjegyzés. Az Európai Unió 2001-ben fogadta el az eEuropa program részeként az eLearning-csomagot, melynek célja, hogy a digitális technológia elônyeit az európai polgárok rendelkezésére bocsássa [162].

\subsubsection{A tanár új szerepe}

\section{Az információs társadalom hatása}

Az információs társadalom által támasztott igényeknek való megfelelési kényszer hatására a tanárok szerepe minden eddiginél mélyrehatóbb változás előtt áll. A tanár szerepe a tények és kész megoldások tanítása helyett egyre inkább a kompetenciák és jártasságok átadása, az élethosszig tartó tanulásra (lifelong learning) való felkészítés lesz. A tanár a továbbiakban csupán egyike a tanulót körülvevô számtalan információforrásnak, sôt, maga is folyamatosan tanul a rendszerben. Sokkal inkább tekinthetô az információáramlás menedzserének, mintsem az információ forrásának. Sokan a tanárok legfőbb feladatának, már egészen kisiskolás kortól kezdve, a diákok az információk megszưrésére alkalmassá tevô kritikai képességekkel való felruházását tartják. A mindent tudó, porosz szellemú tanárt felváltja a digitális világban eligazodni képes, új, tanácsadó szellemú tanár, aki a tanulókat aktív, önálló, de ugyanakkor közös felfedezésekhez segíti. 


\section{A kérdések szerepe}

A matematika felfedeztetés-központú oktatásában megváltozik a kérdések szerepe, jellegük átalakul. Korábban a tanári kommunikációt a téma kifejtésére irányuló, illetve a probléma felvezetését megcélzó, adat megállapításra vonatkozó, valamint a fogalom jelentésére, megnevezésére vonatkozó kérdések uralták [96]. Az egyes kérdések megközelítése a hagyományos szemlélet szerint ugyanis leggyakrabban zárt úton, a Bizonyitsuk be, hogy... típusú problémakitûzéssel történik. Ez azonban nézôpontunk szerint valójában nem is problémakitüzés. Kérdésfelvetésnek, gondolatébresztésnek, önálló, szabad alkotásra való sarkallásnak végképp nem nevezhetô. A többletismerettel rendelkezô felsőbbrendúségével ily módon megfogalmazott feladatok a legtöbb mai diák számára nehezek. Nehezek, mert idegenek a számukra, idegenek, mert értetlenül állnak elótte, hiszen manapság, amikor folyamatosan publikálnak a weben, önálló alkalmazásokat hoznak létre, minden korábbinál jobban igénylik, hogy részesei legyenek a (matematikai) alkotási folyamatnak is, a tanulás számukra ne passzív befogadás, hanem aktív alkotás legyen. Ezen (teljesen természetes módon) felmerülő és jogos, de ugyanakkor a hagyományos módszerekkel kielégíthetetlen igények sora által keltett kétely árnyékában nem beszélhetünk (matematikai) problémamegoldásról, csak kizárólag formális tevékenységrôl. A formális tevékenységeknek persze fontos szerepük van bizonyos készségek, algoritmusok, eljárások eszközszintú elsajátításában, de a teljes tanulási folyamatot mégsem lehet pusztán rájuk építeni. Mindemellett tudjuk, hogy senki számára nem közölhetünk egy, a meglévô fogalmainál magasabb szinten lévő fogalmat definícióval [145]; s itt implicit módon ez történik. Ezekre a kérdésekre a legtöbb formális bizonyítás nem ad valódi, a gyerekek számára is megnyugtató, a probléma lényegét feltáró választ, s a további kérdésfelvetést sem segíti, annál is inkább nem, mert tulajdonképpen nem is beszélhetünk kérdésfelvetésrôl. Minden esetben célunk kellene legyen az összefüggés, és általában az új ismeret felfedeztetése. Ha a diák maga jön rá az adott összefüggésre számos sikeres - és persze ezt megelőzendően számos értékes tapasztalattal szolgáló sikertelen - próbálkozás után, magáénak érzi azt, hiszen ô maga találta. A (kísérleti) fizikus, a kémikus folyamatosan kísérletezik, s a kísérleteiból származó tapasztalataiból alkotja meg új ismereteit. S kísérletezik a maga módján a matematikus is. Tanításunkban ennek sajnos vajmi kevés nyoma van. A zárt végú feladatok korlátozó, az önálló gondolatokat kizáró merev keretei helyett teret kell engednünk a nyitott kérdések szabadságának.

\section{A sejtések szerepe}

A tanár elsődleges szerepe tehát a felfedezések segítése, a sejtések motiválása. A korábbi, konkrét példák esetében ez azt jelenti, hogy segíthet például a téglalapok összeillesztésében (3.1.3. fejezet), vagy a kavicsok megfelelő alakzatba történô elrendezésében. Szerepe sokszor „csak” annyi, hogy felírja a köztes lépések eredményét a táblára (3.1.9. fejezet), vagy felhívja a figyelmet arra, amire figyelni kell, például, hogy milyen irányba mutat a gyufa feje (3.1.6. fejezet). A jó sejtések mindig is nagy hajtóerôt 
jelentettek a matematikában. Ezeket azonban nagyon jól kell megfogalmazni, s a jól megfogalmazott sejtéseket az eredményekkel azonos szinten kell kezelni. Erre a matematika történetében számos helyen találhatunk utalást. Gondoljunk például arra, hogy Fermat sejtése a Fermat-számok prím voltáról hamisnak bizonyult ugyan, de kutatásokat, felfedezéseket ösztönzött.

\section{A számítógépek szerepe}

A sejtések legfontosabb forrása éppen a számítógépek által is lehetôvé tett, illetve kiterjesztett kísérleti matematika. Azt, hogy ennek létjogosultsága van még a tudományban is, nem csak a korábban ismertetett Borwein-féle vonal mutatja, de jól példázza többek között a Siemion Fajtlowicz amerikai matematikus által létrehozott Graffiti nevú program, mely gráfelméleti sejtéseket generál az adatbázisában megtalálható gráfok közös paramétereit vizsgálva. Egyik sejtése például a kommunikációs bonyolultságelmélet egy kulcskérdéséhez kapcsolódik, s bár magára a kérdésre Alon és Seymour negatív választ adott, egy gyengített változata mind a mai napig nyitott [98].

Kísérleteikkel a diákok tulajdonképpen (önálló) kutatásokat végezhetnek, így a kísérleti matematika számos ponton kötődik a kutatásalapú tanuláshoz.

\subsection{Felfedezések a számítógép eszközszintü felhasz- nálásával}

„A középszerú tanár magyaráz. A jó tanár indokol. A kiváló tanár demonstrál. A nagyszerú tanár inspirál." (WILliam ARTHUR WARD)

A következôkben olyan, bárki számára egyszerúen és jogtisztán hozzáférhetô alkalmazásokat mutatunk be, melyek múködtetése pusztán felhasználói ismereteket igényel.

\subsubsection{Bevezetés}

Jelen helyzetben a tanároknak egy új, folyamatosan megújuló és fejlődô rendszerben kell tudásukat, s módszereiket átértékelni. Itt is, mint minden tanulási folyamat során, kiemelten fontos a fokozatosság. A korábbiakban technikai ismereteket nem igénylô példákon mutattuk be a módszert múködés közben. Ebben a részben a számítógépet eszközként használjuk majd. Minimális felhasználói ismeretekkel (internet, egyszerú alkalmazások) rendelkezvén is látványos kísérleteket végezhetünk. Többségében weboldalakról, már elkészített webes alkalmazásokról, illetve telepítést nem igényló programokról van szó. Elônyük, hogy gyorsan előhívhatók, elôzetes elkészítést nem igényelnek, így használatuk nem vesz több időt igénybe, mint egy nélkülük való órára 
történő felkészülés. Az itt bemutatott programok telepítést sem igényelnek, mobil eszközökről is futtathatók, így a tanár még a rendszergazda segítségére sincs rászorulva. A következô példák egy konkrét cél érdekében, módszertani alapossággal válogatott lehetôségek, így természetesen nem a teljesség igényével állnak itt.

A példák válogatását a számítógép eszközszintû felhasználásával történô mind szélesebb körú felfedeztetési lehetôségeinek bemutatásának rendeltük alá. Visszaköszönnek már korábbi fejezetekbôl ismert példák, de bemutatunk olyan lehetôségeket is, melyek számítógép felhasználása nélkül csak komolyabb, középiskolai keretek közé nem illeszkedő eszközök bevonásával tárgyalhatók. A példák tárgyalása során mindenütt kitérünk a felhasznált eszközök előnyeinek didaktizálására.

\subsubsection{Nevezetes összegek - egy példa ismét}

A 3.1.3. fejezet problémáját tárgyaljuk ismét, ezúttal számítógéppel segítve a felfedezést.

Önállóan szeretnénk hát megtalálni, felfedezni az $1+2+3+\ldots+n$ összeg zárt alakját.

Számoljuk ki a fenti összeget az elsô néhány $n$-re!

$$
\begin{aligned}
1 & =1 \\
1+2 & =3 \\
1+2+3 & =6 \\
1+2+3+4 & =10 \\
1+2+3+4+5 & =15
\end{aligned}
$$

A kérdés, mellyel a felfedezések ösztönözhetôk, természetesen merül fel magukban a diákokban is: Milyen, sem a bal oldali előállítást, sem az előzố tagokat nem használó összefüggés van a jobb oldalon található tagok között? Itt lép színre a tanár katalizátor szerepben: Használjuk a http://oeis.org/ oldalt! Az itt található The On-Line Encyclopedia of Integer Sequences (OEIS) egy online elérhetôségü sorozat gyújtemény. A felkínált mezôbe beírva a vizsgált sorozat (elsô) néhány tagját, a Keresés gomb lenyomásával megkapjuk az adott kezdőtagokra leginkább illeszkedó, legjellemzőbb sorozatokat. Minél több tagot írunk be, annál inkább releváns találatokat kapunk [124].

Jelen esetben az elsố találat a következô:

Triangular numbers: $\quad a(n)=C(n+1,2)=n(n+1) / 2=0+1+2+\ldots+n$.

Innen pedig már folytathatjuk a felfedezéseket a sejtés megerôsítésével a korábban ismertetett módon. 
3.13. Megjegyzés. Felmerülhet a szkeptikusokban a kérdés, miért használtunk számítógépet, ha a probléma, ráadásul felfedeztetéssel, e nélkül is tárgyalható volt. A számítógép ezen egyszerú használatának is számos elônye van. A legtöbb tanár küzd az idô szorításával; a felfedezés számítógéppel gyorsabb, s mégis a tanulók aktív cselekvésével valósul meg. ${ }^{4}$ Ne feledjük, hogy diákjaink már digitális bennszülöttek. Megszokták, hogy az iskolán kívül gyakorlatilag mindenütt, minden információ változatos, digitális formában jut el hozzájuk. Sokkal természetesebben nyúlnak egy egyszerú parancs hatására „csodákat” produkáló weblaphoz, mint kavicsokhoz, vagy tollhoz és négyzetrácsos papírhoz. További előnye még, hogy a kísérletek gyorsan, és szinte korlátlan számban megismételhetôk. A kísérletek nem csak, hogy megismételhetók, de igény szerint módosíthatók is, s ezáltal új felfedezések tehetôk; könnyen zárt alakot találhatunk az elsố $n$ négyzetszám vagy akár köbszám összegére. A számítógép segítségével korábban elérhetetlen problémák válnak hát megközelíthetôvé, s ez használatuk másik nagy előnye.

\subsubsection{Halmazmüveletek tulajdonságai, halmazelméleti azonos- ságok}

A halmazelmélet alapjainak az általános iskola 8., illetve a középiskola 9. osztályában történố tanításához kiválóan használható a következô, Palincsár Zoltán által alkotott program. (A program hozzáférhető (volt) a jelenleg nem üzemelő Sulinet oldalakon. A szerző mindössze 16 évesen készítette egy pályázatra.)

A programban lehetôségünk van halmazmúveletek megadására, (egy, két, illetve három halmazra vonatkozóan) melyeknek megfeleltetett tartományt a program a megfelelő ablak Venn-diagramján szemlélteti. A kétablakos rendszernek köszönhetôen lehetôségünk nyílik halmazmúveleti azonosságok szemléltetésére, felfedeztetésére.

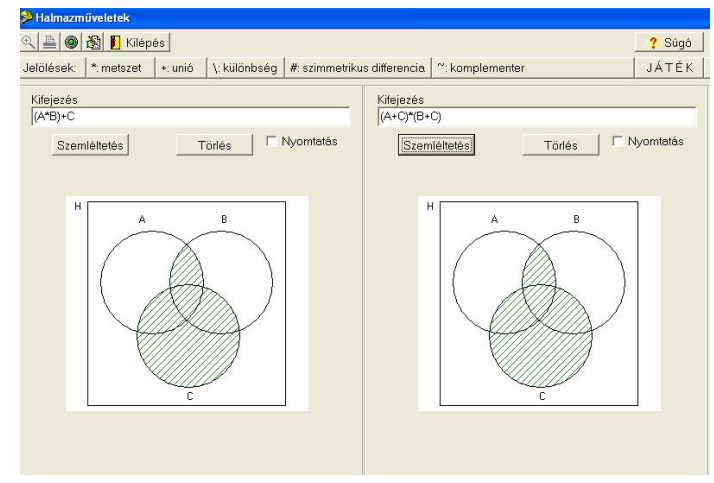

3.12. ábra. $(A \cap B) \cup C=(A \cup C) \cap(B \cup C)$

\footnotetext{
${ }^{4} \mathrm{~A}$ tananyag elvégzése érdekében diktált gyorsabb tempó egyik következménye általában sajnos az, hogy a diák külsố szemlélôvé válik az órán.
} 
A program szolgáltatásai között játék is szerepel, melyben egy adott halmazmúveletsorhoz tartozó tartományt kell a Venn-diagramon színezni; illetve egy adott, a Venn-diagramon megjelölt tartományhoz tartozó lehetséges halmazmúveletsort kell megadni.

3.14. Megjegyzés. A fentiekben példát láthattunk arra, hogy hogyan válik lehetségessé játékos formában a felfedeztetés egy egyszerú alkalmazás segítségével. A program használata nem igényel semmiféle elôkészületet (még telepíteni sem kell) vagy elôképzettséget. A táblára felkerülő, statikus, korlátozott számú ábra helyett a tanulók aktív részvételével megalkotott, korlátlan számú, dinamikus változtatható ábrasereg segíti, sôt lehetôvé teszi a halmazmúveletek és ezek tulajdonságainak empirikus megismerését, belátását, melynél többet jelen témakörben aligha tûzhetünk ki célul. A programot a gyerekek haza is vihetik, illetve otthoni géprôl is elérhetô. Így a kísérletek megismételhetôk, az otthoni gyakorlás is lehetséges.

\subsubsection{A háromszög belsô szögeinek összege IV.}

A 3.1.7. fejezet ábráit adó animációt használjuk. Az animáció megtalálható a Wolfram Demonstrations Project oldalain [169]. A Mathematica környezetben készült program használatához külön szoftver nem szükséges. Az animáció használatával elvész ugyan a kézzel készült, s „behajtogatott” háromszögnél létrejött személyes tapasztalás, viszont a gépi használat itt is gyorsabb, otthon szintén rekonstruálható, sôt ugyanott hasonló bizonyítások tömkelege található, így lehetôség van az önálló kutatásra ezen a szinten is. Az animációban a paraméterek változtatásával (pl. a csúcsok mozgatásával) lehetôségünk van mérések, kísérletek százainak elvégzésére.

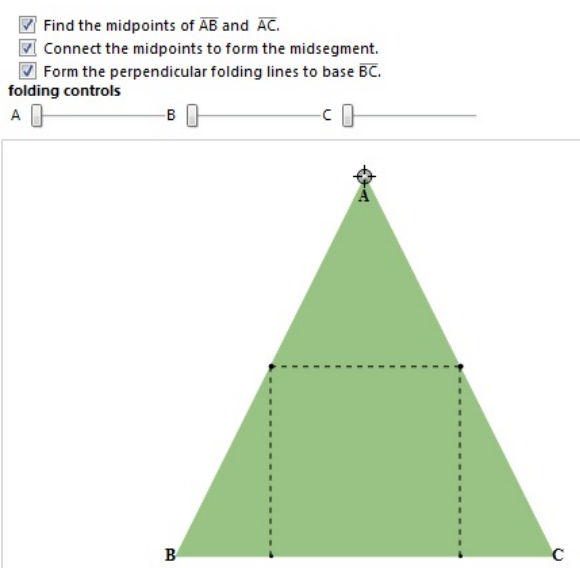

(a)

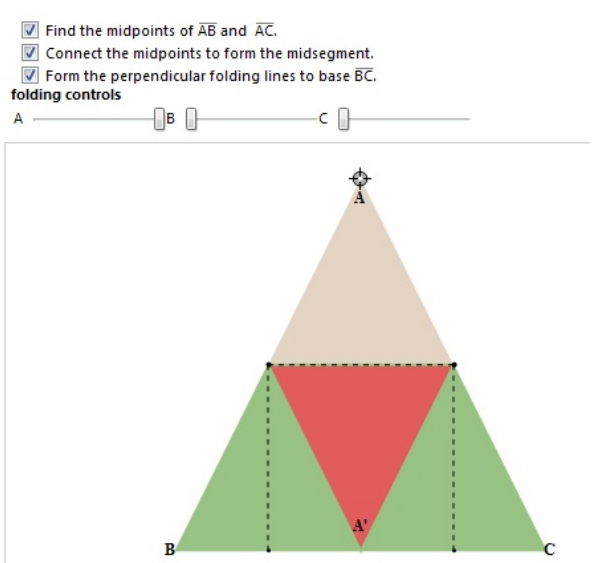

(b) 


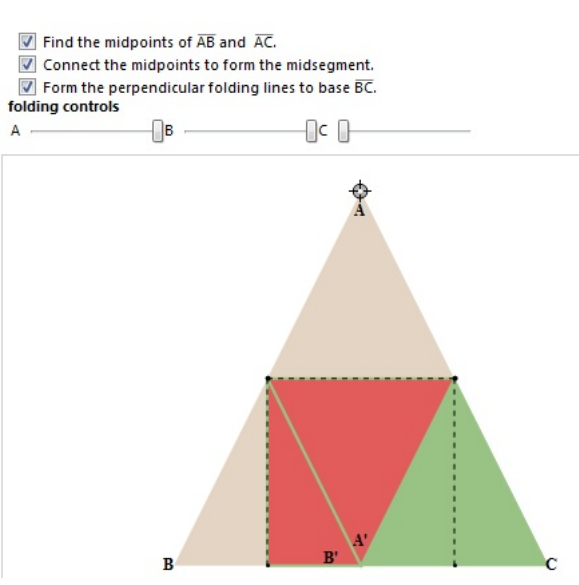

(c)

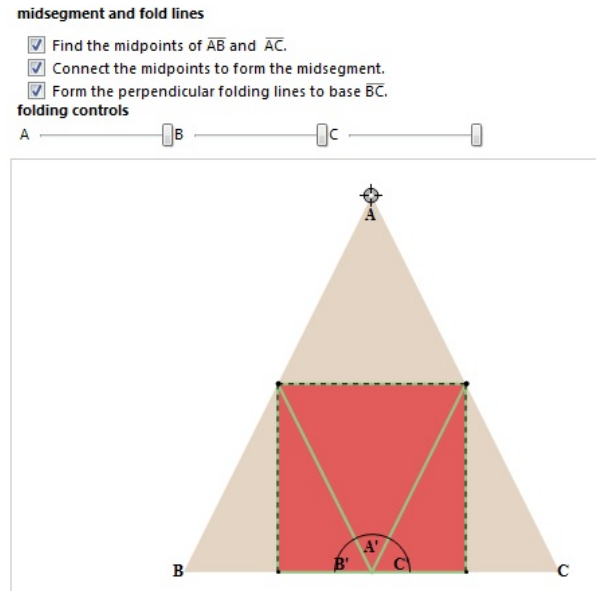

(d)

3.13. ábra. Bizonyítás(?) - A háromszög belsổ szögeinek összege IV.

A következôkben két nehezebb problémával foglalkozunk. Átlagos középiskolai eszközökkel nem tárgyalhatók, s ami jelen szempontból kiemelten fontos: számítógépek segítsége nélkül érdemben csak nagyon nehezen megközelíthetők.

\subsubsection{A Monty Hall-dilemma - a számítógép és az intuíció}

A már-már klasszikus probléma eredetét illetően megoszlanak a történeti források. Paul Hoffman szerint ([75]) elôször a Let's Make a Deal címú amerikai televíziós játék utolsó feladataként tûnt fel; nevét is innen, a játék mûsorvezetôjéról kapta ${ }^{5}$. Valójában először Steve Selin tollából tünt fel az American Statistician hasábjain 1975-ben. Szakmai körökben híressé (hírhedtté) azonban a Parade magazin 1990. szeptember 9-i számának Marilyn vos Savant vezette Ask Marilyn rovata tette. Azóta számos változata, sôt egész folklórja alakult ki [142]. A probléma a következô.

3.15. Feladat. Képzeljük el, hogy egy televíziós vetélkedőn veszünk részt, ahol három ajtó közül kell választanunk. Az egyik mögött autó van, a másik kettố mögött szamár. Kiválasztjuk az egyik ajtót, mire a músorvezetô, aki természetesen tudja, melyik mögött van az autó, kinyit egy másik ajtót, amelyik mögött szamár van. (Ilyen ajtót mindig tud nyitni.) Ezután választanunk kell; vagy ragaszkodunk eredeti döntésünkhöz, vagy meggondoljuk magunkat, és a harmadik, ki nem nyitott ajtót választjuk. Melyik a jobb döntés?

\footnotetext{
${ }^{5}$ A játékot gyakorlatilag változatlan formában Magyarországon is bemutatták, a Zsákbamacska címú televíziós vetélkedôben.
} 


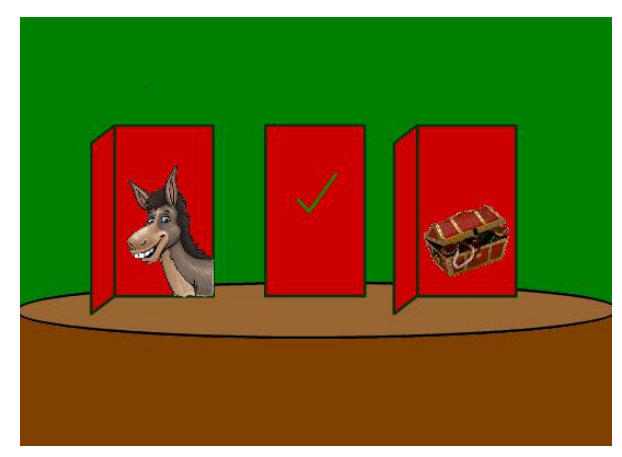

3.14. ábra. A Monty Hall-dilemma

A probléma ismertetése után érdemes megkérnünk a diákokat arra, hogy tippeljék meg a nyerés valószínúségét a két stratégia (a játékos kitart eredeti döntése mellett, illetve ajtót vált) esetén. A kérdés jó eséllyel meg fogja osztani óket, hiszen a korabeli matematikusokkal is ezt tette. Nem akarták elfogadni ugyanis, hogy ebben a helyzetben érdemes élni a músorvezető által felkínált lehetôséggel, és ajtót kell váltani. Olyannyira, hogy amikor Vázsonyi Endre ismertette a problémát Erdôs Pállal, maga Erdős sem látta értelmét váltani. Meggyôzni ôt is csak a Stanislaw Ulam által kidolgozott Monte Carlo-módszer segítségével lehetett. A módszer lényege, hogy egy adott esemény valószínúségének numerikus kiszámítása helyett számítógépek segítségével (elegendően) sokszor szimulálják a kísérletet. Egy ilyen kísérletsorozat eredményét mutatja az alábbi ábra.

\begin{tabular}{|c|l|l|}
\hline A játékos nem vált ajtót & Nyerő kísérletek száma: 3340 & Összes kísérletek száma: 10000 \\
\hline A játékos ajtót vált & Nyeró kísérletek száma: 6660 & Összes kísérletek száma: 10000 \\
\hline
\end{tabular}

3.15. ábra. A Monty Hall-dilemma és a Monte Carlo-módszer

3.16. Megjegyzés. Ebból is látszik, hogy értô kezekben a számítógép már gyakorlatilag létrejötte pillanatától fogva szerepet játszik a matematikai felfedezésekben, tudományos szinten is.

A kapott relatív gyakoriságok sokat segíthetnek az esemény valószínúségének meghatározásában. Továbbá meg is szüntethetik azt a bizonytalanságot, amibe az emberek akkor kerülnek, amikor az intuíció és a valóság között ilyen nagy a különbség. A fenti, illetve a fentihez hasonló kísérletsorozatok segítségével szemléltethetô a nagy számok törvénye is.

3.17. Megjegyzés. Továbbra is kérdés, hogy (iskolai szinten) elfogadhatjuk-e ezt az intuitív belátást bizonyításnak? A diákok a kettô között sokszor egyáltalán nem éreznek különbséget, sôt az előbbit erôsebbnek érzik, hiszen azt megtapasztalják, míg a (deduktív) bizonyítást nem. Jelen esetben persze kicsit többrôl van szó, mint puszta intuícióról. 
Marilyn vos Savant is számos módon próbálta meggyőzni az emelkedett hangnemben ellenkezô matematikusokat:

(1) Képzeljük el, hogy a játékban egymillió ajtó van. A játékos választ egyet, majd a mûsorvezetô, aki pontosan tudja, hol van az autó, egyetlen másik ajtó kivételével kinyitja az összeset. Most hogyan döntenénk?

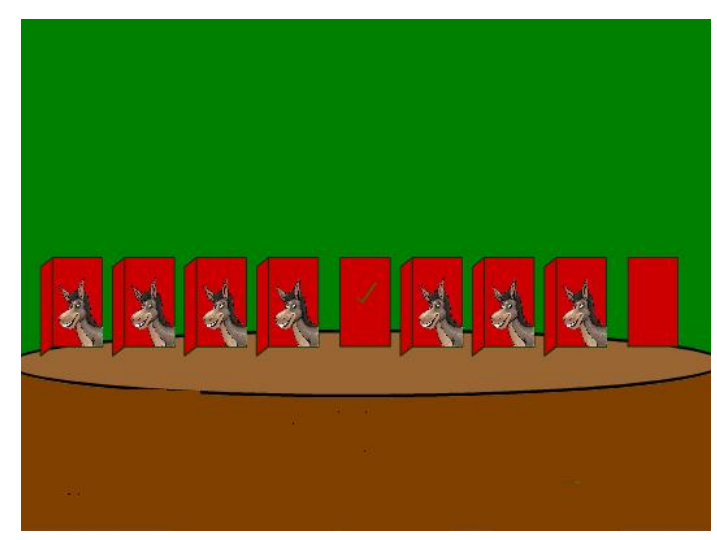

3.16. ábra. Dilemma: Hogyan döntenénk?

(2) Képzeljük el, hogy miután a músorvezetô kinyitotta az egyik ajtót, leszáll a színpadra egy ufó, s egy kis zöld ember bújik ki belőle, s neki is dönteni kell. Ố valóban $50 \%$ eséllyel dönt jól, hiszen neki nincs meg az az előnye, ami megvan a játékosnak, nevezetesen a músorvezetô segítsége.

3.18. Megjegyzés. Egy másik lehetséges indoklás az, hogy az a jobb, ha nem tartunk ki eredeti elképzelésünk mellett, mert ekkor akkora eséllyel nyerünk, mint amekkora eséllyel eredetileg rosszul választottunk, vagyis $2 / 3$ valószínúséggel. Ennek a gondolatmenetnek az is az elônye, hogy pusztán a szimmetriára épül, s nem használja, még hallgatólagosan sem, a feltételes valószínúség fogalmát.

Magát Erdôs Pált sem sikerült számítógépek segítsége nélkül meggyôzni. Hogyan várhatnánk el ezt akkor a diákjainktól?

\subsubsection{A lusta pénztáros - a számítógép és a sejtés}

A probléma a következő.

3.19. Feladat. Egy mozi pénztára előtt emberek állnak sorban. A jegyek egységesen 500 forintba kerülnek. A sorban állóknak egymástól függetlenül $\frac{1}{2}-\frac{1}{2}$ valószínüséggel vagy 500 forintosa, vagy 1000 forintosa van. A lusta pénztáros nem gondoskodott nyitás előtt váltópénzrôl. Várhatóan hány mozilátogatót tud majd kiszolgálni a pénztáros? 
Itt is egy számítógépes animáció segítségével közelítjük meg a problémát, s ezáltal az tárgyalhatóvá válik a valószínúségi változó fogalmával éppen csak ismerkedô, vagy azzal nem is rendelkezô diákok számára is.

A módszer a következô. Egy az interneten elérhetô (vagy akár magunk által is elkészíthetô) animáció (program) segítségével végezzünk kísérleteket. Figyeljük meg, hogy néhány (számos) sorban állást szimulálva hogyan alakul a kiszolgált vásárlók száma. Érdemes tippelôs játékot játszani; a játékosok (diákok) megtippelik, hogy hány vásárló fog jegyhez jutni, és akinek a tippje legközelebb lesz az eredményhez, az nyer. A következô ábrák egy, a Sulinetról származó animációból származnak, de hasonlót találhatunk például számos egyetem [118], vagy a Wolfram [169] oldalán is.

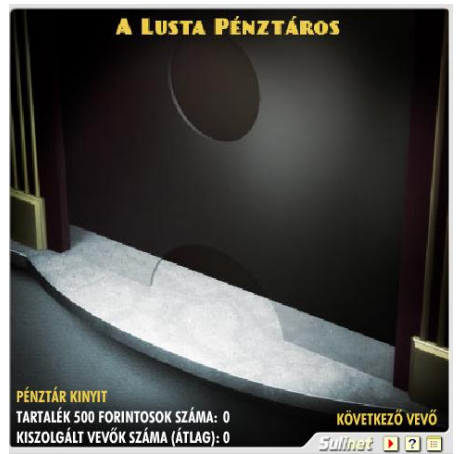

(a)

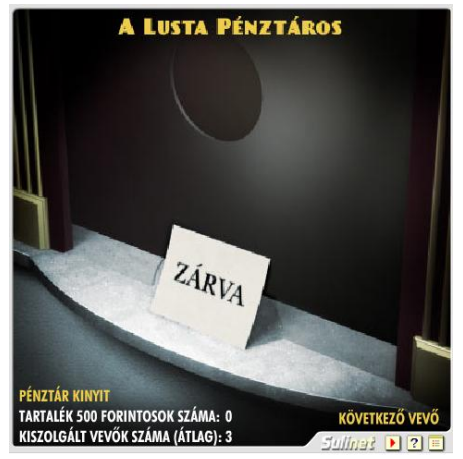

(c)

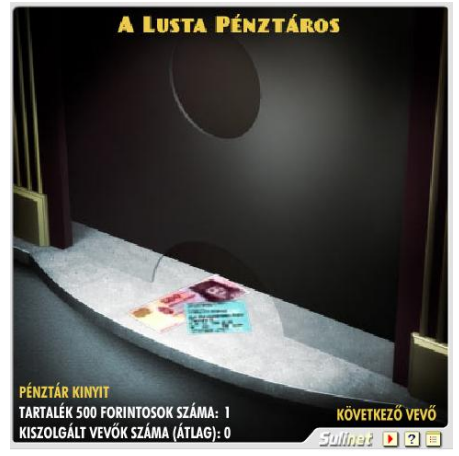

(b)

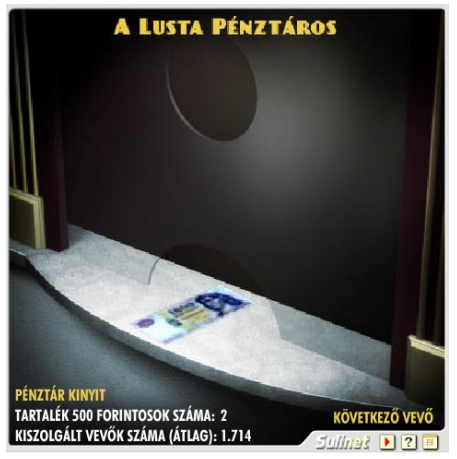

(d)

3.17. ábra. A lusta pénztáros

Ezzel eljuthatunk a matematikai alkotás egyik legfontosabb - s jelen szinten elérhetô egyetlen - eleméhez, a sejtéshez. Mégpedig ahhoz a (helyes) sejtéshez, hogy jelen valószínúségi változónak nincs várható értéke. A lusta pénztáros problémája tehát arra is példát mutat, hogy a számítógépek felhasználásával nem csak szemléltethetünk, vagy a bizonyítást segíthetjük, de esetenként magának a sejtésnek a kialakítása sem képzelhetô el nélkülük.

3.20. Megjegyzés. A valószínúségi változó várható értékét leíró sor divergenciájának bizonyításához szükséges eszköz pl. a Stirling-formula és a majoráns kritérium [42]. 


\subsubsection{Módszertani összefoglaló}

A fejezetben igyekeztünk megmutatni, hogyan is tud a „kiváló”, vagy a „, nagyszerú” tanár számítógépes demonstrációk segítségével inspirálni. Példát láthattunk arra, hogy a számítógép hogyan segít felfedezések katalizálásában (3.3.2.). A számítógép segítségével lehetôségünk van a paraméterek változtatásával újabb és újabb felfedezések ösztönzésére. Egyszerú alkalmazások (3.3.3., 3.3.4.) felhasználásával példát láttunk egyrészt a vizuális reprezentációk ösztönzô erejére, másrészt a tömeges kísérletek jótékony hatására, a „deus ex machina” elkerülésére. Megmutattuk, hogy a számítógépes reprezentációk használata elkerülhetetlen lehet bizonyos problémák (3.3.5., 3.3.6.) tárgyalása kapcsán.

\subsection{Felfedezések a számítógép alkotó jellegü felhasz- nálásával}

-Ön szerint mikor érik el számitógépek az elsố Nobel-dijas felfedezést?

-Szerintem már régen elérték [144]. (HERBERT Simon ${ }^{6}$ )

\subsubsection{Bevezetés}

Az előzô fejezetben javarészt az interneten bárki által szabadon elérhetô és felhasználható konzerveket mutattunk be. Ezek használata számos, a fentiekben részletesen kifejtett elônyökkel jár, ám nem minden esetben elegendô. A technikai fejlődés, a digitális bennszülöttek folyamatosan megújuló világa, folyamatosan fejlődő eszközöket kíván. Szükség van tehát rá, hogy mi magunk is hozzunk létre alkalmazásokat, hiszen ezek továbbfejlesztése a legkézenfekvóbb, legegyszerúbb lehetôség. Emellett szükség van arra is, hogy diákjainkat is ösztönözzük saját alkalmazások létrehozására. A továbbiakban főként ezek szolgálnak majd felfedezéseink alapjául.

Először röviden bemutatjuk az alkotó jellegû használatot lehetôvé tévô rendszereket általánosságban, majd részletesen néhány, az oktatásban jól, s a továbbiakban általunk is használt szoftvert.

\subsubsection{Komputer-algebrai rendszerek (CAS)}

A számítógépek tudományos, illetve oktatási célú használatában mérföldkőnek számított az elsô, szimbolikus számítások elvégzésére is alkalmas rendszer. Ez a MIT-n kifejlesztett MACSYMA volt. Ez volt az elsô rendszer, amely alkalmas volt algebrai manipulációkra. Sôt, ennél jóval többre. A segítségével lehetôség volt egyenletrendszerek,

\footnotetext{
${ }^{6}$ Herbert Simon Nobel- (1978) és Turing-díjas (1975) közgazdász
} 
differenciálegyenletek megoldására, integrálok meghatározására, mátrixok invertálására, sajátértékek kiszámítására, s általában szimbólumokat tartalmazó kifejezésekkel való numerikus számításra. A ma használt legelterjedtebb komputer-algebrai rendszerek a Mathematica, Maple, MatLab, Maxima. A legtöbb ilyen rendszer drága, sokszor még az egyetemi licenszek beszerzése is gondot okoz, így ezek az állandó forráshiánnyal küzdô (közép)iskolák számára elérhetetlenek. Kivételt csak a Maxima képez, ez ugyanis nyílt forráskódú, ingyenes rendszer. A rendszerek legtöbbjéról általánosságban elmondható, hogy szintakszisuk, beleértve az összetett matematikai objektumok bevitelét is, formális, logikus. (Mindez például a késóbbiekben bemutatandó WebMathematics Interactive (WMI) esetében teljesen intuitív.) Kiválóan használhatók az egyetemi oktatásban is, néhány órás gyakorlás után lehetôségünk van tulajdonképpen egy egyszerú programozási nyelv elsajátítására. Kevés ismerettel is viszonylag bonyolult dolgok állíthatók elô. A rendszerek használatával lehetôségünk van pl. egy $15 \times 15$-ös mátrix inverzének, sajátértékeinek gyors kiszámítására (akár szimbolikusan is!), vagy egy több egyenletból álló, többismeretlenes differenciálegyenlet-rendszer megoldására; tehát olyan számításokra, melyeket kézi erôvel nem, vagy csak indokolatlanul nagy energia- és időbefektetés árán tudnánk megvalósítani. Könnyedén kirajzoltathatjuk egy-, illetve kétváltozós függvények grafikonjait, készíthetünk továbbá valós idejû animációkat, melyekkel a kísérletezési lehetôségek tárháza tárul elénk. Olyan dolgokat tehetünk láthatóvá, olyan számításokat végezhetünk el, melyekről korábban még csak nem is álmodhattunk.

\subsubsection{Szoftverek az oktatás szolgálatában}

Az alábbiakban a teljesség igénye nélkül bemutatunk néhány, az oktatásban kiválóan használható, többségében az interaktív táblákkal is együttmúködni képes népszerú szoftvert.

\section{GeoGebra}

A programot (www.geogebra.org) Markus Hohenwarter kezdte el fejleszteni a Salzburgi Egyetemen. Az elsô verzió 2002 januárjában jelent meg angol és német nyelven. A szerzô múvét ingyenesen elérhetôvé tette az interneten. Hamarosan annyi kérdést és ötletet, fejlesztési javaslatot kapott, hogy a program folyamatos fejlesztésére egész munkacsoport jött létre. Azóta a világ szinte valamennyi kontinensén számos GeoGebra Intézet jött, s jön folyamatosan létre [59]. Az egyik éppen Szegeden, a Bolyai Intézet berkein belül szervezôdik. A fejlesztések folyamatosan lépést tartanak a kor igényével, így például nem csak javascript alapú, a feladatokat dinamikus újrageneráló s így akár számonkérésre, illetve annak gyors kiértékelésére is alkalmas feladatbankok, de okostelefonra optimalizált verzió is készülőben van.

A GeoGebra legfóbb érdeme, hogy két- (manapság már három-) ablakos rendszerének köszönhetően egyesíti a komputer-algebrai rendszerek (CAS) és a dinamikus 
geometriai szoftverek (DGS) elönyeit; a program neve is erre utal, GeoGebra, azaz geometria + algebra. Az oktatásban pedig azért terjedhetett el ilyen gyorsan és sikeresen, mert ingyenes, platformfüggetlen, sốt még csak letölteni sem kell. (Ezzel megkímélvén a tanárt attól, hogy az óráit csak hathatós rendszergazdai segítséggel tudja megtartani.) Egyszerú felépítése és könnyû kezelhetôsége ellenére az iskolai tananyag szinte valamennyi területe jól tanítható általa, kezdve az egész számok aritmetikájától, a függvény- illetve geometriai transzformációkon keresztül, a statisztikai alkalmazásokon át, egészen az analízis fogalmainak (derivált, integrál, Taylor-polinom, ...) szemléltetéséig. A program kiválóan alkalmas a különböző absztraktsági szinten lévô fogalmak szemléltetésére, a dinamikusan változtatható paramétereknek köszönhetően pedig a felfedeztetésre. Nem utolsó sorban egy lelkes, aktív és nyílt közösségnek köszönhetően - melyhez bárki csatlakozhat - folyamatosan bővül az interneten elérhető kész segédanyagok rendszere, így a szoftverrel tartott órára való felkészülés a kezdeti időben sem vesz több idôt igénybe, mint a hagyományos, frontális, tábla-krétás óra megtervezése.

\section{Autograph}

A program jelenlegi verzióját Mark Hatsell írta, elsôsorban a brit Oundle School matematika óráin szerzett tapasztalatok alapján. Az ô nevéhez füződik az Autograph játékipari technológiákból adaptált ötlettel megalkotott 3D-s modulja [5]. A program a legtöbb, felsô tagozaton, illetve középiskolában előkerülő terület oktatására alkalmas. Tökéletesen múködik együtt a digitális táblákkal, egy egyszerú kiegészítô eszköz segítségével távolról is irányítható, így a tanár nincs a táblához láncolva, sốt a diákok is tudják távolról kontrollálni a táblán történteket. A program elsôsorban Angliában népszerú $[12,13]$, de az évente megrendezett nemzetközi továbbképzés és konferencia hatására a felhasználótábora folyamatosan bôvül. A program egy határozott - a többitôl megkülönböztetô - elônye, hogy alkalmas a grafikonok lassú megjelenítésére. Ez azt jelenti, hogy az (ismeretlen) függvény grafikonja paraméterezhetően folyamatosan rajzolódik ki a képernyôre. Bármikor megállíthatjuk a kirajzolást, kérdéseket tehetünk fel a függvény hozzárendelési szabályára, további menetére, tulajdonságaira vonatkozóan.

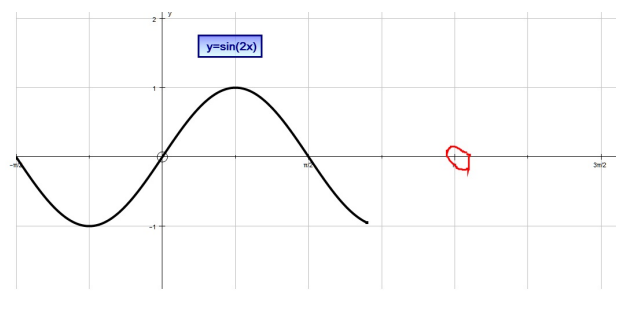

(a)

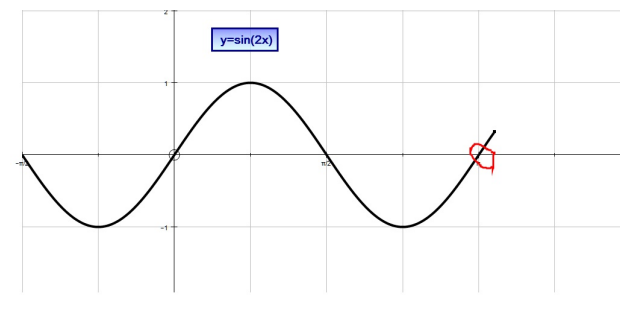

(b)

3.18. ábra. Autograph - Lassú ábrázolás: $\sin 2 x$ hol a következô zérushely? 


\section{Derive}

A Derive 1988-ban jött létre. Elődje a muMath, az elsố oktatásra adaptált szoftverek egyike volt, elsố verziója 1979-re datálható. A Derive fejlesztése sajnos leállt, a disztribútorok az utolsó példányoktól is már csak árukapcsolás útján tudnak megválni. A programot a világ számos országában, s több mint 50 magyar oktatási intézményben is használják, illetve használták. Numerikus és szimbolikus számítások elvégzésére, kétés háromdimenziós ábrázolásokra, vektor- és mátrixmúveletek elvégzésére egyaránt alkalmas. Módszertani szempontból egyik legnagyobb elônye a lépésenként is elôhívható feladatmegoldás volt. (A feladat vonatkozhat egyenlet megoldására, mátrix invertálására, integrál meghatározására, s számos egyéb múvelet elvégzésére.)

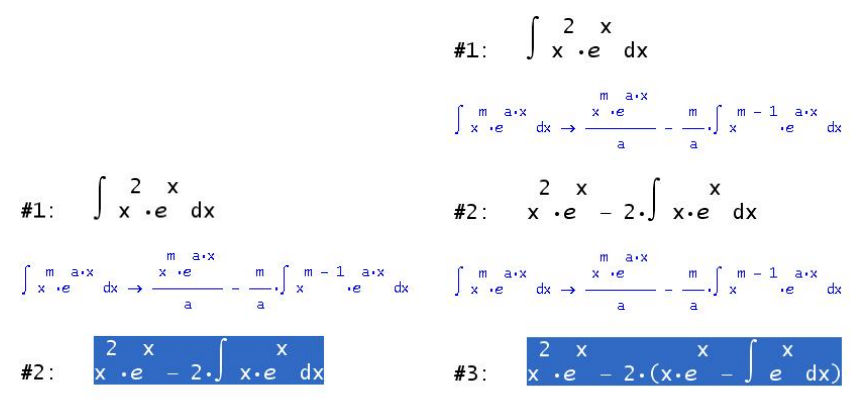

(a)

(b)

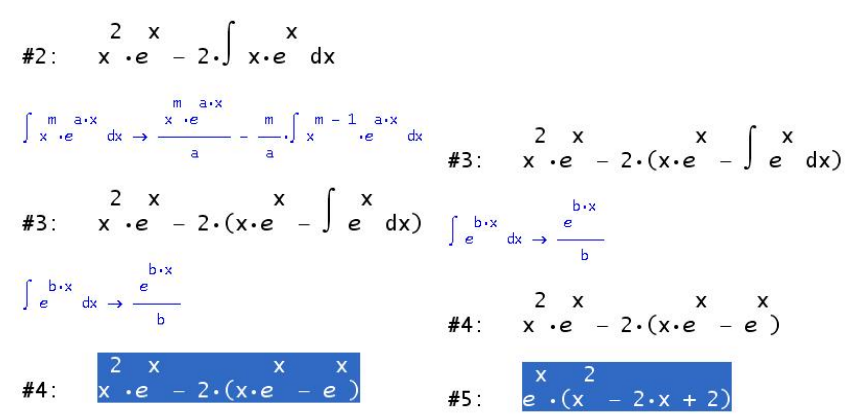

(c)

(d)

3.19. ábra. Derive - Integrálás lépésenként - $\int x^{2} \cdot e^{x} d x$

\section{WMI}

A WebMathematics Interactive (WMI) egy internetes on-line tanulói környezet, mintegy 20 szabadon felhasználható forráskódú szoftver ötvözése. Az egymással kommunikáló programok új struktúrába való szervezésével és egy rendszerbe történô integrálásával, egy olyan keretfeltételeket biztosító program jött létre, amely új didaktikai szempontokat támogató interaktív matematikai modulok számítógépes megvalósítását teszi lehetôvé. 

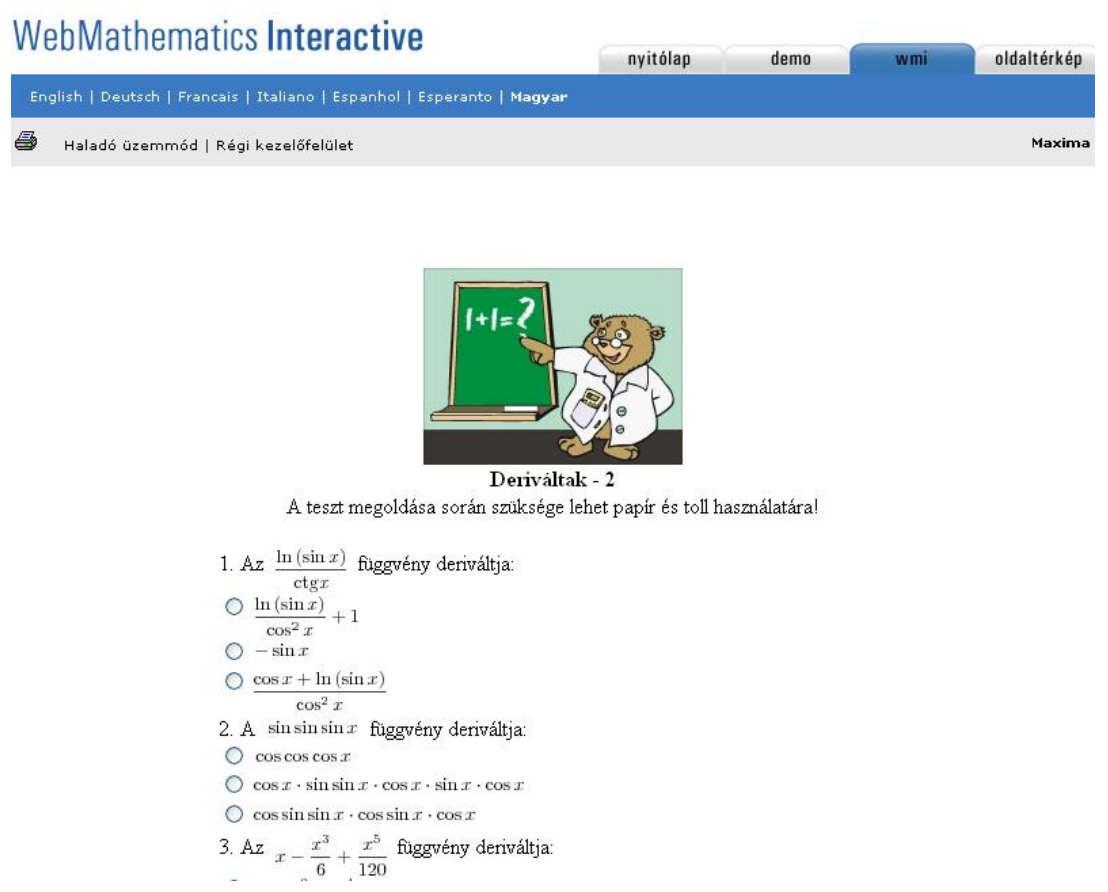

3.20. ábra. WMI - Pillanatkép

A WMI egy olyan környezetet teremt, amely a mesterséges intelligenciát és a matematikadidaktika szakmai tapasztalatát kihasználva módszertani szempontból is értékes (nemcsak végeredményt szolgáltató) matematikai modulok konstruálását biztosítja a matematika oktatói számára. Így a komputer-algebrai rendszerek ereje anélkül kerül kiaknázásra, hogy a felhasználói oldalon lévô diáknak bármit is tudnia kellene ezek múködésérôl. Elsôsorban egyetemi, illetve fôiskolai használatra készült, de tekintve a tananyagok átfedését, illetve a matematika spirális felépítését, a középiskolában is kiválóan használható [86, 87]. Megalkotója egy szegedi csapat, az ötletgazda pedig Kovács Zoltán. Az elképzelés jelenleg matek.hu néven fut [166]. Egy tematikus, jól átlátható, könnyen kezelhető internetes felületen adhatjuk le „igényünket”, ami lehet egy egyenlet megoldása, egy integrál meghatározása, egy egy- esetleg kétváltozós függvény ábrázolása, vagy egy határérték meghatározása. A válasz azonnal előáll, így kiválóan alkalmas önálló tanulásra, gyakorlásra, saját munkánk ellenőrzésére is. A felkészültség mértékének ellenőrzésére dinamikus és statikus tesztek is rendelkezésünkre állnak. A tanulói illetve tanári tudásellenőrzés tehát több oldalról is támogatott. A WMI alapszolgáltatásai mellett tematikus modulokat tartalmaz a lineáris algebra, analízis, diszkrét matematika, analitikus geometria témakörökben, megkönnyítvén ezen területek feldolgozását. A WMI tökéletesen alkalmas az e-learning alapú oktatásra is. Mi sem példázza ezt jobban, mint hogy a SARS járvány idején Chu-Ching Huang, a Chang Gung University tanára a WMI-vel helyettesítette az elmaradt kontaktórákat [87]. 


\section{További lehetôségek}

Ebben a részben bemutatunk néhány, a szerzô által is használt, többségében ingyenes, vagy jól használható ingyenes próbaverzióval rendelkező szoftvert.

(a) Euler 3D - A program szegedi, Petró Tamás készítette, az ötlet atyja, és a kidolgozás irányítója pedig Szilassi Lajos volt. A program sokáig ingyenesen hozzáférhetô volt, mígnem a Mozaik Kiadó Kft. megvásárolta [44].

(b) Euklidesz - Geometriai szerkesztôprogram, mely 1998-ban jelent meg. A Mozaik Kiadó Kft. megvásárolta, illetve a GeoGebra kiszorította a piacról [43].

(c) Cabri - A szoftvercsaládnak számos tagja van, melyek elsôsorban Franciaországban és az angolszász területeken terjedtek el. Kapcsolódó szakirodalom szerencsére már magyar nyelven is elérhetô $[27,114,152]$.

(d) The Geometer's Sketchpad [60, 1, 68, 46]

(e) GrafEq [64]

(f) Poly [134]

(g) Graph [65]

A következôkben öt példát mutatunk be, a számítógép alkotó jellegú felhasználását prezentálandó.

\subsubsection{A Thalész-tétel}

A kézzel szerkesztett ábra, a saját kezú mérés meggyôzô erejét nem pótolhatja semmi (3.1.8. fejezet). A bizonyosság erôsebb fokának kialakításában (a bizonyításban?) viszont haszonnal alkalmazhatjuk a számítógépet.

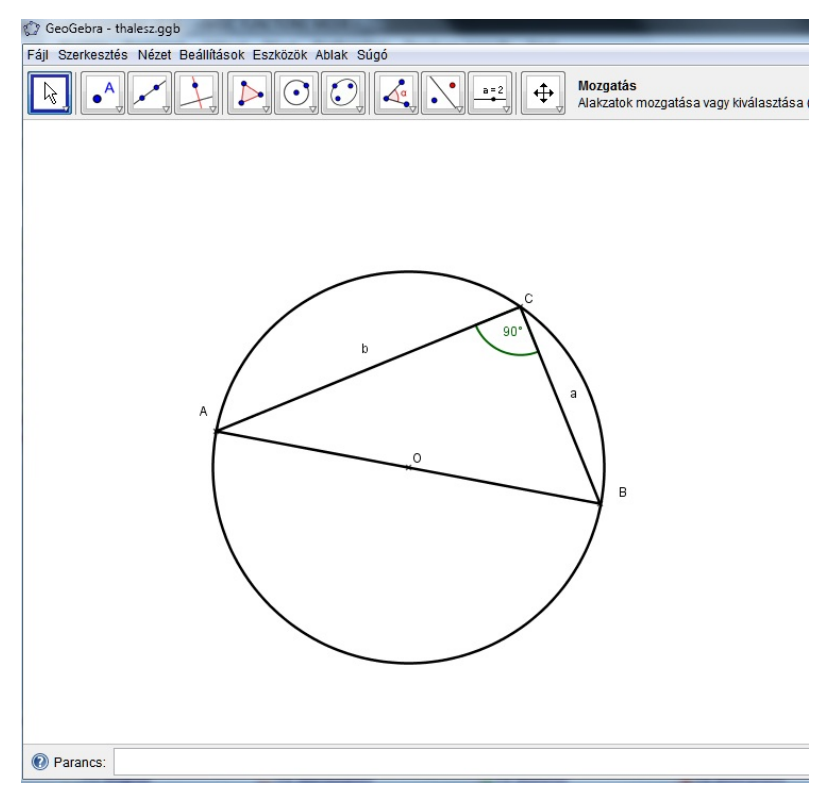

3.21. ábra. Thalész-tétel - Pillanatkép 
Az alábbi, GeoGebrában készített alkalmazás elkészítése gyakorlatlan felhasználók számára sem vesz igénybe annyi idôt, mint egyetlen statikus ábra megszerkesztése. Számtalan elônye közül kiemelendô, hogy mozgatható a kör, az átmérô, a kerületi pont, sốt ez utóbbi akár animálható is folytonosan a körön. Az animáció valójában nem folytonos, de kijelenthető, hogy minden gyakorlati igényt kielégítôen folytonosnak tekinthetô. A körvonalon mozgó pont természetesen diszkrét pontok sokaságán „ugrál”, de segítségével annyi kísérlet és mérés végezhetô el egyszerre, amennyit számítógépes segítség nélkül nem lennénk képesek végrehajtani.

3.21. Megjegyzés. A püthagóreusok a geometriát hisztoriénak tartották, azaz kimondottan tapasztalati tudomány volt. (A számelmélet neve mathéma volt.) Ugyanakkor maga Thalész volt az a mérföldkô a matematikában, aki a szemléletre alapozott tapasztalati geometriát elválasztotta az érzékekre már nem támaszkodó, (logikai) bizonyítást igénylô geometriától.

\subsubsection{Trigonometrikus azonosságok}

A trigonometrikus azonosságok két fő tulajdonsága, diákszemmel nézve, hogy sokan vannak és hasonlítanak egymásra. Tanári szempontból persze jelentôségüket a függvénytranszformációk, trigonometrikus egyenletek, illetve trigonometriai számítások terén betöltött szerepük adja. Megkedveltetni óket szinte lehetetlen, viszont legalább néhányat diákjaink emlékezetébe tudunk vésni, ha azokat ook maguk fedezik fel. Erre mutat példát a következô, Autographban kivitelezett kísérlet.

Az ábrán a $\cos x$ függvény grafikonja látható, és egy pont, amelyet animálunk egy függvény grafikonja mentén. A pont láthatóan az $\cos x$ függvény $x$ tengelyre vett tükörképe mentén halad, tehát a rejtett görbe meggyôzôen sok helyen vett értéke alapján tapasztaltak szerint az $y=-\cos x$ függvény grafikonja.

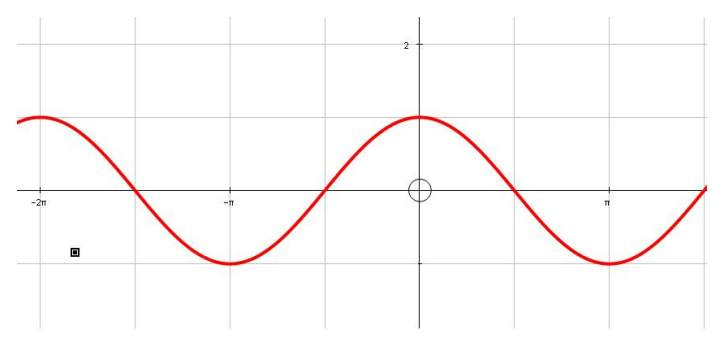

3.22. ábra. Hol halad a pont...? 
Az $y=-\cos x$ függvény grafikonját kirajzolva, a pontot tovább animálva, empirikus úton szerzett meggyőződésünk megdönthetetlenné válik.

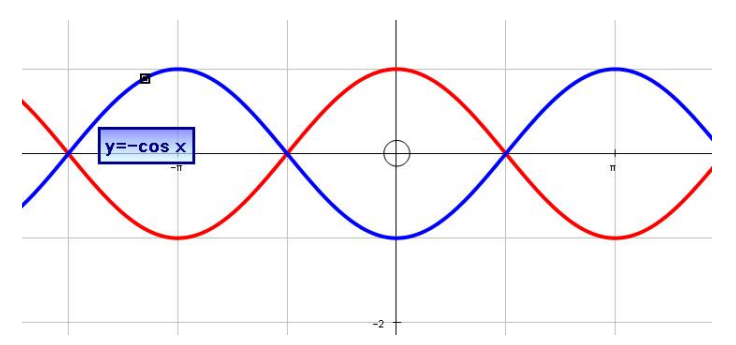

3.23. ábra. ... az $y=-\cos x$ görbe mentén

Ekkor, például egy szövegdoboz segítségével, kiírathatjuk a mozgó pont valódi koordinátáit (megjeleníthetjük az eddig rejtett függvénygörbe hozzárendelési szabályát), s így láthatóvá válik, hogy a pont által leírt görbe az $y=\cos (x-\pi)$. A döbbenet (felfedezés) ereje ebben a szituációban óriási lehet, olyannyira, hogy akár a miért megválaszolása érdekében is lépéseket kell tennünk, a diákok nyomásának engedve.

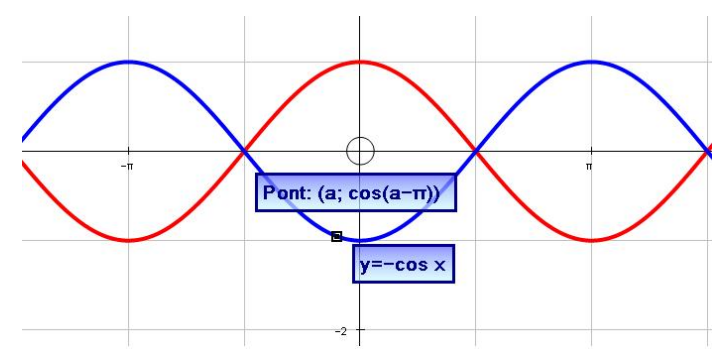

3.24. ábra. A felfedezés: $-\cos x=\cos (x-\pi)$

3.22. Megjegyzés. A fenti felfedezésekben a tanár szerepe nem klasszikus. Feladata elsôsorban a kísérlet előkészítése: az $y=-\cos x$ és az $y=\cos (x-\pi)$ görbék kirajzoltatása, majd ez utóbbi elrejtése, $s$ végül a pont animációjának paraméterezése a rejtett görbe mentén. Ezek után a felfedezésekben már csak katalizátor szerepe van.

\subsubsection{Szintetikus geometria}

A szintetikus geometria tanítása a számos tanagyagreform és -csökkentés hatására jelentôsen karcsúsodott a középiskolában. Az egybevágósági transzformációk kapcsán szinte kizárólag azok tulajdonságait, a hasonlósági transzformációkhoz kötôdôen pedig aritmetikai feladatokat oldunk meg. Szerkesztésekkel egyáltalán nem foglalkozunk, elsősorban idôhiány miatt. A diákok többsége szeretne szerkesztéseket végezni, elsôsorban az általános iskolából származó játékos, pozitív tapasztalatok miatt. Akkor azonban, amikor akár csak egy egyszerúbb szerkesztés tényleges kivitelezésére kerül 
sor, hamar elveszítik türelmüket, a precizitásról nem is beszélve. A szerkesztés egyszerú rajzzá alakul, s sokan nem is látják, értik a különbséget. A szerkesztések kivitelezése hosszadalmas, a figyelmet nagymértékben lekötô folyamat. Nem csak azzal van a baj, hogy erre nincs idő, hanem legfőképpen azzal, hogy a diákok nem látják, hogy a szerkesztés elsősorban egy eszköz a sejtés és a bizonyítás segítésére. A tökéletes pontossággal kivitelezett szerkesztés nem csak sejtetô, de bizonyító erejú is, ilyet azonban hagyományos úton, fôleg a mai, másfajta motorikus rutinokkal rendelkezố gyerekekkel nem tudunk végezni. A megoldást most is a számítógéptól várhatjuk. A GeoGebra program segítségével nem csak, hogy gyorsan és pontosan szerkeszthetünk, de ábráink dinamikusak lesznek, így tulajdonképpen tetszőleges számú szerkesztést hajthatunk végre egyetlen ábra segítségével. Az ábrák mozgatásával, a paraméterek változtatásával, a szerkesztési lépések visszajátszásával elvégezhetô a diszkusszió és felfedezhetô a bizonyítás is. Az alábbiakban három, az elemi síkgeometira különbözố területeirôl származó problémát mutatunk, megoldás gyanánt pedig egy-egy pillanatképet a dinamikus GeoGebra munkalapról, a proof without words égisze alatt. (Egy-egy rövid bekezdés erejéig vázoljuk a deduktív bizonyítások fő gondolatait is.)

3.23. Feladat. Legyen $P$ az $A B C$ háromszög $A B$ oldalának tetszóleges belsố pontja. Jelölje $O_{1}$ és $O_{2}$ az $A P C$, ill. $B C P$ háromszögek köré írható köreinek középpontját. Milyen kapcsolat van az $\mathrm{O}_{1} \mathrm{PO}_{2}$, és az $A B C$ háromszög között? Miért?

\section{Megoldás.}

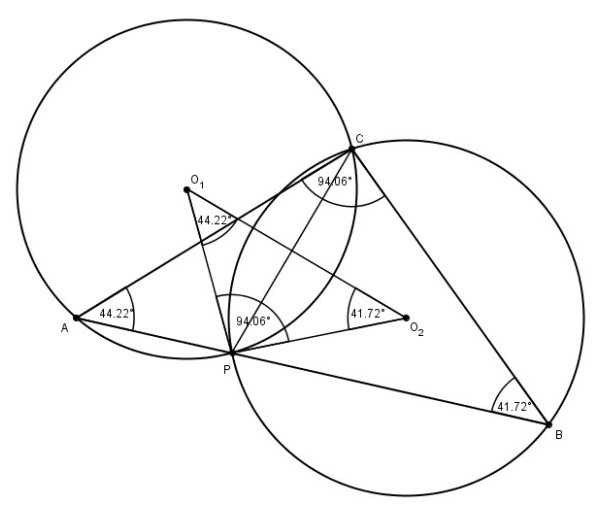

3.25. ábra. A háromszögek hasonlóak

Könnyen látható, hogy az $A P$ és $B P$ szakaszok felezőmerólegesei párhuzamosak egymással. A kerületi és középponti szögek tétele alapján következik, hogy $\mathrm{PO}_{2} \mathrm{C} \measuredangle=$ $2 \cdot P B C \measuredangle$. A $P_{2} C$ háromszög egyenlő szárú, így $O_{1} O_{2}$ e háromszög alaphoz tartozó magassága, s így a háromszög $P_{2} \mathrm{C}$ szögének szögfelezője is. Így kaptuk: $\mathrm{PO}_{2} \mathrm{O}_{1} \measuredangle=$ $P B C \measuredangle$. Teljesen hasonlóan megmutatható, hogy $P_{1} O_{2} \measuredangle=P A C \measuredangle$, ez pedig elegendő a hasonlósághoz. 
3.24. Feladat. Adott a síkon egy $P$ pont és egy $A B C D$ négyszög. Tükrözzük $P$ pontot a négyszög oldalfelezô pontjaira (mindig $P$-t tükrözzük)! A kapott négy pont milyen négyszöget alkot? Miért?

\section{Megoldás.}

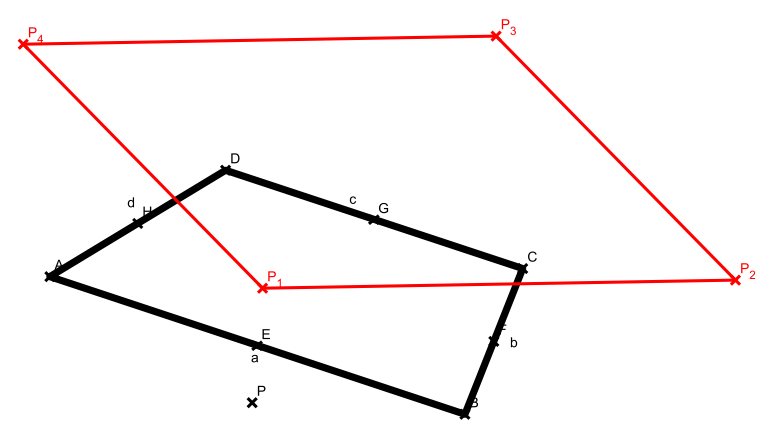

3.26. ábra. A képpontok által kifeszített négyszög ...

A sík egy tetszóleges $O$ pontjából indítsunk helyvektorokat az eredeti, illetve a vizsgált négyszög csúcsaiba, valamint a $P$ pontba, illetve a megfelelő oldalfelezô pontokba. A helyvektorokat jelöljük a szokásoknak megfelelően a végpontjukhoz tartozó betûvel (pl. $\overrightarrow{O P}=\vec{p}$ ). Ekkor, a középpontos tükrözés miatt a következók írhatók:

$$
\begin{aligned}
& \overrightarrow{p_{1}}=\vec{a}+\vec{b}-\vec{p} \\
& \overrightarrow{p_{2}}=\vec{b}+\vec{c}-\vec{p} \\
& \overrightarrow{p_{3}}=\vec{c}+\vec{d}-\vec{p} \\
& \overrightarrow{p_{4}}=\vec{d}+\vec{a}-\vec{p}
\end{aligned}
$$

ahonnan például, $\overrightarrow{p_{1}}-\overrightarrow{p_{2}}=\overrightarrow{p_{4}}-\overrightarrow{p_{3}}$ kapható, ami azt jelenti, hogy a $P_{1} P_{2} P_{3} P_{4}$ négyszög paralelogramma.

3.25. Feladat. Legyen az $A B C$ háromszög beírt körének a háromszög $c$ oldalán lévô érintési pontja $E$. Milyen az $A E C$ háromszög és a $C E B$ háromszög beírt köreinek kölcsönös helyzete? Miért?

Megoldás. Legyen az $A B C$ háromszög beírt körének $A B$ oldalon lévô érintési pontja $E$, valamint a háromszög félkerülete $s$. Jelölje továbbá $e$ az $E C$ szakasz hosszát, $P$ és $Q$ pedig rendre az $E B C$, illetve az $A E C$ háromszögek $E C$ oldalon lévô érintési pontjait. 


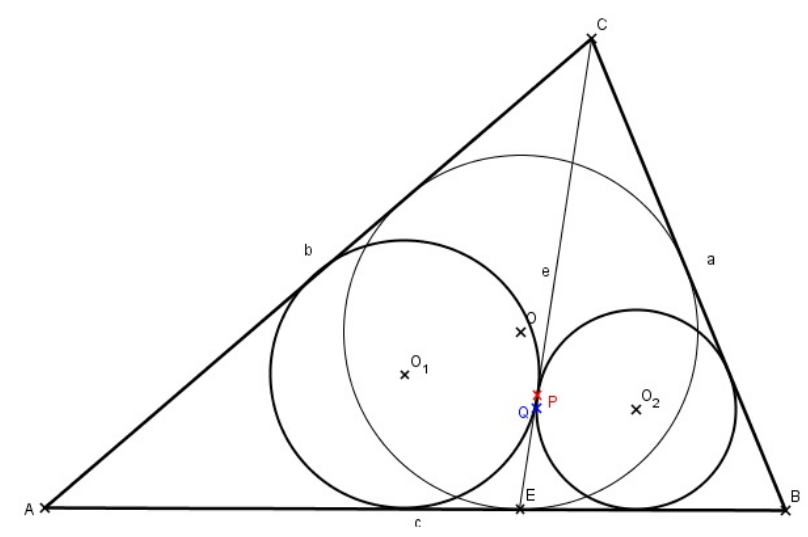

3.27. ábra. A beírt körök érintik egymást

Ekkor, kihasználván a háromszög beírt körének oldalon vett érintési pontjai által meghatározott szakaszok hosszáról ismerteket, tudjuk, hogy $E B=s-b$ illetve, $E A=$ $s-a$. Ugyanezen ismereteket alkalmazva a $C E B$ és $C A E$ háromszögek beírt köreinek $C E$ oldalán lévố érintési pontjaira kapjuk, hogy $E P=\frac{e+a+s-b}{2}-a=\frac{s-a-b+e}{2}$ és $E Q=\frac{e+b+s-a}{2}-b=\frac{s-a-b+e}{2}$, ami azt jelenti, hogy $P=Q$, vagyis a körök érintik egymást.

\subsubsection{Az integrál és a grafikon alatti terület}

Az emelt szintû́ középiskolai analízis, de talán az egyetemi bevezetô kalkulusnak is az egyik legszebb pontja a Newton-Leibniz formula. Az integrál és a grafikon alatti terület közötti kapcsolat azonban egyáltalán nem tartozik a középiskolás fejjel könnyen megérthetô fejezetek közé. Egy lehetséges felépítésben elôször a határozatlan integrál jelenik meg, mint az antideriváltak, (primitív függvények) halmaza. Néhány nélkülözhetetlen integrálási módszer megismerése után következhet először a véges zárt intervallumon értelmezett (nemnegatív korlátos) függvények grafikonja alatti terület vizsgálata. A vizsgált görbevonalú idomok területének meghatározása új módszereket igényel. Kiváló színtere ez a felfedeztetésnek. Az alsó és felső összeg fogalma, illetve ezen összegeknek a beosztás finomításával történố változásának követése nem könnyú. A fentiek precíz leírása is nehéz, és így félő, hogy a diákok fóleg erre koncentrálnak a mögöttes, lényegi tartalom helyett. Ezek után bevezetjük a határozott integrál fogalmát a maga megfoghatatlanságával, majd kapcsolatát a grafikon alatti területtel. A legnehezebb fogalom talán az integrál mint a felsố határ függvénye és végül a NewtonLeibniz formula. Sokat segíthet hát a fogalmak megértésében néhány dinamikus ábra, animáció. Különösen igaz ez akkor, amikor már nem is a grafikon alatti területrôl, hanem például különbözô egyenesek körül megforgatott görbék által alkotott forgástestek térfogatáról, felszínérôl van szó.

A pillanatképpel rögzített elsố dinamikus GeoGebra munkalapon kiválaszthatjuk a függvény típusát, néhány előre megadott közül. Változtathatjuk a beosztás finomsá- 
gát, s közben megfigyelhetjük, hogyan változik az alsó, illetve a felső összeg.

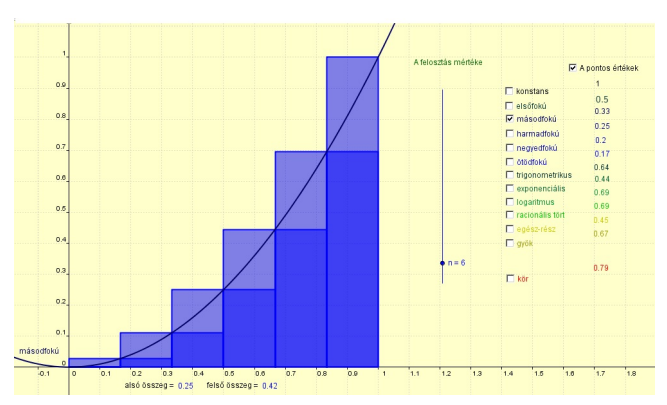

(a)

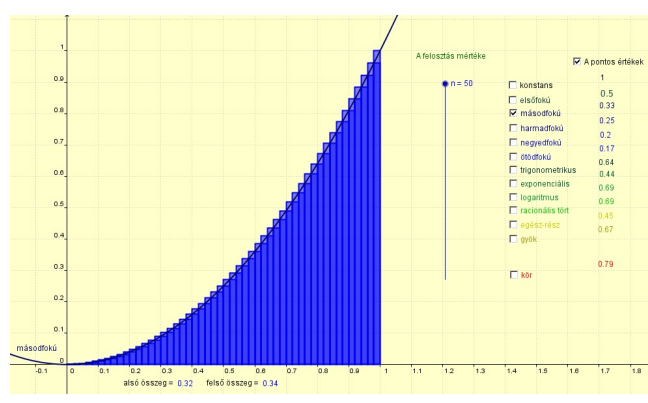

(b)

3.28. ábra. Alsó és felsô összegek és a beosztás finomsága

A második munkalap egy olyan lehetôséget vázol, ahol a felhasználó (felfedezô) maga módosíthatja a függvény hozzárendelési szabályát, az intervallum határait, a beosztás finomságát.

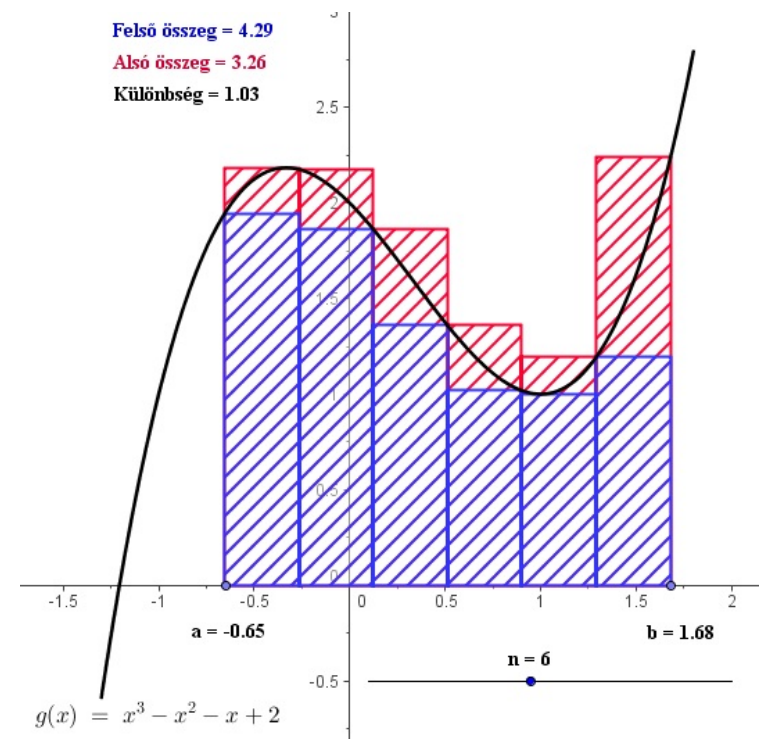

3.29. ábra. Alsó és felsô összegek és a határozott integrál

Az alábbi Autographban készült dinamikus ábrán változtatható a függvény hozzárendelési szabálya, az intervallum mindkét végpontja, a beosztás finomsága, a terület közelítésének módja, a forgatás egyenesének egyenlete. A lassú kirajzolás funkciónak köszönhetôen folyamatában láthatjuk a forgástest létrejöttét, illetve a program bármely paraméter változtatása esetén újra kiszámolja a vizsgált mennyiségeket. Külön érdekes, amikor a beosztás finomságát animálva láthatjuk, hogyan „,simul ki” a forgástest illetve hogyan válik a közelítés mind pontosabbá. 


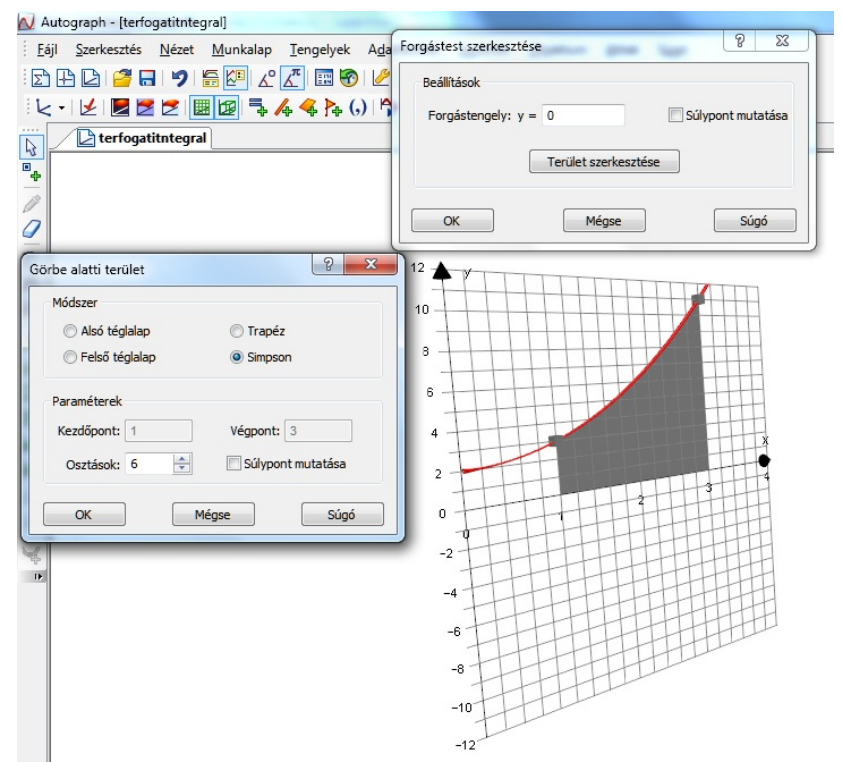

(a)

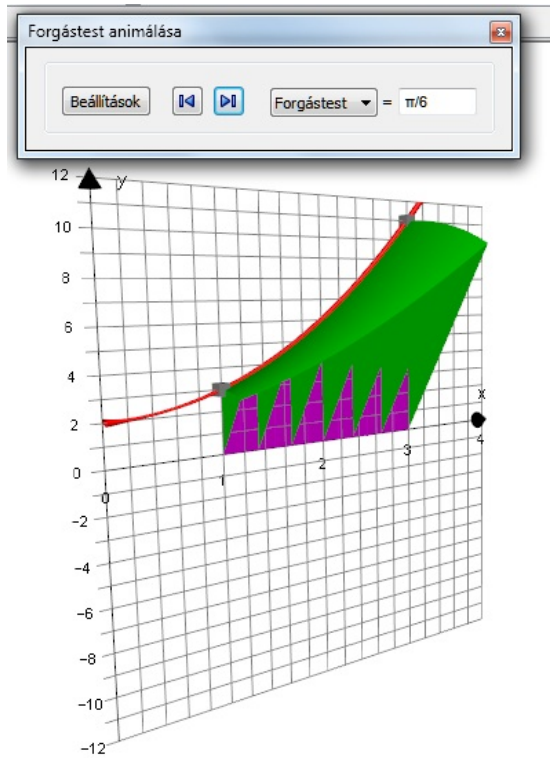

(b)

3.30. ábra. Készül a forgástest

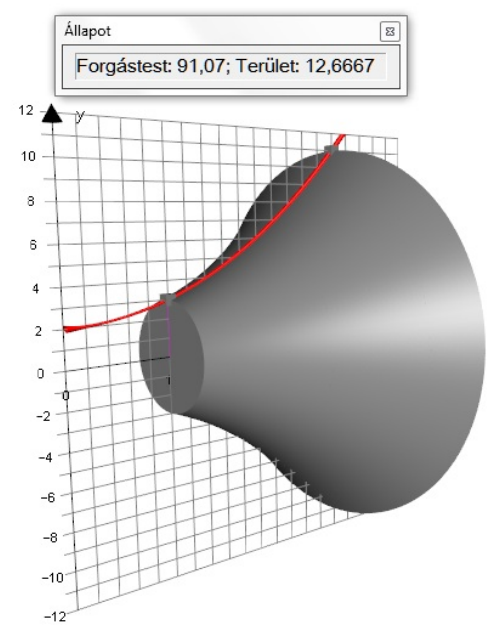

3.31. ábra. A forgástest és jellemzői

A fentiek segítségével lehetôség nyílik arra, hogy a tanulók megtapasztalják a matematikai alkotás folyamatát, s eközben maguk fedezhetik fel az összefüggéseket.

A következőkben egy példán keresztül megmutatjuk, hogyan tárhatjuk fel a számológép „fekete dobozát” a számítógép segítségével.

\subsubsection{Honnan tudja a számológép, mennyi $\cos 30^{\circ}$ ?}

Ha a számítógépeket még nem is, a számológépeket már évtizedek óta a legnagyobb természetességgel használjuk a tanítási órákon. Vannak olyan témakörök, melyekben nem 
is képzelhető el feladatmegoldás számológép nélkül. Szükséges segédeszköz az érettségin is. Bizonyos esetekben a tanár megtiltja (meg szokta tiltani), illetve megtilthatja a használatukat, pl. a továbbhaladás szempontjából nélkülözhetetlen, elsôsorban viszonyítási alapot adó nevezetes szögfüggvényértékek ismerete esetében. Jogosan merül fel a kérdés, hogy ha számológéppel számolunk, az honnan „tudja” a megfelelő értékeket? A kérdés persze feltehetô számos más esetben, pl. a logaritmus, vagy a gyökvonás esetében is. Igen kevéssé valószínú, hogy a gép egységkört rajzolna, a függvény grafikonjáról olvasna le értéket, esetleg az egész függvénytáblázat belé lenne plántálva, s abból keresne. Akkor mégis honnan tudja a számológép, mennyi cos $30^{\circ}$ ?

A kérdésre úgy a legérdemesebb megadni a választ, ha azt a diákjainkkal magunk fedeztetjük fel. A válasz ugyanis egy olyan eszközben rejlik, melyet a késóbbi tanulmányok, illetve hasonló vizsgálatok során haszonnal alkalmazhatnak, s ha azt maguk fedezik fel, akkor bizton emlékezni fognak rá a késóbbiekben is.

Abban a kezdet kezdetén meg kell állapodnunk, hogy fokok helyett több szempontból is kényelmesebb radiánban mérni a szögek nagyságát. Ezáltal a kérdésünk is módosult: Honnan tudja a számológép, mennyi $\cos \frac{\pi}{6}$ ?

Tekintsük a következô táblázatot, s töltsük is ki az üres mezóket.

\begin{tabular}{|c|c|c|c|c|c|c|c|c|}
\hline$x$ & 0 & $\frac{\pi}{6}$ & $\frac{\pi}{3}$ & $\frac{\pi}{2}$ & 2 & 3 & 4 & 8 \\
\hline$T_{2}(x)=1-\frac{x^{2}}{2 !}$ & & & & & & & & \\
\hline$T_{4}(x)=1-\frac{x^{2}}{2 !}+\frac{x^{4}}{4 !}$ & & & & & & & & \\
\hline$T_{6}(x)=1-\frac{x^{2}}{2 !}+\frac{x^{4}}{4 !}-\frac{x^{6}}{6 !}$ & & & & & & & & \\
\hline$T_{8}(x)=1-\frac{x^{2}}{2 !}+\frac{x^{4}}{4 !}-\frac{x^{6}}{6 !}+\frac{x^{8}}{8 !}$ & & & & & & & & \\
\hline \hline $\cos x$ & & & & & & & & \\
\hline
\end{tabular}

3.32. ábra. Felfedezések - a $\cos x$ és a Taylor-polinom. Hol és mennyire jó a közelítés?

A táblázatban a $\cos x 0$ körüli különbözô rendú Taylor-polinomjai találhatók. A táblázatban kiszámolt értékekból kialakítható a sejtés, hogy a polinom a tagok számának növekedésével a 0 pont szúk környezetében viszonylag gyorsan és pontosan közelíti az igényelt függvényértékeket. A 0 ponttól távolodva azonban a közelítés pontossága csökken, egy idő után nem is használható.

\begin{tabular}{|c|c|c|c|c|c|c|c|c|}
\hline$x$ & 0 & $\frac{\pi}{6}$ & $\frac{\pi}{3}$ & $\frac{\pi}{2}$ & 2 & 3 & 4 & 8 \\
\hline$T_{2}(x)$ & 1 & 0,8629221 & 0,4516886 & $-0,2337005$ & -1 & $-3,5$ & -7 & -31 \\
\hline$T_{4}(x)$ & 1 & 0,8660538 & 0,5017962 & 0,0199689 & $-0,3333333$ & $-0,125$ & 3,6666667 & 139,666667 \\
\hline$T_{6}(x)$ & 1 & 0,8660252 & 0,4999645 & $-0,00008945$ & $-0,4222222$ & $-1,1375$ & $-2,0222222$ & $-224,42222$ \\
\hline$T_{8}(x)$ & 1 & 0,8660254 & 0,50000004 & 0,0000247 & $-0,415873$ & $-0,9747767$ & $-0,3968254$ & 191,67937 \\
\hline \hline $\cos x$ & 1 & 0,8660254 & 0,5 & 0 & $-0,4161468$ & $-0,9899925$ & $-0,6536436$ & $-0,1455$ \\
\hline
\end{tabular}

3.33. ábra. Felfedezések - a $\cos x$ és a Taylor-polinom. Jó és kevésbé jó közelítések

A fentiek egy egyszerủen elkészíthető GeoGebra alkalmazás segítségével könnye- 
dén szemléltethetôk. Az animációban megváltoztatható a függvény hozzárendelési szabálya, a polinom rendje, valamint a Taylor-polinom felírására szolgáló pont abszcisszája.

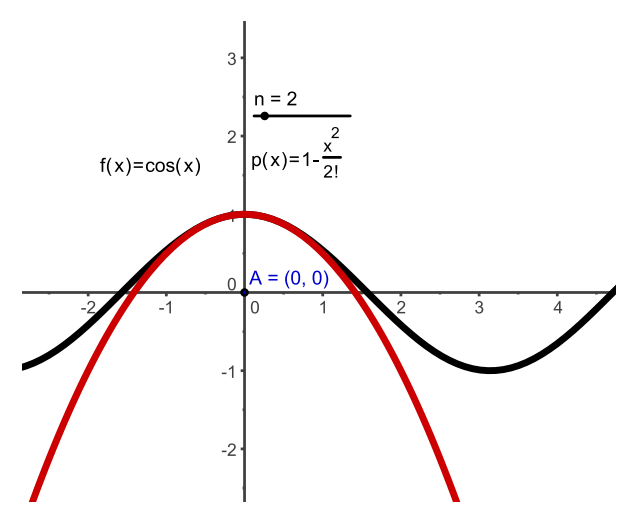

(a)

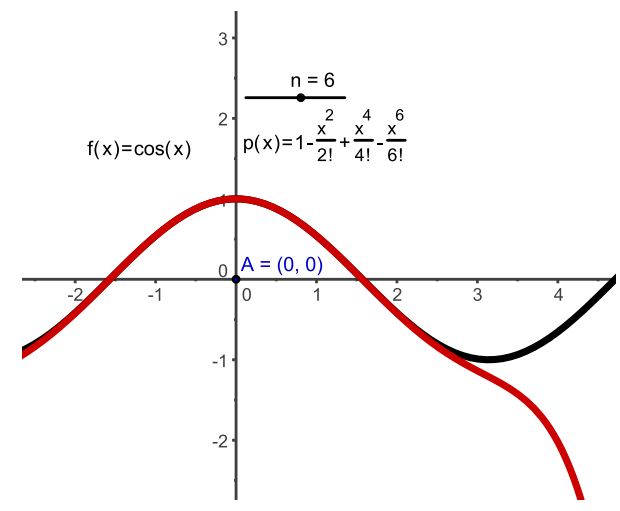

(c)

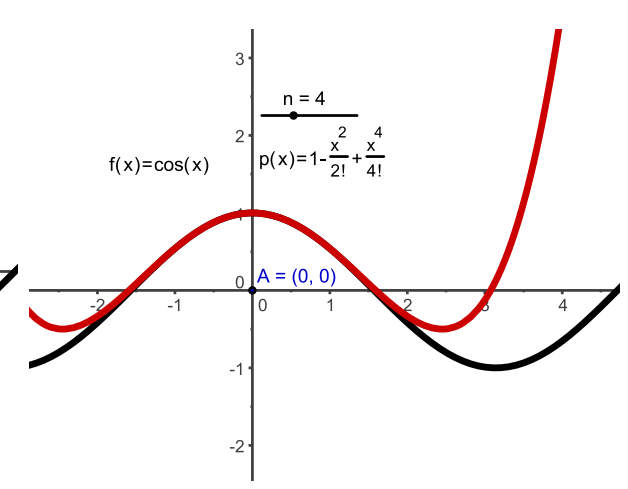

(b)

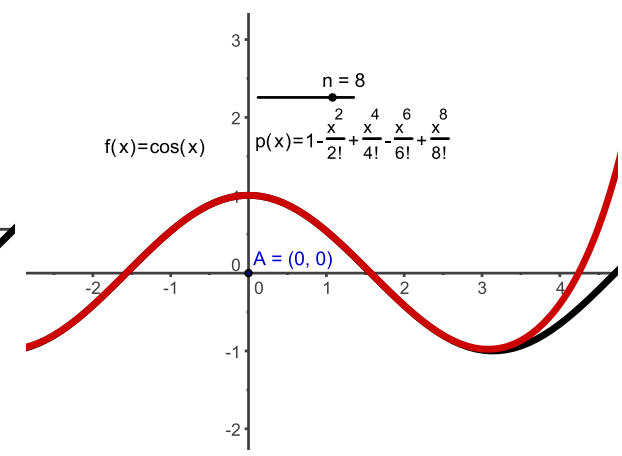

(d)

3.34. ábra. A $\cos x$ és a Taylor-polinom - Miért közelít?

Az adott paraméterek változtatásával felfedeztethetô, hogy a közelítés pontossága függ a pont választásától, illetve a polinom rendjétól. Mivel akár 50-ed rendú polinomot is előállíthatunk (és ez már meggyôzốen közelít, tág intervallumban) megfogalmazódhat a Taylor-sor gondolata is.

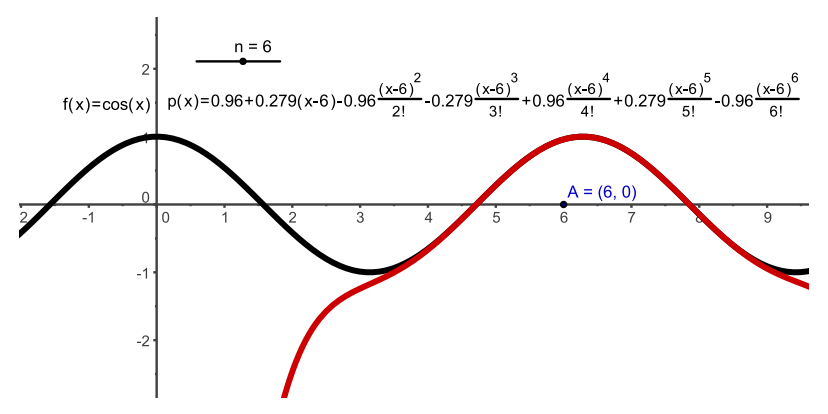

3.35. ábra. Taylor-polinom a 6 körül - jobb közelítés egy másik tartományon 


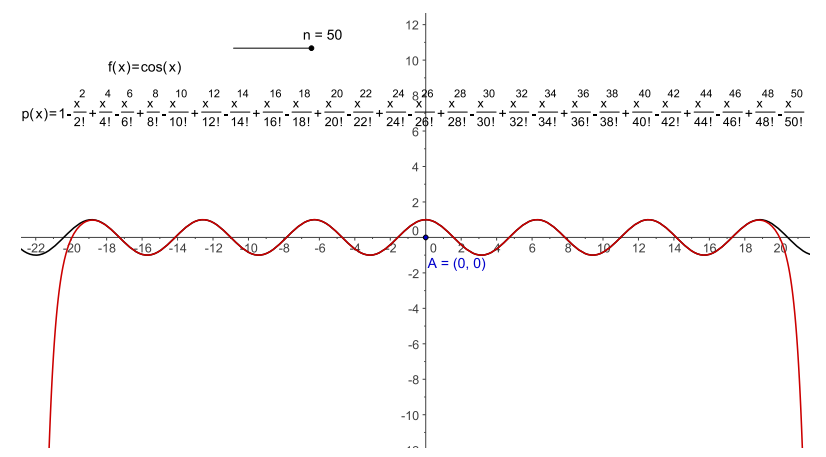

3.36. ábra. Taylor-polinom - (Ugye) mennyire jól közelít?

Mindezek összecsengenek az 1.4.2. fejezetben megfogalmazottakkal is, bizonyítván, hogy felfedezésekkel valóságközeli problémák megoldására vonatkozóan is tehetünk érdemi lépéseket.

3.26. Megjegyzés. A gépi számábrázolás (legyen az számológép vagy számítógép) hibái elvi jellegúek, így azok nem küszöbölhetôk ki.

\subsubsection{Módszertani összefoglaló}

A fejezetben bemutattuk a Magyarországon legelterjedtebb, oktatásban kiválóan használható szoftvereket, (3.4.3.) azok didaktikai előnyeivel együtt. Láthattunk példát az önálló, otthoni tanulást segítő lehetôségekre éppúgy, mint az egyszerú felhasználói felület hatékony kihasználására. Használtuk a számítógépet a kísérletek számának megsokszorozására (3.4.4., 3.4.6.), mellyel a bizonyosság szintjét növeltük. A számítógépes megközelítés játékos formába ágyazásával (3.4.5.) a legkevésbé kedvelt, alacsony hatékonysággal tanított területeken is motiválttá tehetjük diákjainkat. Elértük, hogy a felhasznált eszközök mögé lássunk, apró bepillantást nyerhessünk a matematika valódi múködésébe (3.4.8.). Végül példát láthattunk a bonyolult, a matematikai absztrakció magas fokán álló fogalmakat, összefüggéseket testközelbe hozó reprezentációs lehetôségekre (3.4.7.). 


\section{4. fejezet}

\section{Szigetek}

„Elmondod, elfelejtem. Megmutatod, tán megjegyzem. Ha együtt csináljuk, megértem." (KÍNAI BÖLCSESSÉG)

\subsection{Bevezetés}

Az alábbiakban kísérletet teszünk az előzőekben részletezett módszertani elvek egy konkrét, élő példán keresztül történô komplex reprezentálására. A szigetek néven ismertté vált problémacsoport kapcsán megmutatjuk, hogyan lehetséges számítógéppel katalizált felfedezéseken keresztül eljutni egy intuitív fogalomtól a különbözô absztrakciós szinteken lévô definíciókig. Részletezzük, hogyan segítheti a számítógép a problémafelvetést, a modellalkotást és a mintafelismerést. Lehetôséget mutatunk a bizonyossági szint számítógépes kísérleteken keresztül történő növelésére, valamint a példák és ellenpéldák együttes hatására. Ennek keretében a helyes megoldások mellett az elsô intuíciónak leginkább megfelelő, nem feltétlenül korrekt válasszal szolgáló próbálkozásokat is bemutatunk. Ezek a heurisztikus megközelítések serkentik a kételkedés igényét, valamint a kritikus gondolkodás motorjává is válhatnak. A számítógép segítségünkre lesz a bizonyítási módszerek és a bizonyítás lépéseinek megtalálásában is.

\subsection{Történeti áttekintés}

2007. május 9-én Földes István előadást tartott a Szegedi Tudományegyetem Algebra és Számelmélet Tanszékének szemináriumán Prefixmentes és egyértelmúen dekódolható kódok Kraft-összegeiról címmel. Itt vezette be az egydimenziós sziget fogalmát.

\begin{tabular}{|l|l|l|l|l|l|l|}
\hline 2 & 1 & 2 & 3 & 2 & 1 & 2 \\
\hline
\end{tabular}

4.1. ábra. Szigetek az $1 \times 7$-es rácson 
Egy adott környezetben a létrehozható szigetek maximális száma fontos szerepet játszik jelen tárgyalásmódban a kódok prefixmentességének ellenôrzésében [49]. A cikk jelen tárgykörhöz kapcsolódó eredménye szerint az $1 \times n$-es rácson legfeljebb $n$ szigetünk lehet. (A sziget fogalmát részletesen felépítjük majd a 4.3. fejezetben.)

Ezen eredményt Czédli Gábor hamarosan általánosította két dimenzióra, téglalap alakú szigetekre [34]. Innen tudjuk, hogy az $m \times n$-es rácson a (téglalap alakú) szigetek maximális száma $f(m, n)=\left\lfloor\frac{m n+m+n-1}{2}\right\rfloor$, ahol $\lfloor x\rfloor$ az $x$ valós szám (alsó) egészrészét jelöli.

\begin{tabular}{|c|c||c|c|c|c|c|c|}
\hline \hline 2 & 2 & 1 & 1 & 1 & 1 & 1 & 1 \\
\hline 1 & 1 & 1 & 3 & 1 & 1 & 1 & 2 \\
\hline \hline 2 & 2 & 1 & 2 & 1 & 2 & 1 & 2 \\
\hline \hline 1 & 1 & 1 & 3 & 1 & 1 & 1 & 2 \\
\hline \hline 2 & 2 & 1 & 1 & 1 & 1 & 1 & 1 \\
\hline \hline
\end{tabular}

4.2. ábra. Szigetek két dimenzióban

A bizonyítás során felhasznált jóval korábbi tétel az adott hálóelméleti eredmény elsố hálóelméleten kívüli alkalmazása volt [35].

A cikk a European Journal of Combinatorics címú folyóiratban jelent meg, 2009ben. A téma hamar felkeltette számos matematikus érdeklôdését. Olyannyira, hogy Lengvárszky Zsolt, a Louisiana State University oktatója (a Szegedi Tudományegyetem Bolyai Intézetének korábbi (1985-86) munkatársa) hamarosan ugyanebben a folyóiratban publikált két cikket is a szigetekrôl. Az elsôben a nem bôvíthetô (maximális) szigetrendszerek minimális szigetszámát határozta meg [92]. (Czédli Gábor cikkében valójában a maximális szigetrendszerek maximális szigetszámát adta meg.) Filozófiájukat tekintve Czédli Gábor a legtakarékosabb, Lengvárszky Zsolt a legpazarlóbb sziget elhelyezkedést jellemezte. A másik cikkben a fenti problémakör egy speciális esetét vizsgálva, az $m \times n$-es rácson elhelyezkedố négyzet alakú szigetek által alkotott maximális szigetrendszerek maximális és minimális szigetszámára vonatkozóan tett megállapításokat [93]. Ekkor indult el a szigetek elemi eszközökkel történô szerteágazó vizsgálata is $[11,110,112]$. Megkezdődött a háromszögrács szigeteinek vizsgálata, de egy jó felsô, illetve alsó korlát megtalálása után ez félbeszakadt [70]. Konkrét, zárt formula a négyzet alakú szigetek maximális száma esetében sem született [71]. Történtek vizsgálatok magasabb dimenziókban is [133].

Sokkal nehezebb problémába ütköztünk a szerzô által elindított korlátozott magasságú szigetek vizsgálata során, itt egyelôre csak néhány speciális esetre vonatkozó részeredményünk van [72, 111] (Eszter K. Horváth, Attila Máder, Andreja Tepavčević. One-dimensional Czédli-type Islands, The College Mathematical Journal, 42(5), 374378, 2011., Attila Máder, Géza Makay. The maximum number of rectangular islands, The Teaching of Mathematics, 14(1), 31-44, 2011.).

A problémakör létjogosultságát nem csak a publikációk magas száma mutatja, 
hanem az is, hogy a szigetek ,sikere” további hálóelméleti vizsgálatokat motivált [36, 37]. Ugyanakkor a matematika különálló területei közötti oly fontos hidak egyikét is jelentheti a szigetek új szemléletú, folytonos esetben történố vizsgálata [95, 129].

\subsection{A sziget fogalmának kialakítása}

„... a matematikai fogalmakat hosszú idôn át érleljük, s csak azután jutunk el a matematikailag kialakítandó fogalomhoz." (SzENDREI JÁNOS)

Ebben a részben az önálló felfedezést segítő, tudatos tanári munkával irányított feladatokkal kísérletet teszünk a sziget fogalmának további, tetszóleges mélységú matematikai vizsgálat elvégzésére alkalmas, különbözô absztrakciós szintú kialakítására. Ezzel is igazolván, hogy felfedezésekkel nem csak a sejtések, de a fogalmak kialakításának szintjén is eredményes munka végezhetô.

\subsubsection{Mi az a sziget?}

Egy probléma megközelítése során fontos, hogy mindig úgy vezessük be azt, hogy felkeltsük a tanulók érdeklődését. Erre alkalmas lehet néhány kép, ábra, karikatúra; illetve különösen hasznos, ha más tudományterületekre, más tantárgyaknál már tanult ismeretekre utalunk. A modell-, illetve fogalomalkotás kezdeti szakaszában különösen ügyeljünk arra, hogy fogalmaink intuitívak, a formalizmust a lehető legteljesebb mértékben nélkülözők legyenek.

4.1. Feladat. Mi a sziget?

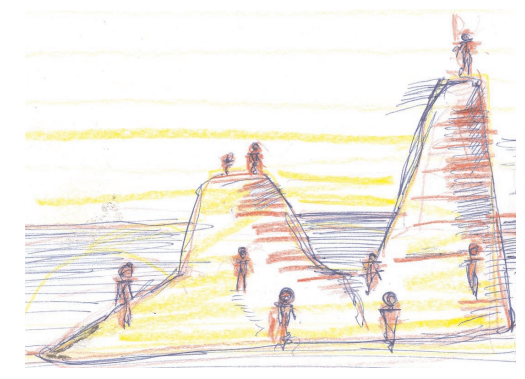

4.3. ábra. Mi a sziget?

A választ például a földrajz órán tanultakat felhasználva, így adhatjuk meg.

4.2. Definíció. A sziget vízzel teljesen körbezárt kisebb szárazföld. 
A tanár szerepe itt annyi, hogy a diákokat egy konkrétabb, megfogható fogalmakat és tulajdonságokat használó definíció megalkotására ösztönözze. A cél ezzel persze egy matematikai modell megalkotása. A szigetet szigetté tevô, lényegi (definiáló) tulajdonságát kiemelve például a következô definíciót kaphatjuk.

4.3. Definíció. Egy sziget kiemelkedik a tengerből; minden pontja magasabb, mint közvetlen környezete bármely pontja.

4.4. Megjegyzés. Ezzel kizártuk vizsgálataink köréből azokat a szigeteket, melyek nem összefüggók, illetve amelyek belsejében vannak környezetüknél mélyebb területek, tavak. A továbbiakban tehát csak tómentes szigetekkel fogunk foglalkozni. A felépítés egy másik módja, illetve új kutatási, felfedezési irány lehet az, ha ilyen szigeteket is megengedünk.

A szigetek reprezentálására természetes eszközként rendelkezésünkre áll a négyzetrácsos papír. Az ebben rejlô lehetôségekre felhívva tanulóink figyelmét, terelhetjük őket egy újabb, jobban használható definíció megalkotása felé.

4.5. Feladat. Hogyan jeleníthetô meg a sziget egyszerú, kezelhetô formában, csak a lényegi tulajdonságát megtartva? Milyen (matematikai) modellt tudnánk adni a szigetre?

Megoldás. Egy lehetséges választás a következô. Legyen leegyszerúsített világunk a négyzetrács egy téglalapja. Az egységnégyzetekből álló téglalap minden mezôjéhez hozzárendelünk egy pozitív egész számot, a mezô magasságát. Minden, a téglalapunkon kívüli mezố magasságát (azaz a vízszintet) 0-nak vesszük.

\begin{tabular}{|l|l|l|l|l|l|}
\hline 4 & 4 & 4 & 1 & 4 & 4 \\
\hline 3 & 4 & 3 & 1 & 5 & 4 \\
\hline 1 & 5 & 1 & 1 & 2 & 2 \\
\hline 3 & 4 & 3 & 1 & 3 & 3 \\
\hline
\end{tabular}

4.4. ábra. Leegyszerúsített világunk

4.6. Megjegyzés. Az, hogy a mezôk értékét pozitív egésznek választottuk, önkényesnek túnhet. Könnyen meggondolható azonban, hogy felesleges valós számokat megengedni magasságnak. Ugyanis a meglévő magasságokat nagyság szerint növekvő módon sorba rendezve, az elsố helyett egyet, a második helyett kettőt, s.í.t. írva, ugyanazokat a szigeteket kapjuk, s csak pozitív egész értékeket használunk. Mivel a rácsunk véges, ez mindig megtehetô.

Távlati célunk a szigetek számának vizsgálata, így a fogalom kialakítását is ennek rendeljük alá. A következô néhány, a szigetek számára vonatkozó feladat célja, hogy az intuitív után egy, a további vizsgálatok szempontjából használható, kevésbé általános, konkrétabb fogalmat alapozzanak meg. 


\subsubsection{Keressünk szigeteket!}

4.7. Feladat. Keressük meg az alábbi ábrákon az összes szigetet!

\begin{tabular}{|l|l|l|}
\hline 3 & 3 & 2 \\
\hline 3 & 2 & 2 \\
\hline
\end{tabular}

(a)

\begin{tabular}{|l|l|l|l|}
\hline 4 & 3 & 1 & 2 \\
\hline 5 & 2 & 1 & 3 \\
\hline 4 & 4 & 1 & 4 \\
\hline
\end{tabular}

(b)

\begin{tabular}{|l|l|l|l|l|l|}
\hline 4 & 4 & 4 & 1 & 4 & 4 \\
\hline 3 & 4 & 3 & 1 & 5 & 4 \\
\hline 1 & 5 & 1 & 1 & 2 & 2 \\
\hline 3 & 4 & 3 & 1 & 3 & 3 \\
\hline
\end{tabular}

(c)

4.5. ábra. Keressük meg a szigeteket!

Megoldás. A 4.5(a) ábrán két sziget van. Egyrészt a teljes rács sziget, hiszen mint minden esetben, most is eleget tesz a definíciónak. A továbbiakban a teljes rácsot fôszigetnek nevezzük. Másrészt a bal oldalon van egy fordított $L$-alakú szigetünk, melyben minden mezô magassága 3. Mivel a fôsziget mindig sziget, azt a továbbiakban általában nem jelöljük. A 4.5(b) ábrán és a 4.5(c) ábrán is nyolc sziget található.

\begin{tabular}{||l|l|l|}
\hline 3 & 3 & 2 \\
\cline { 2 - 3 } 3 & 2 & 2 \\
\hline
\end{tabular}

(a)

\begin{tabular}{||||c|c||c||c||}
\hline \hline 4 & 3 & 1 & 2 \\
\hline 5 & 2 & 1 & 3 \\
\hline & & & \\
4 & 4 & 1 & 4 \\
\hline \hline
\end{tabular}

(b)

\begin{tabular}{||c|c|c||c||c|c||}
\hline \hline 4 & 4 & 4 & 1 & 4 & 4 \\
\cline { 1 - 1 } 3 & 4 & 3 & 1 & 5 & 4 \\
\hline 1 & 5 & 1 & 1 & 2 & 2 \\
\hline 3 & 4 & 3 & 1 & 3 & 3 \\
\hline
\end{tabular}

(c)

4.6. ábra. Szigetek tetszóleges alakkal

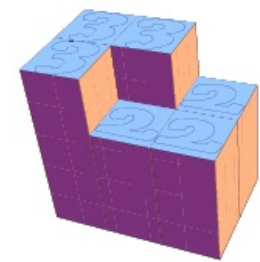

(a)

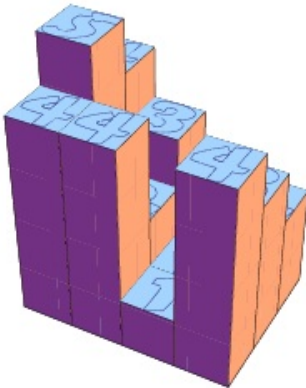

(b)

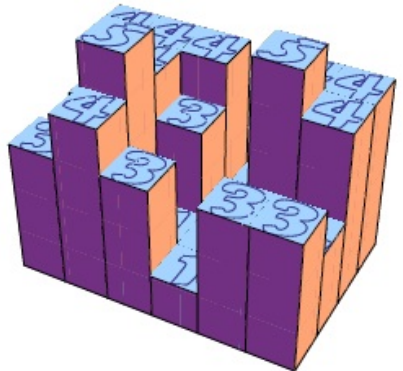

(c)

4.7. ábra. Szigetek tetszóleges alakkal 
A fenti kétdimenziós ábrák egy egyszerú program, míg a háromdimenziós reprezentációk a Mathematica komputer-algebrai rendszer segítségével készültek. A számítógéppel támogatott oktatás számos elônye megmutatkozik már ezekben az egyszerú ábrákban is: a kétdimenziós ábra könnyen sokszorosítható, kivetíthető, azon a szigetek könnyen jelölhetők. A háromdimenziós ábrák forgathatók, teljesebb vizuális képet adnak. Ábrákat természetesen akár egy egyszerú képszerkesztô programmal is készíthetünk. Több ábra generálásával, könnyedén katalizálhatjuk felfedezéseinket. Elérhetjük például a kísérletek megsokszorozását, amikor is minden tanuló (csoport) különböző ábrát kapva, ugyanazon a problémán, de mégis különböző feladaton dolgozik.

A fenti rövid kísérletsorozatnak is számos eredménye van. Megismertük, kialakítottuk a fôsziget fogalmát, továbbá megtapasztalhattuk, hogy szigeteink túlságosan is sokfélék lehetnek, összeszámlálásuk nehézkes. Nehézkes, sôt lehet, hogy felesleges is, hiszen akár a világunk mérete által maximálisan elérhetô, $m \times n$-es rács esetén $m n$, számú szigetet is elő tudunk állítani. Így még összeszámlálásuk sem érdekes. A következókben ennek járunk utána. Az általános, paramétereket tartalmazó vizsgálat előtt most is konkrét, kis rácsokon érdemes próbálkozni, az önálló tanulói aktivitást szem előtt tartva.

4.8. Feladat. Adjunk meg magasságokat a $2 \times 3$-as rácson úgy, hogy azon pontosan 6 szigetünk legyen!

\section{Megoldás.}

\begin{tabular}{|l|l|l|}
\hline 1 & 2 & 3 \\
\hline 4 & 5 & 6 \\
\hline
\end{tabular}

(a)

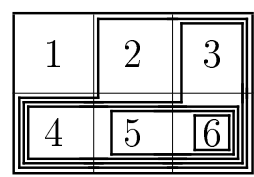

(b)

4.8. ábra. Kis rács, sok sziget

A fenti természetesen csak egy lehetséges konfiguráció, de már ez is alapul szolgálhat számos, különbözô irányba történô általánosításhoz. Egy ilyenre példa a következô. 
4.9. Feladat. Adjunk meg magasságokat az $m \times n$-es rácson úgy, hogy azon pontosan $m n$ szigetünk legyen!

Megoldás. Egy lehetséges megoldást mutat az alábbi ábra.

\begin{tabular}{|c|c|c|c|c|}
\hline 1 & 2 & $\cdots$ & $\cdots$ & $n$ \\
\hline$n+1$ & $n+2$ & $\cdots$ & $\cdots$ & $2 n$ \\
\hline $2 n+1$ & $2 n+2$ & $\cdots$ & $\cdots$ & $3 n$ \\
\hline$\ldots$ & $\cdots$ & $\cdots$ & $\cdots$ & $\cdots$ \\
\hline$\ldots$ & $\ldots$ & $\cdots$ & $m n-1$ & $m n$ \\
\hline
\end{tabular}

4.9. ábra. Nagy rács, sok sziget $-m n$ sziget az $m \times n$-es rácson

Ezen konfigurációban a magasságok a sorokban balról jobbra haladva szigorú monoton növekvô sorozatot alkotnak.

A fentiekkel célunk a tanulók általunk preferált szigetfogalom irányába történô terelése úgy, hogy kísérleteinken keresztül ez egy általuk megtalált természetes választásnak tûnjön. Eddigi vizsgálataink következményeként a tanulók maguk ismerhetik fel tehát, hogy speciális alakú szigetekkel érdemes csak foglalkoznunk. A korábbiak után egy természetes választás a téglalap alakú sziget.

Ezek után feladatként is kitûzhető fogalmunk további absztrahálása.

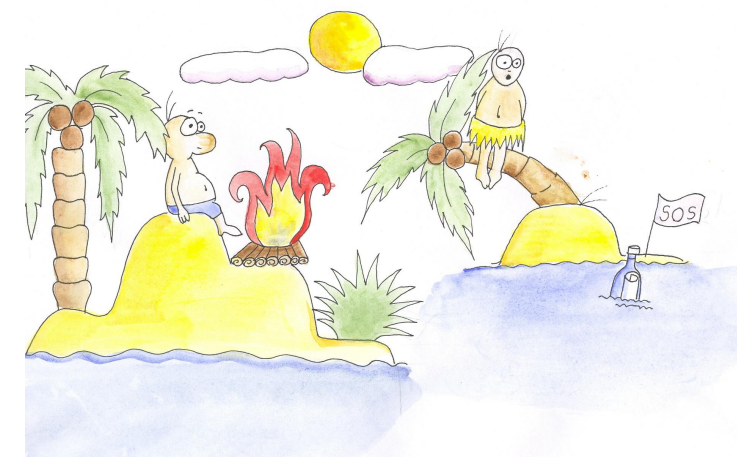

(a) Szigetek múvész szemmel
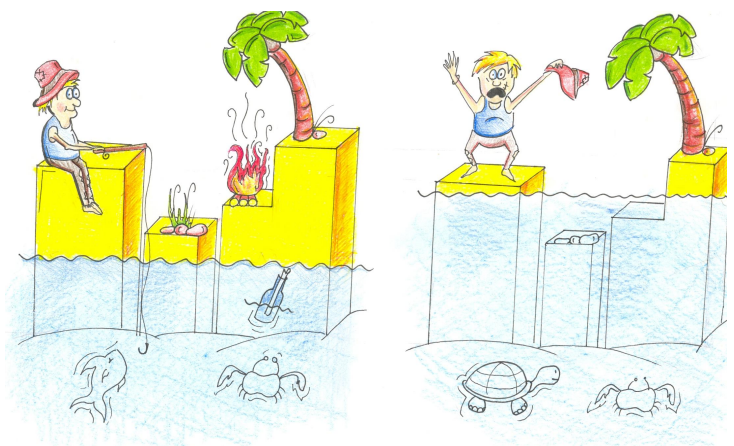

(b) Szigetek, egy kicsit matematikus szemmel

4.10. ábra. Szigetek absztrahálódása

4.10. Feladat. Adjunk definíciót a téglalap alakú sziget fogalmára!

Megoldás. Korábbi vizsgálatainkban szerzett tapasztalatainkat felhasználva például a következô definíciók születhetnek. 
4.11. Definíció. Legyen adott egy $m \times n$-es (négyzet)rács, melynek minden mezójéhez hozzárendelünk egy pozitív egész számot, a mezô (tengerszint feletti) magasságát. Rácsunk egy téglalap alakú tartományát szigetnek nevezzük, ha van olyan vízmagasság, amely esetén a téglalap (szigetként) kiemelkedik a „vízbooll”.

Az absztrakció különbözô szintjén más-más, ekvivalens definíciók is megadhatók. Ha matematikai tartalommal töltjük meg a miért emelkedik ki kérdését, akkor például a következő definíciót kaphatjuk.

4.12. Definíció. Legyen adott egy $m \times n$-es (négyzet)rács, melynek minden mezójéhez hozzárendelünk egy pozitív egész számot, a mezô magasságát. Rácsunk egy téglalap alakú tartományát szigetnek nevezzük, ha minden cellájának magassága nagyobb, mint a téglalapot határoló mezôk bármelyikének magassága.

Ez a definíció tulajdonképpen elegendően konkrét és pontos további vizsgálataink elvégzéséhez. A következô, elsô látásra szükségtelenül bonyolult definíció jelentôségét például az is adja, hogy ezzel a megközelítéssel válik a problémakör programozhatóvá, ami viszont a késóbbi vizsgálatokban fontos szerepet fog játszani.

4.13. Definíció. Legyen $A=\left(a_{i j}\right)_{m \times n}$ egy $m \times n$-es pozitív egész számokat tartalmazó mátrix és $\alpha, \beta, \gamma, \delta$ pozitív egészek, melyekre $1 \leq \alpha \leq \beta \leq m$, illetve $1 \leq \gamma \leq \delta \leq n$. Ekkor azon $a_{i j}$ elemek által alkotott $R$ részmátrixot, melyekre $\alpha \leq i \leq \beta$ és $\gamma \leq j \leq \delta$ mátrixunk egy téglalapjának nevezzük. Legyen $r R$ legkisebb eleme, illetve legkisebb elemeinek egyike. Ekkor, ha az $A$ mátrix bármely, $R$-rel szomszédos $a_{i j}$ elelmére $a_{i j}<r$, akkor azt mondjuk, hogy $R$ (téglalap alakú) sziget $A$-n.

A fentiek alapján természetes, hogy a továbbiakban, ha csak mást nem mondunk, szigeten téglalap alakú szigetet értünk.

4.14. Megjegyzés. A fentiekból látható, hogy hogyan lehetséges a felfedezések középpontba állításával, irányított kísérletekkel segíteni az önálló fogalomalkotás folyamatát.

A következőkben a megalkotott definíciónk alkalmazási lehetôségeit mutatjuk be; célunk a fogalom elmélyítése. Különösen fontos ugyanis, hogy fogalmaink felhasználásának tekintetében addig ne lépjünk tovább, míg fogalmaink meg nem szilárdultak. 
4.15. Feladat. Keressük meg az összes szigetet az alábbi rácsokon!

\begin{tabular}{|l|l|l|}
\hline 3 & 3 & 2 \\
\hline 3 & 2 & 2 \\
\hline
\end{tabular}

(a)

\begin{tabular}{|l|l|l|l|}
\hline 4 & 3 & 1 & 2 \\
\hline 5 & 2 & 1 & 3 \\
\hline 4 & 4 & 1 & 4 \\
\hline
\end{tabular}

(b)

\begin{tabular}{|l|l|l|l|l|l|}
\hline 4 & 4 & 4 & 1 & 4 & 4 \\
\hline 3 & 4 & 3 & 1 & 5 & 4 \\
\hline 1 & 5 & 1 & 1 & 2 & 2 \\
\hline 3 & 4 & 3 & 1 & 3 & 3 \\
\hline
\end{tabular}

(c)

4.11. ábra. Keressük meg az összes (téglalap alakú) szigetet!

Megoldás. A megoldások az alábbi ábrán láthatók. Az elsô ábrán csak egy sziget van, a fôsziget. A második és a harmadik ábrán pedig hat szigetünk van. Érdemes ezt összevetni a 4.7. feladat eredményével.

\begin{tabular}{|l|l|l|}
\hline 3 & 3 & 2 \\
\hline 3 & 2 & 2 \\
\hline
\end{tabular}

(a)

\begin{tabular}{||c|c|c||c||}
\hline 4 & 3 & 1 & 2 \\
\hline 5 & 2 & 1 & 3 \\
\hline 4 & 4 & 1 & 4 \\
\hline
\end{tabular}

(b)

\begin{tabular}{|l|l|l|l|||c|c||}
\hline 4 & 4 & 4 & 1 & 4 & 4 \\
\hline 3 & 4 & 3 & 1 & 5 & 4 \\
\hline 1 & 5 & 1 & 1 & 2 & 2 \\
\hline 3 & 4 & 3 & 1 & 3 & 3 \\
\hline
\end{tabular}

(c)

4.12. ábra. A téglalap alakú szigetek

4.16. Megjegyzés. Az azonos feladat különbözô szemléletú megoldása (4.7., 4.15. feladat) hatékony eszköze a fogalom letisztázásának, elmélyítésének.

A sziget fogalmának elmélyítése kapcsán különösen fontos a szigetkeresés lehetséges inverzproblémáinak vizsgálata. A következőkben erre mutatunk néhány példát.

\subsubsection{Csináljunk szigeteket!}

Eddigi feladatainkban egy adott rácson kellett megtalálnunk az összes szigetet. Tekintsük ezen keresés egyik lehetséges megfordítását! 
4.17. Feladat. Adjuk meg a mezók magasságértékeit úgy, hogy pontosan a jelölt téglalapok legyenek szigetek!

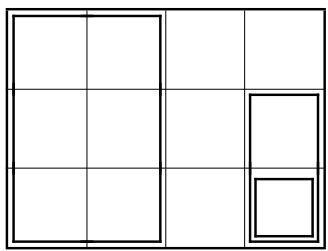

(a)

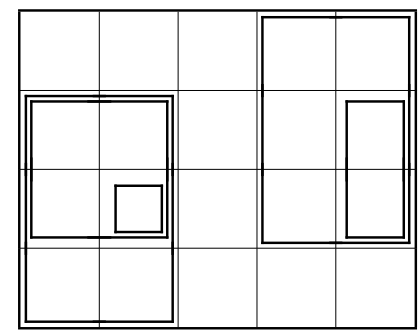

(b)

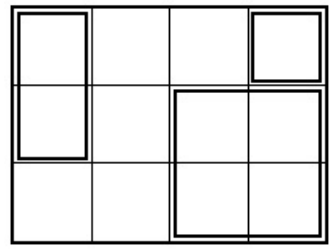

(c)

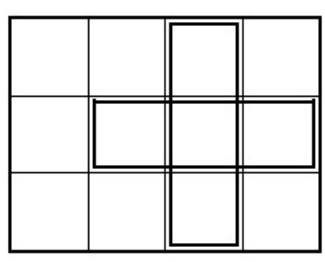

(d)

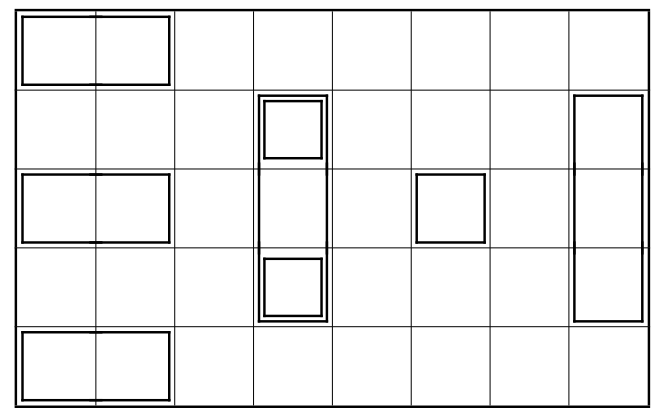

(e)

4.13. ábra. Adjuk meg a magasságokat!

Megoldás. A 4.13(c) és a 4.13(d) ábrákhoz hosszabb próbálkozás után sem találunk megoldást. Az ilyen paradox helyzetek segíthetnek el bennünket a szigetrendszerek szerkezetére vonatkozó felfedezésekig. Már ezen néhány példából is kialakulhat a sejtés, hogy két sziget nem metszheti, sôt nem is érintheti egymást, hacsak nem tartalmazza teljes egészében egyik a másikat. Ezt a 4.52. sejtés keretében be is fogjuk bizonyítani. A 4.13(a), 4.13(b) és a 4.13(e) ábrákhoz az alábbiakban adunk meg egy-egy lehetséges megoldást.

\begin{tabular}{||l|l|l|l||}
\hline 3 & 3 & 2 & 2 \\
\hline 3 & 3 & 2 & 3 \\
\hline 3 & 3 & 2 & 5 \\
\hline
\end{tabular}

(a) Megoldás 4.13(a)

\begin{tabular}{||c|c|c|c|c||}
\hline 1 & 1 & 1 & 3 & 3 \\
\hline \hline 5 & 5 & 1 & 3 & 5 \\
5 & 7 & 1 & 3 & 5 \\
\hline 3 & 3 & 1 & 1 & 1 \\
\hline
\end{tabular}

(b) Megoldás 4.13(b)

\begin{tabular}{|c|c|c|c|c|c|c|c||}
\hline 2 & 2 & 1 & 1 & 1 & 1 & 1 & 1 \\
\hline 1 & 1 & 1 & 3 & 1 & 1 & 1 & 2 \\
\hline 2 & 2 & 1 & 2 & 1 & 2 & 1 & 2 \\
\hline 1 & 1 & 1 & 3 & 1 & 1 & 1 & 2 \\
\hline \hline 2 & 2 & 1 & 1 & 1 & 1 & 1 & 1 \\
\hline
\end{tabular}

(c) Megoldás 4.13(e)

4.14. ábra. A 4.17. feladat megoldásai 
4.18. Megjegyzés. Ott, ahol van megoldás, végtelen sok megoldás van, hiszen valamely téglalap alakú sziget minden mezőjének magasságát azonos értékkel megnövelve a szigetek nem változnak, csak a magasságuk. Az ilyen, nem egyértelmú megoldással rendelkező feladatok különösen fontosak a sziget fogalmának kialakításában, hiszen rajtuk keresztül épp a sziget lényegi, definiáló tulajdonságát tudjuk megvilágítani.

A megoldások iránymutató tanári vezetéssel történő vizsgálata egy, a továbbiak szempontjából fontos, de önmagában is érdekes fogalomhoz vezet el. Az alábbiakban ezt építjük fel.

\subsubsection{Minimális magasságú szigetek, szigetek kanonikus rep- rezentációja}

4.19. Feladat. Adjunk meg további megoldásokat a 4.17 (a) és (b) feladatokhoz.

Megoldás. A következókben két-két megoldást adunk meg a 4.13(a) és 4.13(b) ábrákhoz.

\begin{tabular}{||l|l|l|l||}
\hline 4 & 4 & 2 & 1 \\
\hline 4 & 4 & 2 & 4 \\
\hline 4 & 4 & 2 & 5 \\
\hline
\end{tabular}

(a) Megoldás 4.13(a)

\begin{tabular}{||c|c|c|c|c||}
\hline 1 & 1 & 1 & 3 & 4 \\
\hline \hline 4 & 4 & 1 & 4 & 5 \\
4 & 5 & 1 & 4 & 5 \\
\hline 3 & 3 & 1 & 1 & 1 \\
\hline
\end{tabular}

(c) Megoldás 4.13(b)

\begin{tabular}{||l|l|l|l|}
\hline 3 & 3 & 2 & 2 \\
\hline 3 & 3 & 2 & 3 \\
\hline 3 & 3 & 2 & 4 \\
\hline
\end{tabular}

(b) Megoldás 4.13(a)

\begin{tabular}{||c|c|c|c|c||}
\hline 2 & 2 & 2 & 3 & 3 \\
\hline \hline 4 & 4 & 2 & 3 & 4 \\
\hline 4 & 5 & 2 & 3 & 4 \\
\hline 3 & 3 & 2 & 2 & 2 \\
\hline
\end{tabular}

(d) Megoldás 4.13(b)

4.15. ábra. Magasságok másképp

A számos helyes, de nem azonos megoldás összehasonlítása során könnyedén felmerülhet a felhasználandó magasságértékek vizsgálata.

4.20. Feladat. Mi a közös a fenti megoldásokban?

Megoldás. Bizonyos mezôk magasságai csökkenthetôk úgy, hogy a szigetrendszer nem változik abban az értelemben, hogy pontosan ugyanazok a téglalapok maradnak szi- 
getek. A 4.15(a) ábra esetében például az alábbi ábra mutatja a mezók magasságának csökkentésével előálló új lehetôséget. A megváltozott magasságokat vastagon szedtük.

\begin{tabular}{||l|l|l|l||}
\hline \hline $\mathbf{3}$ & $\mathbf{3}$ & 2 & 1 \\
\hline $\mathbf{3}$ & $\mathbf{3}$ & 2 & 4 \\
\hline $\mathbf{3}$ & $\mathbf{3}$ & 2 & 5 \\
\hline
\end{tabular}

4.16. ábra. Magasságok csökkentése

4.21. Megjegyzés. A fenti mellett számos más megoldás is adható. Ezen a ponton is külön felhívjuk a figyelmet a fokozatosság elvére. Nem célunk rögtön, hogy a minimális megoldást találjuk meg. Elôször elég, ha a diákok azt veszik észre, hogy vannak olyan mezôk, amelyek magasságai csökkenthetôk. Ez az észrevétel a korábbiak után természetes. Ha ugyanis a magasságok növelhetôk a szigetrendszer megváltoztatása nélkül (4.18. megjegyzés), akkor az is előfordulhat persze, hogy csökkenthetôk.

Innen már természetes a minimális magasságokkal dolgozó eset vizsgálata.

4.22. Feladat. Oldjuk meg a 4.17 (a) és (b) feladatokat úgy, hogy a lehetô legkisebb magasságértékeket használjuk fel.

Megoldás. A 4.13(a) és 4.13(b) ábrákhoz tartozó minimális magasságokkal dolgozó megoldásokat az alábbi ábrákon láthatjuk.

\begin{tabular}{||l|l|l|l||}
\hline 2 & 2 & 1 & 1 \\
\hline 2 & 2 & 1 & 2 \\
\hline 2 & 2 & 1 & 3 \\
\hline
\end{tabular}

(a) Megoldás 4.13(a)

\begin{tabular}{||c|c|c|c|c||}
\hline 1 & 1 & 1 & 2 & 2 \\
\hline \hline 3 & 3 & 1 & 2 & 3 \\
3 & 4 & 1 & 2 & 3 \\
\hline 2 & 2 & 1 & 1 & 1 \\
\hline
\end{tabular}

(b) Megoldás 4.13(b)

4.17. ábra. Minimális magasságok 
4.23. Feladat. Egy ilyen, minimális kitöltés esetében hogyan állapítható meg egyszerúen egy adott mezô magassága?

Megoldás. Könnyen látható, hogy minden mezô magassága az a pozitív egész szám, ahány szigetnek része az adott mező. (Ezt mindenképp érdemes összevetni a 4.36. megjegyzésben foglaltakkal.)

A mezốk magasságának meghatározása kapcsán felmerülhet a szigetmagasság definiálásának igénye. Ezt is feldolgozhatjuk felfedeztetô jelleggel, feladatok segítségével.

4.24. Feladat. Hogyan érdemes definiálni egy adott sziget magasságát?

Megoldás. A sziget magasságára a következő definíció adható.

4.25. Definíció. Egy sziget magassága a mezôi magasságértékeinek minimuma.

Mint minden esetben, így most is érdemes a definíció megszilárdulását feladatokkal segíteni. Az alábbiakban erre láthatunk néhány példát.

4.26. Feladat. Miért nem mezői magasságértékének maximumát választottuk egy sziget magasságának?

Megoldás. A magasságok maximumának nincs ténylegesen köze a szigethez, ez a 4.18. megjegyzés alapján jól látható. A minimum viszont az az érték, melynél egy kicsit alacsonyabb vízszint esetén az adott sziget tényleg szigetként viselkedik.

4.27. Feladat. Határozzuk meg az alábbi ábrán látható szigetrendszer szigeteit, s azok magasságait!

\begin{tabular}{|l|l|l|l|l|}
\hline 3 & 2 & 1 & 5 & 5 \\
\hline 2 & 2 & 1 & 5 & 4 \\
\hline
\end{tabular}

4.18. ábra. Szigetek és magasságaik

Megoldás. A fenti ábra szigeteit az alábbiakban jelöltük. A bal oldali $1 \times 1$-es sziget magassága 3, míg az ugyanott található $2 \times 2$-es sziget magassága 2 . A jobb oldalon látható $2 \times 2$-es sziget 4-es magasságú. 


\begin{tabular}{||l|l|l|l|l||}
\hline \hline 3 & 2 & 1 & 5 & 5 \\
\hline 2 & 2 & 1 & 5 & 4 \\
\hline
\end{tabular}

4.19. ábra. Szigetek és magasságaik

4.28. Feladat. Adjuk meg a $3 \times 4$-es rács mezőinek magasságértékeit úgy, hogy a rácson a fôsziget mellett még pontosan két sziget legyen, melyek magassága 2 illetve 3 .

Megoldás. Az alábbi ábrán egy lehetséges kitöltés látható. A bal felsô sarok $2 \times 2$-es szigetének magassága 2, míg a jobb alsó sarokban található $2 \times 1$-es sziget magassága 3 .

\begin{tabular}{||l|l|l|l|}
\hline 3 & 3 & 1 & 1 \\
\hline 3 & 2 & 1 & 3 \\
\hline \hline 1 & 1 & 1 & 3 \\
\hline
\end{tabular}

4.20. ábra. 2 illetve 3 magas szigetek

A fenti, szigetrendszerek minimális megadási módjára vonatkozó észrevétel annyira fontos, hogy akár külön fogalmat is bevezethetünk rá. Ezt láthatjuk a következókben.

4.29. Definíció. Legyen adott egy rács, s rajta egy szigetrendszer. Ha a rács minden mezőjének magassága az a pozitív egész szám, ahány szigetnek az adott mezó része, akkor a szigetrendszer ezen megadási módját a szigetrendszer kanonikus reprezentációjának nevezzük.

4.30. Megjegyzés. A fentiek alapján nyilvánvaló, hogy a kanonikus alakban minden mezô magassága a lehetô legkisebb olyan szám, amellyel az adott szigetrendszer előállítható, így akár minimális reprezentációnak is nevezhetnénk.

Azt persze, hogy miért fontos a szigetrendszerek ily módon történô megadása, szintén feldolgozhatjuk feladatok formájában is. A következô két feladat erre mutat példát.

4.31. Feladat. Mi adja a minimális magasságok mellett, a szigetrendszerek kanonikus reprezentációjának jelentôségét? 
Megoldás. A szigetrendszerek ezen megadása már egyértelmú.

4.32. Feladat. Melyik az a magasságérték, amely biztosan megjelenik egy szigetrendszer kanonikus reprezentációjában?

Megoldás. Bármely szigetrendszer kanonikus reprezentánsában biztosan megjelenik egy 1 magasságú mezô. Könnyen látható ugyanis, hogy ha ilyen mezônk nincs, akkor minden magasság csökkenthetô egyesével (a szigetek számának megváltoztatása nélkül) addig, amíg 1 magasságú mezônk nem lesz. Ezek azok a mezók, melyek csak a fôszigetnek részei.

A fogalom megszilárdulását itt is segíthetjük azt különbözô irányból megvilágító feladatokkal. Az alábbiakban erre mutatunk egy példát.

4.33. Feladat. Adjuk meg az alábbi ábrákon látható szigetrendszerek kanonikus reprezentánsát.

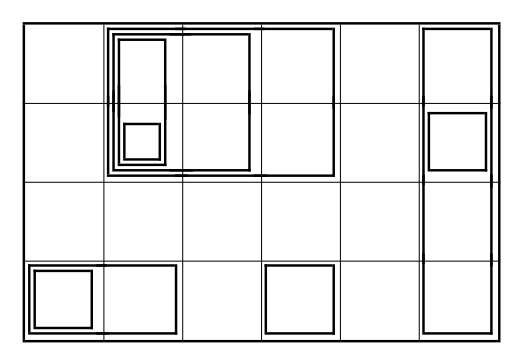

(a)

\begin{tabular}{|l|l|l|l|l|l|}
\hline 2 & 2 & 1 & 3 & 2 & 2 \\
\hline 2 & 3 & 1 & 3 & 2 & 2 \\
\hline 3 & 3 & 1 & 3 & 4 & 4 \\
\hline 1 & 1 & 1 & 3 & 5 & 6 \\
\hline
\end{tabular}

(b)

4.21. ábra. Keressük a kanonikus reprezentánst!

Megoldás. A megoldásokat az alábbi ábrán láthatjuk.

\begin{tabular}{|c||c|c|c|c|c||}
\hline 1 & 4 & 3 & 2 & 1 & 2 \\
\hline 1 & 5 & 3 & 2 & 1 & 3 \\
\hline 1 & 1 & 1 & 1 & 1 & 2 \\
\hline \hline 3 & 2 & 1 & 2 & 1 & 2 \\
\hline \hline
\end{tabular}

(a)

\begin{tabular}{||l|l|l|l|l|l||}
\hline 2 & 2 & 1 & 2 & 2 & 2 \\
\hline 2 & 2 & 1 & 2 & 2 & 2 \\
\hline 2 & 2 & 1 & 2 & 3 & 3 \\
\hline 1 & 1 & 1 & 2 & 4 & 5 \\
\cline { 4 - 6 } & & &
\end{tabular}

(b)

4.22. ábra. Szigetek kanonikus reprezentációja 


\subsubsection{Ismerkedés a korlátos magasságú szigetekkel}

A szigetek keresésében a következô fokozatot a korlátozott magassággal rendelkezô szigetek vizsgálata jelentheti. Itt a magasságok korlátozásával érjük el, hogy feladatainknak csak véges sok megoldása legyen. A korlátos magasságokkal dolgozó eset vizsgálata a kanonikus reprezentáció bevezetése után már természetes folytatása eddigi vizsgálatainknak.

4.34. Feladat. Adjuk meg a mezók magasságértékeit úgy, hogy pontosan a jelölt téglalapok legyenek szigetek, ha a felhasználható maximális magasság $h=1$ !

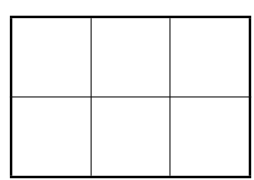

(a)

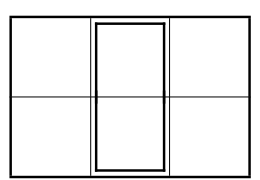

(b)

4.23. ábra. Adjuk meg a magasságokat!

Megoldás. Ha a maximális magasság $h=1$, akkor ez azt jelenti, hogy minden mező magassága 1. Ekkor azonban csak egy szigetünk lehet, a teljes rács, vagyis a fôsziget. Így egy megoldás van a 4.23(a) ábrához, és nincs megoldás a 4.23(b) ábrához kapcsolódóan.

\begin{tabular}{|l|l|l|}
\hline 1 & 1 & 1 \\
\hline 1 & 1 & 1 \\
\hline
\end{tabular}

4.24. ábra. Megoldás, ha a magasság legfeljebb 1

4.35. Feladat. Adjuk meg a mezôk magasságértékeit úgy, hogy pontosan a jelölt téglalapok legyenek szigetek, ha a felhasználható maximális magasság $h=2$ !

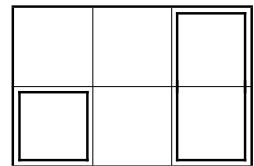

(a)

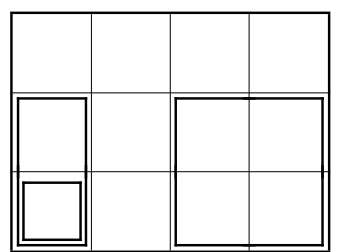

(b)

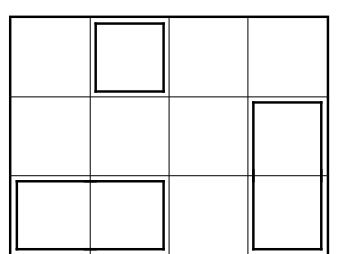

(c)

4.25. ábra. Adjuk meg a magasságokat! 
Megoldás. Hamar megláthatjuk, hogy nem található megoldás a 4.25(b) ábrához. A bal alsó sarok cellája ugyanis három különböző szigetnek is mezóje, így az ô magassága legalább 3 kellene, hogy legyen. A többi feladathoz az alábbiakban mutatunk egy-egy megoldást. Ezeknek a feladatoknak más megoldása nincs is.

\begin{tabular}{||c|c|c||}
\hline 1 & 1 & 2 \\
\hline 2 & 1 & 2 \\
\hline
\end{tabular}

(a) Megoldás 4.26(a)

\begin{tabular}{|l|l|l|l|}
\hline 1 & 2 & 1 & 1 \\
\hline 1 & 1 & 1 & 2 \\
\hline 2 & 2 & 1 & 2 \\
\hline
\end{tabular}

(b) Megoldás 4.26(c)

4.26. ábra. Megoldások, ha a magasság legfeljebb 2

4.36. Megjegyzés. A 4.25(b) ábrához kapcsolódó ellentmondások, illetve maga a nem létező megoldás is fontos szerepet játszik a szigetfogalom megszilárdulásában. A példák mellett megfelelố szerephez kell engednünk jutni az ellenpéldákat is. Különösen fontos, hogy különböző okokból nem múködô példákat, ellenpéldákat mutassunk a fontos tulajdonságok lehetô legtöbb oldalról való kiemelése céljából. Most például megállapíthattuk, hogy ha a megengedett maximális szigetmagasság $h$, akkor a fôszigeten belül legfeljebb $h-1$ szinten egymásba ágyazott szigetek állhatnak. Ez persze szoros kapcsolatban van a kanonikus reprezentáció bevezetése kapcsán tapasztaltakkal.

Ezek után sikerrel próbálkozhatunk összetettebb feladatok megoldásával is. Erre mutat példát a következő feladat.

4.37. Feladat. Adjuk meg a mezők magasságértékeit úgy, hogy pontosan a jelölt téglalapok legyenek szigetek, ha a felhasználható maximális magasság $h=4$ !

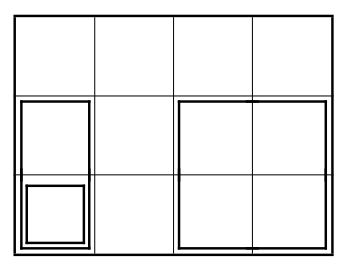

(a)

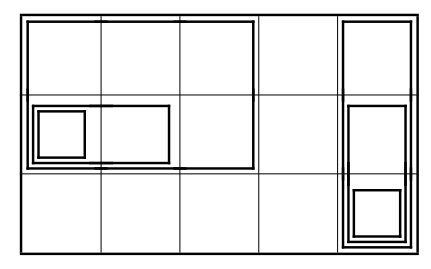

(b)

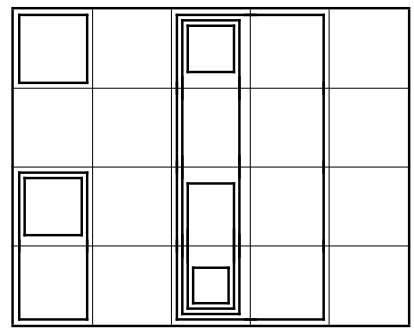

(c)

4.27. ábra. Adjuk meg a magasságokat! 
Megoldás. Az elôzőek alapján könnyen megállapítható, hogy a 4.27(c) ábrához nincs megoldás. A többi feladat (kanonikus) megoldása az alábbiakban látható. A 4.37 (b) feladatnak nincs is más megoldása, míg a 4.37 (a) feladat esetében a kanonikus mellett több más megoldás is létezik.

\begin{tabular}{|c|c|c|c|}
\hline 1 & 1 & 1 & 1 \\
\hline 2 & 1 & 2 & 2 \\
\hline 3 & 1 & 2 & 2 \\
\hline \hline
\end{tabular}

(a)

\begin{tabular}{||c|c|c|c|c||}
\hline \hline 2 & 2 & 2 & 1 & 2 \\
\hline 4 & 3 & 2 & 1 & 3 \\
\hline 1 & 1 & 1 & 1 & 4 \\
\hline \hline
\end{tabular}

(b)

4.28. ábra. Megoldások, ha a magasság legfeljebb 4

A továbbiakban a szigetkeresés problémájának egy másik lehetséges inverzével foglalkozunk.

4.38. Megjegyzés. Fontos módszertani eszköz az ellenpéldák mellett a hibás bizonyítások, rossz megoldások bemutatása. Serkentik ugyanis a kételkedés igényét, valamint a kritikus gondolkodás motorjává is válhatnak, így segítségünkre lehetnek meglévô fogalmaink magasabb szintre történő emelésében is. A következőkben (4.39. feladat 4.42. feladat) erre is példát mutatunk.

4.39. Feladat. Adjuk meg a magasságokat úgy, hogy csak egyetlen sziget legyen a $2 \times 3$-as rácson!

Próbálkozás. Egyetlen szigetünk mindig van, a fôsziget. Ha nincs másik sziget, az csak úgy lehetséges, ha minden mező magassága azonos, például 1.

4.40. Feladat. Mi a véleményünk az elôzô próbálkozásról? Elfogadjuk azt megoldásnak?

Megoldás. Nem. A megoldás hibás. A következő ábra egy ellenpéldát mutat.

\begin{tabular}{|l|l|l|}
\hline 3 & 3 & 2 \\
\hline 3 & 2 & 2 \\
\hline
\end{tabular}

4.29. ábra. Egyenetlen talaj, csak a fôszigettel

Az elôzô feladat egyfajta általánosításaként tekintsük a következő feladatot, s ennek kapcsán a sziget fogalmának további elmélyítését szolgáló, valamint a példák és ellenpéldák szerepét, illetve az igazság monoton növelésének módját jól reprezentáló, hibás és helyes megoldási lehetôségeket. 
4.41. Feladat. Adjuk meg a magasságokat úgy, hogy 2 sziget legyen a $2 \times 3$-as rácson!

Megoldás. Egy lehetséges megoldást mutat az alábbi ábra.

\begin{tabular}{|l|l|l|}
\hline 2 & 1 & 1 \\
\hline 2 & 1 & 1 \\
\hline
\end{tabular}

4.30. ábra. 2 sziget a $2 \times 3$-as rácson

A fenti egy tipikus megoldás. Annak megismerése, hogy nem csak ilyen típusú megoldás (tehát amikor a szigeteken kívül a talaj egyenletes) létezik, fontos a továbbiak szempontjából. Ehhez segít hozzá a következő feladat.

4.42. Feladat. (Próbálkozás az általánosításra.) Igaz-e a 4.41. feladat következô általánosítása? Ha magasságokat kell megadnunk úgy, hogy az $m \times n$-es rácson két szigetünk legyen, akkor, mivel az adott rács, a fősziget mindig sziget, egyetlen lehetôségünk van, mégpedig az, ha egy tetszôleges belsố téglalap alakú tartomány minden mezőjének magasságát $h$-nak $(h>1)$, az összes többi mező magasságát pedig azonos, $h$-nál kisebb, pozitív egésznek választjuk.

Megoldás. Nem, és az indoklás a 4.39. feladat megoldásának vizsgálata során tapasztaltak alapján könnyen meglelhetô. Egy ellenpéldát mutat a következô ábra.

\begin{tabular}{|l|l|l|}
\hline 1 & 2 & 2 \\
\hline 3 & 1 & 2 \\
\hline
\end{tabular}

4.31. ábra. Ellenpélda a 4.42. feladat állítására

4.43. Megjegyzés. Amennyiben szigetrendszerünket kanonikus alakban kell megadni, akkor viszont a $h=2$ kiegészítéssel már igaz lesz a 4.42. feladat állítása.

A következô feladattal lezárjuk ezt a rövid szakaszt, melynek keretében a fentiekben részletezett módszertani elvek bemutatása mellett, eljutunk egy kis rácson a minimális szigetszámtól a létrehozható maximális szigetszámig. Azt, hogy több szigetet tényleg nem lehet létrehozni, a késôbbiekben (4.5. fejezet) be is fogjuk bizonyítani. Maximálisan sok sziget létrehozása már viszonylag kis rácsok esetén is nehéz feladat. Jelenleg a cél nem más, mint a maximum elérése - annak említése nélkül, hogy ez az elérhetô maximum - ezzel is segítvén a szigetek maximális számára vonatkozó sejtés kialakulását. 
4.44. Feladat. Adjuk meg a magasságokat úgy, hogy 5 sziget legyen a $2 \times 3$-as rácson!

Megoldás. Egy lehetséges megoldást mutat az alábbi ábra.

\begin{tabular}{|l|l|l|}
\hline 2 & 1 & 2 \\
\hline 3 & 1 & 3 \\
\hline
\end{tabular}

4.32. ábra. 5 sziget a $2 \times 3$-as rácson

4.45. Megjegyzés. A fentiekben megadott hibás és helyes próbálkozásokban illetve megoldásokban csak a rácsokat adtuk meg, azokban a szigeteket nem jelöltük. Ezen a szinten ez már megtehetô, s kívánatos is, ezzel is segítvén a fogalom absztrahálódását.

A következőkben tovább folytatjuk szigeteink vizsgálatát viszonylag kis méretû $(2 \times 3$-as $)$ rácsunk esetében, ám ezúttal korlátozott magasságfüggvény mellett. Célunk a korlátos eset további vizsgálatának megalapozása, valamint annak érzékeltetése, hogy a nagymértékú hasonlóság ellenére itt egy teljesen más problémáról van szó. Ezt könnyebben elérhetjük, ha a fenti problémák korlátos esetre vonatkozó analogonjait dolgozzuk fel.

4.46. Feladat. Adjuk meg a magasságokat úgy, hogy 1 sziget legyen a $2 \times 3$-es rácson, ha a megengedett maximális szigetmagasság $h=1$ !

Megoldás. A megoldás egyszerú. Egyetlen lehetôségünk, hogy rácsunkat egyesekkel töltjük fel, s ekkor valóban csak egy szigetünk van, a fôsziget.

4.47. Feladat. Adjuk meg a magasságokat úgy, hogy 2 sziget legyen a $2 \times 3$-as rácson, ha a megengedett maximális szigetmagasság $h=1$ !

Megoldás. Nincs megoldás, mivel a rácsunkat egyesekkel feltöltve csak egyetlen sziget keletkezhet.

A következő feladatban eljutunk a $2 \times 3$-as rácson $h=2$ magassággal elérhető maximális szigetszámhoz. Az, hogy ennél több szigetünk jelen feltételek mellett nem lehet, egyelőre még csak sejtés. Ezt azonban késóbb be is fogjuk bizonyítani (4.6.4. fejezet). Már ez a sejtés szintú észrevétel is elég azonban ahhoz, hogy jelen probléma kapcsán általánosítást fogalmazzunk meg (4.49. feladat), illetve, hogy a korábban, a nem korlátos esetben tapasztaltaktól (4.44. feladat) eltérő eredményünk alapján érzékeltessük, hogy a korlátos esetben egy teljesen más megközelítést igénylő problémával állunk szemben. 
4.48. Feladat. Adjuk meg a magasságokat úgy, hogy 3 sziget legyen a $2 \times 3$-as rácson, ha a megengedett maximális szigetmagasság $h=2$ !

Megoldás. Az alábbi ábra egy lehetséges megoldást mutat.

\begin{tabular}{|l|l|l|}
\hline 2 & 1 & 2 \\
\hline 1 & 1 & 1 \\
\hline
\end{tabular}

4.33. ábra. 3 sziget a $2 \times 3$-as rácson

4.49. Feladat. Fogalmazzunk meg általános észrevételt a 4.48. feladat alapján az $m \times n$-es rács legfeljebb 2 magas szigeteinek számára vonatkozóan!

Megoldás. Ha legfeljebb 2 magas szigeteket kell elhelyeznünk az $m \times n$-es rácson, akkor leghatékonyabban az 1 magas mezók által határolt egy területú 2 magas mezók alkotnak szigetet. Belólük az $m \times n$-es rácson legfeljebb $\left\lceil\frac{n}{2}\right\rceil \cdot\left\lceil\frac{m}{2}\right\rceil$ van, s a fôszigetet is számolva a szigetek maximális számára $\left\lceil\frac{n}{2}\right\rceil \cdot\left\lceil\frac{m}{2}\right\rceil+1$ adódik, ahol $\lceil x\rceil$ az $x$ valós szám felsố egészrészét jelöli. Az alábbi ábra egy lehetséges megoldást mutat a $6 \times 7$-es esetben.

\begin{tabular}{|l|l|l|l|l|l|l|}
\hline 2 & 1 & 2 & 1 & 2 & 1 & 2 \\
\hline 1 & 1 & 1 & 1 & 1 & 1 & 1 \\
\hline 2 & 1 & 2 & 1 & 2 & 1 & 2 \\
\hline 1 & 1 & 1 & 1 & 1 & 1 & 1 \\
\hline 2 & 1 & 2 & 1 & 2 & 1 & 2 \\
\hline 1 & 1 & 1 & 1 & 1 & 1 & 1 \\
\hline
\end{tabular}

4.34. ábra. Szigetek a $6 \times 7$-es rácson, ha $h=2$ 


\subsubsection{A sziget fogalmának kialakulását segítő Mathematica animáció}

\section{Bevezetés}

Ebben a fejezetben bemutatunk egy, többek között a sziget fogalmának kialakításában és megszilárdításában is jól használható interaktív Mathematica animációt.

A Mathematica 6. verziótól kezdődően a Mathematica programcsomagban lehetôségünk van az órai munkát is segítô alkalmazások egyszerú létrehozására. A logikus felépítésú, egyszerû nyelv használatával könnyedén hozhatunk létre felhasználóbarát, látványos animációkat, interaktív játékokat. Miközben a teljes forrás rejtve marad a felhasználók elől, elkészített alkalmazásainkat széles körben oszthatjuk meg diákjainkkal, kollegáinkkal. Erre kiváló példa a már korábban említett és használt Wolfram Demonstrations Project [169]. A már elkészült alkalmazások használatához pedig elegendô az ingyenesen elérhetô Mathematica Player [168].

\section{Az alkalmazás bemutatása}

Jelen alkalmazásban a felhasználó (játékos, felfedezô) egy $2 \times 3$-as ráccsal kezdheti meg a játékot.

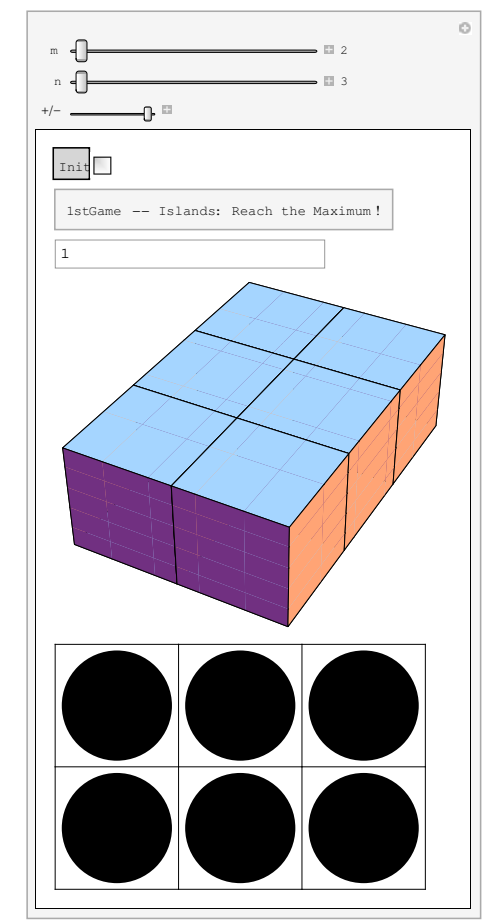

(a)

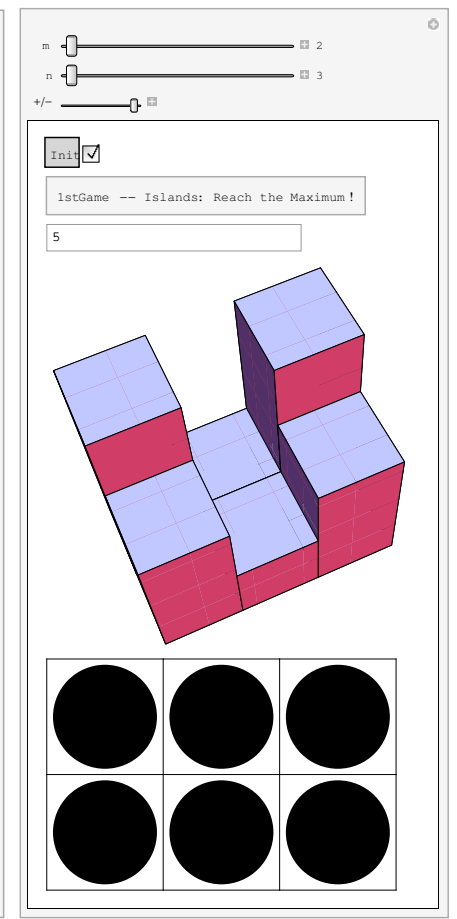

(b)

4.35. ábra. Játék a szigetekkel Mathematicaban 
Kezdetben minden mezố magassága 1. A rács alatt található mezôk segítségével, egy egyszerú kattintással növelhetô a megfelelő mezők magassága. A játékmezô felsô részén található csúszkák segítségével változtatható a tábla mérete, illetve elérhetô, hogy az egyes mezők magasságát ne csak növelni, de csökkenteni is tudjuk. A háromdimenziós ábránk mérete szintén változtatható, sôt tetszóleges mértékben és irányba forgatható is, a kialakuló szigetrendszerre való optimális rálátást segítendő. Egyetlen kattintással lehetôségünk van a táblánk inicializálására, ekkor visszakapjuk az alapállapotot, amelyben minden mezố magassága 1. A csúszkák alatt pedig folyamatosan látható az, hogy éppen aktuálisan hány szigetünk van. Az ilyen és ehhez hasonló alkalmazások természetesen maradéktalanul képesek együttmúködni az interaktív táblákkal is. Így a tanulói felfedezés összekapcsolható az aktív tanulói részvétellel. Kattintgatások helyett a tábla érintésével hozhatunk létre szigeteket.

\section{A játék célja}

A játék célja, hogy maximális számú szigetet kreáljunk az adott rácson, tehát egy maximális szigetrendszert. Ha ezt elértük, egy kis pipa jelenik meg a táblán.

Az alkalmazást valódi céljától függetlenül, a megismerés jelen fázisában is haszonnal forgathatjuk. Segíthetjük vele a szigetfogalom kialakulását, hiszen folyamatosan nyomon követhetô, hogy hány szigetünk van éppen. Így a diákoknak lehetôségük van önállóan felfedezni, hogy mit is tekintünk szigetnek, s mit nem. A szigetrendszerek kreálása során kialakulhatnak sejtések a szigetek elhelyezkedésére, maximális számára, illetve például a felhasználandó maximális magasságokra vonatkozóan is. Ezeket a további tárgyalás során eredményesen hasznosíthatjuk.

A sziget fogalmának egy kevésbé részletes felépítése, illetve a fenti animáció részletes bemutatása megtalálható a szerző [110] cikkében (Attila Máder, Róbert Vajda. Elementary Approaches to the Teaching of the Combinatorial Problem of Rectangular Islands, International Journal of Computers for Mathematical Learning, 15(3), 267-281, 2010.).

\subsubsection{Módszertani összefoglaló}

A fejezetben feladatokon keresztül nyertünk bevezetést a szigetek világába. Kialakítottuk és megszilárdítottuk a rács, a mezô, a sziget, a fôsziget a magasság(függvény), a szigetrendszer, a kanonikus reprezentáció és a sziget magasságának fogalmát. A kitûzött feladatok a következôképp csoportosíthatók:

(a) A sziget fogalmának intuitív megközelítése (4.1.-4.9.).

(b) A sziget matematikai fogalmának kialakítása, absztrahálása (4.10.-4.13.).

(c) Szigetek keresése adott magasságfüggvény mellett (4.15.).

(d) Inverzproblémák a fogalom elmélyítésére (4.17., 4.34.-4.49.). Ezek a következôképp kategorizálhatók: 
- magasságfüggvény keresése adott szigetrendszerhez,

- magasságfüggvény keresése adott szigetszámhoz,

- korlátos magasságfüggvény keresése adott szigetrendszerhez,

- korlátos magasságfüggvény keresése adott szigetszámhoz.

(e) Szigetrendszerek megadása, kanonikus reprezentáció (4.19.-4.33.).

(f) Újabb definíciók, példák, ellenpéldák kreálása, bizonyítások relevanciájának ellenôrzése (4.39.-4.44).

A bemutatott Mathematica alkalmazás segítségével a fentiek játékos formában, aktív tanulói tapasztalatszerzéssel kísérve hajthatók végre. Az alkalmazás segítségével a tanulók kísérletek tucatjait végezhetik, akár közösen órán, akár otthon egyedül. A számítógép segítségével szerzett tapasztalatok segítenek a fogalmak gyors és hatékony kialakításában, elmélyítésében.

Külön felhívjuk a figyelmet a fokozatosságra, mely a felfedeztetés-központú tanítás esetén is fontos. Mindig adjunk elég idôt egy adott fogalom megértéséhez, s ha kell, újabb és újabb példák segítségével alkalmazzuk, mélyítsük, absztraháljuk azt, míg a kívánt szintre el nem jutunk. A bemutatott eszközök felhasználásával tetszőleges számú feladat állítható elő gyorsan és hatékonyan.

A tanulók többféleképp is motiválhatók a munkára, melyet akár egyénileg, akár csoportokban is végezhetnek. Minden csoportnak kioszthatunk például egy-egy rácsot, (magasságfüggvénnyel vagy anélkül), s célul túzhetjük ki a lehetô legtöbb sziget megtalálását, vagy kreálását. A leggyorsabbat, illetve a legjobb eredményt eléróket külön jutalomban részesíthetjük. Egy-egy adott típusú feladat elvégzése után célszerú mindig új csoportokat alakítani, melyekbe ezáltal különbözô képességú, a korábbi feladatokat eltérô hatékonysággal megoldó diákok kerülhetnek. A tipikusan több megoldással rendelkező feladatok jó alapul szolgálhatnak az eredmények és felfedezések közösségi szintú tárgyalásához. A gyerekek feladata lehet az eredmények, felfedezések többiekkel való ismertetése, különbözô eredmények esetén a vélemények ütköztetése, az álláspontok megvédése.

\section{4. $\quad$ Szigetrendszerek szerkezete}

Ebben a fejezetben ismét egy lépést teszünk távlati célunk, a szigetek maximális számának meghatározása felé. A szigetek összeszámlálása során is előnyös, ha valamely stratégia mentén tudjuk azt megejteni. Ehhez nyújt segítséget, ha szigeteinket osztályozzuk. Az osztályozáshoz a korábbi kísérletek során szerzett tapasztalatainkat, intuitív fogalomesíráinkat fogjuk használni [110]. 


\subsubsection{Metszô szigetek}

Az alábbiakban a szigetek kölcsönös helyzetére vonatkozó sejtéseinket emeljük magasabb szintre.

4.50. Feladat. Azt már láttuk, hogy két sziget közül egyik tartalmazhatja a másikat. Láttunk-e példát más módon érintkezô szigetekre?

Megoldás. Nem. Ha ilyen konstrukciót tartalmazó szigetrendszer volt adva, arról megtapasztaltuk, hogy nem is létezik, illetve az ilyen típusú szigetrendszerek létrehozására vonatkozó kísérleteink kudarcba fulladtak (4.17. feladat).

4.51. Feladat. A korábbiak (4.17. feladat, illetve a 4.3.6. fejezet játékának használata) alapján milyen sejtésünk alakult ki a szigetek elhelyezkedésére, kölcsönös helyzetére vonatkozóan?

Megoldás. A vizsgálatok alapján a következő sejtés fogalmazható meg.

4.52. Sejtés. Két különböző szigetnek csak akkor lehet közös mezője, illetve határa, ha egyik tartalmazza a másikat. Azaz két különböző sziget közül az egyik tartalmazza a másikat, vagy a szigetek „messze” vannak egymástól, azaz el tudunk sétálni (úszni) közöttük.

A korábbi, számítógéppel sokszorozott kísérleteink hatására nem csak a fenti sejtés vált kellóképp erôssé, de az igazság monoton növelése során az okok feltárása is lehetôvé vált. Így már maga a bizonyítás is kísérleteinknek köszönhetôen intuitívan megalapozott. Absztrakt leírása ezek után egyszerú.

Bizonyítás. Azt már láthattuk, hogy két sziget közül egyik tartalmazhatja a másikat. Tegyük most fel, hogy van két olyan szigetünk, melyeknek van közös mezője (vagy akár csak határpontja) és egyik sem tartalmazza a másikat.

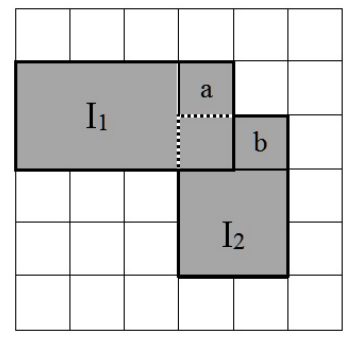

4.36. ábra. Metszô szigetek 
Legyen a két sziget $I_{1}$ és $I_{2}$. Mivel $I_{1}$ sziget, így minden mezôjének magassága nagyobb, mint környezete bármely mezôjének magassága, ezért

$$
a>b
$$

De mivel $I_{2}$ is sziget, ezért ugyanez az ô mezôire is fennáll, vagyis

$$
b>a
$$

Ekkor 4.1 és 4.2 összevetéséból ellentmondásra jutunk.

4.53. Megjegyzés. A fenti bizonyítás abban az esetben is érvényes, ha a két sziget nem metszi egymást, csak közös határpontjuk van.

Tételünknek nem csak a szigetrendszerek szerkezetére vonatkozóan van jelentôsége. Megfordítása segítségével ugyanis egy új definíciót is tudunk adni a sziget fogalmára. A következôkben ezt készítjük elő.

A fentiek segítségével további észrevételek fogalmazhatók meg a szigetrendszerek szerkezetére vonatkozóan. Az egyik ezek közül az, hogy a fenti tulajdonság jellemzi is a szigetrendszereket, vagyis igaz a fenti tétel következô értelemben vett megfordítása.

4.54. Tétel. Tetszôleges, a 4.52. sejtés feltételeinek eleget tevô téglalaphalmaz szigetrendszerré tehetô a magasságok megfelelô megválasztásával.

Bizonyítás. Legyen a rácsunk $m \times n$-es; $m n$-szerinti indukcióval bizonyítunk. Ha $m n=1$, vagy mindösszesen 1 szigetünk van, a fôsziget, készen vagyunk. Legyen $m n>1$, és tegyük fel, hogy az állítás minden kisebb $m n$ esetén igaz. Tekintsük most a maximális téglalapokat. Ezek azok, a fôszigettôl különbözô téglalapok, melyeket valódi módon csak a teljes rács tartalmaz téglalapjaink közül. Ezekre, mint rácsokra az indukciós feltevés miatt igaz az állítás, így meg tudjuk választani a magasságokat úgy, hogy a maximális téglalapok, mint szigetrendszerek eleget tegyenek a feladat feltételének, vagyis azokban csak a jelölt téglalapok legyenek szigetek. Végül töltsük ki a rácsunk még kitöltetlen mezôit olyan magasságértékkel, amely minden eddig felhasználtnál kisebb (ha ilyen nincs, emeljünk meg minden eddigi magasságot eggyel, így az 1 magasság megfelelő lesz), így a maximális téglalapok is szigetté váltak.

A téglalapok fenti elhelyezkedése tehát jellemzi is a szigetrendszereket, így ezáltal megtaláltuk a szigetrendszer egy másik definícióját is. A következô definíció nem használja a magasság fogalmát, viszont a szigetrendszereket a bennük elhelyezkedő szigetek kölcsönös helyzete alapján jellemzi. Távlati célunk, a szigetek maximális számának meghatározása szempontjából ez a kölcsönös helyzet kulcsfontosságú lesz, ezért ezen definíció szerepeltetése jelen helyen különösen indokolt.

4.55. Definíció. Legyen adott egy $m \times n$-es rács. Ezen rács téglalapjainak egy $\mathcal{R}$ halmazát szigetrendszernek nevezzük, ha bármely $R_{1}, R_{2} \in \mathcal{R}, R_{1} \neq R_{2}$ esetén $R_{1} \subset$ $R_{2}$, vagy $R_{2} \subset R_{1}$ vagy $R_{1}$ egyetlen cellája sem szomszédos $R_{2}$ egyetlen cellájával sem. 
A szigetrendszerek szerkezetének feltérképezése során fontos lépés a szigetek osztályozása. Erre mutatunk példát a következô fejezetben.

\subsubsection{Maximális és minimális szigetek}

Korábbi, konkrét kísérleteinkben speciális szigetekkel is találkoztunk. Ebben a pontban ezek rendszerbe foglalására mutatunk lehetôséget, a tanulói felfedezést, önálló fogalomalkotást továbbra is szem elôtt tartva. A jelen fejezetben megismert minimális és maximális szigetek fontos szerepet játszanak majd a késóbbiekben, a szigetek maximális számának meghatározása során, megismerésük a szigetrendszerek szerkezetének részletesebb feltérképezése mellett ezért is fontos.

4.56. Feladat. Mikor hív(hat)unk egy szigetet maximálisnak, illetve minimálisnak?

Megoldás. Mivel a fősziget bármely szigetrendszer esetén mindig jelen van, és már külön neve is van, nincs értelme ôt maximálisnak (is) nevezni. Természetes útja a fogalomalkotásnak, ha ezek után közvetlenül a fôsziget „alatt” elhelyezkedő szigeteket tekintjük. Nevezzük tehát maximális szigetnek azokat a fôszigettől különböző szigeteket, melyeket a fôsziget kivételével egyetlen másik sziget sem tartalmaz valódi módon. A minimális sziget fogalmának megalkotásakor már egyszerúbb dolgunk van. Legyenek a minimális szigetek azok a szigetek, amelyek nem tartalmaznak (valódi módon) egyetlen másik szigetet sem. Az alábbi ábrán a minimális illetve maximális szigeteket vastag keretezéssel jelöltük.

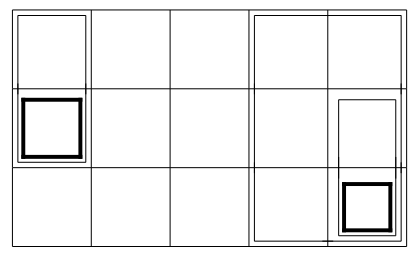

(a) Minimális szigetek

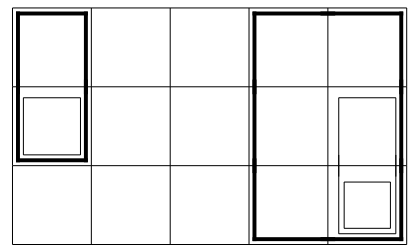

(b) Maximális szigetek

4.37. ábra. Minimális és maximális szigetek

4.57. Megjegyzés. A fenti mellett természetesen számos más, értelmes definíció is adható a maximális illetve a minimális sziget fogalmára. Ezen a ponton mindenképp érdemes körbejárni a különbözô tanulói megközelítéseket, megvizsgálva azok elônyeit és hátrányait. Mi a továbbiakban a fenti értelmezéssel élünk, mert távlati célunk, a szigetek maximális számának meghatározása szempontjából ez az egyik legcélravezetôbb.

A következô feladatok célja a minimális, illetve a maximális sziget fogalmának elmélyítése, absztrahálása. Használhatjuk itt is a 4.3.6. fejezet játékát, melyben folyamatosan újragenerálható szigetrendszerek tucatjain végezhetjük el a minimális és 
maximális szigetek vizsgálatát, ezzel is segítvén az önálló tanulói felfedezéseken alapuló fogalomalkotást.

4.58. Feladat. Hány minimális, illetve maximális sziget van az alábbi ábrán?

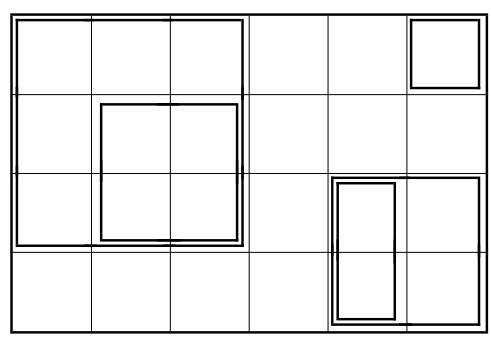

4.38. ábra. Minimális és maximális szigetek

Megoldás. Három minimális és három maximális szigetünk van. Ezeket az alábbi ábrán vastag keretezéssel jelöltük is.

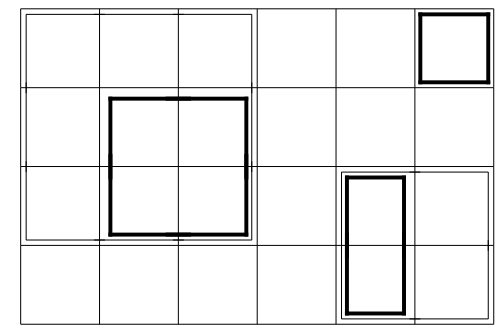

(a) Minimális szigetek

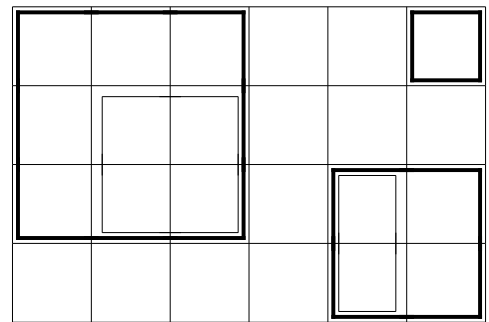

(b) Maximális szigetek

4.39. ábra. Minimális és maximális szigetek

4.59. Feladat. Lehet-e egy sziget egyszerre minimális és maximális?

Megoldás. Igen. Az elôzô (4.39.) ábra egy példát mutat. A jobb felsô sarokban található $1 \times 1$-es sziget minimális és maximális is.

4.60. Feladat. Lehet-e egyszerre minden sziget minimális és maximális?

Megoldás. Nem, mivel a fôsziget mindig sziget, de sohasem maximális.

4.61. Feladat. Lehet-e, hogy nincs minimális szigetünk? 
Megoldás. Nem. Ha van legalább egy szigetünk (és egy mindig van, a fősziget), akkor ezen belül keressünk egy szigetet. Ha nem találtunk, akkor ez azt jelenti, hogy jelen szigetünk minimális. Ha találtunk újabb szigetet, ismételjük meg rá iménti eljárásunkat. Ez az eljárás véges sok lépésben véget ér, s minimális szigetet szolgáltat. Egy más megközelítéssel élve a maximális magasságú sziget biztosan minimális.

4.62. Feladat. Lehet-e, hogy nincs maximális szigetünk?

Megoldás. Igen. Mivel a fôsziget nem maximális, ezért ha csak a fôsziget sziget, egyetlen szigetünk van, amely nem maximális. (Erre mutatott példát korábban többek között a 4.24 ábra és a 4.29 ábra.) Viszont minden más esetben van maximális szigetünk, ugyanis a fốsziget által valódi módon tartalmazott szigetek közül a minimális magasságú maximális. Kanonikus reprezentáció esetén ezek a 2 magasságú szigetek.

\subsubsection{Szigetek és gráfok}

A szigetrendszerek szerkezetének teljesebb feltérképezése céljából ebben a fejezetben egy mélyebb matematikai eszköz, a gráf fogalmát fogjuk használni. Bevezetjük tehát a szigetrendszer gráfjának fogalmát, amely komoly szerepet játszik a szigetrendszer fogalmának absztrahálásában, illetve távlati célunk, a szigetek maximális számának meghatározásában is.

A következő feladatban intuitív módon jelenik meg a szigetrendszer gráfja.

4.63. Feladat. Fogalmazzunk meg észrevételt az alábbi ábra alapján a szigetrendszerek és a gráfok kapcsolatáról.

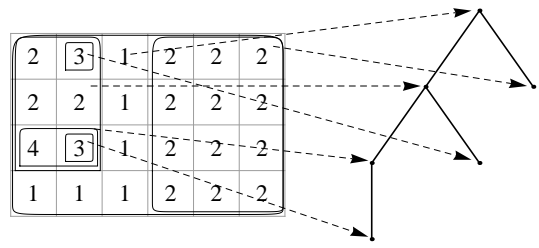

4.40. ábra. Szigetek és gráfok

Megoldás. Láthatóan minden szigetrendszerhez rendelhetünk egy, a tartalmazásra épülő gráfot, a szigetrendszer gráfját.

A fent bevezetett gráf és a hozzá tartozó szigetrendszer kapcsolatának további vizsgálatából újabb megállapításokhoz juthatunk a szigetrendszerek szerkezetét illetôen. Ez ölt testet a következő tétel formájában. 
4.64. Tétel. Tetszóleges rács szigetei a tartalmazásra nézve részbenrendezett halmazt alkotnak.

Bizonyítás. Minden sziget tartalmazza (nem valódi módon) önmagát, így bármely $I$ szigetre $I \subseteq I$, vagyis a tartalmazás mint reláció reflexív. Bármely $I_{1}, I_{2}$ sziget esetén, ha $I_{1} \subseteq I_{2}$ és $I_{2} \subseteq I_{1}$, akkor $I_{1}=I_{2}$, a reláció antiszimmetrikus. Bármely $I_{1}, I_{2}, I_{3}$ sziget esetén, ha $I_{1} \subseteq I_{2}$ és $I_{2} \subseteq I_{3}$, akkor $I_{1} \subseteq I_{3}$, azaz relációnk tranzitív. Ezzel beláttuk, hogy szigeteink a tartalmazásra nézve részbenrendezett halmazt alkotnak.

A fenti, a szigetrendszerek szerkezetére vonatkozó megállapítás tükrében a szigetrendszerünk gráfja is más értelmet nyer.

4.65. Feladat. Hogyan interpretálható a fentiek alapján 4.63. feladat gráfja?

Megoldás. A gráf szigetrendszerünk Hasse-diagramja.

A fentiekben példát láthattunk arra, hogyan segítik a kísérletek a fogalmak ciklikus absztrahálását. Új fogalmaink segítségével megadhatjuk a szigetrendszer egy új modelljét is.

4.66. Feladat. Tekintsünk egy szigetrendszert. Adjunk egy, a szigetrendszert (jól) leíró modellt, melyben a szigetek kölcsönös helyzetük alapján kerülnek jellemzésre!

Megoldás. Egy lehetséges modell a következő. Rendeljünk szigetrendszerünkhöz egy irányított gráfot. A gráf csúcsainak feleltessük meg szigeteinket. A kisebb szigeteket a gráf alacsonyabb szintjeire helyezzük. Az $I_{1}$ csúcsból pontosan akkor indul él az $I_{2}$ csúcsba, ha a hozzájuk rendelt $I_{1}$ sziget közvetlenül tartalmazza az $I_{2}$ szigetet, azaz $I_{2} \subset I_{1}$, és nem létezik olyan $I_{3}$ sziget, melyre $I_{2} \subset I_{3} \subset I_{1}$. Ekkor azt mondjuk, $I_{1}$ fedi $I_{2}$-t, jelölésben: $I_{2} \prec I_{1}$.

4.67. Megjegyzés. A továbbiakban a gráfon nem jelöljük az élek irányát, azok a szemléletnek megfelelően „fentrôl lefelé” mutatnak. Szintén nincs jelentôsége az élek hosszának, vagyis annak, mely csúcs a gráfnak melyik szintjén helyezkedik el. A jobb áttekinthetőség kedvéért azonban célszerú minden csúcsot a neki megfeleltetett sziget tartalmazási relációban elfoglalt helyének megfelelő mélységbe helyezni. Ez azt jelenti, hogy ha szigetrendszerünk kanonikus alakban adott, akkor minden szigetnek megfeleltetett csúcsot az adott sziget magasságának megfelelő mélységi szintre helyezünk a gráfban. Mivel fố célunk, a szigetek maximális számának meghatározása szempontjából feltehető, hogy minimális magasságú szigetekkel dolgozunk, ezért a továbbiakban a legtöbb esetben kanonikus reprezentációt fogunk használni.

A következő feladatok célja a szigetrendszer gráfjának mélyebb megismerése, a fogalom absztrahálása, illetve a gráf meghatározó tulajdonságainak felfedeztetése, valamint a szigetek és a gráfok kapcsolatának mélyebb feltárása. 
4.68. Feladat. Rajzoljuk fel az alábbi ábrákon látható szigetrendszerek gráfját!

\begin{tabular}{|l|l|l|}
\hline 3 & 1 & 3 \\
\hline 2 & 1 & 2 \\
\hline 3 & 1 & 3 \\
\hline
\end{tabular}

(a)

\begin{tabular}{|l|l|l|l|}
\hline 3 & 2 & 1 & 3 \\
\hline 2 & 2 & 1 & 2 \\
\hline 4 & 3 & 1 & 1 \\
\hline
\end{tabular}

(c)

\begin{tabular}{|l|l|l|l|l|}
\hline 5 & 4 & 3 & 2 & 1 \\
\hline
\end{tabular}

(b)

\begin{tabular}{|l|l|l|l|l|}
\hline 1 & 2 & 1 & 2 & 1 \\
\hline 1 & 1 & 1 & 1 & 1 \\
\hline 2 & 1 & 3 & 2 & 3 \\
\hline
\end{tabular}

(d)

4.41. ábra. Rajzoljuk fel a gráfokat!

Megoldás. A következô ábra egy-egy lehetséges, a szemléletünknek leginkább megfelelô, azaz a 4.67. megjegyzésben részletezett módon megadott megoldást mutat.

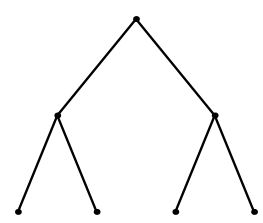

(a)

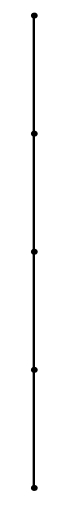

(b)

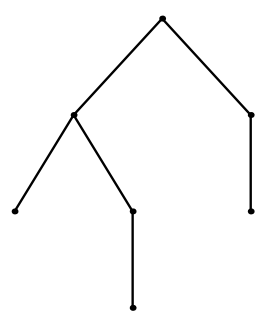

(c)

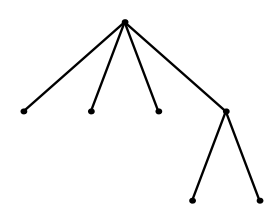

(d)

4.42. ábra. Szigetrendszereink gráfjai

A jobb megértés érdekében itt is egy inverz feladattal folytatjuk a feldolgozást. 
4.69. Feladat. Adjunk meg az alábbi gráfokkal reprezentált szigetrendszereket!

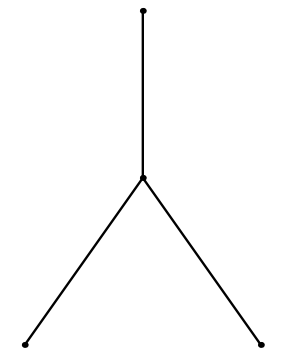

(b)

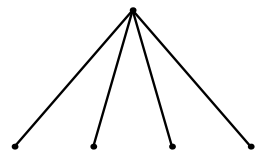

(c)

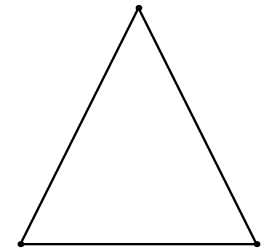

(d)

(a)

\begin{tabular}{|l|l|}
\hline 1 & 1 \\
\hline 1 & 1 \\
\hline
\end{tabular}

(a)

\begin{tabular}{|l||c|c||c|}
\hline 1 & 2 & 2 & 3 \\
\hline 1 & 3 & 2 & 3 \\
\hline 1 & 3 & 2 & 3 \\
\hline
\end{tabular}

(b)

\begin{tabular}{|c|c|c|}
\hline 2 & 1 & 2 \\
\hline 1 & 1 & 1 \\
\hline 2 & 1 & 2 \\
\hline
\end{tabular}

(c)

4.44. ábra. Gráfjaink szigetrendszerei

A példák és ellenpéldák gondolatébresztô hatásának köszönhetôen a fentiek alapján felfedezhetjük a szigetrendszerek gráfjának legfontosabb tulajdonságait.

4.70. Feladat. A fenti kísérletek alapján a szigetrendszerek gráfjának mely tulajdonságai fedezhetôk fel?

Megoldás. Gráfjaink minden esetben körmentes, összefüggő gráfok, vagyis fák. A fősziget a fa gyökere. A gráf biztosan összefüggő, hiszen a fősziget minden szigetet tartalmaz. Legyen a gráfhoz tartozó rácsunk $m \times n$-es. A körmentességet $m n$-szerinti 
indukcióval bizonyítjuk. Ha $m n=1$ vagy mindösszesen 1 szigetünk van, a fősziget, akkor készen vagyunk. Legyen $m n>1$, és tegyük fel, hogy az állítás minden kisebb $m n$ esetén igaz. Tekintsük most a maximális szigeteket. Ezekre, mint rácsokra az indukciós feltevés miatt igaz az állítás, azaz az általuk meghatározott szigetrendszerek gráfjai diszjunkt fák. Ezen fák gyökereit a főszigetnek megfeleltetett csúcs fedi, így a teljes szigetrendszer gráfja is fa.

Azt már láthattuk, hogy a fôszigetnek megfeleltetett csúcs a szigetrendszer fájának gyökere. A következô néhány feladat célja, a korábban megismert további speciális szigetek és a gráf kitüntetett csúcsai közötti kapcsolat felfedeztetése.

4.71. Feladat. Mely szigetek tartoznak a gráfunk leveleihez?

Megoldás. A minimális szigetek.

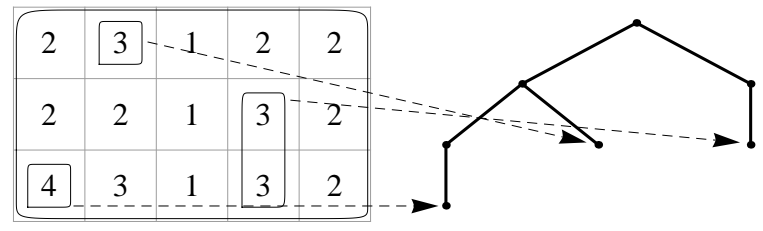

4.45. ábra. A minimális szigetek a levelek

4.72. Feladat. Mely szigeteket feleltettük meg a gyökér által fedett csúcsoknak?

Megoldás. A gyökér fiainak megfeleltetett szigetek a maximális szigetek.

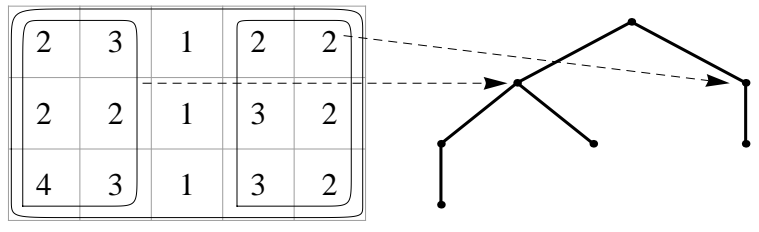

4.46. ábra. A maximális szigetek a gyökér fiai

A szigetek, illetve szigetrendszerek és a hozzájuk tartozó rácsok, magasságfüggvények kapcsolatának felfedeztetésének mintájára (4.15.-4.49.), jelen pontban is számos 
feladatot tûzhetünk ki a gráfok és a szigetrendszerekhez tartozó rácsok vizsgálatára. Vizsgálhatjuk például a rács méretének, vagy a magasságfüggvény értékkészletének kapcsolatát a gráfokkal. A számos lehetôség közül egyre mutatunk példát a következôkben. Itt a feldolgozásba jobban illeszkedően, a szigetek számának és a gráfoknak a kapcsolatát vizsgáljuk.

4.73. Feladat. Adjunk meg egy olyan szigetrendszert a $3 \times 4$-es rácson, amely gráfjának pontosan
(a) 1 ,
(b) 2 ,
(c) 4 ,
(d) 8 ,
(e) 9 csúcsa van.

Megoldás. Az alábbi ábra egy-egy lehetséges megoldást mutat.

\begin{tabular}{|l|l|l|l|}
\hline 1 & 1 & 1 & 1 \\
\hline 1 & 1 & 1 & 1 \\
\hline 1 & 1 & 1 & 1 \\
\hline
\end{tabular}

(a)

\begin{tabular}{|l|l|l|l|}
\hline 2 & 2 & 1 & 2 \\
\hline 2 & 3 & 1 & 2 \\
\hline 2 & 2 & 1 & 2 \\
\hline
\end{tabular}

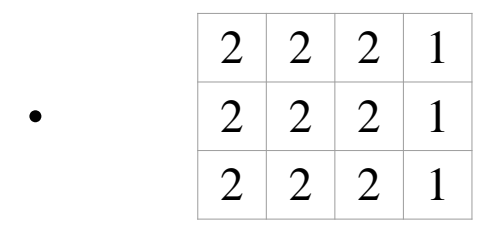

(b)

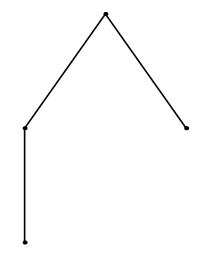

(c)

\begin{tabular}{|l|l|l|l|}
\hline 3 & 1 & 3 & 3 \\
\hline 2 & 1 & 2 & 2 \\
\hline 3 & 1 & 4 & 3 \\
\hline
\end{tabular}

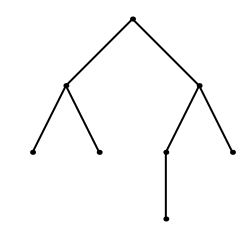

(d)

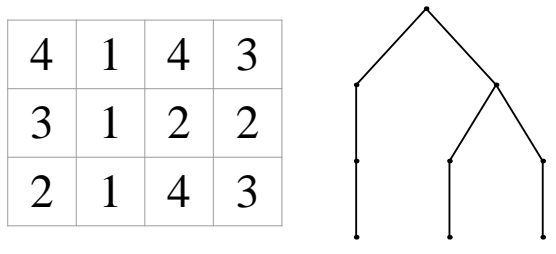

(e)

4.47. ábra. Gráfok és szigetek 


\subsubsection{A szigetrendszerek szerkezetének felfedezését segítő Mathematica animáció}

A 4.3.6. fejezet technikai észrevételeinek tükrében tekintsük a következô demonstrációt.

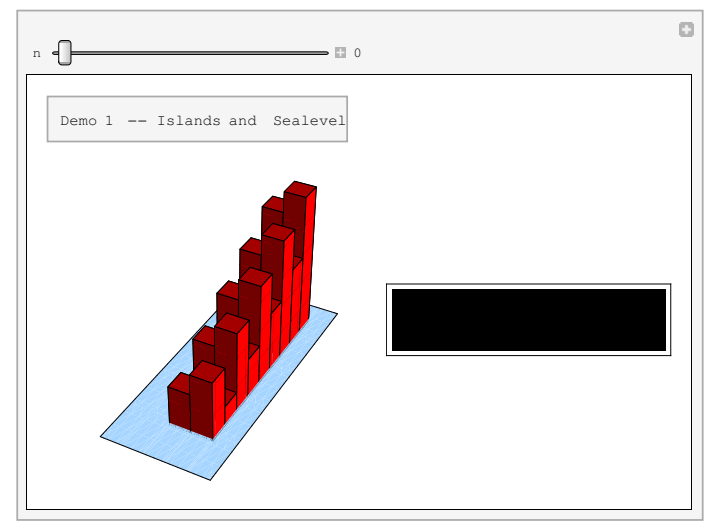

(a)

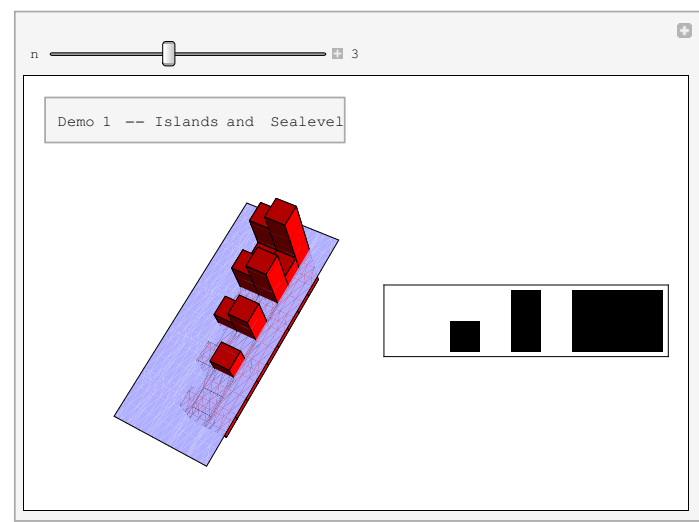

(b)

4.48. ábra. Szigetrendszerek és szerkezetük Mathematicaban

Az alkalmazás elindítása után a bal oldalon egy szigetrendszer háromdimenziós ábráját láthatjuk. (Ez, hasonlóan a korábbiakhoz, természetesen forgatható a legjobb rálátás biztosítása végett.) A képernyố jobb oldalán pedig az éppen aktuális vízszint esetében felbukkanó új szigetek vetülete látható. A játék kezdetén a vízszint $0, \mathrm{~s}$ így természetesen egyetlen szigetünk van, a fősziget. A felhasználói ablak tetején található csúszka segítségével egyesével emelhetjük a vízszintet. A vízszint emelkedésének hatására újabb és újabb szigetek túnnek fel, míg végül a teljes szigetrendszer a víz alá merül. Mindez a bal oldali ábrán teljes mértékben nyomon követhetô, hiszen ott a szigetek víz feletti, és víz alatti része egyaránt látszik. A felhasználónak ezúttal is van módja tetszóleges rács megadására, tetszóleges magasságú mezókkel. A játéknak ezúttal konkrét célja nincs, így azt akár mi magunk is meghatározhatjuk.

\subsubsection{Módszertani összefoglaló}

A fejezetben eljutottunk a korábbi kísérletek által intuitívan kialakított sejtések konkrét megfogalmazásáig, bizonyításáig. Megalkottuk a maximális és minimális sziget fogalmát, bevezettük a szigetrendszer gráfját, valamint megvizsgáltuk a szigetrendszerek és a gráfok kapcsolatát. A kitúzött feladatok a következóképp csoportosíthatók:

(a) Szigetek kölcsönös helyzetének vizsgálata (4.50.-4.55.).

(b) Speciális szigetek vizsgálata (4.56.-4.62.).

(c) A matematikai modell felállítása (4.63.-4.67.).

(d) Ismerkedés a modellünkkel (4.68.-4.70.). 
(e) Speciális szigeteink és a modellünk kapcsolatának vizsgálata (4.71.-4.72.).

(f) Szigetrendszerek vizsgálata a gráfjaikon keresztül (4.73.).

A bemutatott Mathematica alkalmazás segítségével a diákok maguk fedezhetik fel a szigetrendszerek egy már magasabb absztrakciós szinten lévô modelljét. Így láthatjuk, hogy a számítógépes kísérletek az absztrahálásban is segítségünkre lehetnek. A tanulók számára a bemutatott feladatok segítségével újabbakat is kitűzhetünk, melyek vonatkozhatnak például speciális gráffal rendelkezô szigetrendszerek létrehozására is. Itt a korlátozó paraméterek, illetve a paraméterek számának változtatásával tudunk kitûzni különbözô szintû feladatokat. A Mathematica demonstráció felhasználásával lehetőségünk van a feladatok számának gyors többszörözésére, illetve a digitális bennszülöttek hatékony motiválására.

\subsection{Szigetek maximális száma}

„Azt hiszem, hogy a matematikai minimum és maximum problémák azért rokonszenvesek, mert mindennapos problémáinkat idealizálják." (PÓLYA GYÖRGY)

\subsubsection{Bevezetés}

Ebben a fejezetben célunk az $m \times n$-es rácson elhelyezhetô szigetek maximális számának meghatározása abban az esetben, ha a magasságfüggvény nem korlátos. E feladat elsố megközelítésre túl bonyolult, ezért speciális esetek vizsgálatával kezdünk. Ez segítheti az intuíciót és a heurisztikát, valamint megalapozhatja analógiák kialakulását. A speciális esetek vizsgálatát történeti előzmények is indokolhatják. Egy részletes felépítés megtalálható a szerző [110] cikkében (Attila Máder, Róbert Vajda. Elementary Approaches to the Teaching of the Combinatorial Problem of Rectangular Islands, International Journal of Computers for Mathematical Learning, 15(3), 267-281, 2010.).

A fejezet egyes eredményeinek megalkotásához használjuk bátran a 4.3.6. fejezet Mathematica animációját.

\subsection{2. $\quad$ Szigetek az $1 \times n$-es rácson}

4.74. Feladat. Állítsuk rácsunkat a 4.3.6. fejezet játékában $1 \times n$-esre $(n=$ $1,2,3, \ldots)$, majd próbáljunk meg minél több szigetet létrehozni. Ezek után próbáljuk megoldani a következő feladatot.

4.75. Feladat. Legfeljebb hány szigetünk lehet egy

(a) $1 \times 2$-es,

(b) $1 \times 3$-as, 
(c) $1 \times 4$-es,

(d) $1 \times 5$-ös rácson?

Megoldás. Fenti kísérleteinkbôl kialakulhat a sejtés, hogy a maximális szigetszám az egyes esetekben rendre 2, 3, 4, illetve 5. A számítógép segítségével lehetséges megvalósítások tömkelegét találhatjuk, ezek közül egyet-egyet mutatnak az alábbi ábrák.

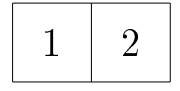

(a)

\begin{tabular}{|l|l|l|}
\hline 1 & 2 & 3 \\
\hline
\end{tabular}

(b)

\begin{tabular}{|l|l|l|l|}
\hline 1 & 2 & 3 & 4 \\
\hline
\end{tabular}

(c)

\begin{tabular}{|l|l|l|l|l|}
\hline 1 & 2 & 3 & 4 & 5 \\
\hline
\end{tabular}

(d)

4.49. ábra. Szigetek kis rácsokon

4.76. Feladat. Milyen sejtés fogalmazható meg az elôzô feladat eredményéből?

Megoldás. Sejtésünk a következô.

4.77. Sejtés. A szigetek maximális száma az $1 \times n$-es téglalap esetében $n$.

Bizonyítás. A bizonyítás $n$-szerinti teljes indukcióval történik. Az állítás könnyen ellenôrizhetô módon $n=1,2$ esetén fennáll. Tegyük fel most, hogy az állítás teljesül valamely $n \geq 2$-ig minden $n$-re. Legyen a rácsunk $n+1$ hosszú. Az általánosság megszorítása nélkül feltehetô, hogy a vizsgált szigetrendszer kanonikus alakban adott. Ekkor tudjuk (4.32. feladat), hogy van a rácson 1 magasságú mezô. Tekintsük az egyik ilyen mezôt. Ez három részre vágja rácsunkat: a mezô elôtti $k$ hosszú részre, magára az 1 magas mezôre, és az ezen mezô utáni $n-k$ hosszú részre.

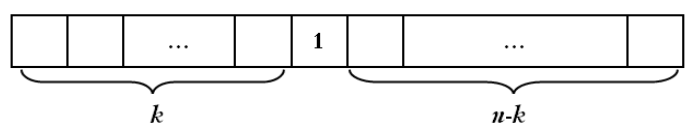

4.50. ábra. Szigetek - az elsô vágás

Ekkor ezen, $n+1$ hosszú rácson a szigetek $I$ számára az indukciós feltevés szerint fennáll, hogy $I \leq k+n-k+1$, hiszen a $k$ hosszú mezôn legfeljebb $k$, az $n-k$ hosszún legfeljebb $n-k$ sziget van, illetve még sziget az egész rács. Így beláttuk, hogy egy $n+1$ hosszú rács esetén a szigetek számára: $I \leq k+n-k+1=n+1$. Egy $n$ hosszú rács esetén az $n$ számú sziget realizálható is, így a becslés éles, nem javítható.

\begin{tabular}{|l|l|l|l|l|l|l|}
\hline 1 & 2 & 3 & $\cdots$ & $\cdots$ & $n-1$ & $n$ \\
\hline
\end{tabular}

4.51. ábra. Szigetek - a becslés éles 
4.78. Megjegyzés. Számítógéppel végzett tömeges kísérleteink között nagy valószínûséggel akad olyan is, melyben sikerült az optimális szigetszámot produkálni úgy, hogy volt 1 magas mezô is a rácson. Így a fenti indukciós bizonyítás lényegi észrevétele máris a rendelkezésünkre áll. Bizonyításunk pusztán annyival mond többet, hogy ez mindig elérhető. Ezzel ismét bizonyítékát adtuk annak, hogy a számítógéppel végzett nagyszámú kísérleteknek a bizonyítások előkészítésében és azok megalapozásában is fontos szerepe van.

Eredményünk mélyebb megértését itt is segíthetjük inverz feladatokkal.

4.79. Feladat. Egy $1 \times n$-es téglalap esetén adjuk meg a magasságokat úgy, (adjunk meg olyan magasságfüggvényt), melyre a szigetek száma
(a) 1 ,
(b) 2 ,
(c) 3 ,
(d) $\lfloor n / 2\rfloor$,
(e) $\lceil n / 2\rceil$,
(f) $n-2$,
(g) $n-1$.

Megoldás. Egy-egy lehetséges megoldást mutatnak az alábbi ábrák az $n=7$ esetben.

\begin{tabular}{|l|l|l|l|l|l|l|}
\hline 1 & 1 & 1 & 1 & 1 & 1 & 1 \\
\hline
\end{tabular}

(a)

\begin{tabular}{|l|l|l|l|l|l|l|}
\hline 1 & 1 & 1 & 1 & 1 & 2 & 3 \\
\hline
\end{tabular}

(c)

\begin{tabular}{|l|l|l|l|l|l|l|}
\hline 1 & 1 & 1 & 1 & 2 & 3 & 4 \\
\hline
\end{tabular}

(e)

\begin{tabular}{|l|l|l|l|l|l|l|}
\hline 1 & 2 & 3 & 4 & 5 & 6 & 6 \\
\hline
\end{tabular}

$(\mathrm{g})$

\begin{tabular}{|l|l|l|l|l|l|l|}
\hline 1 & 1 & 1 & 1 & 1 & 1 & 2 \\
\hline
\end{tabular}

(b)

\begin{tabular}{|l|l|l|l|l|l|l|}
\hline 1 & 1 & 1 & 1 & 1 & 2 & 3 \\
\hline
\end{tabular}

(d)

\begin{tabular}{|l|l|l|l|l|l|l|}
\hline 1 & 2 & 3 & 4 & 5 & 5 & 5 \\
\hline
\end{tabular}

(f)

4.52. ábra. A 4.79 feladat megoldásai

Az $1 \times n$-es rács vizsgálatát egy nehezebb feladat kitúzésével zárjuk.

4.80. Feladat. Igazoljuk, hogy az $1 \times n$ rácsot az $1,2, \ldots, n$ számok bármely permutációjával kitöltve $n$ szigetünk lesz. 
4.81. Megjegyzés. Az, hogy a fenti állítás igaz, egyáltalán nem nyilvánvaló. Így a kezdet kezdetén még abban sem lehetünk biztosak, hogy tényleg bizonyítani, vagy esetleg cáfolni kell-e. Erre azonban a már megismert Mathematica játékkal való munka néhány perc után választ ad. Most a számítógépekkel végzett kísérleteink egy nehezebb probléma megoldásában mutattak irányt.

\subsubsection{Szigetek az $2 \times n$-es rácson}

A $2 \times n$-es rácson elhelyezhetô szigetek maximális számának meghatározásához a kétoldali közelítés módszerének segítségével kezdünk hozzá. Először egy felsô, majd egy alsó korlát meghatározására vezetô, számítógéppel támogatott felfedeztetési lehetôséget mutatunk be.

\section{Elsô megközelítés - sejtés a felsô korlátra}

4.82. Feladat. Legfeljebb hány sziget lehet egy
(a) $2 \times 1$-es,
(b) $2 \times 2$-es,
(c) $2 \times 3$-as,
(d) $2 \times 4$-es,
(e) $2 \times 5$-ös rácson?

Megoldás. A szigetek száma, például a 4.3.6. fejezet játékának segítségével kialakult sejtésünk szerint, rendre $2,3,5,6,8$.

A feladatunk ezek után az általánosítás. A következókben arra mutatunk példát, hogyan segítheti egy egyszerúen használható számítógépes program a mintafelismerést.

4.83. Feladat. Hogyan folytatható a fenti sorozat? Milyen minta ismerhető fel? Milyen kapcsolatban lehet ez a szigetek elhelyezkedésével?

Megoldás. A sorozat folytatásában, a képzési szabály (az n-edik tag explicit, illetve rekurzív alakjának) megtalálásában is segítségünkre lehet a számítógép. Használhatjuk például a korábbiakban már megismert és hasonló szituációban bevált OEIS alkalmazást [124]. A weblap által felkínált mezóbe kell újfent beírnunk sorozatunk ismert tagjait, s válaszul megkapjuk azokat a sorozatokat (azon sorozatok közül az ismerteket, illetve az adatbázisban szereplô releváns találatokat) melyekre az általunk megadott minta illeszkedik. Természetesen minél több tagot adunk meg, annál kevesebb, s jobban illeszkedő sorozatot kapunk. Mivel a kapott válaszok halmaza jelenleg elég kaotikus, a feladatunk nem lehet más, mint további konkrét rácsok vizsgálata, s még több tag kiszámítása. 
A fentiek kiváló például szolgálnak arra, hogy mit sem ér a számítógépes segítség értő felhasználó nélkül. Itt kap szerepet a tanácsadó szellemú, a felfedezéseket megfelelô irányba terelô tanár. Az ô feladata a kézi, és a számítógéppel segített kísérletek összehangolása, hogy azok egymást segítve eredményre tudjanak vezetni.

4.84. Feladat. Hány sziget lehet legfeljebb egy
(a) $2 \times 6$-es,
(b) $2 \times 7$-es,
(c) $2 \times 8$-as,
(d) $2 \times 9$-es rácson?

Megoldás. Sejtésünk szerint a válasz rendre 9, 11, 12, 14.

4.85. Megjegyzés. A további konkrét esetek vizsgálatával nem csak az explicit alak megtalálása felé tehetünk lépéseket, de ha ez nem sikerülne, módszerünk arra is alkalmas, hogy a következő megközelítési mód ötletét megalapozza.

4.86. Feladat. Az OEIS segítségével keressünk meg sorozatunk lehetséges további tagjai közül még néhányat. Milyen sejtések fogalmazhatók meg a program által felkínált lehetôségek segítségével sorozatunk $n$-edik tagjára vonatkozóan?

Megoldás. A program által felkínált első lehetôség a folytatásra: 2, 3, 5, 6, 8, 9 , $11,12,14,15,17,18,20,21,23,24,26,27,29,30,32,33,35,36$, $38,39,41,42,44,45,47,48,50,51,53,54,56,57,59,60,62,63$, $65,66,68,69,71,72,74,75,77,78,80,81,83,84,86,87,89,90$, $92,93,95,96,98,99$, az $n$-edik tagra vonatkozóan pedig: The map $n->$ a $(n)$ (where $\mathrm{a}(\mathrm{n})=3 \mathrm{n} / 2$ if $\mathrm{n}$ even or $(3 n+1) / 2$ if $\mathrm{n}$ odd). Ezzel a következố sejtés fogalmazható meg.

4.87. Sejtés. Jelölje $a_{n}$ a $2 \times n$-es rácson képezhetô szigetek maximális számát. Ekkor

$$
a_{n}=\left\{\begin{array}{ll}
\frac{3 n}{2}, & \text { ha } n \text { páros } \\
\frac{3 n+1}{2}, & \text { ha } n \text { páratlan }
\end{array}=\left\lfloor\frac{3 n+1}{2}\right\rfloor\right.
$$

\section{Második megközelítés - egy biztos alsó korlát}

4.88. Feladat. Adjunk alsó becslést a szigetek maximális számára a $2 \times n$-es rácson. (Most tehát nem az a célunk, hogy a $2 \times n$-es rácson maximális számú szigetet produkáljunk, hanem csak az, hogy adjunk egy olyan konstrukciót, amely megvalósítható, és ,viszonylag sok” szigetet ad a rácson.) 
Megoldás. Már korábban láttuk, hogy az $1 \times 2$-es rácson legfeljebb 2, míg a $2 \times 2$-es rácson legfeljebb 3 szigetünk lehet. (Persze nagyobb rácsokra is vannak eredményeink, de jelen megközelítéshez ennyi is elég.) Azt már láthattuk az $1 \times n$-es rács esetében (4.77. sejtés), hogy mindig van olyan optimális konstrukció, amelyben valamely mező magassága 1. Mivel 1 magas mező csak a fősziget része lehet, ez úgy is értelmezhetô, mint egy vágás a rácson. Tulajdonképpen ezen vágás létezésen múlt indukciós bizonyításunk. Ha egy ilyen vágás létét feltételezzük a $2 \times n$-es rács esetében is, azzal nem biztos, hogy maximális számú szigetet tudunk előállítani (ez nem is célunk most), de egy alsó korlátot tudunk találni, s lehetôségünk nyílik egy rekurzió felállítására is. Jelölje $b_{n}$ a következô, vágásos konstrukció által a $2 \times n$-es rácson kialakított szigetek maximális számát. A korábbiakból tudjuk, hogy $b_{1}=2, b_{2}=3$. Legyen most rácsunk $2 \times n$-es, ahol $n>2$. Egy lehetséges konstrukció a következô. Hasítsunk le rácsunk egyik végéból egy $2 \times 2$-es részt, s töltsük fel az utolsó oszlopot egynél nagyobb magasságértékekkel úgy, hogy ott 2 sziget keletkezzen (ez megtehető), az utolsó előtti oszlopot pedig egyesekkel.

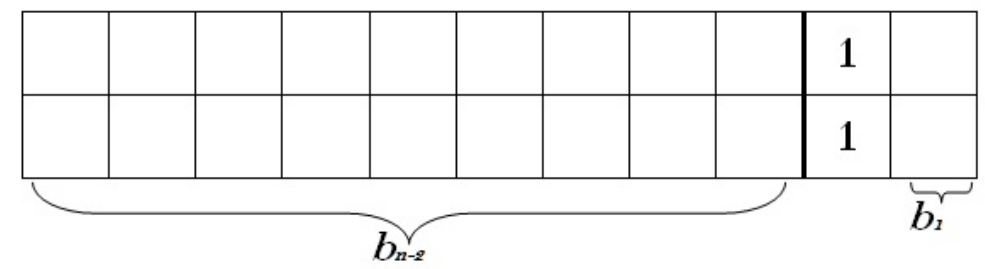

4.53. ábra. Vágás a $2 \times n$-es rácson

Ahhoz, hogy az egyesekből álló utolsó előtti oszlop ténylegesen elvágóként funkcionáljon szükséges, hogy az elsố, $n-2$ hosszú részben minden felhasznált magasság nagyobb legyen mint 1. Ez az általánosság megszorítása nélkül feltehetô, hiszen ha az elsố részben is lenne egyes magasság, nincs más dolgunk, mint minden itt szereplô magasságértéket megnövelni egy tetszőleges, de minden mezőre azonos pozitív egész értékkel (például eggyel). Ekkor az elsố $n-2$ hosszú részen keletkezik $b_{n-2}$ számú sziget, a hátsó oszlopban kettô, és ott van még a fôszigetünk is. Ezen konstrukció által adott szigetek számára kaptuk tehát: $b_{1}=2, b_{2}=3, b_{n}=b_{n-2}+3$, ha $n>2$. Feladatunk ezen másodrendú lineáris inhomogén rekurzió megoldása. A számítások kézzel történô elvégzése helyett itt is segítségül hívhatjuk a számítógépet. Kiváló eszköz a rekurzió megoldására valamely komputer-algebrai program, például a Mathematica 8.0. Itt egy egyszerú kód segítségével megadhatjuk, s meg is oldhatjuk a rekurziót. Az

RSolve $[\{b[n]==b[n-2]+3, b[1]==2, b[2]==3\}, b, n]$

parancs hatására kapjuk:

$$
\frac{1}{4}\left(1-(-1)^{n}+6 n\right)
$$


vagyis

$$
b_{n}=\frac{6 n+1+(-1)^{n+1}}{4}=\left\lfloor\frac{3 n+1}{2}\right\rfloor .
$$

A számítógép által szolgáltatott eredmény felhasználásával mi magunk is bebizonyíthatjuk a fenti összefüggést, például teljes indukcióval a következô módon.

Tudjuk, hogy $b_{1}=2=\left\lfloor\frac{3 \cdot 1+1}{2}\right\rfloor$ és $b_{2}=3=\left\lfloor\frac{3 \cdot 2+1}{2}\right\rfloor$. Tegyük fel, hogy az állítás teljesül minden $n$-nél kisebb pozitív értékre. Ekkor

$$
b_{n}=b_{n-2}+b_{1}+1=\left\lfloor\frac{3(n-2)+1}{2}\right\rfloor+2+1=\left\lfloor\frac{3 n+1}{2}\right\rfloor .
$$

4.89. Megjegyzés. Ezzel is példáját láthattuk annak, hogyan segíthetik a számítógéppel végzett vizsgálatok a bizonyossági szint növelését, valamint hogyan válik lehetôvé segítségükkel a számítások, bizonyítási módszerek egyszerúsítése.

\section{Megközelítéseink összevetése}

4.90. Feladat. Milyen sejtést fogalmazhatunk meg a két megközelítésben kapott eredményeink segítségével?

4.91. Sejtés. A $2 \times n$-es rácson maximum $I_{2 \times n}=\left\lfloor\frac{3 n+1}{2}\right\rfloor$ szigetünk lehet.

4.92. Megjegyzés. Eredményünk mélyebb megértését itt is segíthetjük inverz feladatokkal a 4.79. feladat mintájára.

Az általános, $m \times n$-es eset tárgyalása elôtt még érdemes részletesen megvizsgálnunk még egy speciális esetet, a $3 \times n$-es rács esetét. Ez a rács még kellóképp egyszerú ahhoz, hogy gyorsan átlátható legyen, viszont elegendően összetett ahhoz, hogy az általános eset megoldási módszere körvonalazódni tudjon általa. 


\subsubsection{Szigetek az $3 \times n$-es rácson}

„A módszer olyan fogás, melyet legalább kétszer alkalmazunk.” (PóLYA GYÖRGY)

4.93. Feladat. Az $1 \times n$-es és a $2 \times n$-es rácsoknál megismert módszer segítségével próbáljunk egy felsố és egy alsó becslést találni a szigetek számára a $3 \times n$-es rácson.

Megoldás. Használjuk tehát elôzô módszereinket! Kis rácsokon számításokat, vizsgálatokat, kísérleteket végezve azt tapasztaljuk, hogy a $3 \times 1,3 \times 2,3 \times 3, \ldots$ rácson legfeljebb rendre $3,5,7,9,11, \ldots$ számú sziget lehet. Különösebb segítség nélkül is kialakulhat a sejtés, hogy a szigetek maximális száma a $3 \times n$-es rácson $2 n+1$. De tényleg lehet ennyi szigetünk? Az előző, vágásos technika segítségével könnyedén felírhatunk egy, a szigetek számára vonatkozó alsó becslést leíró rekurziót. Jelölje $b_{n}$ a jól ismert, vágásos technika által szolgáltatott szigetek számát a $3 \times n$-es rácson. Ekkor $b_{1}=3$, $b_{2}=5$. Ha $n>2$, akkor pedig a következô másodrendû lineáris rekurzió írható fel: $b_{n}=b_{n-2}+4(n>2)$.

A rekurziót most már könnyedén meg tudjuk oldani az előzô hasonló parancs apró módosításával.

RSolve $[\{b[n]==b[n-2]+4, b[1]==3, b[2]==5\}, b[n], n]$

A Mathematica válasza:

$$
b_{n}=1+2 n .
$$

4.94. Megjegyzés. Persze a számítógép válasza itt is bizonyítható teljes indukcióval a 4.88. feladat megoldásában látottakkal analóg módon.

Az alsó és a felsô becslés most is találkozik, így meggyốzô sejtésünk alakulhat ki a $3 \times n$-es esetben is a szigetek maximális számára vonatkozóan.

4.95. Sejtés. A $3 \times n$-es rácson a szigetek maximális száma $I_{3 \times n}=2 n+1$.

4.96. Megjegyzés. A számítógéppel végzett munkának itt is megjelenik egy fontos előnye. A korábbi kódok jól használhatók most is, néhány paraméter megváltoztatása után. Nem szükséges új, hosszadalmas számításokba bonyolódni, melyek nem csak, hogy elveszik a diákok kedvét a további munkától, de alkalmasak arra is, hogy csak rájuk koncentráljunk, így éppen a feladat lényege vész el a megoldására felsorakoztatott bonyolult eszköztár mögött. 


\subsubsection{Szigetek az $m \times n$-es rácson - egy alsó becslés}

A fenti $1 \times n, 2 \times n, 3 \times n$-es rácsokon végzett vizsgálatok után jobb esélyekkel próbálkozhatunk meg az általános probléma megoldásával. Érdemes azonban az alsó és felsố becslésre vonatkozó vizsgálatokat itt is élesen elkülöníteni. Ebben a részen az alsó becslésnek járunk utána.

4.97. Feladat. Adjunk alsó becslést a fent megismert vágásos technika segítségével a szigetek számára az $m \times n$-es rácson.

Megoldás. Jelölje az ily módon az $m \times n$-es rácson keletkezô szigetek számát $b_{n}$. A fentiek alapján felírhatjuk a következô rekurzív összefüggést, ahol is $b_{1}=m$ a 4.77. tétel, $b_{2}=\frac{6 m+1+(-1)^{m+1}}{4}$ pedig a a 4.88. feladat alapján adódott.

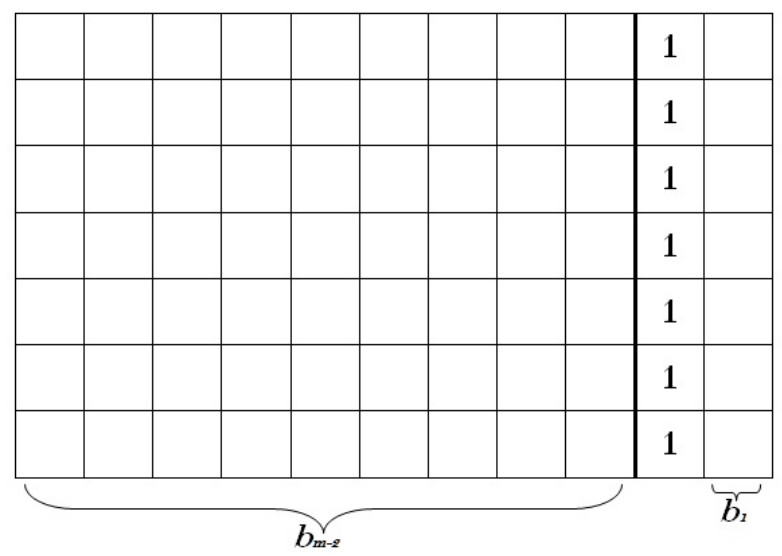

4.54. ábra. Vágás az $m \times n$-es rácson

Itt már egy paraméteres másodrendû lineáris rekurzió megoldása a feladatunk, melyet a fentiekben többször használt Mathematica parancs újabb módosításával egyszerúen megtehetünk:

RSolve $\left[\left\{\mathrm{b}[\mathrm{n}]==\mathrm{b}[\mathrm{n}-2]+\mathrm{m}+1, \mathrm{~b}[1]==\mathrm{m}, \mathrm{b}[2]==\frac{6 m+1+(-1)^{m+1}}{4}\right\}, \mathrm{b}, \mathrm{n}\right]$

A program által válaszul adott

$$
\frac{1}{8}\left(-5-(-1)^{m}-(-1)^{n}-(-1)^{m+n}+4 m+4 n+4 m n\right)
$$

összefüggést egyszerúsítve:

$$
b_{n}=\left\lfloor\frac{m n+m+n-1}{2}\right\rfloor
$$

adódik. 
4.98. Megjegyzés. Ekkor persze $m$ helyébe egyet, kettőt illetve hármat helyettesítve visszakapjuk a 4.77., 4.91., illetve a 4.95. pontok eredményeit.

4.99. Megjegyzés. A vizsgált paraméteres másodrendû lineáris rekurzió megoldása a korábban használt kódok egyszerú módosításával gyorsan, egyszerüen elvégezhetô, magasabb szintú matematikai, és mindenféle programozói ismeret nélkül.

4.100. Feladat. Oldjuk meg a fenti rekurziót az előzô, számítógéppel megalkotott eredményünk felhasználásával.

Megoldás. Könnyen látható, hogy $b_{1}=\left\lfloor\frac{m \cdot 1+m+1-1}{2}\right\rfloor=m$ és $b_{2}=\left\lfloor\frac{m \cdot 2+m+2-1}{2}\right\rfloor=$ $\left\lfloor\frac{3 m+1}{2}\right\rfloor$. Tegyük most fel, hogy állításunk minden $n$-nél kisebb pozitív egész értékre teljesül. Ekkor $b_{n}=b_{n-2}+b_{1}+1=\left\lfloor\frac{m \cdot(n-2)+m-1+(n-2)}{2}\right\rfloor+m+1=\left\lfloor\frac{m n+m+n-1}{2}\right\rfloor$.

4.101. Megjegyzés. Ezen a ponton különösen fontos hangsúlyozni azt, hogy nem azt állítjuk, hogy ennél több sziget nem keletkezhet az $m \times n$-es rácson, hanem csak azt, hogy egy viszonylag egyszerú rekurzív technikával ennyi sziget biztosan kreálható.

\subsubsection{Szigetek az $m \times n$-es rácson - egy felső becslés}

A felsố becslés kialakítása során is több úton indulhatunk el. Ezek közül egyre mutatunk példát. Ennek során megmutatjuk, milyen kapcsolat van egy szigetrendszer gráfja, s a szigetrendszer által elfoglalt, eddig nem is említett rácspontok között.

\section{Rácspontok}

A következô néhány feladat célja rácsunk jobb megismertetése. Eddig csupán a rácson található szigetekkel, esetleg a rácsot alkotó cellákkal foglalkoztunk, de magukkal a rácspontokkal még nem. Pedig a rácspontoknak fontos, és jól meghatározható korlátozó szerepe van a szigetek számát illetően. Az alábbi feladatok ennek felfedezését készítik elő.

4.102. Feladat. Hány rácspont található egy $m \times n$-es rácson?

Megoldás. A rácspontok száma egy $m \times n$-es rácson $(m+1)(n+1)$.

Már többször említésre került, hogy a minimális szigetek különösen fontos szerepet játszanak a szigetek maximális számának meghatározásában. A következô feladatban összekapcsoljuk a minimális szigetek és rácspontok fogalmát. 
4.103. Feladat. Legalább hány rácspontot foglal el egy minimális sziget?

Megoldás. Egy minimális sziget legalább négy rácspontot foglal el. Az alábbi ábrán ezt szemléltetjük.

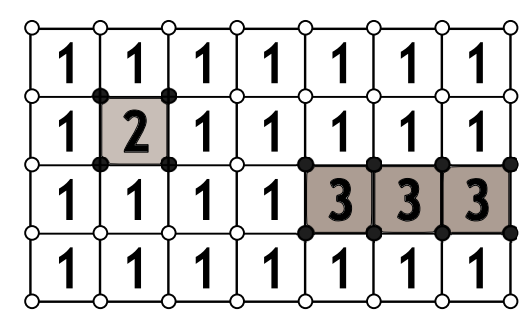

4.55. ábra. Rácspontok és minimális szigetek

\section{Gráfok és rácspontok}

A szigetek maximális számára vonatkozó felsô becslésünk a szigetrendszer gráfjának és a szigetrendszer szigetei által elfoglalt rácspontok számának kapcsolatán múlik. Az alábbiakban ezt készítjük elő, elôször egy, a fa csúcsai és levelei száma közötti kapcsolatot feltáró tétellel.

4.104. Tétel. Ha egy $T$ (gyökeres) fának minden nemlevél csúcsának legalább két fia van, akkor a fa $V$ csúcsára és $l$ levelére: $V \leq 2 l-1$.

Bizonyítás. Legyen $T$ egy gyökeres fa $V$ csúccsal és $l$ levéllel, melyben minden nemlevél csúcsnak legalább két fia van. Számoljuk meg, illetve becsüljük a gráf éleinek számát kétféle módon. Mivel a gyökér kivételével minden csúcsnak pontosan egy apja van, ezért az élek száma $V-1$. Viszont, mivel minden nemlevél csúcsnak legalább két fia van, ezért az élek száma nem lehet kisebb, mint $2(V-l)$. Így kapjuk $V-1 \geq 2(V-l)$, azaz $V \leq 2 l-1$.

4.105. Feladat. Szigetrendszereink gráfjai eleget tesznek-e a 4.104. tétel feltételeinek?

Megoldás. Nem, erre korábbi szigetrendszereink között számos példát találhatunk (pl. 4.40. ábra).

Kísérletekkel is elérhetjük, hogy fel tudjuk fedezni a „hiba” okát. Erre mutat példát a következô néhány feladat. 
4.106. Feladat. Mi történhet egy kanonikus alakban megadott szigetrendszer esetében egy szigettel a vízszint emelkedésével?

\section{Megoldás.}

(a) eltûnik (ha minden pontja alacsonyabb, mint az új vízszint),

(b) több szigetre esik szét (ha van az új, aktuális vízszintnél magasabb és alacsonyabb pontja is, ez utóbbi a sziget „belsejében”),

(c) egy része víz alá kerül (ha van az új, aktuális vízszintnél magasabb és alacsonyabb pontja is, ez utóbbi a sziget „szélén”).

Az alábbi ábra a szigetek lehetséges változásaira mutat példát a vízszint emelkedésével. Az alapállapot ((a) ábra) esetében a teljes rács egyetlen összefüggố sziget. A vízszint emelésével elôször ((b) ábra) szigetünk három kisebb szigetre esik szét. A vízszint további emelkedése esetén ((c) ábra) láthatjuk, amint a bal oldali oszlop szigetének egy része a víz alá süllyed, a harmadik oszlop szigete több kisebb részre esik szét, míg az ötödik oszlop szigete eltúnik.

\begin{tabular}{|l|l|l|l|l|}
\hline 2 & 1 & 3 & 1 & 2 \\
\hline 3 & 1 & 2 & 1 & 2 \\
\hline 4 & 1 & 3 & 1 & 2 \\
\hline
\end{tabular}

(a)

\begin{tabular}{|l|l|l|l|l|}
\hline 2 & 1 & 3 & 1 & 2 \\
\hline 3 & 1 & 2 & 1 & 2 \\
\hline 4 & 1 & 3 & 1 & 2 \\
\hline
\end{tabular}

(b)

\begin{tabular}{|l|l|l|l|l|}
\hline 2 & 1 & 3 & 1 & 2 \\
\hline 3 & 1 & 2 & 1 & 2 \\
\hline 4 & 1 & 3 & 1 & 2 \\
\hline
\end{tabular}

(c)

4.56. ábra. Változó szigetek

4.107. Megjegyzés. A kanonikus reprezentáció biztosítja azt, hogy ha valami kiemelkedik a rácsunkból, akkor az téglalap alakú és sziget. Így a rácsunkból a vízszint emelésével minden esetben téglalap alakú tartományok jönnek létre, melyek szigetek is.

4.108. Megjegyzés. Ebben az esetben is érdemes a 4.4.4. fejezet Mathematica demonstrációját segítségül hívni. Itt, a paraméterek változtatásával könnyedén találhatunk a fenti tételt kielégítő, illetve ki nem elégítő szigetrendszereket is. Mivel nagyszámú kísérletet végeztünk viszonylag rövid idô alatt, így arra is van módunk, hogy magunk fedezzük fel, hogy mi a „hibája” a tételt ki nem elégítô szigetrendszereknek. A számítógépes kísérletek szerepe itt a példák, ellenpéldák, közös tulajdonságok keresésében rejlik.

4.109. Feladat. Milyenek azok a szigetek, melyeknek csak egy fiuk van?

Megoldás. Ezek azok a szigetek, melyek a vízszint emelkedésével nem túnnek el, nem esnek szét több kisebb szigetre, hanem egy részük víz alá merül. 
4.110. Feladat. Hogyan tehetnénk a szigetrendszerek gráfjait a 4.104. tétel feltételeit kielégítóvé?

Megoldás. Nevezzük a vízszint emelkedésével egy részüket elveszítô szigetek víz alá merülô részeit félszigetnek, s rendeljünk a félszigetekhez is a korábbiaknak megfelelóen, a tartalmazási relációba illeszkedôen, egy-egy csúcsot a gráfban.

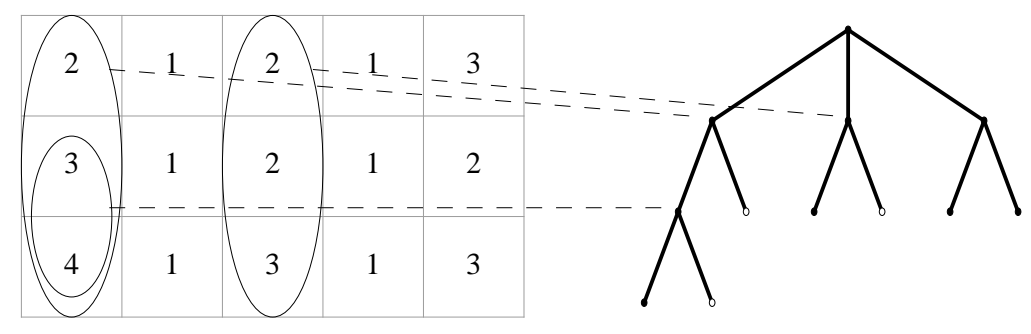

4.57. ábra. Félszigetek

Ekkor az eddig mindössze egy fiúval rendelkezô csúcsoknak is legalább két fiuk lesz. Nevezzük az így kapott gráfot a szigetrendszer kiegészített gráfjának.

A minimális szigetek rácspontjainak vizsgálata után indokolt a szigetrendszer kiegészített gráfjában szintén levélként feltûnő félszigetek rácspontjainak vizsgálata is. Ezt végezzük el a következô feladat formájában.

4.111. Feladat. Hány rácspontot foglal el „saját jogán” egy félsziget? (Azaz hány olyan rácspont van egy adott félszigethez tartozóan, melyet elfoglal a félszigetet befoglaló sziget, de nem foglal el a befoglaló sziget egyetlen fia?)

Megoldás. Legalább kettôt. Az alábbi ábra ezt mutatja.

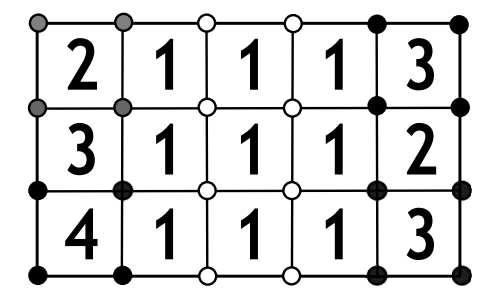

4.58. ábra. Rácspontok és félszigetek

A következô feladattal megkezdjük a rácspontok és a szigetrendszer kiegészített gráfjának vizsgálatából adódó felsô becslés elókészítését.

4.112. Feladat. A fenti, rácspontokra vonatkozó eredmények (4.103. és 4.111. feladat) alapján milyen becslés adható a minimális szigetek és félszigetek együttes számára? 
Megoldás. Könnyú meggondolni, hogy a minimális szigetek diszjunktak, még csak közös határpontjuk sem lehet. Ebből következik, hogy különbözô minimális szigetek páronként külöbözô rácspontokat fednek le. Az egy adott félsziget által „elfoglalt” rácspontok bevezetéséból (4.111. feladat) pedig az következik, hogy a különböző félszigetek által elfoglalt rácspontok is páronként különböznek. Az is világos, hogy minimális sziget és félsziget sem foglalhat el közös rácspontot. Így, ha a minimális szigeteink száma $s$, a félszigeteké $f$, akkor $4 s+2 f \leq(m+1)(n+1)$.

4.113. Feladat. A szigetrendszereink kiegészített gráfjára vonatkozó tételünk, valamint a fenti becslés összekapcsolásával milyen felső becslést adhatunk a szigetek maximális számára az $m \times n$-es rácson $[11,110]$ ?

Megoldás. Legyen szigetrendszerünk kiegészített gráfjának $V$ csúcsa, ez azt jelenti, hogy $V$ szigetünk és félszigetünk van összesen. Ekkor $V \leq 2 l-1$, ahol $l$ a kiegészített gráf leveleinek száma, vagyis $l=s+f$, ahol $s$ a minimális szigetek, $f$ a félszigetek száma. Ekkor a szigetek $V-f$ számára a következô írható.

$V-f \leq 2 l-1-f=2(f+s)-1-f=2 s+f-1=\frac{4 s+2 f}{2}-1 \leq \frac{(m+1)(n+1)}{2}-1$.

Mivel $V$ és $f$ egész, ez a következô alakban is írható:

$$
V-f \leq\left\lfloor\frac{m n+m+n-1}{2}\right\rfloor
$$

\subsubsection{Szigetek az $m \times n$-es rácson}

Ezek után nincs más dolgunk, mint az alsó és felső becslésünk összekapcsolása.

4.114. Feladat. Az alsó (4.97. feladat) és felsô (4.113. feladat) becslés alapján mit állíthatunk az $m \times n$-es rács szigeteinek maximális számáról?

Megoldás. Mivel az alsó, és a felsố becslés ugyanazt az értéket szolgáltatta a szigetek maximális számára, ezért megállapíthatjuk, hogy a szigetek maximális száma az $m \times n$ es rácson

$$
\left\lfloor\frac{m n+m+n-1}{2}\right\rfloor .
$$

4.115. Megjegyzés. Az, hogy az alsó és felsô becslés „összeér”, különösen szép. A fenti teljes gondolatmenet a kétoldali közelítés módszerének egy szép alkalmazása. Az alsó és felsố becslés találkozásának van egy említésre méltó következménye is, mégpedig a vágásos technika hatékonysága. Ez azt jelenti, hogy bármely rácson tudunk olyan optimális szigetrendszert kreálni, mely tartalmaz a fentiekben megismert vágást. 


\subsubsection{Módszertani összefoglaló}

A fejezetben speciális esetek vizsgálatán elindulva meghatároztuk az $m \times n$-es rács szigeteinek maximális számát. A számítógéppel végzett kísérleteink ezúttal segítségünkre voltak a sejtések kialakításában és megszilárdításában (4.74.-4.76., 4.82.-4.86.) Arra is láthattunk példát, hogy a tömeges kísérletek tapasztalatai hogyan alapozzák meg a bizonyítást, annak lényegi lépésének előrevetítésével (4.77.). Láthattuk, hogyan használhatjuk a számítógépet alkotó jelleggel, egy-egy egyszerú, s hatékonyan módosítható kód segítségével számítások elvégzésére (4.88., 4.93., 4.97.). A feladatok megoldását továbbra is a (számítógépes) tanulói felfedezéseknek rendeltük alá. Vizuális reprezentációink használatával (4.4.4.) lehetôvé vált a szigetrendszerek korábban megismert szerkezetének összekapcsolása jelenlegi célunkkal. A probléma összetettsége okán kénytelenek voltunk absztrakt tárgyalásba bonyolódni (4.104.-4.113.), a lehetôségekhez képest azonban igyekeztünk ezt is elôzetes felfedezésekkel felpuhítani, megalapozni. A tanulói kísérleteket szem elôtt tartva bevezettük a vágás, félsziget és a szigetrendszer kiegészített gráfjának fogalmát is.

\subsection{Szigetek korlátozott magassággal}

A fentiekben egy ismert tétel bizonyításához vezetô utat mutattunk be. A fenti problémakör azonban számos egyéb kérdést is felvet, ezek jórésze nyitott. Fontos, hogy diákjaink számára meg nem oldott problémákat is felvessünk. Ekkor talán nem fogják azt hinni, hogy egy matematikus nem tesz mást, mint „egész nap a Pitagorasz-tétellel számol”. Arra is láthattunk példát, hogyan lehet „úgy tenni”, mintha egy probléma új, megoldatlan volna. Miután azonban megoldottuk, s eláruljuk diákjainknak, hogy valójában egy ismert eredményt alkottunk meg újra, csalódottságuk érthetô lesz. Fontos tehát, hogy valódi nyitott kérdések is elókerüljenek, olyanok, amik ismertek, legendásak (Goldbach-sejtés, Riemann-hipotézis), s olyanok is, melyekkel mi magunk találkoztunk kísérleteink során. Az alábbiakban erre mutatunk példát.

\subsubsection{Bevezetés}

A fentiekben szigeteink magasságát nem korlátoztuk. A felhasznált magasságértékek tetszôlegesen nagyok lehettek. A következókben azt vizsgáljuk, hogyan változik a szigetek maximális száma, ha a magasság(függvény) korlátos. Itt tehát a maximális szigetszám nem csak a rács méretétôl, hanem a felhasználható maximális magasságtól, $h$-tól is függ. Erre vonatkozó kísérleteket is végeztünk már például a 4.34.-4.37. feladatok és a 4.46.-4.49. feladatok keretein belül.

Azt tudjuk, hogy ha $h \geq\left\lceil\log _{2}(m+1)\right\rceil+\left\lceil\log _{2}(n+1)\right\rceil-1$, akkor tudunk maximális számú szigetet kreálni az $m \times n$-es rácson [73]. De azt, hogy egy adott $h$ magasság esetén mennyi a legfeljebb $h$ magassággal az $m \times n$-es rácson előállítható szigetek száma, 
teljes egészében még nem sikerült megválaszolni. Részeredmények persze vannak, s ezeket mi magunk is felfedezhetjük. Itt is, a fejezet teljes egészének tárgyalása során folyamatosan használhatjuk a 4.3.6. fejezet Mathematica játékát. A korlátos magasságú szigetrendszerekrôl bővebben olvashatuk a szerzô $[72,112]$ cikkeiben (Eszter K. Horváth, Attila Máder, Andreja Tepavčević. One-dimensional Czédli-type Islands, The College Mathematical Journal, 42(5), 374-378, 2011., Attila Máder, Géza Makay. The maximum number of rectangular islands, The Teaching of Mathematics, 14(1), 31-44, 2011.).

\subsubsection{Már ismert eredmények, $h=1,2$}

A témakör nem is teljesen új, számos ide is tartozó eredményt már korábban megalkottunk. A következôkben ezek közül elevenítjük fel a legfontosabbakat.

4.116. Megjegyzés. Minden új témakör tárgyalása során fontos, hogy azt valamilyen módon kössük a korábban tanultakhoz. Ez itt, hála korábbi eredményeinknek, egyszerüen megtehetô.

4.117. Feladat. Hány szigetünk lehet legfeljebb az $m \times n$-es rácson, ha a maximális szigetmagasság $h=1$ ? (Gondoljunk a 4.46. feladatra!)

Megoldás. Ebben az esetben mindig pontosan egy szigetünk van, a fôsziget.

4.118. Feladat. Hány szigetünk lehet legfeljebb az $m \times n$-es rácson, ha a maximális szigetmagasság $h=2$ ? (Gondoljunk a 4.49. feladatra!)

Megoldás. Leghatékonyabban az egység területú, 2 magas mezók alkotnak szigetet. Ekkor a szigetek maximális száma $\left\lceil\frac{n}{2}\right\rceil \cdot\left\lceil\frac{m}{2}\right\rceil+1$.

Hasonló, egyszerú meggondolások azonban nem tehetôk, ha $h \geq 3$. Érdemes tehát egy-egy jól kezelhetô speciális eset vizsgálatával folytatnunk.

\subsubsection{Speciális esetek, az $1 \times n$-es rács}

4.119. Feladat. Legfeljebb hány szigetünk lehet az $1 \times n$-es rácson, ha $h=3$ ?

Megoldás. Ha $n=1,2, \ldots$ akkor rendre a következőt kapjuk a szigetek maximális számára: 1, 2, 3, 4, 5, 6, 7, 7, 8, 9, 10, 10, 11, 12, 13, 13, 14, 15, 16, 16 ... Ezekre az értékekre a korábban már használt OEIS a következô választ adja: I am sorry, but the terms do not match anything in the table. 
Kísérleteink ezen formája ezúttal nem járt sikerrel. Vizsgáljunk hát meg a szigeteink száma mellett egy-egy maximális szigetszámot adó konkrét konstrukciót is. Ez az elsố néhány esetben történhet kézzel, papíron, de írhatunk rá egy egyszerú programot is. Az világos, hogy a „brute force” technika most nem múködik, nem tudjuk végigszámoltatni programunk segítségével a számítógéppel az összes lehetséges kitöltést, hiszen ez már $h=3, n=10$ estén is $h^{n}=3^{10}=59049$ eset, míg ha $n=30$, akkor $h^{n}=3^{30} \approx 2 \cdot 10^{14}$. Felfedezéseinkkel azonban a számítógép munkáját is segíthetjük.

4.120. Megjegyzés. Felfedezéseink nem csak arra jók tehát, hogy segítségükkel egy kész eljárást használni tudjunk, hanem arra is, hogy egyáltalán lehetôvé tegyük a probléma számítógéppel történô megközelítését. Ezzel a felfedezések újabb szintjét mutattuk meg.

Azt már a korábbiakból is tudjuk, hogy az 1 szükségképpen felbukkan mezőink magasságai között. Ha ugyanis nincs 1 magas mezônk, akkor az összes mezô magasságát egyszerre, egyesével csökkenthetjük mindaddig, amíg 1 magas mezônk nem lesz, s közben a szigeteink száma nem változik. Ha viszont van 1 magas mezônk, egy rekurzív eljárás segítségével nagyságrendekkel csökkenthetjük a végigszámolandó esetek számát. Az informatikában ezt dinamikus programozásnak hívják. A $h=3, n=2,3, \ldots, 20$ eseteket az alábbiakban foglaltuk táblázatba.

$\begin{array}{rlr}n & \text { egy optimális szigetrendszer } & \text { a szigetek száma } \\ 2 & 1,2 & 2 \\ 3 & 1,2,3 & 3 \\ 4 & 1,3,2,3 & 4 \\ 5 & 2,1,3,2,3 & 5 \\ 6 & 2,3,1,3,2,3 & 6 \\ 7 & 3,2,3,1,3,2,3 & 7 \\ 8 & 1,3,2,3,1,3,2,3 & 7 \\ 9 & 2,1,3,2,3,1,3,2,3 & 8 \\ 10 & 2,3,1,3,2,3,1,3,2,3 & 9 \\ 11 & 3,2,3,1,3,2,3,1,3,2,3 & 10 \\ 12 & 1,3,2,3,1,3,2,3,1,3,2,3 & 11 \\ 13 & 2,1,3,2,3,1,3,2,3,1,3,2,3 & 13 \\ 14 & 2,3,1,3,2,3,1,3,2,3,1,3,2,3 & 13 \\ 15 & 3,2,3,1,3,2,3,1,3,2,3,1,3,2,3 & 14 \\ 16 & 1,3,2,3,1,3,2,3,1,3,2,3,1,3,2,3 & 16 \\ 17 & 2,1,3,2,3,1,3,2,3,1,3,2,3,1,3,2,3 & 16 \\ 18 & 2,3,1,3,2,3,1,3,2,3,1,3,2,3,1,3,2,3 & \\ 19 & 3,2,3,1,3,2,3,1,3,2,3,1,3,2,3,1,3,2,3 & \\ 20 & 1,3,2,3,1,3,2,3,1,3,2,3,1,3,2,3,1,3,2,3 & \end{array}$

4.59. ábra. Szigetek korlátozott magassággal, $h=3, n=2,3, \ldots, 20$ 
A fenti esetekből felfedezhetjük az optimális konfigurációk szerkezetét, és az általuk szolgáltatott maximális szigetszámot is. Programunk persze más $n, h$ párokra is futtatható; s még $h=10, n=1000$ esetén is kevesebb mint egy másodperc alatt lefut. Számos, maximális számú szigetet adó konkrét konstrukció vizsgálata után a következő sejtésekhez juthatunk.

4.121. Sejtés. Maximális számú szigetet tudunk kreálni az $1 \times n$-es rácson az $1,2,3$ magasságok felhasználásával a következô módon: a rács elsô mezôjétól kezdődően tegyünk minden második mezőre 3-as magasságot. Az üresen maradt mezőket figyelve az elsôtôl kezdődően tegyünk minden másodikra 2 magasságértéket, majd legvégül az üresen maradt cellákat töltsük fel egyesekkel.

4.122. Sejtés. A fenti eljárással keletkező szigetek száma maximális és:

$$
I_{3}(n)=n+1-\left[\frac{n}{4}\right]^{+}
$$

ahol $[\cdot]^{+}=\max \{1,\lfloor\cdot\rfloor\}$

4.123. Megjegyzés. A fenti jelölés kissé idegenül hathat, mégis ez a legegyszerúbb módja a sejtésünk formulába öntésének.

Következô feladatunk természetesen most is eredményünk általánosítása. Programunk más $h$ értékekre vonatkozó futtatásából megszülethetnek az általános esetre vonatkozó következő sejtéseink is.

4.124. Sejtés. Maximális számú szigetet tudunk kreálni az $1 \times n$-es rácson az $1,2, \ldots, h$ magasságok felhasználásával a következô módon: a rács elsô mezőjétôl kezdődốn tegyünk minden második mezôre $h$ magasságot. Az üresen maradt mezôket figyelve, az elsôtôl kezdődően tegyünk minden másodikra $h-1$ magasságértéket, és így tovább, egészen $h=2$-ig, majd legvégül az üresen maradt cellákat töltsük fel egyesekkel.

4.125. Sejtés. A fenti eljárással keletkezô szigetek száma maximális és:

$$
I_{h}(n)=n+1-\left[\frac{n}{2^{h-1}}\right]^{+} .
$$

4.126. Megjegyzés. A fenti sejtések közül elég csak az utolsót bizonyítani, hiszen az a korábbiak általánosításának is tekinthetô. Mivel a bizonyítás túl hosszú, s fóleg technikai, ezért azt itt most nem részletezzük. Annyit azonban érdemes megemlíteni, hogy kettôs indukcióval dolgozik, egy $n$, illetve egy $h$ szerintivel. A bizonyítás több változatban is megtalálható a szerzô [72] és [111] cikkeiben.

A továbbiakban a két, még ismert speciális eset vizsgálatával foglalkozunk. 


\subsubsection{Speciális esetek, a $2 \times n$-es rács}

4.127. Feladat. A 4.3.6. fejezet Mathematica animációját felhasználva próbáljunk meg maximális számú szigetet kreálni a $2 \times 2,2 \times 3, \ldots$ méretú rácsokon, az 1,2,3 magasságértékek felhasználásával. Mit tapasztalunk?

Számos kísérlet után, a korábbi, vágásos konstrukciók szem elôtt tartásával kialakulhat bennünk a sejtés az optimális konfigurációra vonatkozóan. Ezt természetesen további kérdésekkel segíthetjük is. Ebben a helyzetben különösen fontos, hogy a tanár maradjon meg a katalizátor szerepénél. A vegyük észre, hogy típusú továbblendítés helyett érje el, hogy a diákok tényleg maguk vegyék észre azokat a tényeket, melyek felé terelni próbáljuk óket. Ezt könnyen elérhetjük, ha a vizsgált problémát több kisebb, gyorsabban megválaszolható részproblémára bontjuk. Az alábbiakban erre láthatunk példát.

4.128. Feladat. Mit mondhatunk a 2 magas mezôt tartalmazó szigetekről?

Megoldás. Egyszerúen látható, hogy ezen szigetek $1 \times k$ vagy $2 \times k$ alakúak.

4.129. Feladat. A fentiekben meghatározott típusú szigetek közül melyik fordulhat elô egy optimális konfigurációban?

Megoldás. A 2 magas mezôt tartalmazó $1 \times k$ alakú szigetek nem optimálisak. Ha egy ilyen sziget fordul elô a rácsban, akkor a másik sor ezen szigettel szomszédos mezôinek magassága szükségképpen 1.

\begin{tabular}{|l|l|l|}
\hline 3 & 2 & 3 \\
\hline 1 & 1 & 1 \\
\hline
\end{tabular}

4.60. ábra. $1 \times 3$-as sziget a $2 \times 3$-a rácson

Ekkor viszont a jelenlegi felsô sort megismételve, majd itt a legmagasabb mezók magasságát 1-gyel megnövelve a szigetek száma nô.

\begin{tabular}{|l|l|l|}
\hline 3 & 2 & 3 \\
\hline 4 & 2 & 4 \\
\hline
\end{tabular}

4.61. ábra. A megváltoztatott tábla, több sziget 
Végül csökkentve eggyel minden mezô magasságát, a szigetek száma nem változik és minden mezô magassága legfeljebb 3 lesz.

\begin{tabular}{|l|l|l|}
\hline 2 & 1 & 2 \\
\hline 3 & 1 & 3 \\
\hline
\end{tabular}

4.62. ábra. A megváltoztatott tábla, több sziget $h=3$ korláttal

Ekkor viszont a 2 magas mezőt tartalmazó sziget $2 \times k$ alakú.

Az így kapott konstrukció beépíthető korábbi észrevételeink sorába.

4.130. Feladat. Mire emlékeztet ez minket?

Megoldás. Az $2 \times n$-es rácsnál felbukkanó vágásra.

4.131. Feladat. Mit állíthatunk a fenti észrevételünk segítségével?

Megoldás. Egy optimális konfigurációban a 2 magas mezóket tartalmazó szigeteink csak $2 \times k$ alakúak lehetnek. Ezek csak akkor optimálisak, ha $k=1$. Ez azt jelenti, hogy a rácsban szükségképpen van 2 magas függóleges vágás, hiszen épp a 2 magas mezóket tartalmazó $2 \times 1$-es részek funkcionálnak vágásként. Ez alapján rekurzió felállítására nyílik lehetőségünk. Ehhez a felfedezéshez segíthet minket hozzá a következô ábra.

\begin{tabular}{|l|l|l|l|l|l|l|}
\hline 3 & 2 & 3 & 1 & 3 & 2 & 3 \\
\hline 4 & 2 & 4 & 1 & 4 & 2 & 4 \\
\hline
\end{tabular}

4.63. ábra. Egy optimális konfiguráció

4.132. Feladat. Milyen transzformáció bújik meg a fenti elrendezésben?

Megoldás. Egyfajta tengelyes tükrözés. Alkossunk maximális számú szigetet először a legnagyobb magasságértékeink (ezúttal 3 és 4) segítségével elôször az $1 \times 2$-es rácson. Most, ha még egy magasságértékünk van (2), akkor ezen rács egy 2 magas vágásra való tükrözésével egy nagyobb rács optimális kitöltését érhetjük el, azonos magasságok segítségével. 
Mivel még egy felhasználatlan magasságunk van, most egy 1 magas vágásra való tükrözéssel ismét növelni tudjuk az optimálisan kitöltött rács méretét, azonos maximális magasság mellett.

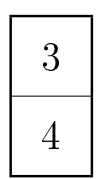

(a)

\begin{tabular}{|l|l|}
\hline 3 & 2 \\
\hline 4 & 2 \\
\hline
\end{tabular}

(b)

\begin{tabular}{|l|l|l|}
\hline 3 & 2 & 3 \\
\hline 4 & 2 & 4 \\
\hline
\end{tabular}

(c)

\begin{tabular}{|l|l|l|l|}
\hline 3 & 2 & 3 & 1 \\
\hline 4 & 2 & 4 & 1 \\
\hline
\end{tabular}

(d)

\begin{tabular}{|l|l|l|l|l|l|l|}
\hline 3 & 2 & 3 & 1 & 3 & 2 & 3 \\
\hline 4 & 2 & 4 & 1 & 4 & 2 & 4 \\
\hline
\end{tabular}

(e)

4.64. ábra. Tükrözéssel növelt világ

A fenti észrevétel segítségével megalkotható a következő tétel, melyet a bizonyítás technikai nehézségei, és a keretek szúkössége okán ezúttal sem részletezünk. A bizonyítás megtalálható a szerző [111] cikkében.

4.133. Tétel. Az $1,2, \ldots, h(h \geq 3)$, magasságok segítségével a $2 \times n$-es rácson létrehozható szigetek maximális száma:

$$
I_{h}(n)=\left\lfloor\frac{3 n+1}{2}\right\rfloor+1-\left[\frac{n}{2^{h-2}}\right]^{+} .
$$

4.134. Megjegyzés. A fenti formulát alaposabban szemügyre véve észrevehetjük abban a korlátlan esetben meghatározott maximumot. Ez a $2 \times n$-es rács esetében $\left\lfloor\frac{3 n+1}{2}\right\rfloor$. Eredményünk tehát azt jelenti, hogy korlátos magassággal legfeljebb ennél $\left[\frac{n}{2^{h-2}}\right]^{+}-1$ el kevesebb sziget hozható létre. Hasonló észrevétel természetesen az $1 \times n$-es rács esetén is fennáll (4.125. sejtés), de ott még ez a formulából, annak egyszerúsége miatt, nem volt azonnal észrevehetô.

A fenti megjegyzés egy nagyon fontos kapcsolatot tár fel a korlátos és korlátlan magassággokkal dolgozó esetek között.

\subsubsection{Speciális esetek, a $3 \times n$-es rács}

A $3 \times n$-es rács vizsgálatakor már egy jóval nehezebb problémával találjuk magunkat szemben. A kezdeti megközelítés persze nem változik.

4.135. Feladat. A 4.3.6. fejezet Mathematica animációját felhasználva próbáljunk meg maximális számú szigetet kreálni a $3 \times 3,3 \times 4, \ldots$ méretú rácsokon, az 1,2,3 magasságértékek felhasználásával. Mit tapasztalunk? 
A korábbiak mintájára itt is a 2 magas mezóket tartalmazó szigetek karakterizálásával érdemes felfedezéseinket kezdeni.

4.136. Feladat. Mit mondhatunk a 2 magas mezôt tartalmazó szigetekrôl?

Megoldás. A korábbiakkal analóg módon látható, hogy azok nem lehetnek $2 \times k$ alakúak.

4.137. Feladat. A 4.3.6. fejezet Mathematica játékának segítségével keressünk optimális konfigurációt a $3 \times 4$-es rácson, $h=4$ esetben, s próbáljuk meg azt az $1 \times n$-es és a $2 \times n$-es rácsnál tapasztalt vágások segítségével is létrehozni.

Megoldás. Egy lehetséges maximális szigetrendszer például a következő.

\begin{tabular}{|l|l|l|l|}
\hline 4 & 3 & 1 & 3 \\
\hline 2 & 2 & 1 & 2 \\
\hline 4 & 3 & 1 & 3 \\
\hline
\end{tabular}

4.65. ábra. Vágások a $3 \times 4$-es rácson

Számos kísérlet után, a felfedezett vágások segítségével rekurzió írható fel, mely a következô tételhez vezet. (A bizonyítás megtalálható a szerzô [111] cikkében.)

4.138. Tétel. Az $1,2, \ldots, h(h \geq 3)$, magasságok segítségével a $3 \times n$-es rácson létrehozható szigetek maximális száma:

$$
I_{h}(n)=2 n+2-\left[\frac{n}{2^{h-2}}\right]^{+} .
$$

4.139. Megjegyzés. A 4.134. megjegyzéshez hasonlóan itt is megállapítható, hogy az abszolút maximumhoz $(2 n+1)$ képest itt $\left[\frac{n}{2^{h-2}}\right]^{+}-1$-el kevesebb sziget hozható létre. 


\subsubsection{Speciális esetek, a $4 \times 4$-es rács problémája}

Ezek után a következô eset a $4 \times 4$-es rács problémája $h=3$ esetén. Egy optimális esetet mutat a következô ábra.

\begin{tabular}{|l|l|l|l|}
\hline 2 & 1 & 2 & 3 \\
\hline 3 & 1 & 1 & 1 \\
\hline 1 & 1 & 1 & 2 \\
\hline 2 & 3 & 1 & 3 \\
\hline
\end{tabular}

4.66. ábra. Probléma a $4 \times 4$-es rácson

Jelen esetben 9 szigetünk van. A fố különbség a korábbiakhoz képest az, hogy ez nem hozható létre az eddig sikerrel alkalmazott vágásos technika segítségével. Szimmetria okoknál fogva ugyanis alapvetően egy helyen tudjuk vágni rácsunkat. Ezt mutatja a következô ábra.

\begin{tabular}{|l|l|l|l|}
\hline & 1 & & \\
\hline & 1 & & \\
\hline & 1 & & \\
\hline & 1 & & \\
\hline
\end{tabular}

4.67. ábra. Vágás a $4 \times 4$-es rácson

Ezen a rácson viszont a korábbiak (4.6.3., 4.6.4. fejezet) felhasználásával könnyen látható módon csak 8 szigetet tudunk létrehozni. Egy lehetséges kitöltést mutat a következô ábra.

\begin{tabular}{|l|l|l|l|}
\hline 2 & 1 & 2 & 3 \\
\hline 3 & 1 & 1 & 1 \\
\hline 1 & 1 & 1 & 2 \\
\hline 2 & 1 & 1 & 3 \\
\hline
\end{tabular}

4.68. ábra. Vágás és szigetek a $4 \times 4$-es rácson

A továbbiakban a feladatunk tulajdonképpen téglalapok téglalapra történô, optimális lefedést biztosító elhelyezése. A probléma nehéz, NP-teljes, a témakör kutatása jelenleg is ezen a ponton tart. 


\subsubsection{Módszertani összefoglaló}

A fejezetben megvizsgáltuk különbözô speciális rácsokon a szigetrendszerek maximális elemszámát, korlátozott magasságfüggvény esetén. Számítógépes felfedezéseink forrása a korábbiakban már megismert 4.3.6. Mathematica játék volt. A témakörhöz kapcsolódó, már ismert speciális esetek (4.117.-4.118.) vizsgálata után megtapasztalhattuk, milyen, ha meglévő eszközeinkkel nem tudunk választ találni kérdésünkre (4.119.). Ezzel eljutottunk a felhasználói ismereteket is csak minimálisan igénylô alkalmazások használatától a saját program létrehozásáig. Saját programunk segítségével megoldottuk problémánkat az $1 \times n$-es rácson (4.122.). Az itt szerzett tapasztalatok alkotó jellegú felhasználásával, a tanulói felfedezéseket a $2 \times n$-es és a $3 \times n$-es eset megoldására irányítottuk (4.127.-4.138.). A fejezetet egy máig nyitott problémával zártuk (4.6.6.), a probléma gyökerének és nehézségi szintjének megvilágításával.

A dolgozatban felhasznált fontosabb programok, alkalmazások, demonstrációk, játékok, animációk megtalálhatók a CD mellékleten. 


\section{Összefoglalás}

A dolgozat témája az experimental mathematics néven ismertté vált új tudományos szemlélet oktatásra történő adaptálási lehetőségének bemutatása, összekapcsolván mindezt a felfedeztetô ismeretszerzéssel.

Az értekezés a szerző következő publikációin alapul:

- Eszter K. Horváth, Attila Máder, Andreja Tepavčević. One-dimensional Czédlitype Islands, The College Mathematical Journal, 42(5), 374-378, 2011.

- Attila Máder. Heads or Tails Gambling - What Can Be Learned about Probability?, Teaching Mathematics and Computer Science, 6(1), 15-41, 2008.

- Attila Máder, Róbert Vajda. Elementary Approaches to the Teaching of the Combinatorial Problem of Rectangular Islands, International Journal of Computers for Mathematical Learning, 15(3), 267-281, 2010.

- Attila Máder, Géza Makay. The maximum number of rectangular islands, The Teaching of Mathematics, 14(1), 31-44, 2011.

- Attila Máder. The Use of Experimental Mathematics in the Classroom, Interesting Mathematical Problems in Sciences and Everyday Life, 2011.

www.model.u-szeged.hu

Érintőlegesen a következô publikációból is merítünk:

- Máder Attila. A „specmat” 40 éve a Ságváriban I., A matematika tanítása, 17(4), 13-21, 2009.

Az elsô fejezetben röviden áttekintjük a magyar középiskolai matematikaoktatás helyzetét a Varga Tamás-féle tananyagreformtól ([26, 107]) kezdődően a napjainkban felmerülő problémákig. Kitérünk a PISA és TIMSS mérések viszontagságaira és elemezzük a mérések eredményeit. A XXI. században az ismeretelsajátítás szükségességét bizonyos kompetenciák megszerzésének fontossága váltotta fel, ezért a korábbi tantervi alapú, tartalmi elemekre összpontosító mérések mellett megjelentek a kompetencia alapú mérések is. A kompetencia, valamint a matematikai kompetencia fogalmának több oldalról történô megközelítése után részletesen tárgyaljuk az Országos 
kompetenciamérés eredményeit, hatásait, ellentmondásosságait [66]. Az új típusú tudásszemléletnek, illetve a megjelenő és egyre markánsabbá váló társadalmi igényeknek megfelelni kívánó új utak - mint a matematikai modellezés és a valóságközeli matematika $([4,102,50])$ - áttekintése után elemezzük a jelenlegi, válságosnak mondható helyzet okait.

A második fejezetben bemutatjuk a kísérleti matematika mibenlétét. A számítógépek fejlődésével és elterjedésével lehetôvé vált kísérletek nagy számú, gyors és hatékony elvégzése, azonnali kiértékelése; teret nyitva egy új matematikai szemlélet kialakulásának. Egyáltalán nem számítógéppel segített matematikáról van szó, sokkal inkább a számítógéppel megalkotott matematikáról. Maga a problémafelvetés, és ezen át a definíciók, tételek, bizonyítások megalkotása mind-mind számítógéppel történik. A számítógépes kísérleti matematika Borwein által megalkotott módszertanának ([17, 18, 21]) elemzése után rövid történeti áttekintést adunk a terület fejlődéséról, az 1990-es években történô megjelenésétôl kezdve egészen napjainkig. Ezután részletesen áttekintjük a kísérleti matematika oktatásban történô alkalmazásának elméleti hátterét. Mindennek itthon már van hagyománya, hiszen azt, hogy a kísérleteknek megkerülhetetlen szerepük van a heurisztika segítésében, Pólya és Lakatos óta tudjuk [90, 136]. Pólya szerint a kísérletek jelentik a matematikai tudás legfóbb forrását, a kísérletek azok, melyek a megfelelő irányba terelik az intuíciót. Ugyanakkor a számítógépek fejlôdésével és elterjedésével lehetôségünk nyílik nagy mennyiségú számítás valamint kísérlet gyors és pontos elvégzésére, illetve ezek eredményeinek kiértékelésére, következtetések levonására. A számítógépek ezen innovatív módon történô, alkotó jellegú felhasználásával, a Borwein által elindított kutatási módszer oktatásra való adaptálásával, a Pólya György által szorgalmazott heurisztika és kísérletezés végre a megérdemelt mértékú szerepéhez juthat a tanításban. A (közép)iskolások számára kitúzött, természetesen felmerülô, de ugyanakkor kutató jellegú problémák vizsgálata során a számítógép nem csak a szemléltetésben, de a problémafelvetésében, a fogalmak kialakításában, a sejtések megfogalmazásán és tesztelésén keresztül pedig a matematikai alkotás teljes folyamatában is segítségünkre lehet. A kísérlet és az elmélet elválaszthatatlanok [112]. A tanulók maguk is felfedezôvé válhatnak és ez az egyik legfontosabb központi gondolat. A fejezet végén röviden elemezzük módszerünknek a bizonyítás fogalmára gyakorolt hatását [88].

A harmadik fejezetben több példán keresztül bemutatjuk, hogyan is múködnek a felfedezések a matematikaórán. A fejezet elsô részében felfedezéseinket még számítógépes segítség nélkül tesszük meg. Megmutatjuk, hogyan lehet egy egyszerú ábra segítségével múveleti tulajdonságokat, vagy algebrai azonosságokat felfedeztetni. Három különbözô animációt is mutatunk a háromszögek belsô szögeinek összegére vonatkozó tétel bizonyítására. A számítógép nélküli felfedezések bemutatását egy egyszerú, a problémát játszhatóvá, felfedezhetôvé tévô valószínúségi modell bemutatásával zárjuk [104]. Bemutatjuk, hogy a tanári irányítással végzett tömeges tanulói kísérletek segítségével lehetôvé válik a kollektív tapasztalatszerzés, bevezethetünk új fogalmakat. Az itt bemutatott módszerek alkalmasak nem csak egy adott probléma, de akár egy egész témakör tárgyalására, illetve egy-egy új terület automatikus, természetes 
bevezetésére is. A fejezet következô részében bemutatjuk, hogyan változik meg a tanárok szerepe az információs társadalom által támasztott igényeknek való megfelelési kényszer hatása alatt [38]. Elemezzük, hogy a modern technikai eszközök használatában csak botladozva haladó tanárok hogyan segíthetik az ezen eszközöket organikusan használó digitális bennszülötteket a múveltség egyik új fokmérôje, a digitális írástudás elérésében. Vizsgáljuk a kérdések, a sejtések, és a számítógépek szerepét a számítógéppel segített felfedeztetô oktatásban. A fejezet harmadik szakasza a számítógép eszközszintú felhasználásával kivitelezhetô kísérletek bemutatásával foglalkozik. Többségében az interneten bárki által elérhető egyszerû alkalmazások, weblapok, animációk segítségével helyezünk új nézôpontba már tárgyalt kérdéseket, illetve hozunk testközelbe korábban elérhetetlen problémákat [124, 169]. A fejezetet a számítógépek alkotó jellegú felhasználási lehetôségeinek bemutatásával zárjuk. Néhány, a dolgozatban is használt, valamint az oktatásban is kiválóan alkalmazható szoftver bemutatása után bemutatjuk, hogyan tárgyalható a Thalész-tétel, a trigonometrikus azonosságok, a szintetikus geometria, vagy akár az analízis témaköre egy-egy alkalmazás segítségével könnyedén, a digitális bennszülöttek számára is felfedezhetô módon [59, 5, 12, 13].

A dolgozat utolsó fejezetében kísérletet teszünk a korábbiakban részletezett módszertani elvek egy konkrét, élő példán keresztül történô komplex reprezentálására. A tanulói felfedezéseket mindvégig szem előtt tartva, ahol csak lehet, egymásra épülő feladatok sorozatán keresztül jutunk el eredményeinkhez [110]. Egy rövid történeti áttekintés után feladatokon keresztül felépítjük a sziget fogalmát. Az önálló felfedezést segítô, tudatos tanári munkával irányított feladatokkal absztraháljuk a sziget fogalmát igazolván, hogy felfedezésekkel nem csak a sejtések, de a fogalmak szintjén is eredményes alkotó munka végezhető. A fogalom kialakításához egy Mathematica animációt is használunk. Az alkalmazás segítségével a tanulók kísérletek tucatjait végezhetik, akár közösen órán, akár otthon egyedül. A számítógép segítségével szerzett tapasztalatok segítenek a fogalmak gyors és hatékony kialakításában, elmélyítésében. A következô részben a szigetrendszerek szerkezetét tárjuk fel. A minimális és maximális szigetek fogalmának bevezetése mellett megalkotjuk a szigetrendszer gráfját, és vizsgáljuk a gráfok és a szigetek kapcsolatát, egy újabb Mathematica animáció használatával. A következô szakaszban célunk az $m \times n$-es rácson elhelyezhetô szigetek maximális számának meghatározása abban az esetben, ha a magasságfüggvény nem korlátos. E feladat elsố megközelítésre túl bonyolult, ezért egy-egy speciális eset vizsgálatával kezdünk. A korábban bemutatott interaktív Mathematica animáció segítségével nem csak, hogy sejtéseket fogalmazunk meg, de a bizonyítás alapgondolatát is megtaláljuk az $1 \times n$ es rács esetében. Az itt felfedezett vágásos technika segítségével sejtést fogalmazunk meg a $2 \times n$-es rácson elhelyezhetô szigetek maximális számára vonatkozó alsó korlátot illetően, s ezt be is bizonyítjuk. Ezzel a számítógéppel segített bizonyítással a számítógép alkotó jellegú felhasználásának egy újabb szintje tárul fel. Módszerünk általánosításával az $m \times n$-es rácsra vonatkozó alsó korlátot is megtaláljuk. Az alsó korlát megtalálása után a szigetrendszerek gráfjának segítségével egy felsố korlát keresésébe fogtunk [11]. A korábban már eredményesen használt Mathematica demonstráció segítségével elemezzük a vízszint emelkedésének a szigetekre gyakorolt hatását. Az egy 
gráfelméleti tétel segítségével megtalált felsô korlát megegyezik a korábban megtalált alsó korláttal, így a fejezet fő eredményeként megkaptuk az $m \times n$-es rácson elhelyezhetô szigetek maximális számát. Ezek után fogunk az $m \times n$-es rácson korlátozott magassággal elhelyezhetô szigetek maximális számának vizsgálatába. A korábban felfedezett eredmények, a megtalált módszerek (vágásos technika) továbbfejlesztésével, valamint a számítógép felhasználásának legmagasabb szintjének elérésével, egy saját készítésû program segítségével meghatározzuk az $1 \times n, 2 \times n$ és $3 \times n$-es rácson legfeljebb $h$ magasság felhasználásával elérhetô maximális szigetszámot [72, 111]. A fejezet végén megmutatjuk, módszerünk miért nem múködik nagyobb rácsokra. 


\section{Summary}

The theme of this thesis is the possible adaptations of experimental mathematics combined with experimental learning in teaching.

The dissertation is based on the following papers of the author:

- Eszter K. Horváth, Attila Máder, Andreja Tepavčević. One-dimensional Czédlitype Islands, The College Mathematical Journal, 42(5), 374-378, 2011.

- Attila Máder. Heads or Tails Gambling - What Can Be Learned about Probability?, Teaching Mathematics and Computer Science, 6(1), 15-41, 2008.

- Attila Máder, Róbert Vajda. Elementary Approaches to the Teaching of the Combinatorial Problem of Rectangular Islands, International Journal of Computers for Mathematical Learning, 15(3), 267-281, 2010.

- Attila Máder, Géza Makay. The maximum number of rectangular islands, The Teaching of Mathematics, 14(1), 31-44, 2011.

- Attila Máder. The Use of Experimental Mathematics in the Classroom, Interesting Mathematical Problems in Sciences and Everyday Life, 2011.

www.model.u-szeged.hu

Additionally we have used the following publication as well:

- Máder Attila. A „specmat” 40 éve a Ságváriban I., A matematika tanítása, 17(4), 13-21, 2009

In the first section we briefly discuss the state of mathematics teaching in secondary schools from Tamás Varga's curriculum reform $([26,107])$ to the present days. We mention the problems of PISA and TIMSS surveys and examine their results. In the 21st century the skill based learning took over from the lexical knowledge based education and as a result competence based surveys have appeared beside curriculum based surveys. After the discussion of competencies and mathematical competency we show the results, consequences and the controversies of the National Competency Test [66]. Following this we discuss the new ways of teaching as mathematical modelling 
and functional mathematics which are more and more demanded by the new scientific approach and the continuously changing society expectations then we move on to analyse the present crucial situation $[4,102,50]$.

In the second section we are going to describe the experimental mathematics. The improvement and spread of computers have allowed to research quickly and efficiently, and to analyse great amount of data immediately which creates new environment for educational mathematic research. The problem identification, definitions, thesis and proofs are created with the help of computer. It is rather computer created than computer supported mathematics. We describe the methodology of computer supported experimental mathematics created by Borwein $([17,18,21])$ and briefly present the historical overview of this field starting from the 1990s to present days. Then we are going to examine the theoretical background of experimental mathematics in mathematics teaching, which is not new in our country. Since Pólya and Lakatos we know the crucial importance of experiments in helping heuristics [90, 136]. According to Pólya, experiments are the basic source of mathematical knowledge that drive the intuition in the correct direction. The improvement and spread of computers have made us able to make a lot of calculations and experiments quickly and punctually, and we can analyse the results and draw the consequences. By this creative and innovative way of computer usage the research method adaptation to education was started by Borwein while the heuristics was urged by György Pólya, and experiments finally might achieve their deserved ratio in education. When we examine realistic and experimental problems with students in secondary school, computers help not only in representation but also in define ing problems and creating concepts as well. Moreover, by making and testing conjectures, they help in the creation of mathematics. There is no theory without experiments [112]. Students can become explorers, and this is the most important idea. At the end of the section we analyse the influence of our new method to the definition of proof [88].

In the third section we show several examples of exploration in mathematics lessons. In the first part of the section we have our explorations without computers. We describe how a simple figure can be used for noticing characteristics of operations or algebraic identities. We show three animations for proof of the sum of the interior angles of triangles. The presentation of discoveries without computers ends with a simple, playfully probabilistic model [104]. We show how group experiments make the collective experience and the introduction of new concept possible. Methods showed here are suitable not only for a given problem but even for the automatic and natural discussion of a new topic or a whole field as well. In the next part of this section we summarize how the teachers' role changes as a result of the demand of the society [38]. We analyse how teachers who can hardly use modern equipment should help students who were born into the organic usage of these equipments with achieving one of the measures of new knowledge the digital literacy. We examine the roles of questions, hypothesis and computers in the computer supported exploratory teaching. The third part of the section is about the computer supported experiments. We mostly use simple applications, web pages and animations publically available on the Internet in order 
to find new prospect to earlier discussed questions and new ways to get closer to previously unachievable problems $[124,169]$. The section ends with the demonstration of creative ways of computer usage. After presenting the softwares used in the thesis and other useful alternatives we demonstrate how the Thales Theorem, trigonometrical identities, synthetic geometry or even the topic of analysis can be taught for digital aboriginals in explorational way using some applications [59, 5, 12, 13].

In the last section of the thesis we make an attempt to a complex representation of the previously discussed methodology through a concrete, real example. Keeping in mind the students' exploration and where it is possible, we use series of exercises build on each other [110]. After a short historical overview we are going to set up the concept of island through examples fostering self exploration. By these examples combined with teacher's supportive and conscious supervision we are able to create the concept of island which is suitable for further mathematical examination in different level of abstraction, proving that by explorations we can work efficiently not only on the level of hypothesis but on the level of concepts as well. To set up the concept we use a Mathematica animation. With the support of this application the students can carry out dozens of experiments together in the lesson or alone at home. The computer based experience help to create and understand the concept quickly and efficiently. In the next section we analyse the structure of the system of islands. Besides the introduction of the definition of minimal and maximal island we create the graph of island's system in addition to this we analyse the relationship between graphs and islands with another Mathematica animation. In the next section our aim is to find the maximal number of islands on a $m \times n$ sized board when the height function is not bounded. For the first sight this problem is too complex so we start with a special case. With the previously mentioned interactive Mathematica animation we not only create hypotheses but find the main idea of proof in case of $1 \times n$ sized board. Using discovered cutting technique we make conjectures for the lower bound of the number of the islands lying on a $2 \times n$ sized board and we prove the conjecture. The computer supported proof is a new potential of creative usage of computers. By generalizing our methodology we are able to find the lower bound related to $m \times n$ sized board. The determination of lower bounds is followed by the quest for an upper bound using the graphs of the systems of islands [11]. The previously used Mathematica demonstration is used to analyse the influence of the rise of the water level to the system of islands. The upper bound, which is found using the theorem of graph theory equals to the lower bound, determined earlier, so the main result of this chapter is the maximal number of islands lying on an $m \times n$ sized board. After this we start calculating the number of islands with bounded heights on an $m \times n$ sized board. Using the previous results, the improvement of the already found method (cutting technique), the highest involvement of a computer and using a self-developed program we determine the maximal number of islands which are at most $h$ height lying on a $1 \times n, 2 \times n, 3 \times n$ sized board [72, 111]. At the end of the section we explain why our method is not suitable for larger boards. 


\section{Köszönetnyilvánítás}

Köszönetet szeretnék mondani témavezetômnek, Dr. Kosztolányi Józsefnek a sok szakmai és személyes tanácsért, támogatásét. Köszönöm azt a sok segítséget és értékes útmutatást is, amit az elmúlt években kutatómunkám, illetve a disszertáció elkészítése során tőle kaptam.

Hálás köszönettel tartozom általános iskolai matematikatanáromnak, Szalainé Szunyi Klárának. Az ô szeretô gondoskodása, szakmai elkötelezettsége hatására szerettem meg a matematikát, $\mathrm{s}$ válaszottam ezt a pályát.

Köszönettel tartozom társszerzôimnek név szerint, K. Horváth Eszternek, Andreja Tepavčevićnek, Makay Gézának, Vajda Róbertnek. Nagy öröm volt együtt dolgozni velük, a közös munka rendkívül inspiráló volt, és rengeteget tanultam közben.

Köszönöm Nagy Dórának, Cseh Zsuzsannának és Guy Thomasnak az angol nyelvû részek összeállításában nyújtott segítségüket.

Hálás vagyok édesanyámnak, valamint Vaskó Marianna és Matos Zoltán barátomnak a kézirat többszöri gondos átolvasásáért, javításáért.

Külön köszönet illeti továbbá Lénárt Ivett és Szörényi Péter tanítványaimat a szigetek múvészi ábrázolásáért. 


\section{Tárgymutató}

aktív tanulói részvétel, 2, 29, 32, 34, 35, eEuropa, 44 43, 48, 92, $93 \quad$ Einstein, Albert, 1

AMS, 21

Erdôs Pál, 51, 52

antiderivált, 64

Euklidesz, 59

Appel, Kenneth, 21

aszinkron tanulás, 44

Euler 3D, 59

Autograph, 56, 60, 65

Experimental Mathematics, 21

experimental mathematics, 18, 22, 23, 129,

Banach-Tarski paradoxon, 30

Barwise, Jon, 21

bizonyosság, 25, 26, 34, 37, 59, 69, 70

Blum, Werner, 10, 11

Blum-modell, 11

Bolyai Intézet, 55, 71

Borwein, Jonathan, 21, 23, 46, 130

brute force, 121

133, 134, 141, 142, 148, 151

Földes István, 70

fa, 101, 115

Fajtlowicz, Siemion, 46

fedés, 99, 102

Fejes Tóth Gábor, 22

felfedezés, 2, 4, 24, 29, 30, 32-35, 39, 43$45,47-49,51,54,56,60-62,64-67$, 69, 70, 72, 79, 92, 101, 105, 108,

Cabri, 59

CECM, 21

Chu-Ching Huang, 58

Coolahan, John, 7

CooSpace, 43

COQS, 40, 41

Czédli Gábor, 71

$116,119,121,122,126,128,131$

Freudenthal Intézet, 12

Freudenthal, Hans, 12

gépi számábrázolás, 69

Gauss, 30, 32

GeoGebra, 55, 56, 59, 60, 62, 64, 67

Derive, 57

Devlin, Keith, 21

Dienes Zoltán, 22

digitális írástudás, 40, 131

digitális bennszülött, 42-44, 48, 54, 105, 150

digitális bevándorló, 42, 43

dinamikus geometriai szoftver, 56

dinamikus programozás, 121

DQME, 12

e-learning, 43, 44, 58

GeoGebra Intézet, 55

gráf, 98, 99, 101, 102, 104, 115

összefüggô, 101

irányított, 99

szigetrendszeré, 98-100, 103, 105, 114, 115,117

szigetrendszeré, kiegészített, 117-119

GrafEq, 59

Graffiti, 46

Graph, 59

háromszögszám, 33

Haken, Wolfgang, 21 
Hale, Thomas, 21

Hardy, G. H., 27

Hasse-diagram, 99

hatféle B, 43

Hatsell, Mark, 56

HEFOP, 8

heurisztika, 18, 22-24, 70, 105, 130

Hoffman, Paul, 50

Hohenwarter, Markus, 55

ICTMA, 10

IKT, 17, 40, 41

információrobbanás, 16, 40

integrál, 64, 65

határozatlan, 64

határozott, 64

mint a felsố határ függvénye, 64

intuíció, 19, 22-24, 29, 31, 33, 51, 73, 92, 105,130

IoT, 43

játékalapú tanulás, 42

játékos matematika, 2, 61

Jaffe, Arthur, 21

középvonal, 36

közoktatási törvény, 16

kétoldali közelítés módszere, 28, 31, 33, 39, 108,118

kód

prefixmentes, 71

kísérlet, 19, 20, 22, 23, 26, 29, 34-37, 40, $46,48,49,51,53-55,60,61,70$, $75,93,101,105,107,112,116,119$, 121,130

kísérleti matematika, 18, 22, 23

Kepler, 21

Kerettanterv, 13

kollektív tapasztalatszerzés, 40, 130

kompetencia, 6-8, 40

-mérés, 9

alapú oktatás, 8

funkcionális, 7

kulcs-, 7

matematikai, 8 komplex matematikatanítási kís., 1

komputer-algebrai rendszer, 54, 55, 75, 110

kutatásalapú tanulás/tanítás, 17, 43, 46

Lakatos Imre, 22, 24, 130

Leibniz, 29

LEMA, 10

Lengvárszky Zsolt, 71

levél, 102, 115

lifelong learning, 44

mértani sor, 38, 39

MACSYMA, 54

majoráns kritérium, 53

matematikai eszköztudás, 4, 9

matematikai múveltség, 2, 16

matematikai modellezés, 10

matematikai tudás, 4

Mathematica, 36, 49, 75, 91, 93, 104, 105, $108,110,112,113,116,120,123$, $125,126,128,152$

Maxima, 55

modell, 73, 99, 104

leíró, 11

matematikán belüli, 10, 11

normatív, 11

modellezési ciklus, 10

Monte Carlo-módszer, 51

Monty Hall-dilemma, 50, 51

Moodle, 43

négyszín sejtés, 21

Nagy József, 7

nagy számok törvénye, 51

NAT, 8, 16

New Math, 1

Newton-Leibniz formula, 64

Niss, Mogens, 8

OEIS, 47, 108, 109, 120

Oundle School, 56

Pálinkás József, 16

Pólya György, i, 4, 22-24, 27, 105, 112, 130 
permanencia-elv, 27, 28

Piaget, 32

PISA, 3-6, 10, 14

Poly, 59

Prensky, Marc, 42

primitív függvény, 64

problémamegoldó gondolkodás, 2, 24

proof without words, 25, 62

pure mathematics, 21, 29

Quinn, Frank, 21

rácspont, 114, 115, 117

részbenrendezett halmaz, 99

realisztikus matematika, 12,69

rekurzió, 110, 112, 124, 126

másodrendú lineáris, 112, 114

paraméteres, 113

reláció, 99

Savant, Marilyn vos, 50, 52

Selin, Steve, 50

SIBIS, 41

Simon, Herbert, 54

Skemp, Richard, 4

Skype, 44

spirális felépítés, $1,27,58$

Stirling-formula, 53

Sulinet, 48, 53

szórakoztató tanulás, 42

Szegedi Tudományegyetem, 43, 70

sziget, 71-77, 82, 86, 87, 89-96, 99, 102$105,108,109,112,114,116,120$, $121,123,126,127,131$

egydimenziós-, 70

fél-, 117-119

fó-, 74, 75, 85-87, 92, 95-98, 101, 102, $104,110,120$

magasság, 82

maximális, 96-98, 102

minimális, 96, 97, 102, 115, 117, 118

téglalap alakú, 71, 76

tómentes, 73

tetszőleges alakú, 74 szigetrendszer, 71, 79, 81, 83, 92-96, 98, 99, 101-105, 114-116

kanonikus reprezentáció, 80, 83, 84, $86,88,92,98,99,106,116$

maximális, 71, 92, 126

Szilassi Lajos, 59

szinkron tanulás, 44

szukcesszív approximáció módszere, 25

TÁMOP, 8

Taylor-polinom, 67-69

Taylor-sor, 68

teljes indukció, 25, 32, 33, 95, 102, 111, 112,122

Teller Ede, 40

Thalész-tétel, 37, 59

The Geometer's Sketchpad, 59

Thom, René, 28

Thruston, William P., 28

TIMSS, 3, 5

Ulam, Stanislaw, 51

vágás, 110, 112, 119, 124, 126, 127

Vázsonyi Endre, 51

valós számok múveleti axiómái, 31

valóságközeli matematika, 3

valószínúségi változó, 53

Varga Tamás, 1, 12

Venn-diagram, 48, 49

Virtual Learning Environment, 43

WebMathematics Interactive, 55, 57, 58

Wilder, Raymond Louis, 27

Wolfram Demonstrations Project, 49, 53, 91

Zeilberger, Doron, 18, 22 


\section{Ábrák jegyzéke}

1.1. A PISA 2006 és a TIMSS 2007 eredményeinek összehasonlítása matematikából . . . . . . . . . . . . . . . . . 5 5

1.2. A modellezési ciklus (PISA 2003) . . . . . . . . . . . . . . 10

1.3. A Blum-modell . . . . . . . . . . . . . . . . . . . . . . . . . 11

1.4. Informatikai eszközök használati gyakorisága a matematikaórákon .. . 13

1.5. Tanulásszervezési formák gyakorisága a matematikaórákon . . . . . . . 14

2.1. A kísérletek szerepe a tudományos felfedezésekben . . . . . . . . . . . . 20

3.1. Múveleti tulajdonságok: $(b+c) a=b a+c a \ldots \ldots$. . . . . . . . 30

3.2. $(a+b)^{2}=a^{2}+2 a b+b^{2} \ldots \ldots \ldots \ldots \ldots \ldots$

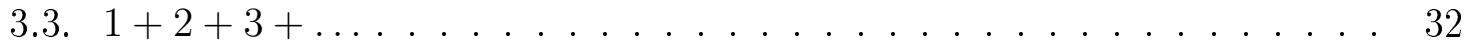

3.4. Felfedezés: A pozitív egészek összege és a téglalap fele . . . . . . . . . 32

3.5. Felfedezés: A pozitív egészek összege és a háromszögszámok . . . . . . . 33

3.6. Bizonyítás(?) - A háromszög belsô szögeinek összege I. . . . . . . . . . 34

3.7. Bizonyítás(?) - A háromszög belsố szögeinek összege II. . . . . . . . . . 35

3.8. Bizonyítás(?) - A háromszög belső szögeinek összege III. . . . . . . . . 36

3.9. Thalész-tétel - Bizonyosság vagy bizonyítás? . . . . . . . . . . . . 37

3.10. Dobás az elsố hatosig . . . . . . . . . . . . . . . . . . . . . . . . 38

3.11. Digitális írástudás - COQS index . . . . . . . . . . . . . . . . 41

3.12. $(A \cap B) \cup C=(A \cup C) \cap(B \cup C) \ldots \ldots \ldots \ldots . \ldots . \ldots$

3.13. Bizonyítás(?) - A háromszög belsố szögeinek összege IV. . . . . . . . . 50

3.14. A Monty Hall-dilemma . . . . . . . . . . . . . . . . . . . 51

3.15. A Monty Hall-dilemma és a Monte Carlo-módszer . . . . . . . . . . . . 51

3.16. Dilemma: Hogyan döntenénk? . . . . . . . . . . . . . . . . . . 52

3.17. A lusta pénztáros . . . . . . . . . . . . . . . . . . . . 53 
3.18. Autograph - Lassú ábrázolás: $\sin 2 x$ hol a következő zérushely? . . . . . 56

3.19. Derive - Integrálás lépésenként $-\int x^{2} \cdot e^{x} d x \ldots \ldots$. . . . . . . 57

3.20. WMI - Pillanatkép . . . . . . . . . . . . . . . 58

3.21. Thalész-tétel - Pillanatkép . . . . . . . . . . . . . . . . . . 59

3.22. Hol halad a pont...? . . . . . . . . . . . . . . . . . . . 60

3.23. ... az $y=-\cos x$ görbe mentén . . . . . . . . . . . . . . 61

3.24. A felfedezés: $-\cos x=\cos (x-\pi) \ldots \ldots$. . . . . . . . . . 61

3.25. A háromszögek hasonlóak . . . . . . . . . . . . . . . . . . 62

3.26. A képpontok által kifeszített négyszög . . . . . . . . . . . . . . 63

3.27. A beírt körök érintik egymást . . . . . . . . . . . . . . . . . . . . . . 64

3.28. Alsó és felsô összegek és a beosztás finomsága . . . . . . . . . . . . . . 65

3.29. Alsó és felső összegek és a határozott integrál . . . . . . . . . . . . . . 65

3.30. Készül a forgástest . . . . . . . . . . . . . . . . . . . . 66

3.31. A forgástest és jellemzői _ . . . . . . . . . . . . . . . . . 66

3.32. Felfedezések - a $\cos x$ és a Taylor-polinom. Hol és mennyire jó a közelítés? 67

3.33. Felfedezések - a $\cos x$ és a Taylor-polinom. Jó és kevésbé jó közelítések . 67

3.34. A $\cos x$ és a Taylor-polinom - Miért közelít? . . . . . . . . . . . . . . . 68

3.35. Taylor-polinom a 6 körül - jobb közelítés egy másik tartományon . . . . 68

3.36. Taylor-polinom - (Ugye) mennyire jól közelít? . . . . . . . . . . . . . . 69

4.1. Szigetek az $1 \times 7$-es rácson . . . . . . . . . . . . . . . . 70

4.2. Szigetek két dimenzióban . . . . . . . . . . . . . . . . . . . . 71

4.3. Mi a sziget? . . . . . . . . . . . . . . . . . . . . 72

4.4. Leegyszerúsített világunk . . . . . . . . . . . . . . . . . . . . . . . 73

4.5. Keressük meg a szigeteket! . . . . . . . . . . . . . . . . . . . . . . . . . 74

4.6. Szigetek tetszóleges alakkal . . . . . . . . . . . . . . . . . . . . 74

4.7. Szigetek tetszóleges alakkal . . . . . . . . . . . . . . . . . . . 74

4.8. Kis rács, sok sziget . . . . . . . . . . . . . . . . . . . . 75

4.9. Nagy rács, sok sziget $-m n$ sziget az $m \times n$-es rácson $\ldots \ldots$. . . . . 76

4.10. Szigetek absztrahálódása . . . . . . . . . . . . . . . . . . . 76

4.11. Keressük meg az összes (téglalap alakú) szigetet! . . . . . . . . . . . . . 78

4.12. A téglalap alakú szigetek . . . . . . . . . . . . . . . . . . . . 78

4.13. Adjuk meg a magasságokat! . . . . . . . . . . . . . . . . . . . . . . . 79 
4.14. A 4.17. feladat megoldásai . . . . . . . . . . . . . . . . . . . . . . 79

4.15. Magasságok másképp . . . . . . . . . . . . . . . . . . . . . . . 80

4.16. Magasságok csökkentése . . . . . . . . . . . . . . . . . . . 81

4.17. Minimális magasságok . . . . . . . . . . . . . . . . . . . 81

4.18. Szigetek és magasságaik _. . . . . . . . . . . . . . . . . 82

4.19. Szigetek és magasságaik _. . . . . . . . . . . . . . . . . . 83

4.20. 2 illetve 3 magas szigetek . . . . . . . . . . . . . . . . . . . . 83

4.21. Keressük a kanonikus reprezentánst! . . . . . . . . . . . . . . . . . . . 84

4.22. Szigetek kanonikus reprezentációja . . . . . . . . . . . . . . . . 84

4.23. Adjuk meg a magasságokat! . . . . . . . . . . . . . . . . . . . . 85

4.24. Megoldás, ha a magasság legfeljebb 1 . . . . . . . . . . . . . . . 85

4.25. Adjuk meg a magasságokat! . . . . . . . . . . . . . . . . . . . . 85

4.26. Megoldások, ha a magasság legfeljebb $2 \ldots$. . . . . . . . . . . . . . . . 86

4.27. Adjuk meg a magasságokat! . . . . . . . . . . . . . . . . . . . . 86

4.28. Megoldások, ha a magasság legfeljebb $4 \ldots \ldots$. . . . . . . . . . . 87

4.29. Egyenetlen talaj, csak a fôszigettel . . . . . . . . . . . . . . . 87

4.30. 2 sziget a $2 \times 3$-as rácson . . . . . . . . . . . . . . . . 88

4.31. Ellenpélda a 4.42. feladat állítására . . . . . . . . . . . . . . . . . . . . 88

4.32. 5 sziget a $2 \times 3$-as rácson . . . . . . . . . . . . . . . . . . . . . 89

4.33. 3 sziget a $2 \times 3$-as rácson . . . . . . . . . . . . . . . . . . . . 90

4.34. Szigetek a $6 \times 7$-es rácson, ha $h=2 \ldots \ldots$. . . . . . . . . . 90

4.35. Játék a szigetekkel Mathematicaban . . . . . . . . . . . . . . . . 91

4.36. Metszố szigetek . . . . . . . . . . . . . . . . . . . . . . . . . . 94

4.37. Minimális és maximális szigetek . . . . . . . . . . . . . . . . . . 96

4.38. Minimális és maximális szigetek . . . . . . . . . . . . . . . . . . . 97

4.39. Minimális és maximális szigetek . . . . . . . . . . . . . . . . . . . 97

4.40. Szigetek és gráfok . . . . . . . . . . . . . . . . . . . . . . . 98

4.41. Rajzoljuk fel a gráfokat! . . . . . . . . . . . . . . . . . . . . 100

4.42. Szigetrendszereink gráfjai . . . . . . . . . . . . . . . . . . . . 100

4.43. Adjunk meg szigetrendszereket! . . . . . . . . . . . . . . . . . . . 101

4.44. Gráfjaink szigetrendszerei . . . . . . . . . . . . . . . . . . 101

4.45. A minimális szigetek a levelek . . . . . . . . . . . . . . . . . . 102 
4.46. A maximális szigetek a gyökér fiai . . . . . . . . . . . . . . . . . 102

4.47. Gráfok és szigetek . . . . . . . . . . . . . . . . . . . . . 103

4.48. Szigetrendszerek és szerkezetük Mathematicaban . . . . . . . . . . . . . 104

4.49. Szigetek kis rácsokon . . . . . . . . . . . . . . . . 106

4.50. Szigetek - az elsô vágás ～. . . . . . . . . . . . . . . . . . . 106

4.51. Szigetek - a becslés éles . . . . . . . . . . . . . . . . 106

4.52. A 4.79 feladat megoldásai . . . . . . . . . . . . . . . . . . . 107

4.53. Vágás a $2 \times n$-es rácson _. . . . . . . . . . . . . . . . 110

4.54. Vágás az $m \times n$-es rácson . . . . . . . . . . . . . . . . . . 113

4.55. Rácspontok és minimális szigetek . . . . . . . . . . . . . . . . . 115

4.56. Változó szigetek ～. . . . . . . . . . . . . . . . . . . . 116

4.57. Félszigetek . . . . . . . . . . . . . . . . . . . . . . 117

4.58. Rácspontok és félszigetek . . . . . . . . . . . . . . . . . . . 117

4.59. Szigetek korlátozott magassággal, $h=3, n=2,3, \ldots, 20 \ldots \ldots$

4.60. $1 \times 3$-as sziget a $2 \times 3$-a rácson _ . . . . . . . . . . . . . . . 123

4.61. A megváltoztatott tábla, több sziget . . . . . . . . . . . . . . 123

4.62. A megváltoztatott tábla, több sziget $h=3$ korláttal . . . . . . . . . . . 124

4.63. Egy optimális konfiguráció . . . . . . . . . . . . . . . . . . . . . . . . . 124

4.64. Tükrözéssel növelt világ ． . . . . . . . . . . . . . . . . . . . . . . 125

4.65. Vágások a $3 \times 4$-es rácson . . . . . . . . . . . . . . . . 126

4.66. Probléma a $4 \times 4$-es rácson . . . . . . . . . . . . . . . . . . . . 127

4.67. Vágás a $4 \times 4$-es rácson . . . . . . . . . . . . . . . . . . 127

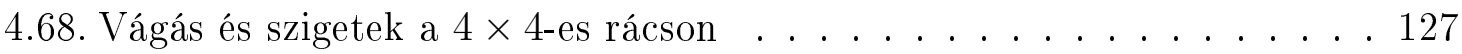




\section{Irodalomjegyzék}

[1] Steven C. Althoen, Joseph L. Brandell. Investigating Bricard's Proof of Morley's Theorem with The Geometer's Sketchpad, Mathematics Teacher, 102(9), 706$719,2009$.

[2] Ambrus András. A konkrét és vizuális reprezentációk használatának szükségessége az iskolai matematikaoktatásban, Képzés és gyakorlat, Konstantin Filozófus Egyetem, Nyitra, 19-32, 2008.

[3] Ambrus Gabriella. Hagyományos és problémaorientált feladatok kapcsolatának vizsgálata az iskolai gyakorlatban, A matematika tanítása, 15(1), 3-9, Szeged, 2007.

[4] Ambrus Gabriella, Vancsó Ödön. Modellezés az iskolai gyakorlatban, A matematika tanítása, 16(5), 3-11, Szeged, 2008.

[5] Autograph

www . autograph-math. com

[6] George E. Andrews. The Death of proof? Semi-Rigorous Mathematics? You've Got to Be Kidding!, The Mathematical Intelligencer 16(4), 16-18, 1994.

[7] Bonnie Averbach, Orin Chein. Problem Solving Through Recreational Mathematics, Dover Publications, New York, 2000.

[8] Béla Bajnok. An historical overview of the influence of technology on Mathematical competitions, History of Mathematics and Teaching of Mathematics, Szeged, 2010. május 20-22.

[9] Alain Baker. Experimental Mathematics, Erkenntnis 68(3), 331-344, 2008.

[10] Baldaváriné Juhász Éva, Mezőné Oszlánczi Ilona. Készüljünk a kompetenciamérésre!, Szövegértés és matematika, 6. évfolyam, Maxim Kiadó, Szeged, 2009.

[11] János Barát, Péter Hajnal, Eszter K. Horváth. Elementary proof techniques for the maximum number of islands, European Journal of Combinatorics, 32(2), 276-281, 2011. 
[12] C. N. Barton. Autograph Activities - Teacher Demonstrations for 16-19, Eastmond Publishing Ltd, Oundle, Peterborough, 2009.

[13] C. N. Barton. Autograph Activities - Student Investigations for 16-19, Eastmond Publishing Ltd, Oundle, Peterborough, 2009.

[14] Blénessy Gabriella. Kooperációs lehetôségek a matematika- és informatikaoktatás területén, A matematika tanítása, 17(2), 25-31, 2009.

[15] Werner Blum. Application and Modelling in Mathematics Education (Discussion Document (ICMI Study 14)), Educational Studies in Mathematics, 51, 149-171, 2002.

[16] Werner Blum, Gabriele Kaiser, Rita Borromeo Ferri, Gloria Stillman (szerk.). Trends in Teaching and Learning of Mathematical Modelling, (International Perspectives on the Teaching and Learning of Mathematical Modelling 1, ICTMA 14), Springer, 2011.

[17] Jonathan Borwein, David Bailey. Mathematics by Experiment: Plausible Reasoning in the 21st Century, A K Peters, 2004.

[18] Jonathan Borwein, David Bailey. Experimental Mathematics in Action, A K Peters, 2007.

[19] Jonathan Borwein, David Bailey, Ronald Girgensohn. Experimentation in Mathematics (Computional Paths to Discovery), A K Peters, 2004.

[20] Jonathan Borwein, Keith Devlin. The Computer as Crucible - An Introduction to Experimental Mathematics, A K Peters, 2008.

[21] Jonathan Borwein. The Experimental Mathematician: The Pleasure of Discovery and the Role of Proof, International Journal of Computers for Mathematical Learning, 10(2), 75-108, 2005.

[22] Jonathan Borwein. Aesthetics for the Working Mathematician, Queens University Symposium on Beauty and the Mathematical Beast: Mathematics and Aesthetics, 2001.

[23] Margaret Brown, Peter Brown, Tamara Bibby. "I would rather die": reasons by 16-year-olds for not continuing their study of mathematics, Research in Mathematics Education, 10(1), 3-18, 2008.

[24] Bruno Buchberger. Should Students Learn Integration Rules?, ACM SIGSAM Bulletin, 24(1), 10-17, 1990.

[25] B. Buchberger, C. Dupre, T. Jebelean, F. Kriftner, K. Nakagawa, D. Vasaru, W. Windsteiger. The Theorema Project: A Progress Report, Symbolic Computation and Automated Reasoning, Proceedings of CALCULEMUS 2000, Symposium on 
the Integration of Symbolic Computation and Mechanized Reasoning (szerk.: M. Kerber, M. Kohlhase), 98-113, A K Peters, Natick, Massachusetts, St. Andrews.

[26] C. Neményi Eszter, Somfai Zsuzsa. A matematika tantárgy helyzete és fejlesztési feladatai, A tanulás és tanítás helyzete, A tanulás és tanítás helyzete, Oktatáskutató és Fejlesztő Intézet, 2004.

www .ofi.hu/tudastar/tantargyak-helyzete/matematika-tantargy

[27] Cabri

www.cabri.com

[28] Olivia M. Carducci. The Wolfram Demonstrations Project, MAA Focus, 28(1), 8-9, 2009.

[29] Michelle Cirillo. Ten things to consider when teaching proof, Mathematics Teacher, 103(4), 251-257, 2009.

[30] Judita Cofman. Einblicke in die Geschichte der Mathematik I (Aufgaben und Materialen für die Sekundarstufe I), Spektrum Akademischer Verlag Heidelberg, Berlin, 1999.

[31] Judita Cofman. Einblicke in die Geschichte der Mathematik II (Aufgaben und Materialen für die Sekundarstufe II und das Lehramtsstudium), Spektrum Akademischer Verlag Heidelberg, Berlin, 2001.

[32] Judita Cofman. What to Solve? (Problems and Suggestions for Young Mathematicians), Oxford University Press, New York, 1994.

[33] Judita Cofman. Numbers and Shapes Revisited (More Problems for Young Mathematicians), Oxford University Press, New York, 1995.

[34] Gábor Czédli. The number of rectangular islands by means of distributive lattices, European Journal of Combinatorics 30(1), 208-215, 2009.

[35] Gábor Czédli, András P. Huhn, E. Tamás Schmidt. Weakly independent subsets in lattices, Algebra Universalis, 20, 194-196, 1985.

[36] Gábor Czédli, Miklós Hartmann, E. Tamás Schmidt. CD-independent subsets in distributive lattices, Publicationes Mathematicae Debrecen, 74(1-2), 127-134, 2009 .

[37] Gábor Czédli, E. Tamás Schmidt. CDW-independent subsets in distributive lattices, Acta Sci. Math., 75(1-2), 49-53, 2009.

[38] Csermely Péter, Fodor István, Eva Joly, Lámfalussy Sándor (szerk.). Szárny és Teher - Ajánlás a nevelés-oktatás rendszerének újjáépitésére és a korrupció megfékezésére, Bölcsek Tanácsa Alapítvány, Budapest, 2009. 
[39] Developing Quality in Mathematics Education - DQME www .dqme2.eu

[40] Tim Deignan. Enquiry-Based Learning: perspectives on practice, Teaching in Higher Education, 14(1), 13-28, 2009.

[41] Dózsa Mónika. Készüljünk a kompetenciamérésre!, Szövegértés és matematika, 4. évfolyam, Maxim Kiadó, Szeged, 2010.

[42] Saber Elaydi. An Introduction to Difference Equations, Springer, 2005.

[43] Euklidesz

matek.fazekas.hu/euklides/hun/euklides.htm

[44] Euler 3D

www .mozaik.info.hu/Homepage/Mozaportal/MPeuler3d.php

[45] Az Európai Parlament és a Tanács ajánlása az egész életen át tartó tanuláshoz szükséges kulcskompetenciákról (2006/962/EK), Az Európai Unió Hivatalos Lapja 394/10. (2006.12.18.)

eur-lex.europa.eu

[46] Scott Fallstrom, Maron I. Walter. Using Geometer's Sketchpad to Explore, Conjecture, and Enjoy, International Journal of Computers for Mathematical Learning, 14(2), 183-194, 2009.

[47] Efraim Fischbein. Intuition and proof, Mathematics Education I., Major themes in education (szerk.: Alan J. Bishop), Routladge, 78-97, 2010.

[48] Felnőttképzési törvény, 2001. évi CI. törvény a felnőttképzésről http://net.jogtar.hu/jr/gen/hjegy_doc.cgi?docid=A0100101. TV

[49] Stephan Földes, Navin M. Singhi. On Instantaneous Codes, Journal of Combinatorics, Information \& System Sciences 31, 307-316, 2006.

[50] Földes Petra (szerk.) Élő matematika - Hogyan válhatnak hasznossá és használhatóvá a matematikai ismeretek - Beszélgetés Vancsó Ödön kutatóval, Új Pedagógiai Szemle, 133-140, 2002.

[51] Doug French, Charlie Stripp (editors). 'Are You Sure?' Learning about Proof, The Mathematical Association, 1999.

[52] Hans Freudenthal. Mathematik als pädagogische Aufgabe, Ernst Klett Verlag, Stuttgart, 1973.

[53] Furdek Attila. Új utak a matematika tanításában (1), A matematika tanítása, 15(4), 3-6, 2007. 
[54] Furdek Attila. Új utak a matematika tanításában (2), A matematika tanítása, 16(1), 13-16, 2008.

[55] Furdek Attila. Új utak a matematika tanításában (3), A matematika tanítása, 16(2), 9-14, 2008.

[56] Furdek Attila. Új utak a matematika tanitásában (4), A matematika tanítása, 16(3), 7-12, 2008.

[57] Furdek Attila. Új utak a matematika tanításában (5), A matematika tanítása, 16(4), 14-20, 2008.

[58] Anthony Gardiner. Discovering Mathematics (The Art of Investigation), Clarendon Press, Oxford, 1987.

[59] Geogebra.

www.geogebra.org

[60] Geometer's Sketchpad.

www .dynamicgeometry.com

[61] Gordon Gyôri János, Halmos Mária, Munkácsy Katalin, Pálfalvi Józsefné. A matematikatanítás mestersége - Mestertanárok a matematikatanításról, Gondolat Kiadó, Budapest, 2007.

[62] Doug Gould, Denise A. Schmidt. Trigonometry comes alive through digital storytelling, Mathematics Teacher, 104(4), 297-301, 2010.

[63] Fatih Gürsul, Hafize Keser. The effects of online and face to face problem based learning environments in mathematics education on student's academic achievement, Procedia - Social and Behavioral Sciences, 1(1), 2817-2824, 2009.

[64] GrafEq.

www . peda.com/grafeq

[65] Graph.

www . padowan.dk/graph

[66] Halász Gábor. Elôszó, A kompetencia. Kihívások és értelmezések (szerk.: Demeter Kinga), Országos Közoktatási Intézet, Budapest 2006.

[67] G. H. Hardy. Mathematical proof, Mind, 38(149), 1-25, 1928.

[68] Amanda Hawkins, Nathelie Sinclair. Explorations with Sketchpad in Topogeometry, International Journal of Computers for Mathematical Learning, 13(1), 71-82, 2008.

[69] Humán Erőforrás Operatív Program - HEFOP www .hefop.hu 
[70] Eszter K. Horváth, Zoltán Németh, Gabriella Pluhár. The number of triangular islands on a triangular grid, Periodica Mathematica Hungarica, 58(1), 25-34, 2009 .

[71] Eszter K. Horváth, Gábor Horváth, Zoltán Németh, Csaba Szabó. The number of square islands on a rectangular sea, Acta Sci. Math., 76(1-2), 35-48, 2010.

[72] Eszter K. Horváth, Attila Máder, Andreja Tepavčević. One-dimensional Czédlitype Islands, The College Mathematical Journal, 42(5), 374-378, 2011.

[73] Eszter K. Horváth, Branimir Šešelja, Andreja Tepavčević: Cardinality of height function's range in case of maximally many rectangular islands - computed by cuts, Central European Journal of Mathematics, submitted.

[74] Eszter K. Horváth, Branimir Šešelja, Andreja Tepavčević, Cut approach to islands in rectangular fuzzy relations, Fuzzy Sets and Systems 161(24), 3114-3126, 2010 .

[75] Paul Hoffman. A Prímember - Erdôs Pál kalandjai a matematika végtelenjében, Scolar Kiadó, Budapest, 1999.

[76] John Horgan. The death of proof, Scientific American, 1993(10), 92-103, 1993.

[77] Tarja-Riitta Hurme, Sanna Järvelä. Students' Activity in Computer-supported Collaborative Problem Solving in Mathematics, International Journal of Computers for Mathematical Learning, 10(1), 49-73, 2005.

[78] Art Johnson. Preparing for Formal Proofs in Geometry, Mathematics Teacher, 103(4), 291-297, 2009.

[79] Gwendolyn J. Johnson, Deisse R. Thompson, Sharon L. Senk. Proof-Related Reasoning in High School Textbooks, Mathematics Teacher, 103(6), 411-417, 2010.

[80] Katz Sándor. Hogyan változott meg az iskola feladata? Észrevételek, javaslatok, Szárny és Teher: A magyar oktatás helyzetének elemzése - háttéranyag, 40-44, Bölcsek Tanácsa Alapítvány, Budapest, 2009.

[81] Katz Sándor. Kompetenciák, kiemelt területek - Matematikatanitás, Szárny és Teher: A magyar oktatás helyzetének elemzése - háttéranyag, 68-75, Bölcsek Tanácsa Alapítvány, Budapest, 2009.

[82] Dr. Kántor Sándorné. A PISA és az ahhoz hasonló típusú feladatok megoldásának tapasztalatairól, A matematika tanítása, 16(1), 3-12, 2008.

[83] Bart Van Kerkhove, Jean Paul Van Bendegem. Pi on Earth, or Mathematics in the Real World, Erkenntnis, 68(3), 421-435, 2008. 
[84] Dr. Kis-Tóth Lajos. Digitális kompetenciák fejlesztése a tanártovábbképzésben, IX. eLearning fórum www.elearningforum.hu/data/forum9/pdf/Kis_Toth_Lajos_II.pdf

[85] Kerettanterv. www .nefmi.gov.hu/kozoktatas/tantervek/kerettantervek

[86] Zoltán Kovács, Róbert Vajda. Interactive Web Portals in Mathematics, Teaching Mathematics and Computer Science 1(2), 347-361, 2003.

[87] Zoltán Kovács. WMI2: Interactive Mathematics on the Web, Teaching Mathematics and Computer Science 5(2), 393-405, 2007.

[88] Steven G. Krantz. The Proof Is in the Pudding: The Changing Nature of Mathematical Proof, Springer, 2010.

[89] Laczkovich Miklós. Sejtés és bizonyitás, Typotex, Budapest, 1998.

[90] Lakatos Imre. Bizonyitások és cáfolatok, Typotex, Budapest, 1998.

[91] Learning and Educating through Modelling and Applications Project http://lema-project.hu

[92] Zsolt Lengvárszky. The minimum cardinality of maximal systems of rectangular islands, European Journal of Combinatorics, 30(1), 216-219, 2009.

[93] Zsolt Lengvárszky. The size of maximal system of square islands, European Journal of Combinatorics, 30(4), 889-892, 2009.

[94] Zsolt Lengvárszky. Notes on triangular islands, Acta Sci. Math., 75, 369-376, 2009.

[95] Zsolt Lengvárszky, Péter Pál Pach. A note on rectangular islands: the continuous case, Acta Sci. Math., 77, 27-34, 2011.

[96] Lénárd Ferenc. A problémamegoldó gondolkodás, Akadémiai Kiadó, Budapest, 1964.

[97] Leanne A. Lineares, Phil R. Smith. Proof mapping, Mathematics Teacher, 103(4), 259-265, 2009.

[98] Lovász László. Egységes tudomány-e a matematika?, Természet Világa Matematika Különszám, 44-48, TIT, Budapest, 1998.

[99] Paolo Mancosu. Explanation in Mathematics, Stanford Encyclopedia of Philosophy, 2008.

plato.stanford.edu/entries/mathematics-explanation 
[100] Maróti Lászlóné. Kompetencia alapú feladatgyújtemény matematikából 5. évfolyam, Maxim Kiadó, Szeged, 2010.

[101] Maróti Lászlóné, Soós Edit. Kompetencia alapú feladatgyújtemény matematikából 8. évfolyam, Maxim Kiadó, Szeged, 2010.

[102] Maus Pál, Vancsó Ödön. Egy európai uniós projekt a matematikaoktatás megújitásáért, A matematika tanítása, 17(2), 3-9, 2009.

[103] Günther Mayrhofer, Susanne Saminger, Wolfgang Windsteiger. CreaComp: Experimental Formal Mathematics for the Classroom, Symbolic Computation and Education, World Scientific Publishing Co. Pte. Ltd., 94-115, 2007.

[104] Attila Máder. Heads or Tails Gambling - What Can Be Learned about Probability?, Teaching Mathematics and Computer Science, 6(1), 15-41, 2008.

[105] Máder Attila. Néhány zavart okozó fogalmi pontatlanság a középiskolai matematikában, A matematika tanítása, 16(3), 13-17, 2008.

[106] Máder Attila. „Mindenki ír, és senki nem olvas.” - Felmérés néhány matematikai „folyóirat” olvasottságáról, A matematika tanítása, 16(5), 19-25, 2008.

[107] Máder Attila. A „specmat” 40 éve a Ságváriban I., A matematika tanítása, 17(4), 13-21, 2009.

[108] Máder Attila. A „specmat” 40 éve a Ságváriban II., A matematika tanítása, $\mathbf{1 7}(5), 17-27,2009$.

[109] Máder Attila. A kétoldali közelités, összeszámlálás módszerének alkalmazása az algebra, a számelmélet, a geometria, az analizis és a kombinatorika tanitásában, kézirat

[110] Attila Máder, Róbert Vajda. Elementary Approaches to the Teaching of the Combinatorial Problem of Rectangular Islands, International Journal of Computers for Mathematical Learning, 15(3), 267-281, 2010.

[111] Attila Máder, Géza Makay. The maximum number of rectangular islands, The Teaching of Mathematics, 14(1), 31-44, 2011.

[112] Attila Máder. The Use of Experimental Mathematics in the Classroom, Interesting Mathematical Problems in Sciences and Everyday Life 2011.

www .model.u-szeged.hu

[113] Joyce Malyn-Smith. Power Users of Technology, UN Chronicle 2004(2), 51-60. www.un.org/wcm/content/site/chronicle

[114] Maria Alessandra Mariotti. Justifying and proving in the Cabri Environment, International Journal of Computers for Mathematical Learning, 6(3), 257-281, 2001 . 
[115] NEFMI.

www.oh.gov.hu/erettsegi_vizsgak

[116] Metropol, 2011. január 27.

[117] Molnár István. Some thoughts on a student survey, Teaching Mathematics and Computer Science, 8(1), 41-59, 2010.

[118] Nádori Péter oldala.

www . math.bme.hu/ nandori/Virtual_lab/stat/applets

[119] Mogens Niss. Measuring Student Knowledge and Skills (A New Framework for Assessment), Investigation into Assessment in Mathematics Education, 1-104, Kluwer Academic Publishers, 1993.

[120] Kimberly O. Muller. How Technology can promote the learning of proof, Mathematics Teacher, 103(6), 437-441, 2010.

[121] Nemzeti Alaptanterv. 202/2007 Kormányrendelet a Nemzeti alaptanterv kiadásáról, bevezetésérôl és alkalmazásáról szóló 243/2003. kormányrendelet módosításáról

http://net.jogtar.hu/jr/gen/hjegy_doc.cgi?docid=A0700202.KOR

[122] Nagy József. XXI. Század és nevelés, Osiris Kiadó, Budapest, 2000.

[123] Kwok Chi Ng. Replacing Face-to-Face Tutorials by Synchronous Online Technologies: Challenges and pedagogical implications, The International Review of Research in Open and Distance Learning, 8(1), 1-15, 2007.

[124] The On-Line Encyclopedia of Integer Sequences http: //oeis .org

[125] Orosz Gyula. Számítógépes valószinúségszámítási játékok tárgyalása Markovláncok segítségével, Módszertani Lapok, Matematika, 1(1), 24-30, 1994.

[126] Összefoglaló feladtgyújtemény matematikából, Nemzeti Tankönyvkiadó, Budapest, 1999.

[127] P. Veres Ildikó, Víghné Tisótzki Tünde. Készüljünk a kompetenciamérésre!, Szövegértés és matematika, 10. évfolyam, Maxim Kiadó, Szeged, 2010.

[128] P. Veres Ildikó, Veres Pál. Készüljünk a kompetenciamérésre!, Szövegértés és matematika, 8. évfolyam, Maxim Kiadó, Szeged, 2010.

[129] Péter Pál Pach, Gabriella Pluhár, András Pongrácz, Csaba Szabó. The possible number of islands on the sea, Journal of Mathematical Analysis and Applications, 375(1), 8-13, 2011. 
[130] Palotás Zoltán. Tanulás, tanulási környezet és a minôség összefüggései, Oktatáskutató és Fejlesztő Intézet, Budapest, 2009.

[131] Pálfalvi Józsefné. A mestertanárok elbeszélései nyomán támadt gondolataim az elmúlt fél évszázad megújítási törekvéseirôl a magyar matematikatanitásban, A matematika tanítása, 15(3), 9-16, 2007.

[132] Henri Picciotto. Why I use interactive whiteboards?, Mathematics Teacher 104(4), 250-253, 2010.

[133] Gabriella Pluhár. The number of brick islands by means of distributive lattices, Acta Sci. Math., 75, 3-11, 2010.

[134] Poly.

www . peda.com/poly

[135] Pólya György. A gondolkodás iskolája, Bibliotheca, Budapest, 1957.

[136] Pólya György. A problémamegoldás iskolája I.-II., Tankönyvkiadó, Budapest, 1967, 1968.

[137] Pólya György. Indukció és analógia - A matematikai gondolkodás múvészete I., Gondolat, Budapest, 1988.

[138] Pólya György. A plauzíbilis következtetés - A matematikai gondolkodás múvészete II., Gondolat, Budapest, 1988.

[139] Marc Prensky. Digital Natives, Digital Immigrants, On the Horizon, NCB University Press, 9(5-6), 2001.

[140] Prievara Tibor. Na de ki is az a digitális bennszülött? Tanárblog. http: //tanarblog.hu

[141] Réti Mónika. Hogyan változott meg az iskola feladata? Mennyiben terjedt el az árnyékoktatás?, Szárny és Teher: A magyar oktatás helyzetének elemzése - háttéranyag, 17-21, Bölcsek Tanácsa Alapítvány, Budapest, 2009.

[142] Jason Rosenhouse. The Monty Hall Problem - The remarkable story of math's most contentious brain teaser, Univesity Press, Oxford, 2009.

[143] Statistical Indicators Benchmarking the Information Society - SIBIS GPS 2002. Digital literacy among European youth, ww. .sibis-eu.org/statistics/data/7-61.htm

[144] Byron Spice. CMU's Simon reflects on how computers will continue to shape the world, Pittsburg Post-Gazette, October 16, 2000.

[145] Richard Rowland Skemp. A matematikatanulás pszichológiája, Edge 2000, Budapest, 2005. 
[146] Ságvári Bence. Az IT generáció, Nemzeti Ifjúsági Információs és Dokumentációs Adattár www .mobilitas.hu/niida

[147] Somfai Zsuzsa. A matematikatanitás helyzete a középiskolában - A 2003-as obszervációs felmérés tapasztalatai, A tanulás és tanítás helyzete, Oktatáskutató és Fejlesztő Intézet, 2004.

www .ofi.hu/tudastar/tantargyak-helyzete/matematikatanitas

[148] Somfai Zsuzsa. A matematika tantárgy helyzete a felsô tagozaton és a középiskolában, Oktatáskutató és Fejlesztő Intézet, Új Pedagógiai Szemle, 2012(12), 99-115.

www .ofi.hu/tudastar/matematika-tantargy

[149] Soós Edit, Maróti Lászlóné. Kompetencia alapú feladatgyújtemény matematikából 6. évfolyam Maxim Kiadó, Szeged, 2010.

[150] Soós Edit, Maróti Lászlóné. Kompetencia alapú feladatgyújtemény matematikából 7. évfolyam Maxim Kiadó, Szeged, 2010.

[151] Henrik Kragh Sørensen. What's experimental about experimental mathematics? www .experimentalmath.info/papers/sorenson-expm.pdf

[152] Rudolf Straesser. Cabri-Geometere: Does Dynamic Geometry Software (DGS) Change Geometry and its Teaching and Learning?, International Journal of Computers for Mathematical Learning 6(3), 319-333, 2009.

[153] Szalay Balázs. A matematikai kompetencia változása, Szárny és Teher: A magyar oktatás helyzetének elemzése - háttéranyag, 63-67, Bölcsek Tanácsa Alapítvány, Budapest, 2009.

[154] Szendrei János. A matematikatanitás korszerúsitése, Az eredményesebb matematikatanításért, Országos Pedagógiai Intézet, 1977.

[155] Szilágyi Imréné. Kompetenciák, kiemelt területek - A kisiskolások oktatásának legfontosabb változásai (fóbb feszültségpontok), Szárny és Teher: A magyar oktatás helyzetének elemzése - háttéranyag, 63-67, Bölcsek Tanácsa Alapítvány, Budapest, 2009.

[156] David Tall. The Psychology of Advanced Mathematical Thinking, Advanced Mathematical Thinking, 3-21, Kluwer Holland, 1991.

[157] Totik Vilmos. Lehetetlen, Természet Világa Matematika Különszám, 86-93, TIT, Budapest, 1998.

[158] Vancsó Ödön, Hodossy Attila. Matematikai modellezés - nyitott feladatok és az értékelés, Mérei Ferenc Fơvárosi Pedagógiai és Pályaválasztási Tanácsadó Intézet, www.fovpi.hu/data/cms65909/9_Matematikai_modellezes_Vancso_Hodossy_0925.pdf 
[159] Vancsó Ödön. A matematikai modellezés nehézségei egy 2009-es OKTV feladat kapcsán, A matematika tanítása, 17(4), 30-34, 2009.

[160] Vári Péter, Bánfi Ilona, Felvégi Emese, Krolopp Judit, Rózsa Csaba, Szalay Balázs. A PISA 2000 vizsgálatról, Új Pedagógiai Szemle, 2001(12), 31-44.

[161] Vass Vilmos. A kompetencia fogalmának értelmezése, A kompetencia. Kihívások és értelmezések (szerk.: Demeter Kinga), Országos Közoktatási Intézet, Budapest 2006.

[162] Zarádi Zoltán. A hálózati tanulás és az IKT az európai oktatási rendszerekben, Új Pedagógiai Szemle, 2003(2), 75-82.

www .ofi.hu/tudastar/zarandy-zoltan-halozati-090617

[163] Doron Zeilberger. Theorems for a Price: Tomorrow's Semi-Rigorous Mathematical Culture, The mathamatical intelligencer 16(4), 11-14, 1993.

[164] Raymond Louis Wilder. The Nature of Mathematical Proof, The Americal Mathematical Monthly, 51, 309-323, 1944.

[165] H. Wu. The Role of Open-Ended Problems in Mathematics Education, Journal of Mathematical Behavior, 13(1), 115-128, 2004.

[166] WebMathematics Interactive wmi .math.u-szeged.hu

[167] S. Wolfram. The Mathematica Book. Wolfram Media Inc. Champaign, Illinois, USA. Cambridge University Press, 1999.

www. wolfram.com

[168] www.wolfram.com/products/player

[169] www.demonstrations.wolfram.com 